
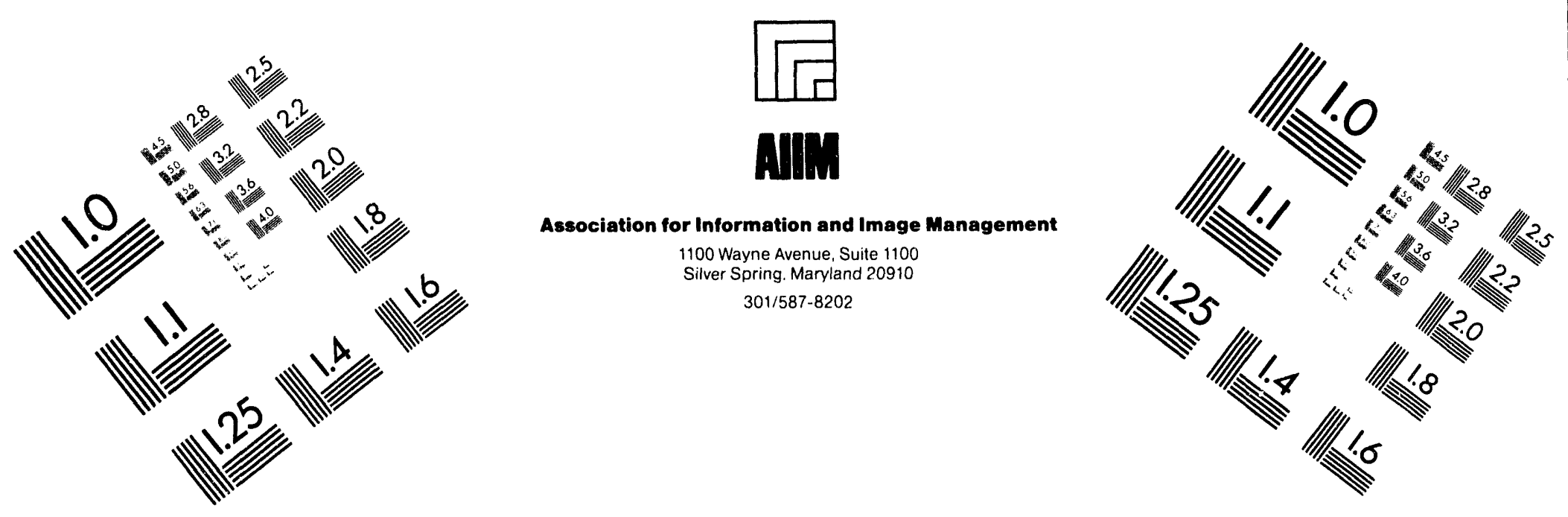

\title{
Centimeter
}

|

Inches
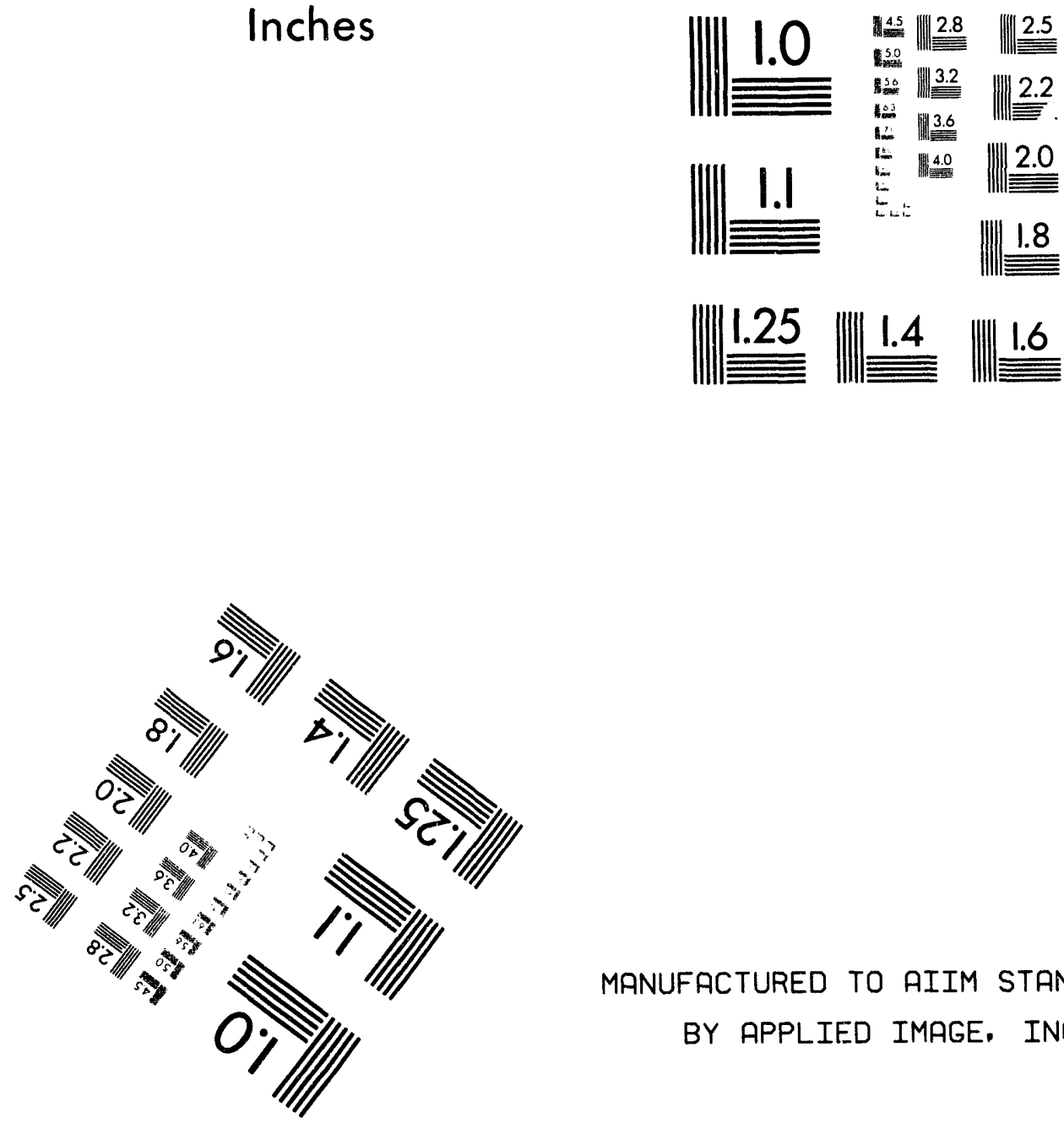

MANUFACTURED TO AIIM STANDARDS

BY APPLIED IMAGE, INC.

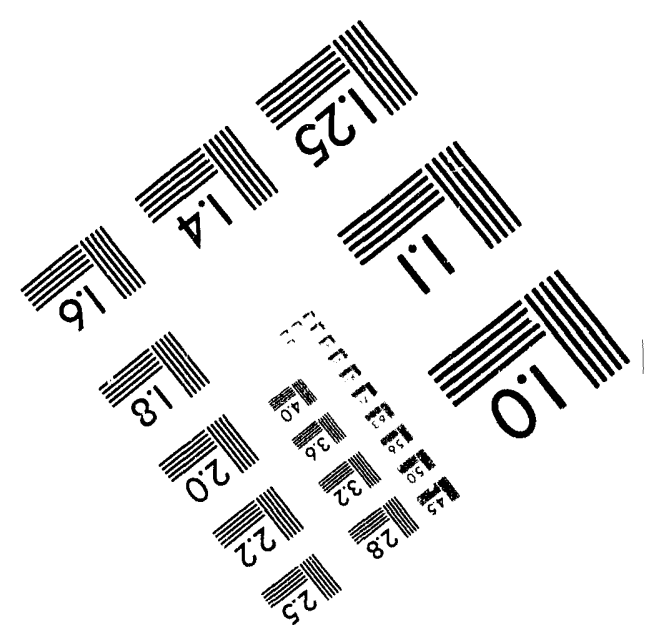



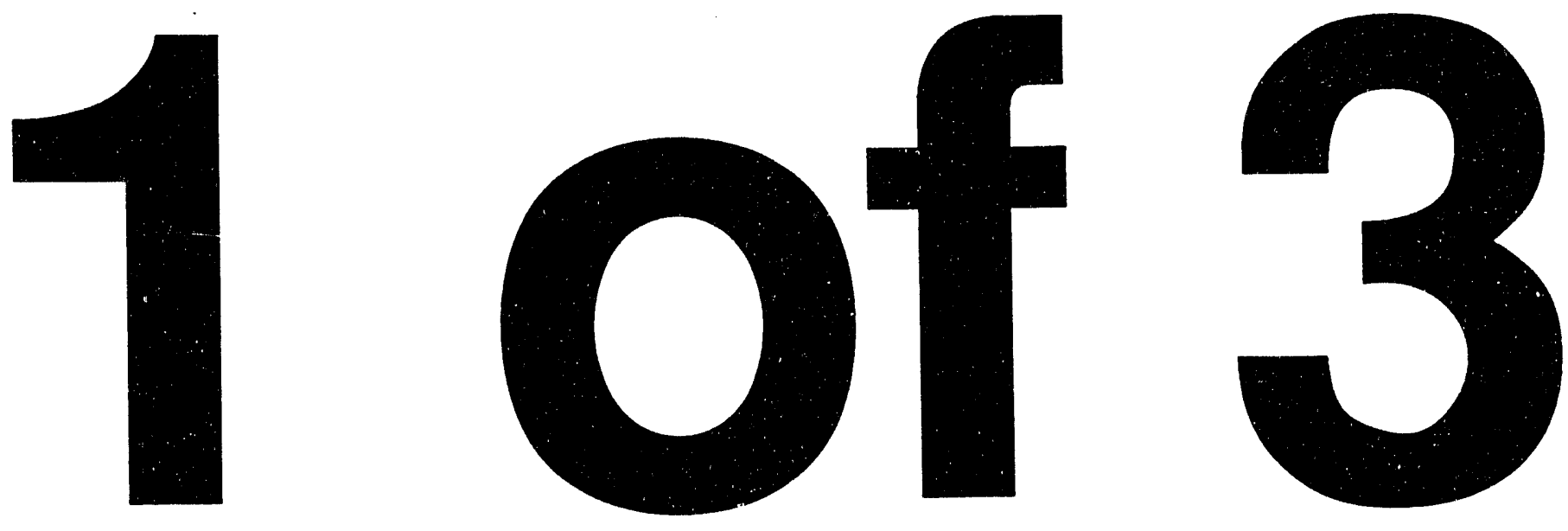


\section{Site Environmental Report}

Prepared for

U.S. Department of Energy

Fernald Field Office

Contract DE - AC05 - 92OR21972

Prepared by

Environmental Protection Department

Fernald Environmental Restoration Management Corporation

June 1994

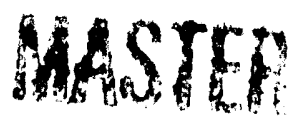


Notice This report was prepared as an account of work sponsored by an agency of the United States government. Neither the United States government or any agency thereof, nor any of their employees, nor any of its contractors, subcontractors nor their employees, make any warranty, expressed or implied, or assume any legal liability or responsibility for the accuracy, completeness, or usefulness of any information, apparatus, product, or process disclosed, or represent that its use would not infringe privately owned rights. Reference herein to any specific commercial product, process, or service by trade name, manufacturer or otherwise, does not necessarily constitute or imply its endorsement, recommendation, or favoring by the United States government or any agency thereof. The views and opinions of authors expressed herein do not necessarily state or reflect those of the United States government or any agency thereof, or Fernald Environmental Restoration Management Corporation, its affiliates or its parent companies.

This report has been reproduced from the best available copy.

Available to DOE and DOE contractors from:

The Office of Scientific and Technical information

P.O. Box 62

Oak Ridge, TN 37831

Prices available from (615) 576-8401, FTS 626-8401.

Available to the public from:

The National Technical Information Service

U.S. Department of Commerce

5285 Port Royal Road

Springfield, VA 22161

Printed Copy Price: A11

Microfiche Price: A01

(7)

This document was reproduced on recycled and iecyclable paper 


\section{Table of Contents}

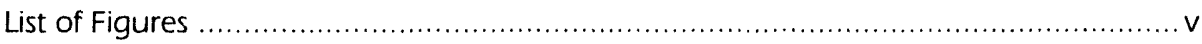

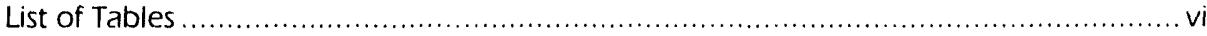

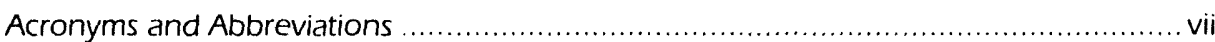

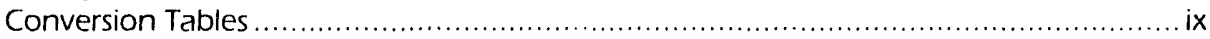

$\begin{array}{lc}\text { Executive Summary } & \text { xi }\end{array}$

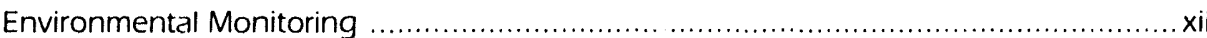

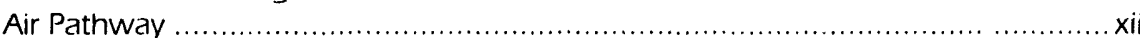

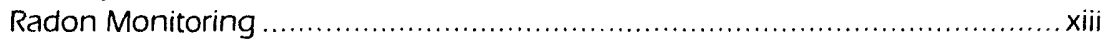

Liquid Pathway: Effluent and Surface Water ........................................ xiii

Liquid Pathway: Groundwater ........................................................... xiv

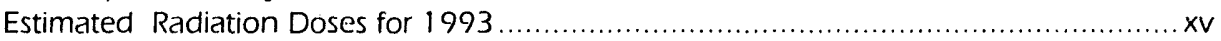

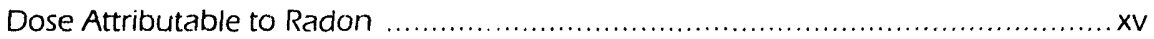

Chapter 1 - Introduction to the Site 1

The Fernald Site Mission: Environmental Compliance and Restoration........................ 2

An Overview of Former Production Operations ...................................... 4

Handling and Storing Radioactive and Hazardous Materials ........................... 4

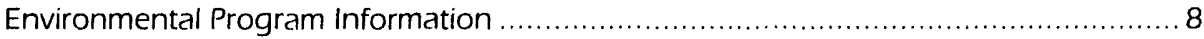

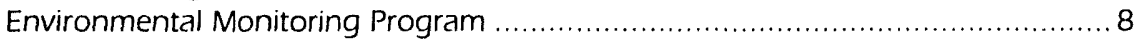

Meteorology Program ................................................................ 9

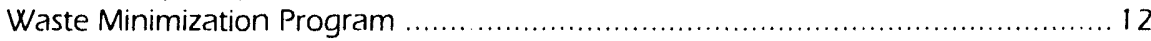

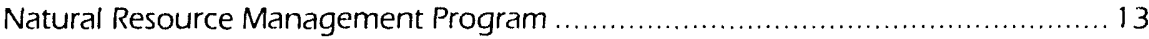

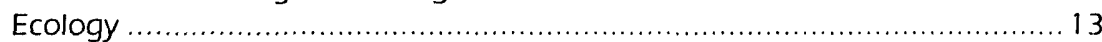

Threatened and Endangered Species ........................................ 14

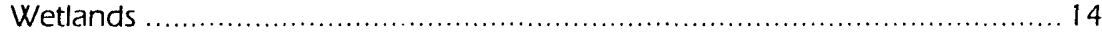

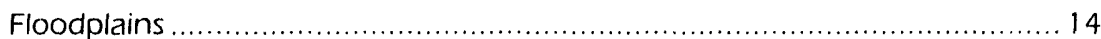

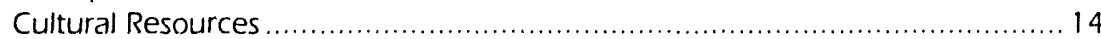

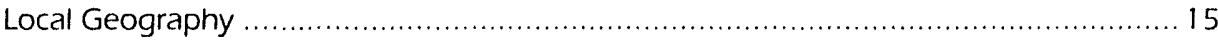

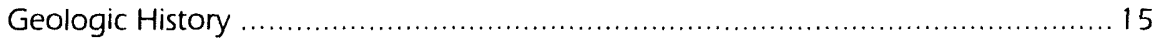

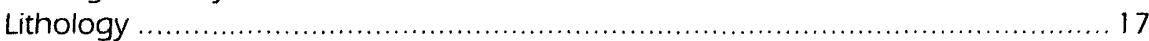

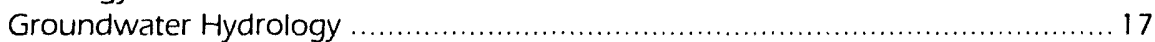

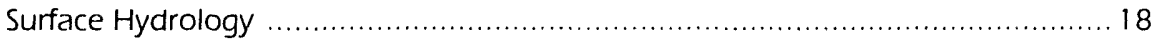

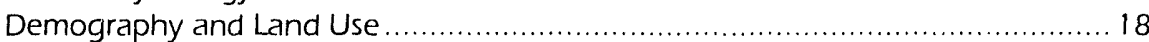

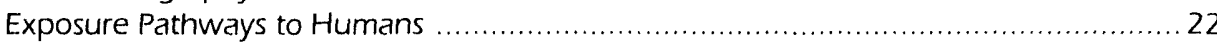

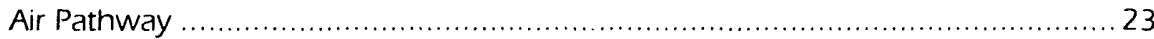

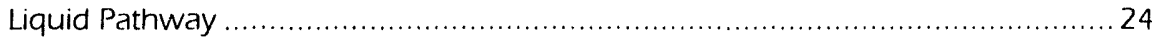

Environmental Standards and Guidelines ................................................ 25

Chapter 2 - Fundamentals of Radiation and Health Hazards 29

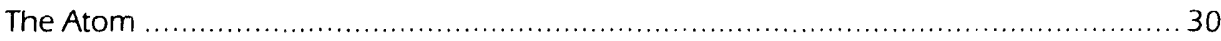

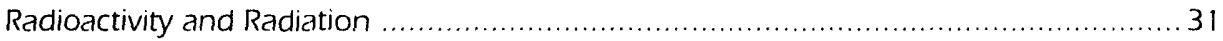

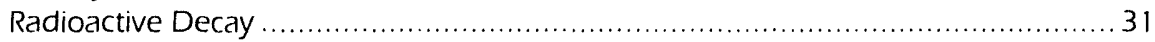

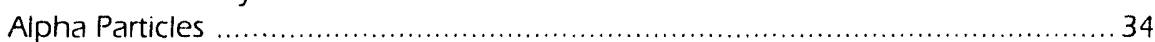

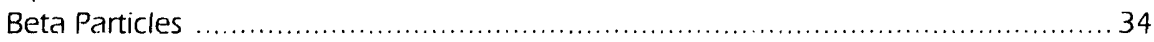

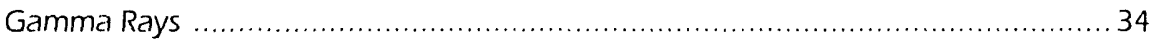

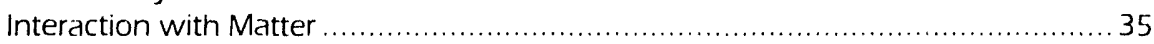

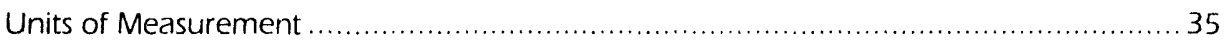

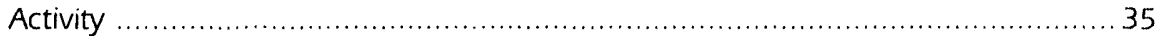

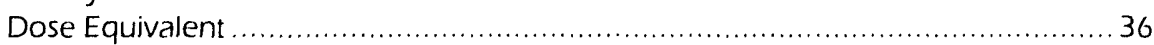

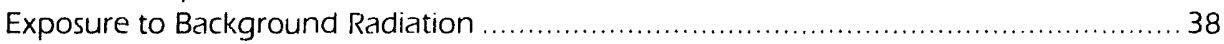

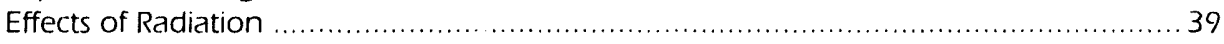

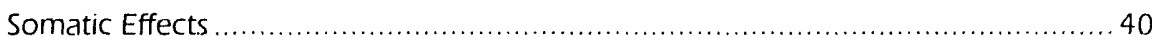

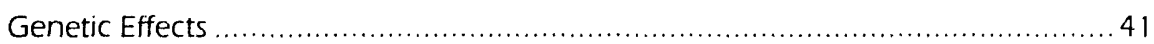

Health Hazards at the Fernald Site ......................................................... 42

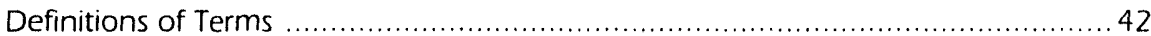


Chapter 3 - Environmental Compliance Summary 45

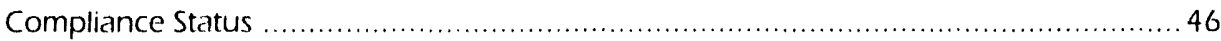

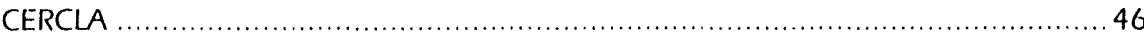

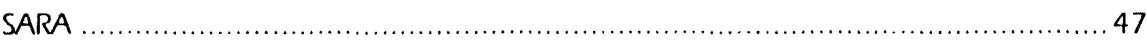

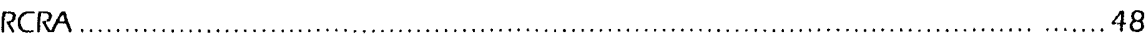

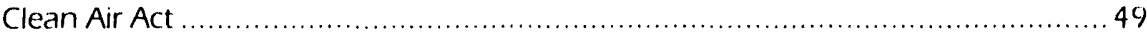

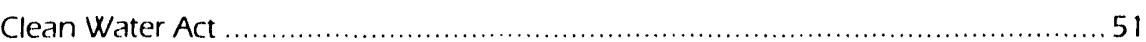

NPDES Effluent Regulation ........................................................... 51

NPDES Stormwater Regulation ................................................ 51

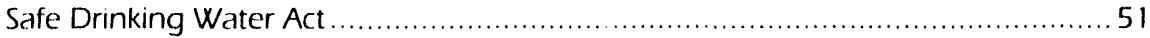

Toxic Substances Control Act ......................................................... 53

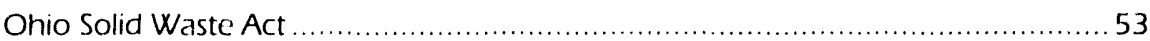

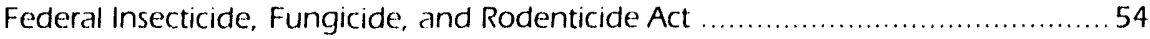

National Environmental Policy Act ...................................................... 54

Endangered Species Act ................................................................ 55

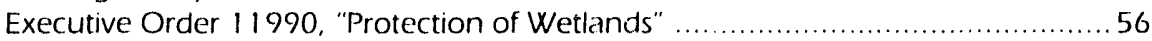

Executive Order 11988, "Floodplain Management" .................................. 56

National Historic Preservation Act ...................................................... 56

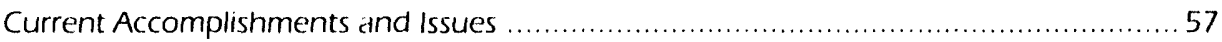

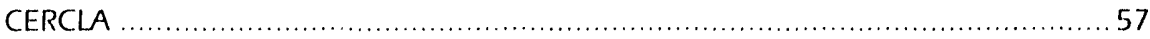

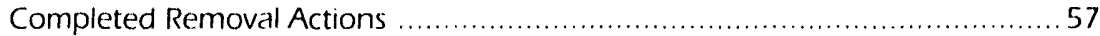

Ongoing Removal Actions ......................................................... 59

Other CERCLA Accomplishments and Issues ................................. 59

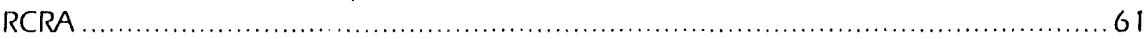

Thorium Management ........................................................... 61

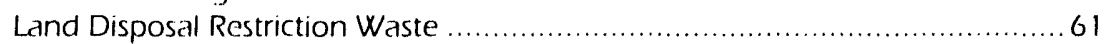

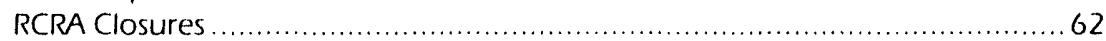

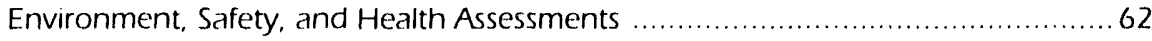

Chapter 4 - Air Pathway Monitoring $\quad 65$

Monitoring for Radioactive Pollutants ....................................................67

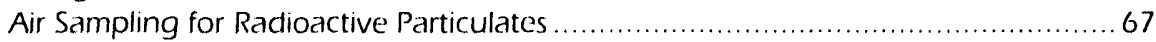

Comparison of Measured and Estimated Emissions ................................... 72

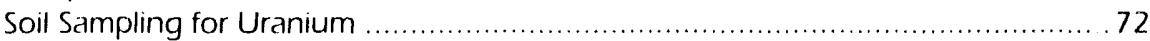

Grass Sampling for Uranium ........................................................... 74

Produce Sampling for Uranium ....................................................... 75

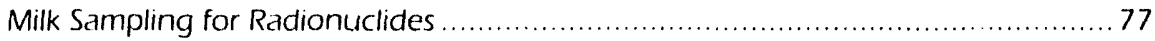

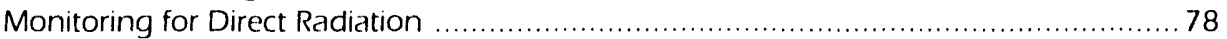

Monitoring for Nonradioactive Pollutants ............................................... 78

Chapter 5 - Liquid Pathway: Effluent and Surface Water Monitoring 81

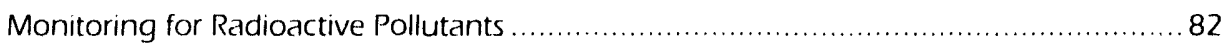

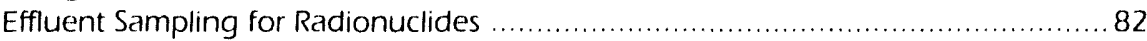

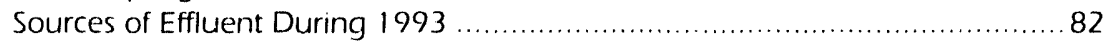

Sarnpling Methodologies ...................................................... 84

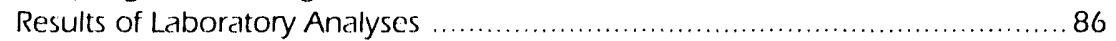

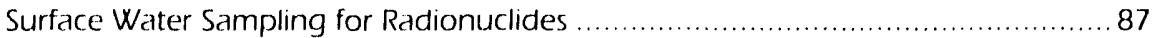

Sampling Methodologies .......................................................... 89

Results of Laboratory Analyses ...................................................... 89

Sediment Sampling for Radionuclides ........................................... 91

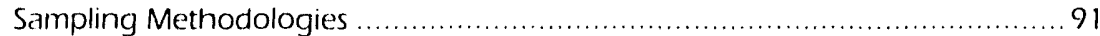

Results of Laboratory Analyses ................................................... 93

Fish Sampling for Uranium ......................................................... 93

Sampling Methodologies ................................................... 93

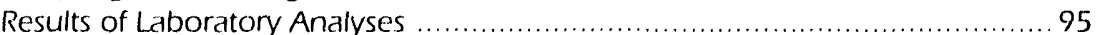

Monitoring for Nonradioactive Pollutants .................................................. 96

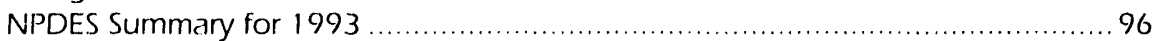


History of Groundwater Monitoring at the Site ............................................. 98

Monitoring for Radioactive Pollutants ....................................................... 99

Private Well Sampling for Uranium ................................................. 99

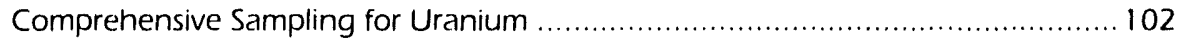

Comprehensive Groundwater Monitoring for Other Radionuclides .................. 105

South Groundwater Contamination Plume ......................................... 105

Monitoring for Nonradioactive Pollutants ................................................ 107

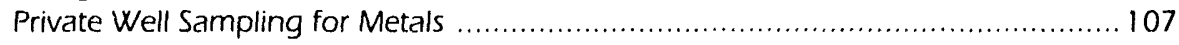

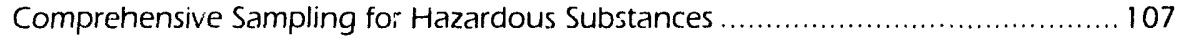

Detections above Primary Standards ......................................... 107

Detections above Secondary Standards ..................................... 114

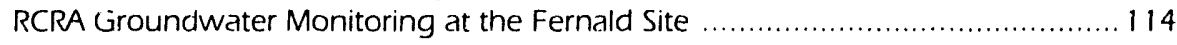

$\begin{array}{ll}\text { Chapter } 7 \text { - Estimated Radiation Doses for } 1993 & 117\end{array}$

Methcdology for Calculating Total Radiation Dose ......................................... 118

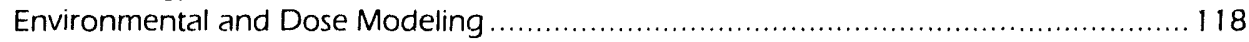

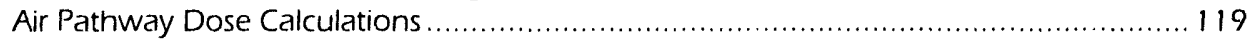

Estimated Doses from Airborne Emissions .............................................. 119

Estimated Dose from Eating Foodstuffs Produced near the Fernald Site .............. 121

Direct Radiation Dose ............................................................. 122

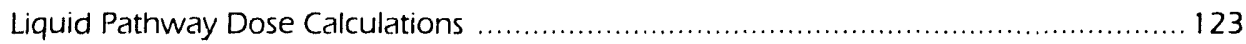

Estimated Dose from Drinking Well Water

in the Area around the Fernald Site ................................................. 123

Estimated Dose from Drinking Great Miami River Water ............................ 123

Estimated Dose from Eating Fish from the Great Miami River .......................... 124

Total of Doses to a Maximally-Exposed Individual ........................................... 124

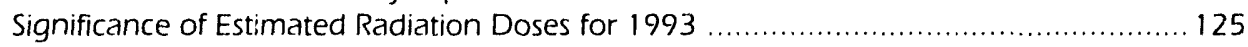

$\begin{array}{ll}\text { Chapter } 8 \text { - The Radon Monitoring Program } & 127\end{array}$

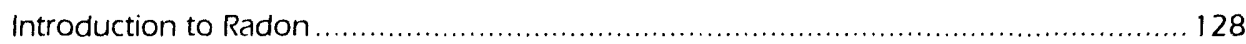

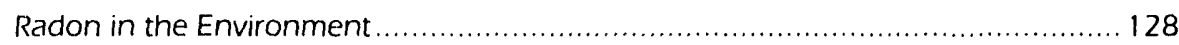

Radon at the Fernald Site .......................................................... 130

Radon Monitoring at the Fernald Site ................................................... 130

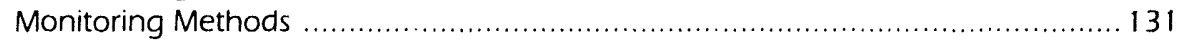

1993 Environmental Radon Monitoring Results ..................................... 135

Estimated Radiation Dose from Radon ................................................. 136,

Control of Radon at the Fernald Site ................................................... 137

Chapter 9 - Quality Assurance for the Environmental Monitoring Program 139

Sitewide CERCLA Quality Assurance Project Plan ............................................ 140

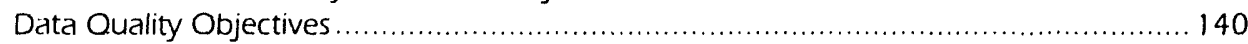

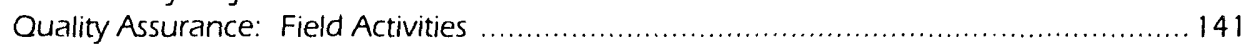

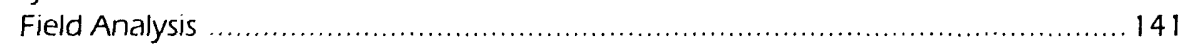

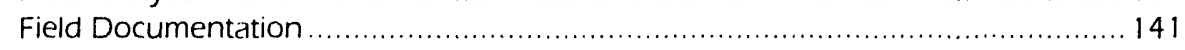

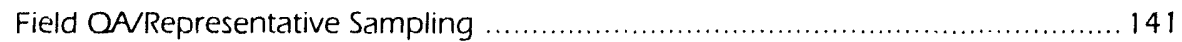

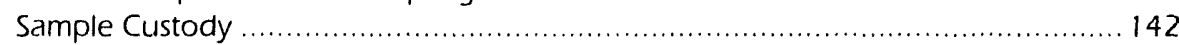

Analytical Laboratory Quality Assurance ................................................. 143

Analytical Methods .................................................................... 143

Analytical Performance .............................................................. 143

Detection of Data Problems and Corrective Action ................................... 144

Independent Evaluations of the Fernald Site Laboratories ............................... 144

DOE's Environmental Measurements Laboratory .................................... 144

USEPA's Discharge Monitoring Report .................................................. 145

Commercial Proficiency Environmental Testing ......................................... 145

Ohio Department of Health Split Samples ........................................ 146

Contract Laboratory Quality Assurance ................................................ 146 
Appendices

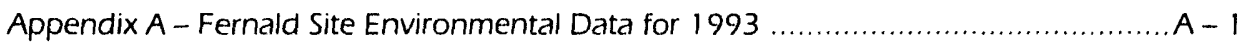

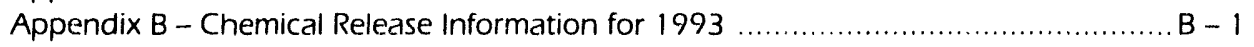

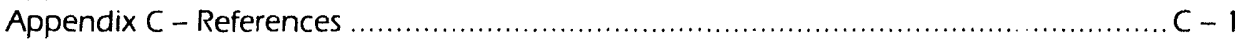

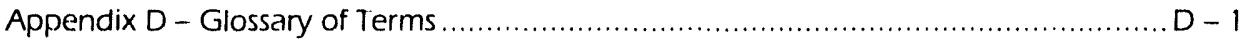




\section{List of Figures}

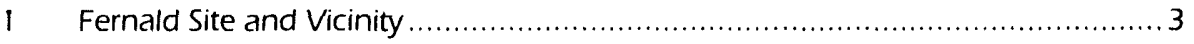

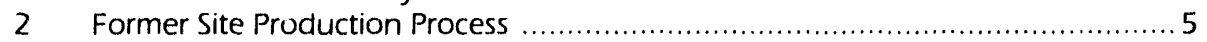

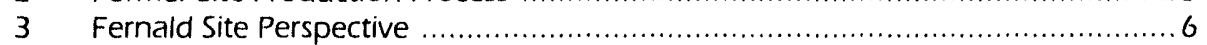

41993 Wind Rose Data, 10 Meter Height .......................................... 10

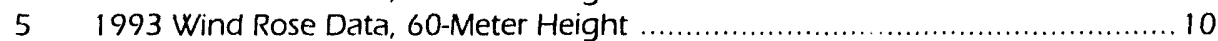

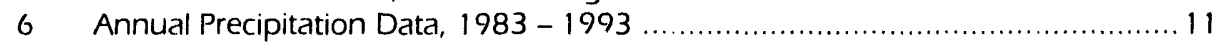

7 Cross-Section of the New Haven Trough, Looking North ........................... 16

8 Buried Valley Aquifer Underlying the Fernald Site and Vicinity ...................... 19

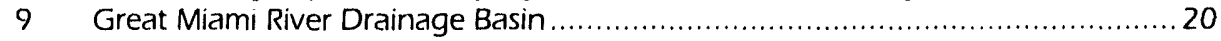

10 Major Communities in Southwestern Ohio ....................................... 21

11 General Air Pathways to Humans ...................................................... 23

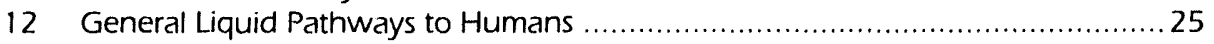

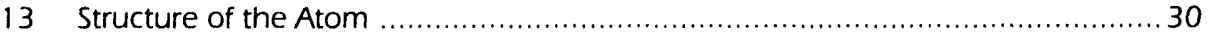

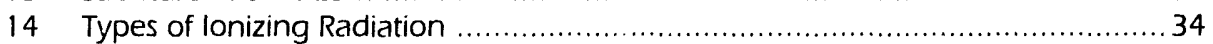

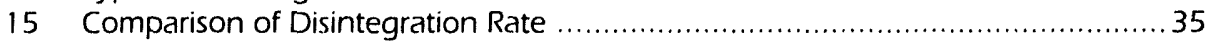

16 Organs Affected by Substances Found at the Fernald Site ......................... 37

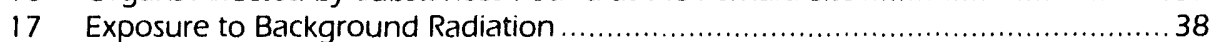

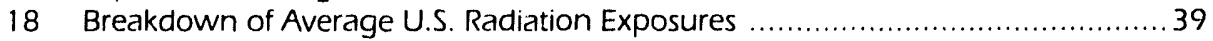

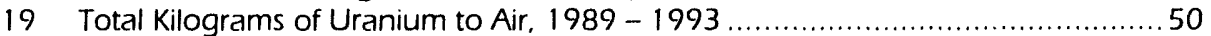

20 NPDES Effluent and Stormwater Monitoring Locations ........................... 52

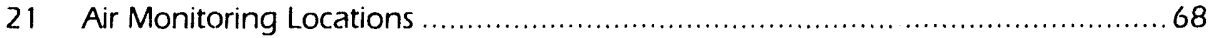

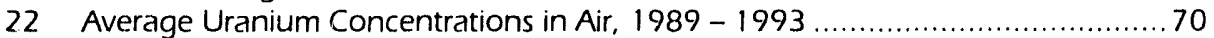

23 Average Thorium-232 Concentrations in Air, $1989-1993 \ldots \ldots \ldots \ldots \ldots \ldots \ldots \ldots . \ldots 1$

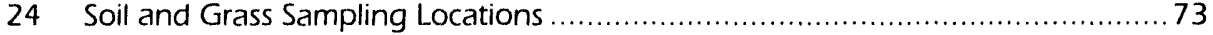

25 Range of Total Uranium Occurring in Surface Soils .................................... 74

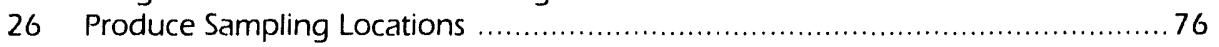

27 Direct Radiation Monitoring Locations ................................................ 79

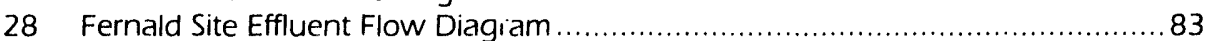

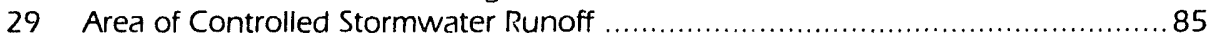

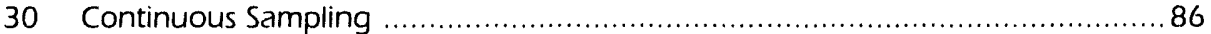

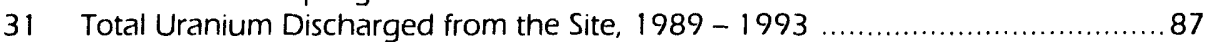

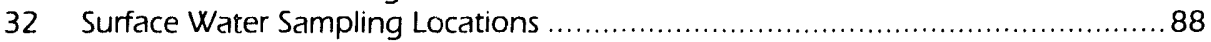

33 Average Uranium Concentrations in Surface Water, $1989-1993 \ldots \ldots \ldots \ldots \ldots . . . . . . .90$

34 Sediment Sampling Locations ...................................................... 92

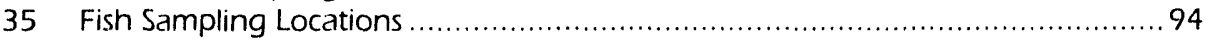

36 Private Well Monitoring Locations ..................................................... 100

37 Average Uranium Concentrations in Private Wells, $1989-1993 \ldots \ldots \ldots \ldots \ldots \ldots \ldots . . . . . .101$

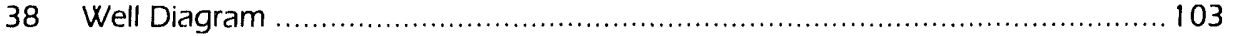

39 Monitoring Well Depths and Screen Locations ...................................... 104

40 South Groundwater Contamination Plume ......................................... 106

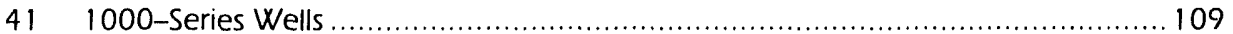

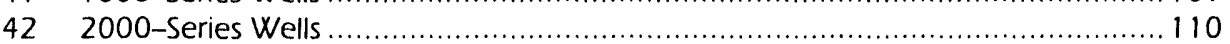

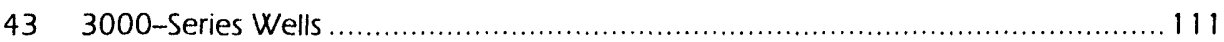

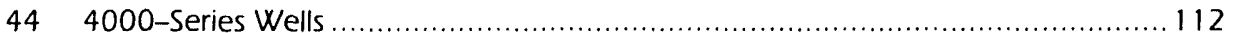

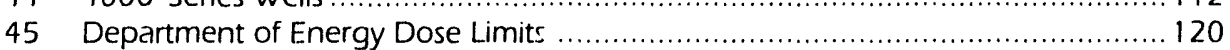

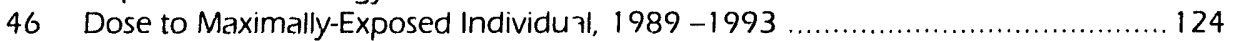

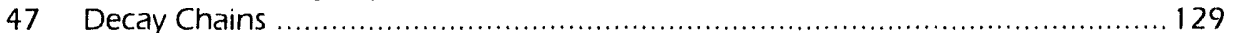

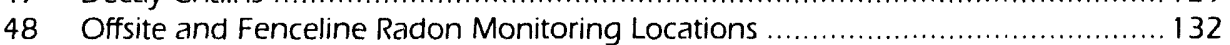

49 Radon Monitoring Locations Near the Silos ...................................... 133

50 Continuous Radon Monitoring Locations .......................................... 134

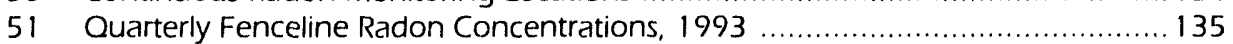

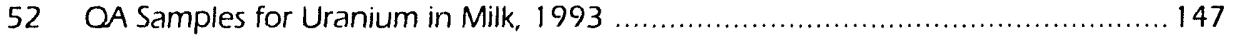




\section{List of Tables}

2

3

4

5

6

6

8

9

10

11

12

13

14

15

16

17

18

Meteorological Data, 1993 A -2

Estimated Population Distribution within $80 \mathrm{~km}$ (50 miles) of the Fernald Site, 1993

Uranium in Air, 1993

Radionuclides in Air, 1993

$A-5$

Comparison of Measured and Estimated Airborne Uranium Concentrations at the Fernald Site Fenceline

Uranium in Grass and Soil, 1993

$A-9$

Uranium in Produce and Soil, 1993

$A-10$

Uranium in Milk, 1993.

$A-12$

Radionuclides in Milk, 1993

$A-13$

Environmental TLD Direct Radiation Measurements, 1993

$A-14$

Radionuclides Discharged to the Great Miami River, 1993

$A-15$

Radionuclides in Surface Water, 1993

$A-16$

Radionuclides in Great Miami River, Paddys Run,

and Storm Sewer Outfall Ditch Sediments, 1993

$A-18$

Uranium Concentrations in Fish from the Great Miami River, 1993 .............. A - 19

NPDES Data, 1993

$A-20$

Uranium in Private Wells, 1993

$A-23$

Comprehensive Groundwater Samples with Uranium Concentrations

above USEPA Proposed Standard, 1993

$A-24$

Metals in Private Wells, 1993

$A-28$

above Primary Drinking Water Standards, 1993

$A-31$

Summary of Radiation Dose

$A-37$

Estimated Airborne Emissions for the Fernald Site, 1993

$A-38$

Radon in Air, 1993

A -39

DOE Quality Assessment Program for Environmental

Radionuclide Analyses Fernald Site Laboratories Performance Results, 1993 ... A - 41

USEPA Quality Assurance Program for Wastewater Analyses

Fernald Site Laboratories Performance Evaluation, 1'/93

A -42

Proficiency Environmental Testing Quality Assurance Program

for Water Analyses, 1993.

$A-43$

Fernald Site - ODH Uranium Sampling Comparison, 1992

A -45 


\title{
Acronyms and Abbreviations
}

\author{
ACA Amended Consent Agreement \\ AEC Atomic Energy Commission \\ AHF Anhydrous Hydrogen Fluoride \\ ALARA As Low As Reasonably Achievable \\ AMS Air Monitoring Station \\ ANSI American National Standards Institute \\ ARAR Applicable or Relevant and Appropriate Requirement \\ ASER Annual Site Environmental Report \\ AWWT Advanced Wastewater Treatment \\ BAT Best Available Technology \\ BDN Bic denitrification Facility \\ BMP Bejt Management Practices \\ BSL Piodenitrification Surge Lagoon \\ CERCLA Comprehensive Environmental Response, Compensation, and Liäbility Act \\ CFR Code of Federal Regulations \\ Ci Curie \\ Co Carbon Monoxide \\ CPID Closure Plan Information and Data \\ CX Categorical Exclusion \\ D\&D Decontamination and Dismantling \\ DCG Derived Concentration Guideline \\ DFO Director's Final Findings and Orders \\ DOE Department of Energy \\ DQO Data Quality Objective \\ EA Environmental Assessment \\ EDE Effective Dose Equivalent \\ EIS Environmental Impact Statement \\ EM Environmental Monitoring \\ EML Environmental Measurements Laboratory \\ ES\&H Environment, Safety, and Health \\ ETS Effluent Treatment System \\ FEMP Fernald Environmental Management Project \\ FERMCO Fernald Environmental Restoration Management Corporation \\ FFA Federal Facility Agreement \\ FFCAct Federal Facility Compliance Act \\ FIFRA Federal Insecticide, Fungicide, and Rodenticide Act \\ FMPC Feed Materials Production Center \\ FONSI Finding of No Significant Impact \\ FS Feasibility Study \\ FS/PP Feasibility Study/Proposed Plan \\ SQAPP Groundwater Quality Assessment Program Plan \\ HSL Hazardous Substances List \\ HWMU Hazardous Waste Management Unit \\ IAWWT Interim Advanced Wastewater Treatment \\ ICRP International Commission on Radiological Protection \\ LDR Land Disposal Restriction \\ MCL Maximum Contaminant Level \\ $\mu \mathbf{C i}$ microcurie \\ mrem millirem \\ NAAOS National Ambient Air Quality Standards \\ NCRP National Council on Radiation Protection and Measurements \\ NEPA National Environmental Policy Act \\ NESHAP National Emission Standards for Hazardous Air Pollutants
}




\begin{tabular}{|c|c|}
\hline NOD & Notice of Deficiency \\
\hline NON & Notice of Noncompliance \\
\hline NOV & Notice of Violation \\
\hline No & Nitrogen Oxide \\
\hline NPDES & National Pollutant Discharge Elimination System \\
\hline NPL & National Priorities List \\
\hline NRC & National Response Center \\
\hline NRC & Nuclear Regulatory Commission \\
\hline NTS & Nevada Test Site \\
\hline OAC & Ohio Administrative Code \\
\hline ODH & Ohio Department of Health \\
\hline OEPA & Ohio Environmental Protection Agency \\
\hline ORNL & Oak Ridge National Laboratory \\
\hline ORO & Oak Ridge Operations \\
\hline OSHA & Occupational Safety and Health Administration \\
\hline ou & Operable Unit \\
\hline PACD & Proposed Amended Consent Decree \\
\hline PCB & Polychlorinated Biphenyls \\
\hline $\mathbf{p C i}$ & picocurie \\
\hline PEIC & Public Environmental Information Center \\
\hline PET & Proficiency Environmental Testing \\
\hline PTI & Permit to Install \\
\hline PTO & Permit to Operate \\
\hline $\mathbf{Q A}$ & Quality Assurance \\
\hline $\mathbf{Q F}$ & Quality Factor \\
\hline RAO & Remedial Action Objective \\
\hline RAWP & Removal Action Work Plan \\
\hline RCRA & Resource Conservation and Recovery Act \\
\hline rem & Roentgen Equivalent Man \\
\hline $\mathbf{R I}$ & Remedial Investigation \\
\hline RI/FS & Remedial Investigation and Feasibility Study \\
\hline ROD & Record of Decision \\
\hline $\mathbf{R M}$ & River Mile \\
\hline $\mathbf{R O}$ & Reportable Quantity \\
\hline SACD & Stipulated Amended Consent Decree \\
\hline SARA & Superfund Amendments and Reauthorization Act \\
\hline sca & Sitewide CERCLA Quality Assurance Project Plan \\
\hline SDWA & Safe Drinking Water Act \\
\hline SER & Site Environmental Report \\
\hline SHPO & State Historic Preservation Officer \\
\hline $\mathrm{SO}_{2}$ & Sulfur Dioxide \\
\hline SPCC & Spill Prevention Control and Countermeasure \\
\hline SSOD & Storm Sewer Outfall Ditch \\
\hline su & Standard Units \\
\hline SWMU & Solid Waste Management Unit \\
\hline SWRB & Stormwater Retention Basin \\
\hline TLD & Thermoluminescent Dosimeter \\
\hline TSCA & Toxic Substances Control Act \\
\hline TSDF & Treatment, Storage, and Disposal Facility \\
\hline UNH & Uranyl Nitrate Hexahydrate \\
\hline USEPA & U.S. Environmental Protection Agency \\
\hline VOC & Volatile Organic Compounds \\
\hline WEMCO & Westinghiouse Environmental Management Company of Ohio \\
\hline WM/PP & Waste Minimization/Pollution Prevention \\
\hline
\end{tabular}




\section{Conversion Tables}

\begin{tabular}{llllll} 
Multiply & By & To Obtain & Multiply & By & To Obtain \\
\hline Length & & & & \\
\hline inches & 2.54 & centimeters $(\mathrm{cm})$ & $\mathrm{cm}$ & 0.394 & inches \\
feet & 0.3048 & meters $(\mathrm{m})$ & $\mathrm{m}$ & 3.281 & feet \\
miles & 1.61 & kilometers $(\mathrm{km})$ & $\mathrm{km}$ & 0.62 & miles
\end{tabular}

\section{Volume}

cubic centimeters $\left(\mathrm{cm}^{3}\right)$ fluid ounces grams (g) kilograms $(\mathrm{kg})$ $\mathrm{mL}$

gallons

q'iarts

cubic feet $\left(\mathrm{ft}^{3}\right)$
1

16.39

29.59

1

1

1,000

3.79

0.95

0.02833

\section{milliliters ( $\mathrm{mL}$ )}

$\mathrm{mL}$

$\mathrm{mL}$

$\mathrm{mL}$ (water)

liter (L) (water)

$$
\text { L. }
$$

L

L

cubic meters $\left(\mathrm{m}^{3}\right)$

miles

\section{Mass}

\begin{tabular}{llllll}
\hline ounces & 28.33 & $\mathrm{~g}$ & $\mathrm{~g}$ & 0.035 & ounces \\
pounds & 455 & $\mathrm{~g}$ & $\mathrm{~g}$ & 0.0022 & pounds \\
pounds & 0.455 & $\mathrm{~kg}$ & $\mathrm{~kg}$ & 2.2 & pounds \\
tons & 0.907 & metric tons & metric tons & 1.1 & tons
\end{tabular}

\section{Activity}

$\begin{array}{llllll}\text { Curies }(\mathrm{Ci}) & 10^{12} & \text { picocuries }(\mathrm{pCi}) & \mathrm{pCi} & 10^{-12} & \mathrm{Ci} \\ \text { Becquerel }(\mathrm{Bq}) & 27.02 & \mathrm{pCi} & \mathrm{pCi} & 0.037 & \mathrm{~Bq} \\ \mathrm{Ci} & 10^{6} & \text { microcurie }(\mu \mathrm{Ci}) & \mu \mathrm{Ci} & 10^{-6} & \mathrm{Ci} \\ \mathrm{pCi} & 0.037 & \mathrm{~Bq} & \mathrm{~Bq} & 27 & \mathrm{pCi}\end{array}$

\section{Dose}

$\begin{array}{llllll}\text { rem } & 1,000 & \text { millirem } \text { (mrem) } & \text { mrem } & 0.001 & \text { rem } \\ \text { Sieverts (SV) } & 100 & \text { rem } & \text { rem } & 0.01 & \text { SV }\end{array}$

For Natural Uranium in Water

$\begin{array}{llllll}\begin{array}{l}\text { micrograms } \\ \text { per liter }(\mu \mathrm{g} / \mathrm{L})\end{array} & 1 & \text { parts per billion }(\mathrm{ppb}) & \mathrm{ppb} & 1 & \mathrm{\mu g} / \mathrm{L} \\ \mu \mathrm{g} / \mathrm{L} & 0.6757 & \mathrm{pCi} / \mathrm{L} & \mathrm{pCi} / \mathrm{L} & 1.48 & \mu \mathrm{g} / \mathrm{L} \\ \begin{array}{l}\text { milligrams } \\ \text { per liter }(\mathrm{mg} / \mathrm{L})\end{array} & 1 & \text { parts per million }(\mathrm{ppm}) & \mathrm{ppm} & 1 & \mathrm{mg} / \mathrm{L} \\ \mathrm{mg} / \mathrm{L} & 675.7 & \mathrm{pCi} / \mathrm{L} & \mathrm{pCi} / \mathrm{L} & 0.00148 & \mathrm{mg} / \mathrm{L} \\ \mathrm{pCi} / \mathrm{L} & 1.48 & \mathrm{ppb} & \mathrm{ppb} & 0.6757 & \mathrm{pCi} / \mathrm{L}\end{array}$

For Natural Uranium in Soil

$\begin{array}{llllll}\mu g / g & 1 & p p m & p p m & 1 & \mu g / g \\ \mu g / g & 0.6757 & p C i / g & p C i / g & 1.48 & \mu g / g \\ p C i / g & 1.48 & p p m & p p m & 0.6757 & p C i / g\end{array}$

\section{For Temperature}

F $\times 9 / 5+32{ }^{\circ} \mathrm{C} \quad{ }^{\circ} \mathrm{C} \quad-32 \times 5 / 9 \quad{ }^{\circ} \mathrm{F}$




\begin{tabular}{lrll} 
Multiple & Decimal Equivalent & Prefix & Symbol \\
\hline $10^{6}$ & $1,000,000$ & mega- & $\mathrm{M}$ \\
$10^{3}$ & 1,000 & kilo- & $\mathrm{k}$ \\
$10^{2}$ & 100 & hecto- & $\mathrm{h}$ \\
10 & 10 & deka- & $\mathrm{da}$ \\
$10^{-1}$ & 0.1 & deci- & $\mathrm{d}$ \\
$10^{-2}$ & 0.01 & renti- & $\mathrm{C}$ \\
$10^{-3}$ & 0.001 & milli- & $\mathrm{m}$ \\
$10^{-6}$ & 0.000001 & micro- & $\mu$ \\
$10^{-9}$ & 0.000000001 & nano- & $\mathrm{n}$ \\
$10^{-12}$ & 0.000000000001 & pico- & $\mathrm{p}$ \\
$10^{-15}$ & 0.000000000000001 & femto- & $\mathrm{f}$ \\
$10^{-18}$ & 0.000000000000000001 & atto- & $\mathrm{a}$
\end{tabular}




\section{Executive Summary}

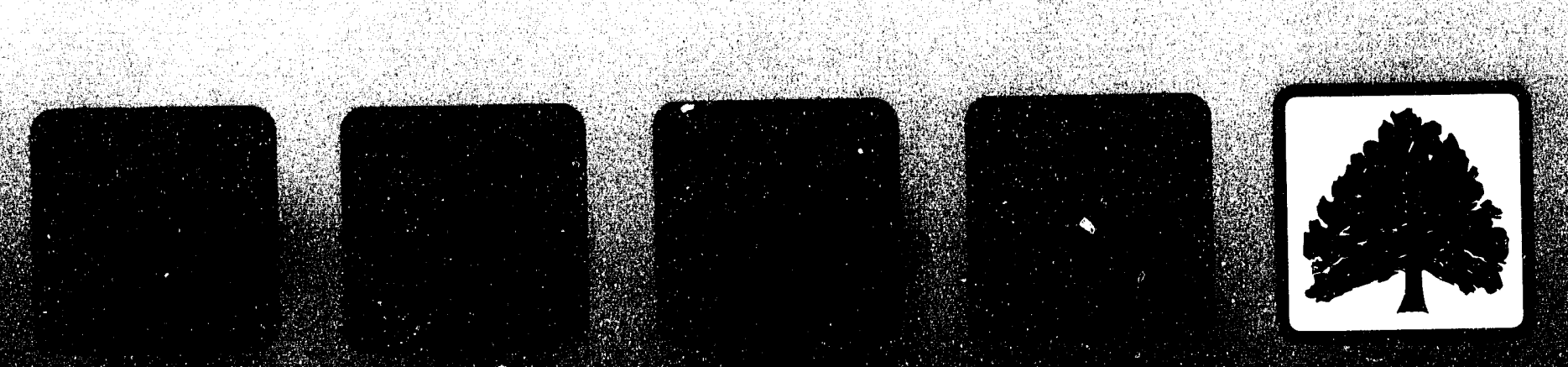




\section{Executive Summary}

The Fernald site is a Department of Energy (DOE) owned facility that produced high-quality uranium metals for military defense for nearly 40 years. DOE suspended production at the site in 1989 and formally ended production in 1991. Although production activities have ceased, the site continues to examine the air and liquid pathways as possible routes through which pollutants from past operations and current remedial activities may leave the site.

The Site Environmental Report (SER) is prepared annually in accordance with DOE Order 5400.1, "Coneral Environmental Protection Program." This 1993 SER provides the general public as well as scientists and engineers with the results from the site's ongoing Environmental Monitoring Program. Also included in this report is information concerning the site's progress toward achieving full compliance with requirements set forth by DOE, U.S. Environmental Protection Agency (USEPA), and Ohio EPA (OEPA).

For some readers, the highlights provided in this Executive Summary may provide sufficient information. Many readers, however, may wish to read more detailed descriptions of the information than those which are presented here. All information presented in this summary is discussed more fully in the main body of this report. 


\section{Environmental Monitoring}

The Fernald site's Environmental Monitoring Program plays a key role in the effort to investigate the effects that years of operation have had on the local environment. Environmental monitoring primarily examines the air and water pathways; other program components address contamination risks associated with cleanup procedures. A summary of air and liquid pathway results is presented below.

\section{Air Pathway}

Monitoring the air pathway incorporates results from not only the air monitoring stations but also from soil, grass, produce, and milk sampling. (Radon is discussed separately below.) Overall, the air monitoring data from 1993 were consistent with data from 1992. While Boiler Plant emissions were higher than in 1992, all emissions were well below permit limits. The increase is attributable to returning the boilers to full service after a coal bunker fire in 1992 limited Boiler Plant operations.

Data collected from fenceline air monitoring stations showed that average concentrations of uranium were all less than $1 \%$ of the DOE standard. Airborne emissions for 1993 were estimated to be $0.21 \mathrm{~kg}(0.46$ pound). This estimate is $9 \%$ lower than the 1992 estimate of $0.23 \mathrm{~kg}(0.51$ pound $)$. Airborne uranium emissions steadily dropped after processing operations were discontinued in 1989, and they have remained relatively constant since 1991 .

Some onsite and nearby offsite soil samples continue to indicate elevated uranium concentrations due to deposition of airborne particles from past operations. One offsite sampling location, which is in the predominant wind direction northeast of the site, had a total uranium concentration of $5.3 \mathrm{pCi} / \mathrm{g}$. A background level for uranium in soil is set at $2.8 \mathrm{pCi} / \mathrm{g}$ for the Fernald area.

The 1993 results from grass sampling indicated that uranium concentrations were higher at the fenceline than at offsite sampling locations. The onsite grass concentrations are better correlated to local airborne uranium concentrations than soil concentrations, which suggests that deposition of uranium is the source of the higher concentrations.

Home-grown sweet corn and tomatoes are two of the major crops sold from roadside stands within $5 \mathrm{~km}$ ( 3 miles) of the site. Local residents also grow and sell beets, potatoes, apples, lettuce, pumpkins, cucumbers, and peppers. Uranium concentrations in produce in 1993 were consistent with previous years' data. Laboratory analyses did not detect any significant differences in uranium concentrations between produce grown near the site $(0-5 \mathrm{~km}$ or $0-3$ miles $)$ and produce grown at distant locations ( $11-42 \mathrm{~km}$ or $7-26$ miles $)$. 
In general, uranium concentrations from the local dairy's milk were comparable to those from a background dairy in Indiana. The data demonstrated that milk from the local dairy is not affected by site emissions.

Measurements of direct radiation indicated that levels were higher with proximity to the K-65 silos. These measurements were consistent with the fact that the silos contain radium and radon gas which contribute to the direct radiation in the vicinity.

\section{Radon Monitoring}

Radon is transported through the air pathway and is, therefore, discussed here. However, radon monitoring results are reported separately in this Site Environmental Report from the air pathway in order to improve the presentation of information and regulations that are unique to radon.

In 1993, the average fenceline radon concentration was $0.63 \pm 0.20 \mathrm{pCi} / \mathrm{L}$. This concentration is greater than the 1992 average concentration of $0.57 \pm 0.29 \mathrm{pCi} / \mathrm{L}$. but it is well below the guideline of $3.0 \mathrm{pCi} / \mathrm{L}$. For comparison, some established average background concentrations range from 0.2 to $0.4 \mathrm{pCi} / \mathrm{L}$.

\section{Liquid Pathway: Effluent and Surface Water}

The effluent and surface water component of the liquid pathway is monitored to determine any impacts from the Fernald site on the Great Miami River and Paddys Run. The Environmental Monitoring Program examines the effluent and surface water results, along with sediment and fish results because they are also part of the liquid pathway.

Approximately $474 \mathrm{~kg}$ ( 1,044 pounds) of uranium were discharged to the Great Miami River during 1993. Of that total, $453 \mathrm{~kg}$ (998 pounds) were from Manhole175 , and $22 \mathrm{~kg}$ (48 pounds) were from South Plume groundwater pumping. Approximately $109 \mathrm{~kg}$ ( 241 pounds) of uranium reached Paddys Run through uncontrolled stormwater runoff during 1993.

The liquid effluent discharged to the Great Miami River resulted in a slightly higher measurement of uranium at the downriver sampling location than the upriver location. However, the downriver concentration was consistent with 1992 sampling results. Paddys Run continued to show effects of stormwater runoff from the site. Although the average uranium concentration at the nearest Paddys Run sampling location was higher than in 1992, it was only $1.7 \%$ of the DOE guideline for drinking water. (That guideline is used for comparison purposes only since there is no established guideline for uranium in surface water.)

Radionuclide concentrations in the Great Miami River and Paddys Run sediments for 1993 were consistent with previous years' data and did not indicate a build-up of radioactive pollutants in the sediment. 
In 1993. fish from three locations along the Great Miami River were sampled for uranium. Results indicated that uranium concentrations were no greater in fish caught downstream of the site's effluent line than in those caught upstream.

The National Pollutant Discharge Elimination System (NPDES) permit specifies sampling locations, sampling and reporting schedules, discharge limits, water quality standards. and other restrictions on the Fernald site's effluents discharged to the Great Miami River and Paddys Run. There were only three violations of NPDES limits at Manhole-175, the final NPDES monitoring point before effluents are discharged to the river. Out of the 4.020 NPDES samples taken at internal and external monitoring locations in 1993. only 11 were not within permit limits.

\section{Liquid Pathway: Groundwater}

The site carefully monitors the groundwater beneath and in the vicinity of the site to identify and track the movement of pollutants which may be present in the Great Miami Aquife: In 1993 the Fernald site routinely sampled 36 private wells for total uranium. Three of these wells, each of which is in an area of known groundwater contamination, had an average uranium concentration above the proposed USEPA standard of $13.5 \mathrm{pCi} / \mathrm{L}(20 \mathrm{ppb})$. These 36 wells were also sampled for several metals. Four wells showed concentrations of lead at or above the Primary Drinking Water Standard as listed for the control of lead. Additionally, as is common for an area with high natural concentrations of iron and manganese, such as the area surrounding the Fernald site, several private wells showed concentrations of these two metals above the USEPA Secondary Drinking Water Standards.

Aside from the private well sampling program, the Fernald site conducts comprehensive groundwater sampling of several site-owned wells. In 1993, the site sampled 454 on- and offsite wells for uranium, and 127 wells showed detections above the proposed USEPA guideline of $13.5 \mathrm{pCi} / \mathrm{L}(20 \mathrm{ppb})$. All of the offsite locations were in the South Groundwater Contamination Plume area. This comprehensive program also sampled those 454 wells for 11 metals and 31 Volatile Organic Compounds that have Primary Drinking Water Standards. Of these 42 constituents, 16 were detected above their primary standards in more than one well. Four other constituents showed single detections above their primary standards. 


\section{Estimated Radiation Dose for 1993}

Scientists calculate potential radiation doses to nearby residents by entering offsite radionuclide concentrations, which are determined through environmental monitoring and sampling, into mathematical models.

In 1993, the hypothetical maximally-exposed individual living nearest the Fernald site, exclusively consuming local foodstuffs and fish, along with drinking water from a well in the Fernald area, could have received a maximum committed effective dose of approximately $1.0 \mathrm{mrem}$. (This dose is exclusive of the dose received from radon.) This dose can be compared to the limit of 100 mrem for all pathways (also exclusive of radon) that was established by the International Commission on Radiological Protection and adopted by DOE.

\section{Dose Attributable to Radon}

Just as radon monitoring results are discussed separately from the air pathway monitoring results, the dose attributable to radon is discussed separately from the rest of the estimated radiation dose for 1993.

As discussed above, the radon concentration measured at the site fenceline in 1993 was $0.63 \pm 0.20 \mathrm{pCi} / \mathrm{L}$. The effective dose calculated from this concentration was estimated to be $454 \mathrm{mrem}$, and it includes the annual dose received from average background levels of radon (approximately $2(0)$ mrem per year). 


\section{Introduction to the Site}

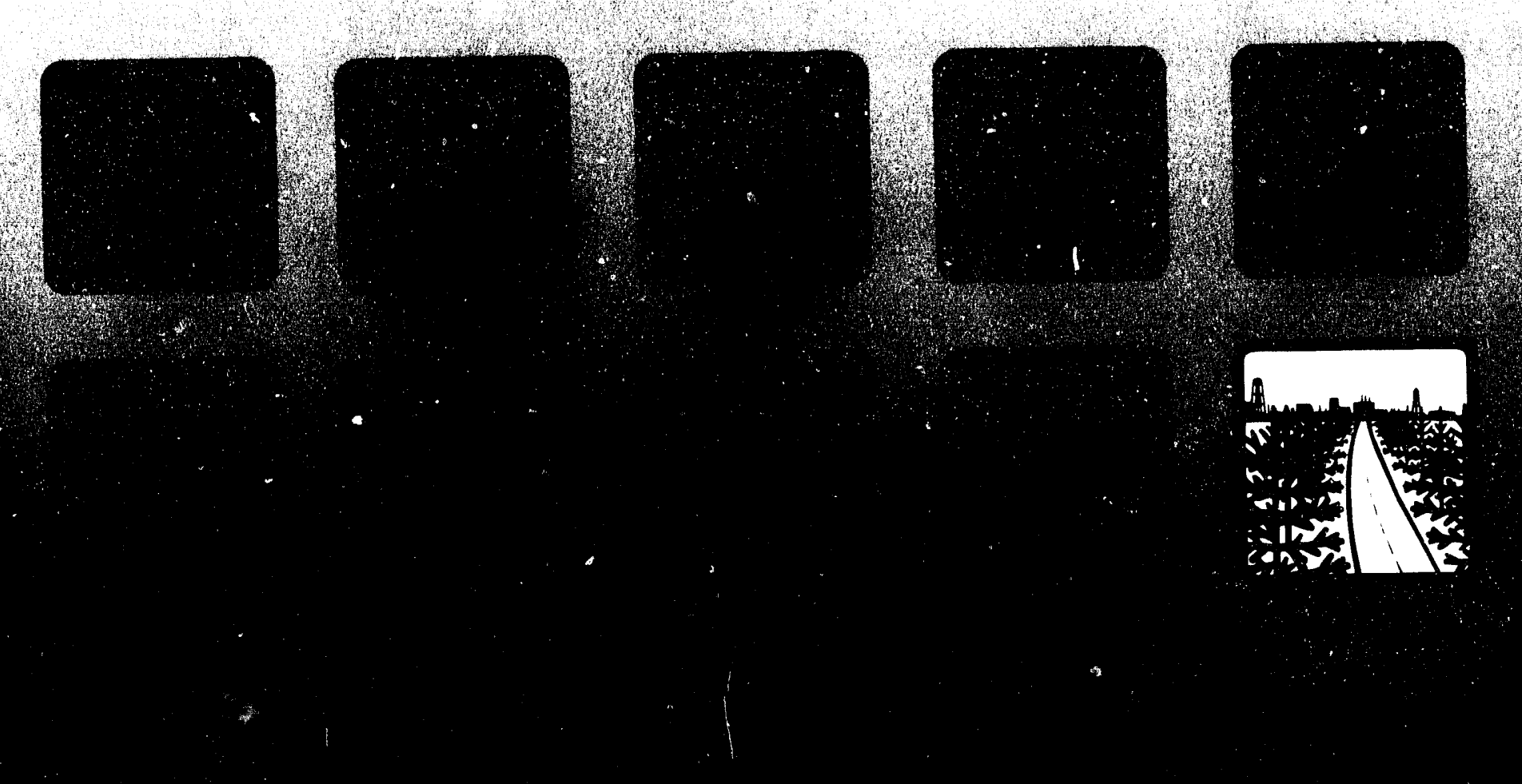




\section{Introduction to the Site}

Today, the Fernald site, which is owned by the Department of Energy (DOE), focuses extensively on environmental restoration. Because it was formerly a uranium metals processing facility, scientists closely investigate the site and surrounding areas for contamination. Remedial techniques are then developed accordingly.

This Fernald Site Environmental Report (SER) documents the results of the Environmental Monitoring Program for calendar year 1993. In accordance with DOE Order 5400.1, "General Environmental Protection Program," the information in the 1993 SER is current from January 1. 1993, through December 31. 1993.' In order to put the material presented in this report into perspective, Chapter One contains the following introductory sections:

- The Fernald Site Mission: Environmental Compliance and Restoration, a historical overview of the site's former operations and its current cleanup mission leading to current site activities;

- Environmental Program Information, a description of site activities aimed at monitoring and maintaining environmental quality;

- Local Geography, an introduction to the physical, ecological, and human characteristics of the area;

- Exposure Pathways to Humans, an examination of the physical and biological surroundings as possible routes for contaminants to reach local communities; and

- Environmental Standards and Guidelines, a description of the various standards with which the Fernald site must comply to protect the local environment. 


\section{The Fernald Site Mission: Environmental Compliance and Restoration}

In recent years, the mission at the Fernald site has become one of environmental compliance and restoration. However, when the site was established in the early 1950s, its primary mission was to produce uranium metal.

Shortly after the end of World War II, the United States recognized a need for new facilities to produce uranium metal in support of defense activities. Existing facilities, developed for the war effort, were neither economical to operate nor able to meet increasing demands. The Atomic Energy Commission (AEC) required an increase in the quality and quantity of uranium metal as well as improvements in the control and safety of production operations.

After evaluating several sites, the government selected a 425-hectare (1,050-acre) area, about $27 \mathrm{~km}$ ( 17 miles) northwest of downtown Cincinnati, Ohio, as the site for a new production facility (see Figure 1). This facility was sited just north of Fernald, Ohio, a small farming community. Ground was broken on May 16, 1951, and the first uranium derby was produced at the site's Pilot Plant on October 11, 1951. The major portion of construction was completed by 1954 .

In general, the relative importance and corresponding funding of the former production and environmental activities reflect the course of U.S. Defense history from the end of World War II until today. Uranium-metal production reached a peak during the height of the Cold War in the 1950s and 1960s. During the late 1970)s, funding for production and supporting organizations, including environmental monitoring, was significantly reduced, subsequently reducing supporting activities. Production accelerated again in the carly 1980s when the United States increased Defense spending. By the late 1980s, however, ar increasing demand for environmental accountability, combined with a decreasing demand for uranium metal at other DOE facilities, influenced DOE to change the site's mission from uranium production to environmental restoration.

Production was suspended in July 1989. In October 1990), DOE transferred management responsibility for the site from its Defense Programs organization to the Office of Environmental Restoration and Waste Management. In February 1991, DOE announced its intention to formally end the production mission and submitted a closure plan to Congress, which became effective in June 1991. 


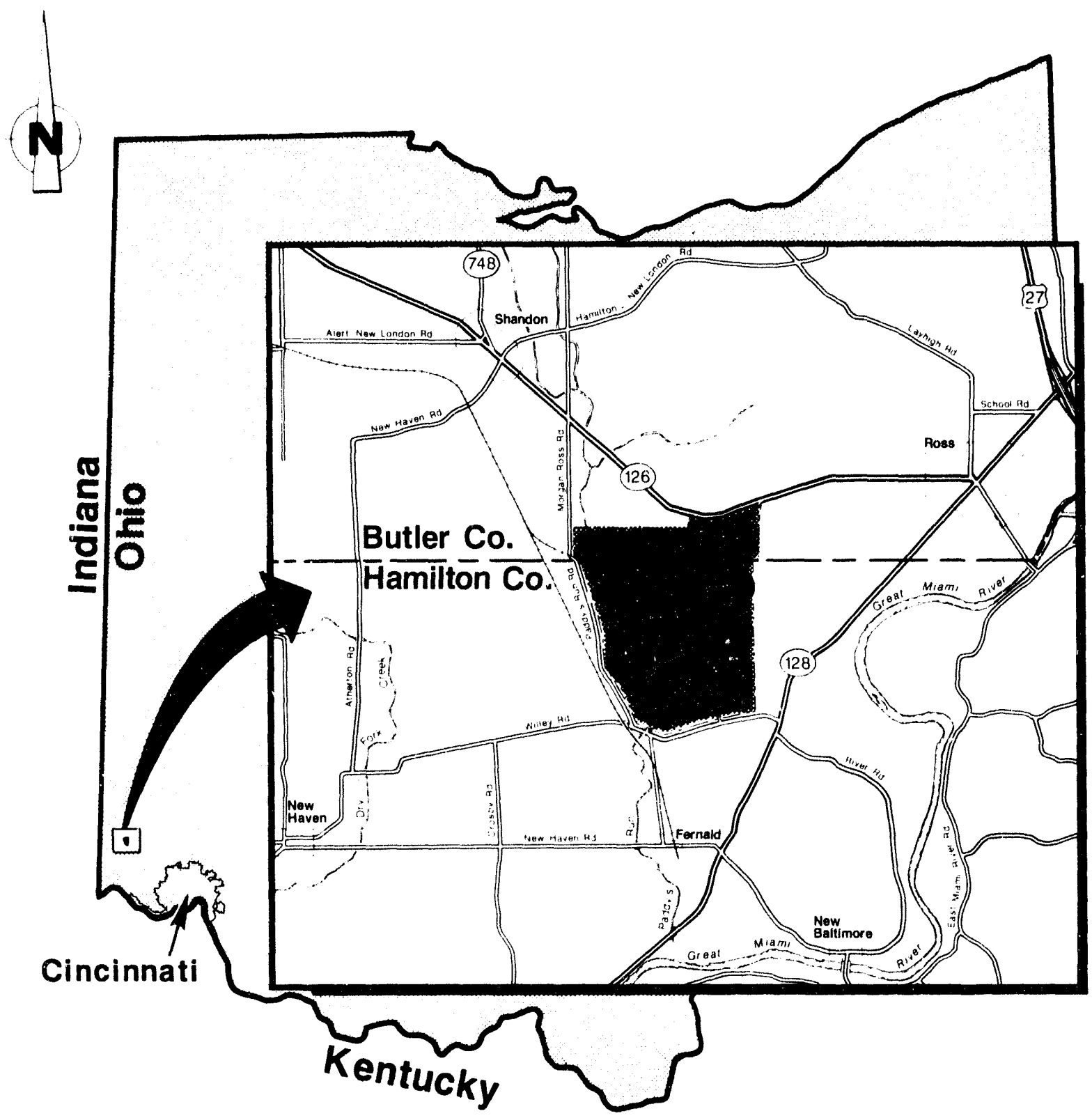

The Fernald Site covers about 425 hectares (1,050 acres). 


\section{An Overview of Former Production Operations}

Although prod.uction at the Fernald site ended in 1989, a brief overview of the production process will provide the reader with a perspective on the ongoing Environmental Monitoring Program and other environmental investigations. The major steps in the production process are highlighted in Figure 2. A variety of materials were used in the process, including many that were received from other DOE sites. In fact, materials such as floor sweepings, dust collector residues, and production residues were recycled in order to recover as much uranium as possible.

\section{Depieted and Enriched Uranium}

Most of the uranium processed in more recent years at the site was depleted in the uranium-235 isotope; that is, it contained a smaller percentage of uranium-235 than does naturally occurring uranium - less than $0.71 \%$. (Isotopes are discussed in Chapter Two, "Fundamentals of Radiation and Health Hazards.") For many years, much of the uranium processed was slightly enriched $-0.71 \%$ to $2 \%$ uranium-235
The first production steps involved chemical processing that ended with an intermediate product commonly called "green salt" (uranium tetrafluoride, $U_{4}$ ). The green salt was then blended with magnesium-metal granules, placed in a closed reduction pot, and heated in furnaces in Plant 5 (see Figure 3). The product of this operation was uranium metal called a "derby."

Some derbies were sent directly to other DOE sites, while the site remelted the remainder, along with uranium scrap metal recovered from earlier

production, and poured them into graphite molds to form ingots. Ingots varied in weight, size, and shape according to how they were used at this and other DOE sites. Machining of these ingots occurred in plants 6 and 9, after which the billets (machined ingots) were shipped to other DOE sites, principally the Savannath River Site in South Carolina and the Hanford Site in Richland, Washington.

\section{Handling and Storing Radioactive and Hazardous Materials}

Although the Fernald site no longer produces uranium metal, it continues to store materials once used here and at other DOE sites. Some of the radioactive and hazardous materials that were handled or stored onsite during 1993 include the following:

\section{Radioactive}

- Magnesium fluoride $\left(\mathrm{MgF}_{2}\right)$ contaminated with uranium,

- Pitchblende ore residues containing radium stored in the K-65 silos,

- Radioactive materials in the waste pits,

- Scrap metal contaminated with uranium compounds,

- Thorium and thorium compounds stored within the production area,

- Uranium compounds, and

- Uranium metal. 


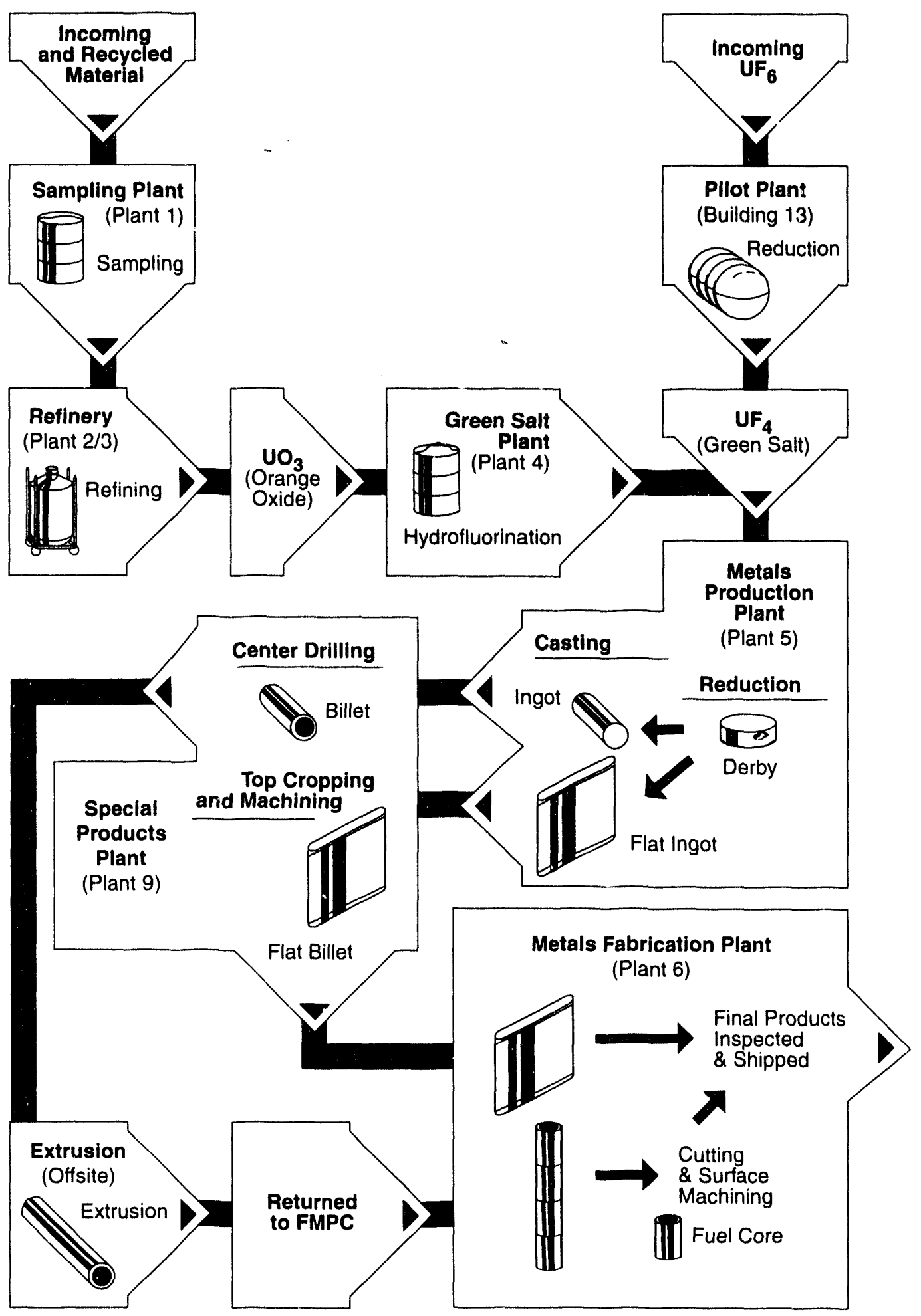




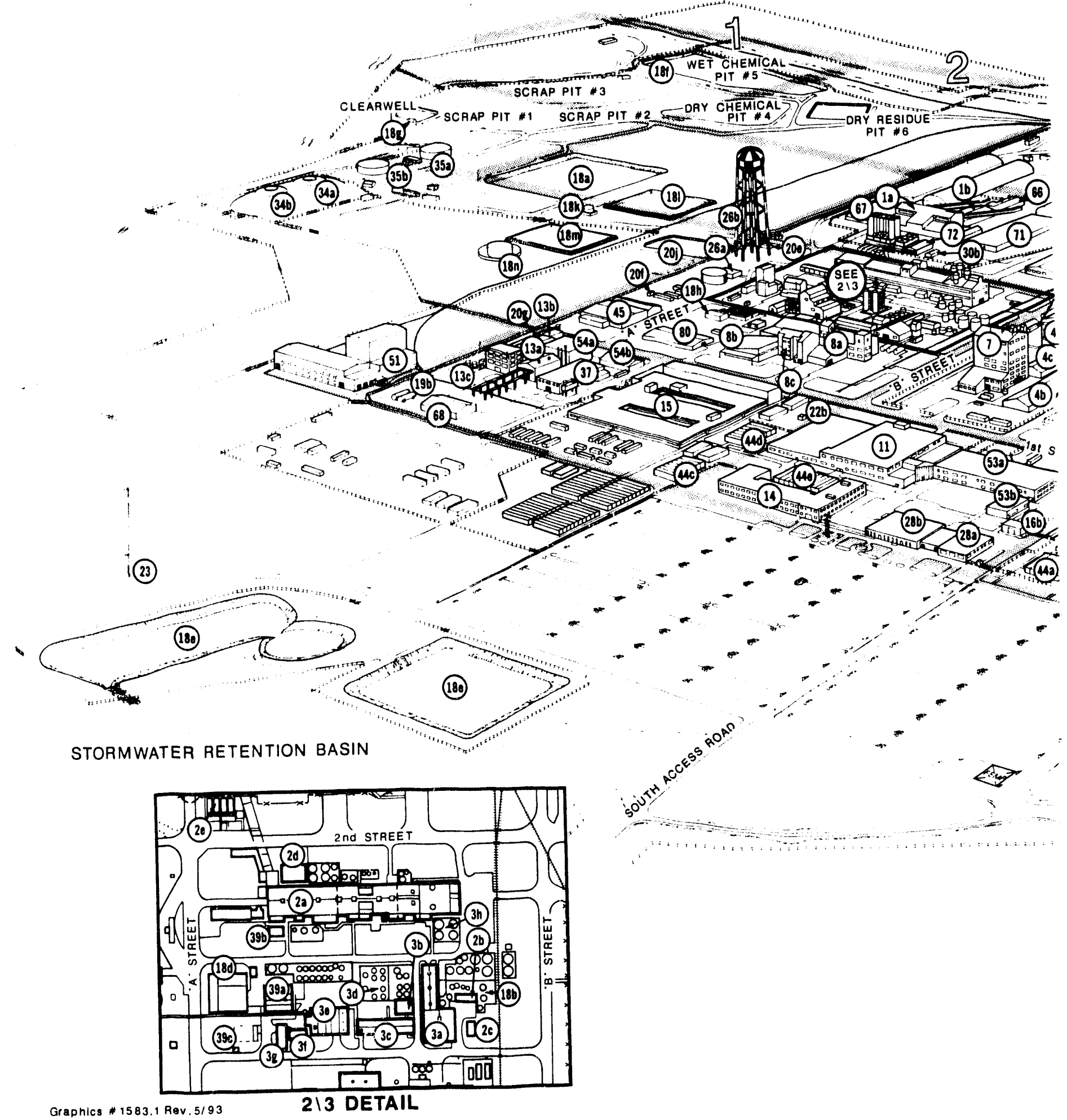




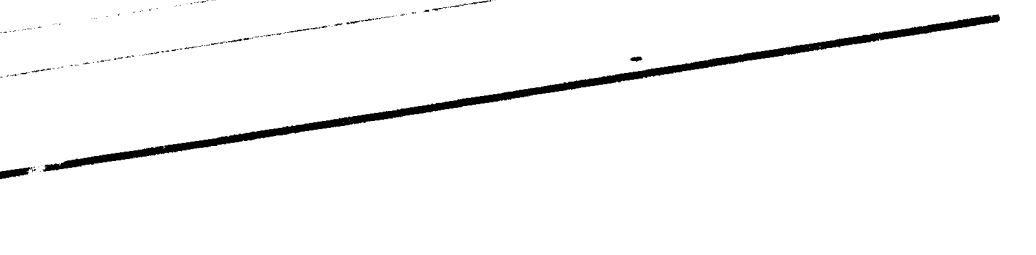

(1D)

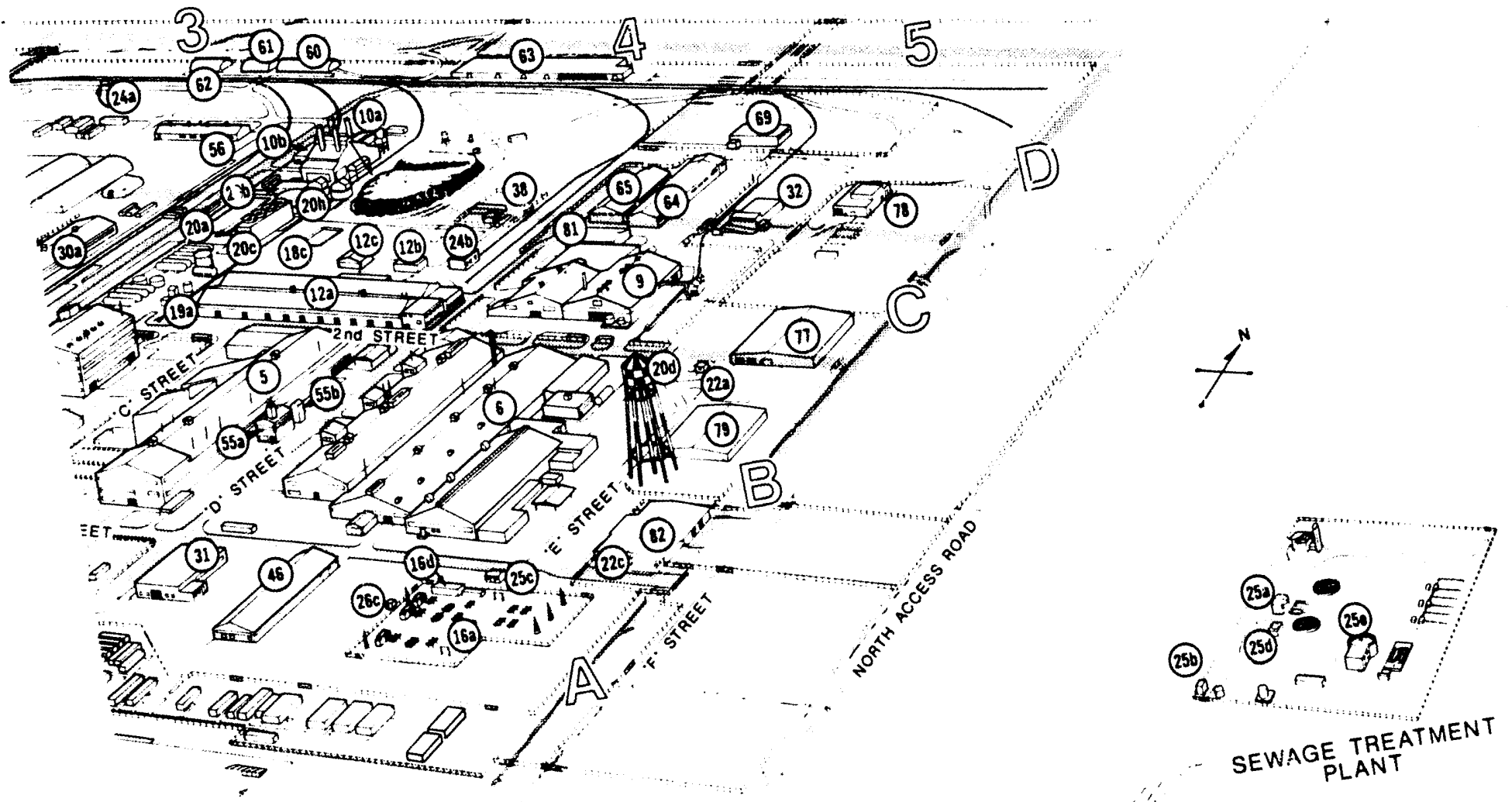

993 Fernald Site Environmental Report

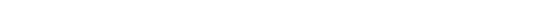




\begin{tabular}{|c|c|c|c|c|c|}
\hline $\begin{array}{l}\text { Building } \\
\text { ID No. }\end{array}$ & $\begin{array}{l}\text { Grid } \\
\text { Coordinates }\end{array}$ & Title & $\begin{array}{l}\text { Building } \\
\text { ID No. }\end{array}$ & $\begin{array}{l}\text { Grid } \\
\text { Coordinates }\end{array}$ & Title \\
\hline 00 & $\star \star$ & General & $22 c$ & A-5 & Truck Scale \\
\hline la & $C \cdot 3$ & Preparation Plant & 23 & * & Meteorological Tower \\
\hline ib & $C-3$ & Plant I Storage Building & $24 a$ & $D-3$ & Railroad Scale House \\
\hline $2 a$ & B-3 & Ore Refinery Plant & $24 b$ & $C-4$ & Railroad Engine Building \\
\hline $2 b$ & B-3 & Lime Handling Building & $25 a$ & * & Chlorination Building \\
\hline $2 c$ & B-3 & Bulk Lime Handling Building & $25 b$ & * & Manhole-175 \\
\hline $2 d$ & B-3 & Metal Dissolver Building & $25 c$ & $A-5$ & Sewage Lift Station Building \\
\hline $2 €$ & $C-3$ & NFS Storage and Pump House & $25 d$ & $*$ & U.V. Disinfection Building \\
\hline $3 a$ & B-3 & Maintenance Bulding & $25 e$ & $\star$ & Digester Control Building \\
\hline $3 b$ & $B-3$ & Ozone Building & $26 \pi$ & B-3 & Pump House - H.P. Fire Protection \\
\hline $3 c$ & B-3 & Control House & $26 b$ & $B-3$ & Elevated Water Storage Tank \\
\hline $3 d$ & $B-3$ & NAR Towers & $28 \pi$ & A-4 & Security Building \\
\hline $3 e$ & B-3 & Hot Raffinate Building & $28 \mathrm{~b}$ & A-4 & Human Resources Building \\
\hline $3 f$ & B-3 & Digestion Fume Recovery & 30a & $C-3$ & Chemical Warehouse \\
\hline $3 g$ & $B-3$ & Refrigeration Bullding & $30 b$ & $C-3$ & Drum Storage Warehouse \\
\hline $3 h$ & B-3 & Refinery Sump & 31 & A. 5 & Engine House - Garage \\
\hline $4 \pi$ & B- 4 & Green Salt Plant & 32 & D.5 & Magnesium Storage \\
\hline $4 b$ & B-4 & Plant 4 Warehouse & $34 \pi$ & B-1 & K-65 Storage Tank - North \\
\hline $4 c$ & $B-4$ & Plant 4 Maintenance Building & $34 b$ & $B-1$ & K-65 Storage Tank - South \\
\hline 5 & B-4 & Metals Production Plant & $35 \pi$ & $C-1$ & Metal Oxide Storage Tank - North \\
\hline 6 & $B-5$ & Mctals Fabrication Plant & $35 b$ & B-1 & Metal Oxide Storage Tank - South \\
\hline 7 & B. 4 & Plant 7 & 37 & A. 3 & Pilot Plant Annex \\
\hline $8 \pi$ & B-3 & Recovery Plant & 38 & 0.4 & Prodane Storage \\
\hline $8 \mathrm{~b}$ & B-3 & Maintenance Building & 39 & $B-3$ & Incinerator Building \\
\hline $8 c$ & B.3 & Rotary Kiln/Drum Reconditioning & 390 & B. 3 & Shelter Storige Building \\
\hline 9 & $(-5$ & Special Products Plant & $39 c$ & $B-3$ & Incinerator Building Sprinkler \\
\hline $10 \mathrm{ct}$ & D. 4 & Boiler Plant & & & Riser House \\
\hline $10 \mathrm{~b}$ & D.4 & Boller Plant Mantenance Buildıng & $44 a$ & A. 5 & Tratler Complex - - -Plex $(E$ ast $\rangle$ \\
\hline 11 & A. 4 & Service Building & $44 c$ & A. 3 & Traller Complex - 7 Plex (South) \\
\hline $12 \pi$ & C. 4 & Maintenance Bulding (Main) & $44 d$ & A. 3 & Trailer Complex - 7-Plex (North) \\
\hline $12 \mathrm{~b}$ & C. 4 & Cylinder Storage Building & $44 e$ & A. 4 & Trailer Complex - - 10-Plex \\
\hline $12 c$ & C. 4 & Lumber Storage Building & 45 & $B-3$ & Rust Engineering Building \\
\hline $13 \mathrm{c}$ & A. 3 & Pilot Plant We Side & 46 & A. 5 & Heatly Equipment Garage \\
\hline $13 t$ & A.3 & Pilot Plant Mantenarice Building & 51 & A.2 & UF, to UF Redurtion Facdity 11 \\
\hline $13 c$ & A.3 & Sump Pump House & $53 \pi$ & A.4 & Occupational Safety \&x Health \\
\hline 14 & A. 4 & Administration Building & 5.30 & A. 4 & In-Vivo Building \\
\hline 15 & A-3 & Laboratories & 5401 & $A-3$ & UF to UF Reduction Facility I \\
\hline $16 \mathrm{a}$ & $A-5$ & Main Electricat Stationi & $54 b$ & A.3 & Pilot Plant Warehousc: \\
\hline $16 b$ & A. 4 & Electrical Substition & $55 a$ & B-4 & Slag Recycling Plant \\
\hline $18 \pi$ & $C-2$ & Biodentrification Surge Lagoon & 556 & B. 4 & Slag Recycling Pitelevator \\
\hline 181 & B. 3 & Generai Sump & 56 & D-3 & CP Storage Watehouse: \\
\hline $18 \mathrm{c}$ & $C .4$ & Codl Pilc Runoff Basin & 60 & D-3 & Quonset tur \#1 \\
\hline $18 d$ & B. 3 & Biodentrification Towers & 61 & $D-3$ & Ouonset Hut \#2 \\
\hline 180 & & Stormwater Retention Basin & 62 & D. 3 & Ouonset Hut \#3 \\
\hline 181 & D. 1 & Pit 5 sluice Gate & 63 & D. 4 & KC -2 Warehouse \\
\hline 189 & $c-1$ & Clearwell Pump House: & 64 & 0.5 & Thorum Warehouse \\
\hline $18 \mathrm{~h}$ & B3 3 & BDN Effluent Treatment Fetillty & 65 & 0.5 & (Old) Plant 5 Warthouse \\
\hline $18 \mathrm{k}$ & B. 2 & Methanol Tank & 60 & C. 3 & Drum Reconditioning Building \\
\hline 181 & $C \cdot 2$ & Low Nitrate' Tetnk. & 67 & $C-3$ & Plant 1 Thornum Warchouse \\
\hline $18 \mathrm{~m}$ & $8 \cdot 2$ & High Nitratc Tank & 68 & A. 3 & Pliot Plant Warchouse \\
\hline $18 n$ & $B 2$ & High Nitrate Storage Tank: & 69 & 0.5 & Decontamination Bulding \\
\hline $1 \% \mathrm{~d}$ & $C .4$ & Mann Motal Tank Farm & 71 & C 3 & General InProcess \\
\hline 190 & A. 3 & Pilot Plant Ammonia Tank Farm & & & Storage Wratehouse \\
\hline $20 \mathrm{~A}$ & C. 4 & Pump Statton and Power Centes & 72 & $C \cdot 3$ & Drum Siorage Building \\
\hline 200 & D. 4 & Water Plant & 73 & & Fire Brigade Training \\
\hline $20 \mathrm{c}$ & $C .4$ & Cooling Towers & & & Conter Building \\
\hline $20 \mathrm{~d}$ & B.5 & $\begin{array}{l}\text { Elevated Storage lank } \\
\text { (Potable } \mathrm{H} \text { O) }\end{array}$ & $\begin{array}{l}77 \\
78\end{array}$ & cis & $\begin{array}{l}\text { Finshed Produres Wareheouse } \\
\text { New DEx Fetellity }\end{array}$ \\
\hline 200 & B.3 & Well House \#1 & 79 & B.5 & Plant 6 Warrenouse \\
\hline $20 f$ & B. 3 & Well House \#2 & 80 & B-3 & Pant 8 Warchouse: \\
\hline $20 \mathrm{~g}$ & A.3 & Well House \#3 & 81 & $c 5$ & Pant 9 Waretiouse: \\
\hline $20 \mathrm{n}$ & D. 4 & Process Water Skentge Tank & 82 & $B 5$ & Receiving \& Incoming \\
\hline $20 j$ & B? & Lime Slurry Pis & & & Mrteristls Inepertion Ared \\
\hline $22+$ & B.5 & Gits Meter Building & Cunder & Penmeter & anterterese \\
\hline 220 & A. 3 & Stom Sewer Lift Station & NOHE & try undentit & 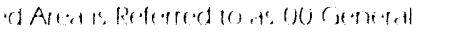 \\
\hline
\end{tabular}




\section{Hazardous}

- Heavy metals,

- Hydrochloric acid.

- Laboratory chemicals,

- Methanol,

- Nitric acid.

- Process waste.

- Sodium hydroxide. and

- Sulfuric acid.

The site has repackaged some materials into new drums and removed materials no longer needed since production ended. For example, thorium previously stored in a deteriorating above-ground silo, in bins, and in drums on an outdoor pad has been repackaged in new drums and stored in a warehouse. The Fernald site has significantly reduced its inventory of chemicals once used for production by disposing of them at designated waste disposal facilities.

\section{Environmental Program Information}

As a result of the continued onsite storage of radioactive and hazardous waste, the Fernald site conducts environmental program activities to monitor and maintain environmental quality in the area surrounding the site. Some of these activities include the Environmental Monitoring Program, the Meteorology Program. Natural Resource Management, and the Waste Minimization Program which are described below.

\section{Environmental Monitoring Program}

Federal and state waste management requirements that were applied during the site operation period are still in effect because of the onsite waste storage. Earlier regulations were often less stringent, and the effects of past operations are still evident. Today, Fernald site personnel continue to investigate these effects on the environment. The Environmental Monitoring Program plays a key role in this effort. Like any complex program or investigation, the Environmental Monitoring Program was developed after careful consideration of many comporicntc. For example, former site production processes, which involved both radioactive and nonradioactive materials, resulted in air and liquid releases to the environment. The monitoring program is largely based upon the flow of these materials through the air and liquid pathways. Additional program components address contamination risks associated with cleanup procedures. 
Environmental monitoring activities seek to determine the amount of radioactive and nonradioactive materials that leave the site and enter the surrounding environment. In short, this year-round Environmental Monitoring Program has several responsibilities:

- Ensure that the site has procedures in place to detect any release of materials so that corrective actions can be taken as quickly as possible,

- Closely monitor releases to ensure that air emission and liquid effluent standards and guidelines are not exceeded,

- Evaluate the impact of site activities (past and present) on the environment,

- Estimate the radiation dose that area residents may be exposed to as a result of former production operations and current cleanup activities at the site, and

- Measure progress in correcting problems from past operations and in implementing improved environmental management practices.

\section{Meteorology Program}

The Fernald site's meteorological monitoring system was installed in August 1986. The meteorological tower is 60 meters (200 feet) tall, with monitoring equipment at both the 10-meter (33-foot) and 60-meter (200-foot) heights. The tower instruments measure wind speed and direction, ambient air temperature, relative humidity, barometric pressure, and precipitation (see Table I on page A-2).

The meteorological instruments are inspected and re-calibrated regularly to ensure that they are functioning properly. The system is down during these routine maintenance periods but not for a length of time that significantly affects the database. While the system is down, it is possible to obtain meteorological data from the Greater Cincinnati - Northern Kentucky International Airport, located about 27 km (17 miles) south of the site.

The meteorological data gathered at the site are primarily used to evaluate climatic conditions at the site. The Environmental Monitoring Program uses atmospheric models to determine how airborne effluents are mixed and dispersed. These models are then used to assess the impact of operations on the surrounding environment, in accordance with DOE requirements.

Airborne pollutants are subject to whatever weather conditions exist. Wind speed and direction, rainfall, and atmospheric stability play a role in predicting how pollutants are distributed in the environment. Weather data, particularly wind speed and direction, provide guidance in collecting environmental samples and locating monitoring stations.

Figures 4 and 5 are annual wind roses, which illustrate the average wind speed and general direction measured at the 1()-meter (3.3-foot) and 6()-meter (20)-foot) levels in 1993. The wind direction was predominantly toward the northeast. blowing from the southwest sector approximately $11 \%$ of the time at the 10 -meter $(33-$ foot) level 


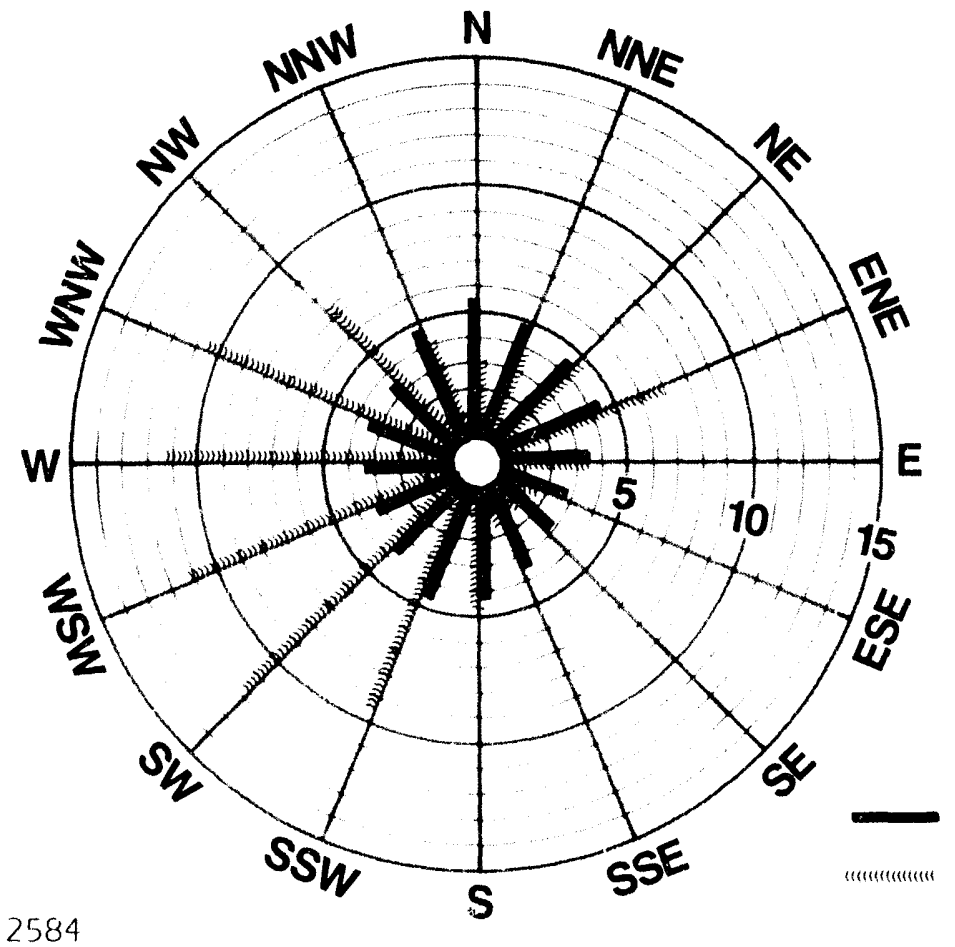

Average wind speed from this direction. Percentage of time that the wind blew from this direction.

Figure 5: 1993 Wind Rose Data, 60-Meter Height

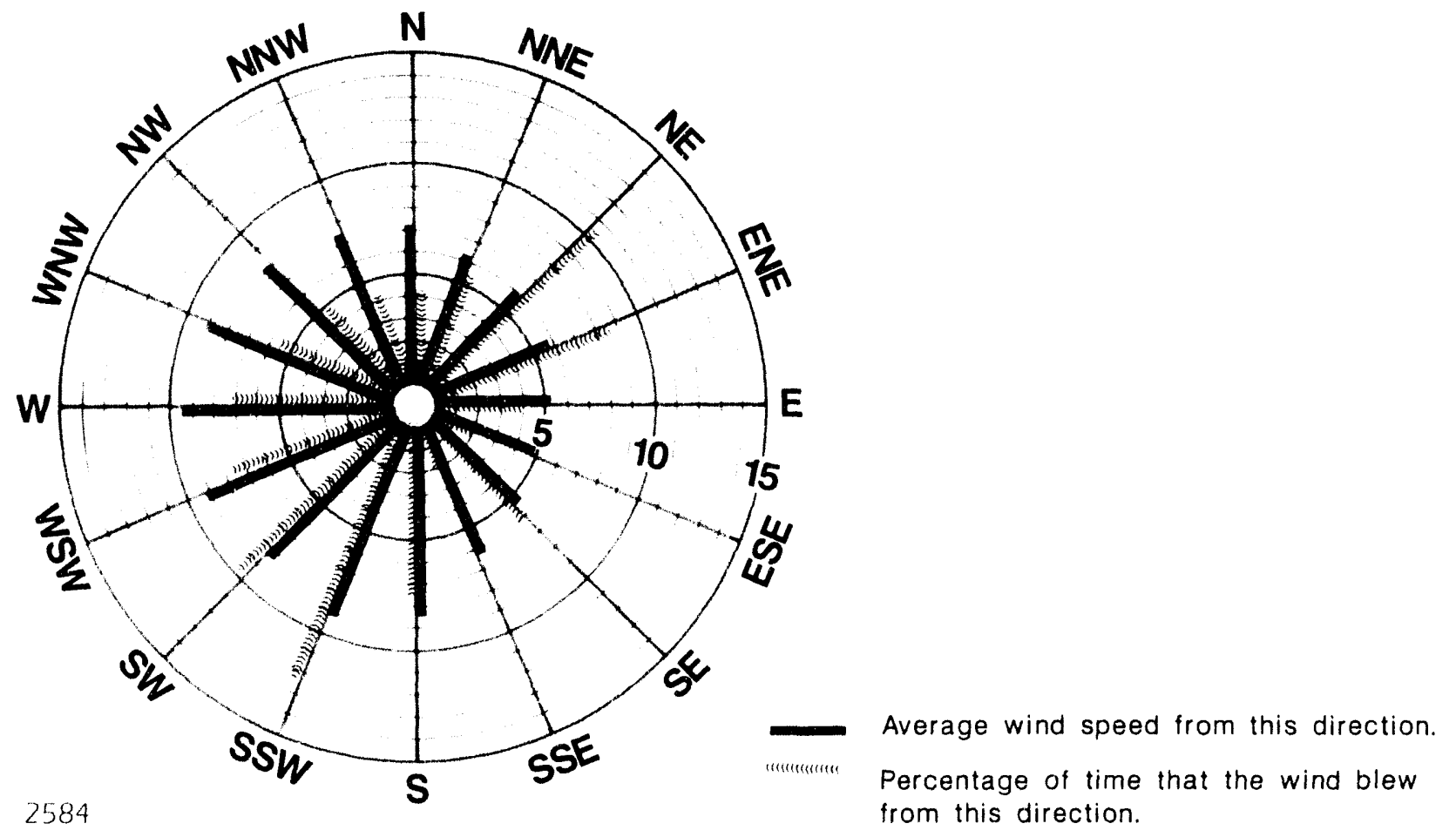


and from the south-southwest sector approximately $12 \%$ of the time at the 6() -meter (20)-foot) level. Winds were calm $13.4 \%$ of the time from the 1() -meter (33-foot) level and $2.6 \%$ of the time from the 6() -meter (2())-foot) level.

Trees growing near the meteorological tower have had an effect on the measured wind speeds at the 10-meter (33-foot) level because they acted as a wind barrier. After considering the options, the site decided that the most effective and economical solution was tree removal. In November 1993, in coordination with National Environmental Policy Act (NEPA) requirements and after determining there would be no radiological impact, trees within a 107 -meter (350-foot) radius were cut down. These trees were placed in several brush piles in the vicinity of the meteorology tower to enhance existing wildlife habitat. The meteorological tower instruments and computer system are being upgraded as well. These changes should more accurately reflect actual meteorological conditions at the Fernald site and will be detailed in the 1994 Site Environmental Report.

In 1993. the precipitation measured at the Fernald site was $98 \mathrm{~cm}$ ( 39 inches), which is slightly less than the average annual precipitation of $1(14 \mathrm{~cm}$ (41 inches) for 1963 through 1992. Figure 6 shows 1993 total precipitation for the area in relation to the annual precipitation amounts recorded since 1983. (Precipitation totals for 1983 through 1992 were taken from the measurements made at the Greater Cincinnati Northern Kentucky International Airport hecause of a computer software problem at the site meteorological tower. This problem was corrected, and the 1993 total wats taken from measurements made at the Fernald site.)

Figure 6: Annual Precipitation Data, 1983 - 1993*

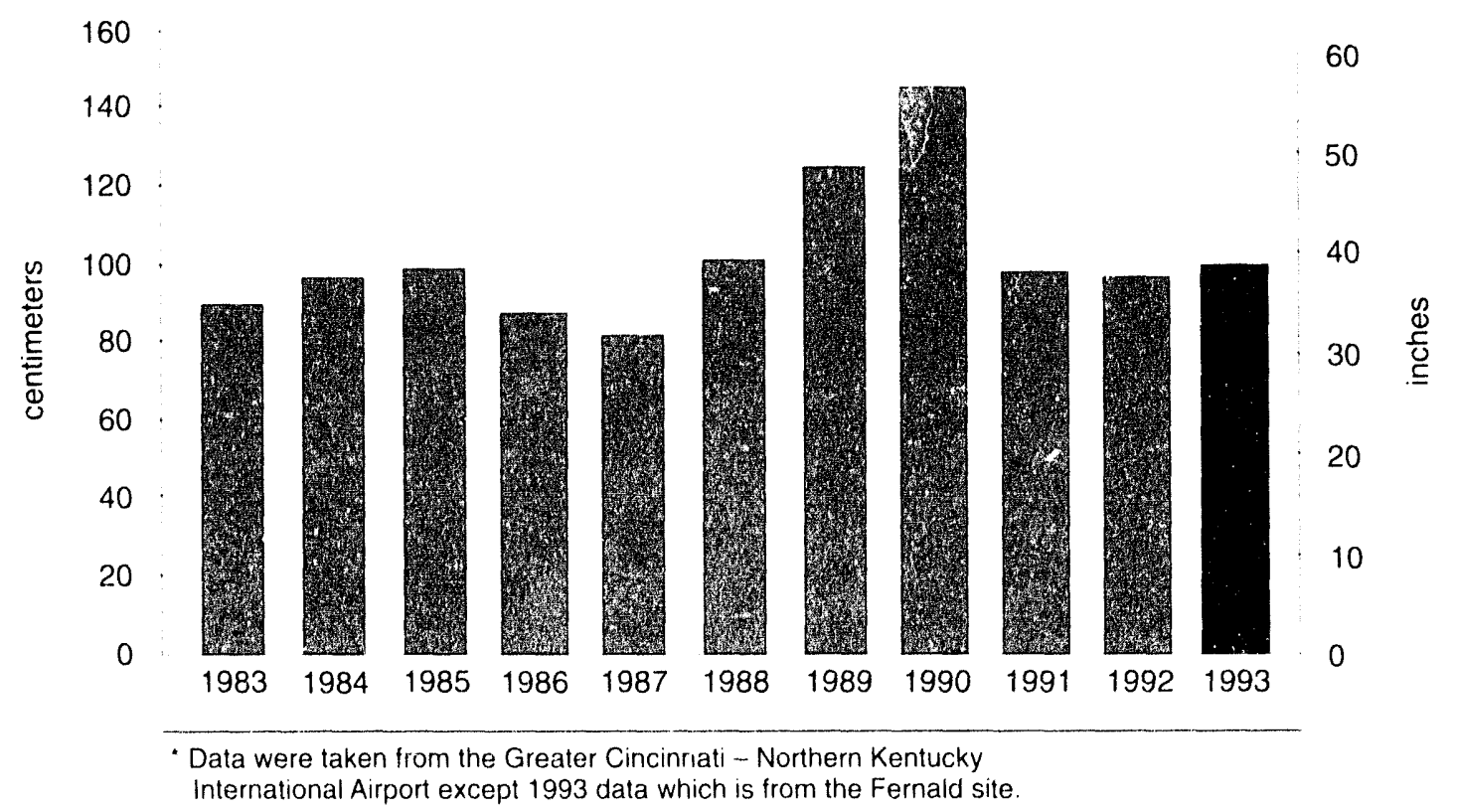




\section{Waste Minimization Program}

A challenge at the Fernald site, whose mission is environmental remediation, is to include waste minimization planning and concepts in all activities and minimize any secondary wastes resulting from the remediation activities. The Waste Minimization Program at Fernald matured in 1993. Programs that were initiated in 1992 began to show cost savings, cost avoidances, and a reduction in disposal volumes. It also became apparent in 1993 that there is a greater potential for minimizing wastes during remediation with new technologies and updated policies and procedures.

Large-scale recycling and reuse activities were initiated with a total of $6,335 \mathrm{~m}^{3}$ $\left(223,700 \mathrm{ft}^{3}\right)$ of scrap metal either recycled or beneficially reused within the DOE complex. The successful implementation of this activity focused attention on the feasibility of recycling. A new Recycling Department was formed with the function of establishing mechanisms for the recycling and reuse of waste and scrap material from decontamination, decommissioning, and dismantling operations.

The Fernald site Waste Minimization and Pollution Prevention (WM/PP) Policy became effective in October 1993 and set forth a commitment to protect the environment through WM/PP efforts including source reduction, recycle/reuse, segregation. and good operating practices.

In an effort to integrate WM/PP practices into each site activity, an educational program was developed for all project and design engineers. The program's objective is to assist engineers in applying a life-cycle cost analysis of waste to determine the most environmentally sound and cost-effective project alternative using WM/PP practices.

Additional waste minimization accomplishments in 1993 include the following:

- Recycled $36,320 \mathrm{~kg}$ (80,000 pounds) of lead-acid batteries instead of disposing them as hazardous waste;

- Recovered and reused $29 \mathrm{~kg}$ ( 63 pounds) of freon from drinking fountains and air conditioning units:

- Recycled 1,453 kg (3,200 pounds) of metal from PCB- containing light ballasts;

- Segregated $5,429 \mathrm{~m}^{3}\left(191,700 \mathrm{ft}^{3}\right)$ of flyash and $130 \mathrm{~m}^{3}\left(6,480 \mathrm{ft}^{3}\right)$ of asbestos containing materials for disposal as sanitary waste instead of managing as low-level waste;

- Recycled 7,264 $\left.\mathrm{m}^{3}(256,500) \mathrm{ft}^{3}\right)$ of office paper, cardboard, glass, and polystyrene:

- Recycled $2,588 \mathrm{~kg}(5,750$ pounds) of aluminum cans and, as a result, donated $\$ 1,400$ to a local elementary school for an ecology program;

- Segregated controlled-area office trash and established administrative controls in order to divert the trash from disposal as low-level waste, with a cost-savings of more than $\$ 62,(0)()$; 
- Purchased laboratory chemicals as needed instead of in bulk;

- Revised the specifications for the purchase of paper products to require that the paper contains a recycled fiber content of $50 \%$ waste paper and $10 \%$ post consumer;

- Washed and reused cloth anti-contamination clothing instead of generating paper anti-contamination clothing, reducing the generation of approximately $1.1 \mathrm{~m}^{3}\left(40 \mathrm{ft}^{3}\right)$ of waste per day;

- Sponsored three "Reuse Days" in which unused, old, or extra office supplies were displayed for reuse instead of ordering new supplies; and

- Included waste minimization awareness in employee training courses.

\section{Natural Resource Management}

The management of natural resources will be an ongoing process as long as DOE retains ownership of the site. Natural resources have aesthetic, ecological, educational, historical, recreational, and scientific value to the United States. The following discussions provide information on the natural resources found on Fernald site property.

\section{Ecology}

Representative of the regional ecology, the area's natural vegetation is comprised of a broad-leafed deciduous forest, dominated by beech and maple hardwoods. Some of these naturally wooded areas still exist north of the site and in the Paddys Run watershed to the west. Sixty-two acres immediately north of the production area were planted with white and Austrian pines as part of a 1973 environmental improvement project. Non-native grasslands cover most of the remainder of the site, and local dairy farmers lease Fernald site pastures for their herds to graze, consistent with the property's former agricultural uses. The plant diversity provides abundant cover for deer, eastern cottontails, woodchucks, and bobwhite quail; predatory birds, such as red-tailed hawks, have also been observed on Fernald site property. Song sparrows, blue jays, cardinals, and robins nest in the pine plantations, while Paddys Run is home to numerous species of small fish, including minnows, darters, and shiners.

In 1986, biologists from Miami University in Oxford, Ohio, began a comprehensive ecological study of the site. In addition to collecting extensive ecological baseline data, they also studied plants and animals to determine if any species were being stressed by former site operations. Based on statistical analyses, the study concluded that the site's impact on the natural habitat did not appear to be different from the ecological impact of any other local industrial site. Their report, published in 1990, also concluded that no plants or animals found onsite at that time were on the federal endangered species list. ${ }^{2}$ 


\section{Threatened and Endangered Species}

The Endangered Species Act states that all federal agencies must seek to conserve federal-listed threatened and endangered species. The site has conducted surveys since the Maami University study to gather updated information on any threatened or endangered species that may be found onsite. The Indiana bat (Myotis sodelis) and the running buffalo clover (Trifolium stolonifertum), which are both on the federal list, may occur at the site, and suitable habitat has been identified on Fernald site property. Both of these species are found to occur in the surrounding areas. Several state-listed threatened and endangered species have been seen on or near the Fernald site property, including the cave salamander (Eurycea lucifinga), Sloan's crayfish (Orconectes sloanii), slender lingergrass (Digitaria filiformis), mountain bindweed (Polygonum cilinode), and spring coralroot (Corallorhiza wisteriana). There are several species of threatened and endangered migratory birds that pass through the site. Some of the birds that have actually been spotted onsite include the northern harrier (Circus cyaneus), northern waterthrush (Seiurus noveboracensis), and darkeyed junco (Junco hyemalis).

\section{Wetlands}

Wetlands are defined as areas covered or salurated with water for enough time to support water-loving vegetation. A wetland delineation was conducted on the site in December 1992 and January 1993. A total of 15 hectares ( 36 acres) of freshwater wetlands were delineated on the Fernald site. Delineated wetlands included 11 hectares (27 acres) of palustrine forested wetlands, 3 hectares ( 7 acres) of drainage ditches/swales, and I hectare ( 2 acres) of isolated persistent emergent and scrub/ shrub wetlands. A wetland delineation is scheduled to be conducted every three years in order to provide current information.

\section{Floodplains}

Floodplains within the site property are confined to the north-south corridor that contains Paddys Run. Outside of the site boundaries, the 10()- and 5())-year floodplains of the Great Miami River extend west of the "Big Bend" region, which is east of the Fernald site. It also extends northward along Paddys Run from the confluence of the two waterways past the southern boundary of the site. This area overlaps a body of uranium-contaminated groundwater called the South Plume.

\section{Cultural Resources}

The population and cultural growth of an area are determined by factors such as geologic setting, surface waters, soils, vegetation, and climate. The Fernald site and surrounding area are located in a region of rich soil and many sources of water, such as the Great Miami River. As a result, the area has a rich cultural resource diversity. This diversity is evident by the number of historical periods represented in the area's history. These periods include the following:

- Paleo-Indian Occupation (120)(0) BC-8000) BC),

- Archaic Oecupation (80)() BC-10()() BC), 
- Woodland Tradition (IO)(O) BC - I(X) AD),

- Mississippian Tradition ( $(0(0)$ AD - 1660) AD), and

- Historic Times (1660) AD - Present).

\section{Local Geography}

A variety of regional physical, ecological, and human characteristics form the context in which environmental monitoring results must be analyzed. By studying various elements of the local geography, scientists and engineers are better able to identify the impact of former production activities. Remedial techniques are then designed to restore the physical environment to its original state or to an established cleanup standard. The following sections describe several of these characteristics. beginning with the geologic origins of the area.

\section{Geologic History}

About 450) million years ago, in the Late Ordovician period, sediments were deposited in a shallow sea. These sediments solidified over time to become predominantly shale with alternating thin layers of limestone. This strata is known universally ats the Cincinnatian Series. The shale is the relatively impermeable bedrock underlying the site.

An ancient river cut into the shale bedrock to about 60) meters (2( $(0)$ feet) below the present-day Great Maami River, forming a channel named the New Haven Trough. Later, the Illinoisan and Wisconsin glaciers (about 40,(0)( years ago and 10,(0)() years ago, respectively) advanced into the area during the Pleistocene epoch. These glaciers crushed rocks as the ice moved southward from the arctic region. As the glaciers receded, they filled the trough with sand and gravel sediments.'

The last of the glaciers in the Fernald area deposited a relatively impermeable glacial till over the sands and gravel. A mix of clay, silt, sand, gravel, and cobbles. this glacial till is unevenly deposited throughout the area and makes up the local orerburden.

The Great Miami River and its tributaries have eroded significant portions of the overburden and left terrace remnants which stand higher than surrounding bottom lands of the river valley. The Fernald site lies on top of one of these terrace remnants, about 177 meters ( 580 feet) above sea level. The property rises to 21.3 meters (7)(K) feet) at the northern boundary of the site and slopes downward to 168 meters (550 feet) at Paddys Run. North and south-southwest of the site, the hills peak at about 260 meters (850 feet) and 235 meters (770) feet), respectively. The elevation of the Great Miami River, east of the site, is about 165 meters (540 feet), while the land rises gently 10 about 18.3 meters (6)( ) feet) west of the site. Figure 7 presents a crosssection of the area. 


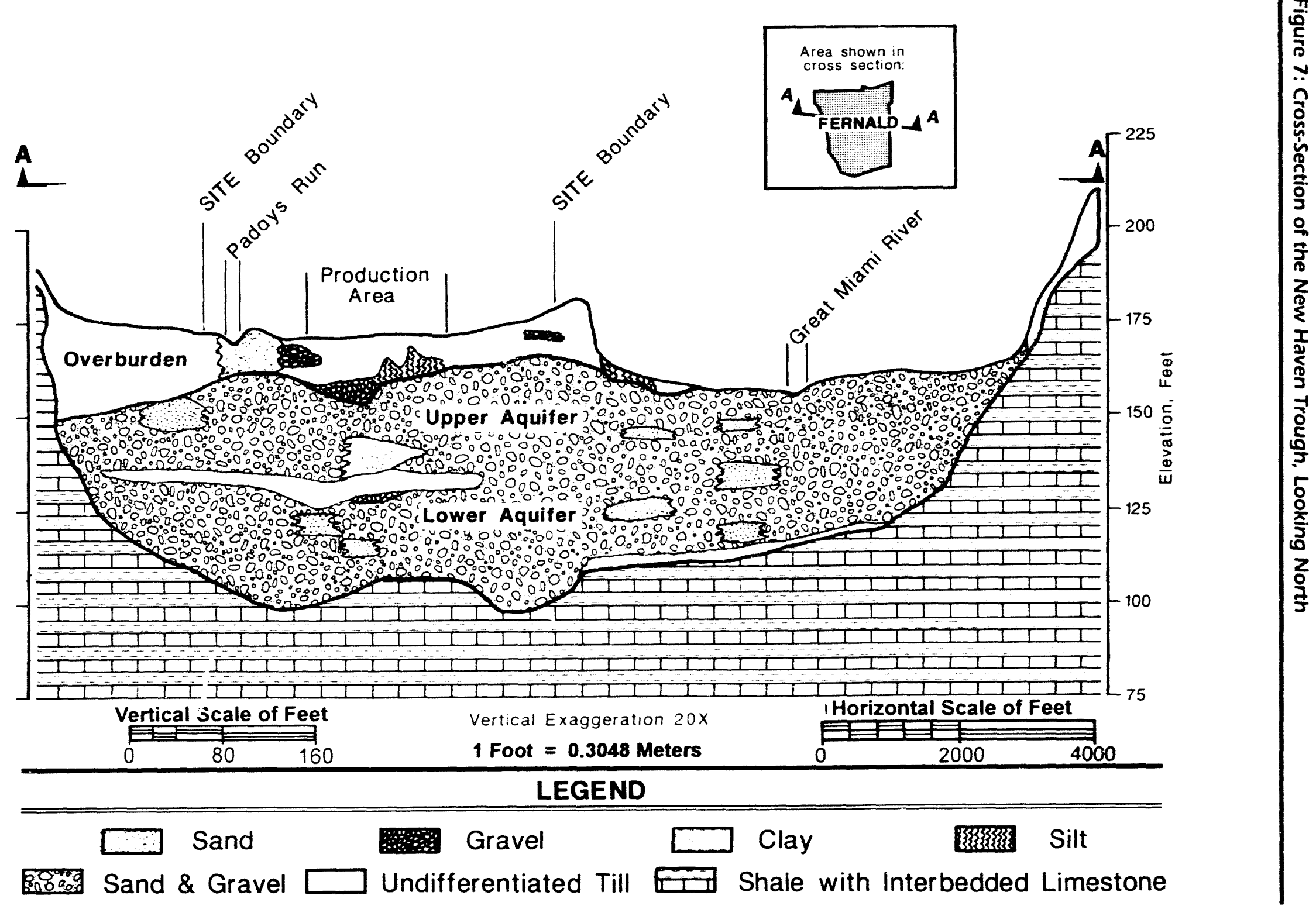




\section{Lithology}

Lithology is the study, classification, and mapping of rocks and rock formations. This science is vital in determining the location. flow, and direction of groundwater. The shale underlying the site forms the floor and valley walls of the New Haven Trough and is generally between 18 and 60 meters $(60)$ and 200 feet) below the ground surface. The elevation of the bedrock surface varies from $1(0)$ meters (330) feet) above sea level south of the production area to 122 meters $\left(4(0)\right.$ feet) just north of the site. ${ }^{4}$

Sand and gravel filling the New Haven Trough are up to 60) meters (20) feet) thick. This relatively porous material makes up the Great Miami Aquifer. About 30 to 38 meters ( 100 to 125 feet) below the surface of the Fernald site, the sand and gravel is divided by a greenish-black silty clay layer, about 3 to 6 meters (I) to 20 feet) thick. ${ }^{4.5}$ Data collected as part of the ongoing Remedial Investigation and Feasibility Study (RI/FS) suggest that the clay layer extends from west of Paddys Run to the center of the production area and is present beneath the waste pit area. The clay layer does not extend east or south of the production area.

A silty clay glacial till overlies the sand and gravel aquifer. This dense overburden, ranging in thickness between 6 and 15 meters (20) and 50) feet), varies in composition both vertically and horizontally. The elevation of the base of the overburden is 165 meters (540 feet) above sea level. ${ }^{4,56}$ The silty clay overburden continues north and east of the site, where it rests upon the shale bedrock. However, in the lower reaches of Paddys Run and the outfall ditch, the clay has eroded, exposing the underlying sand and gravel and giving the aquifer direct contact with surface runoff.

\section{Groundwater Hydrology}

Hydrology is the study of the properties, distribution, and circulation of water through the local environment. Surfice hydrology, discussed in the next section, is the study of drainage systems like rivers, streams, and rainwater runoff. Groundwater hydrology, discussed here, focuses on the movement of water below the earth's surface.

Groundwater beneath the site exists in the glacial overburden as perched water in a sand and gravel aquifer and, to a much lesser extent, in the underlying bedrock. Perched water occurs when water sinking through the earth from the surface is trapped above very dense clay. Some of this perched water may slowly seep through the clay, but most remains trapped. At the Fernald site, perched water is generally found between 0.3 and 3 meters $(1$ 10 10 feet) below the surface. Perched water in the glacial overburden occurs sporadically and is not a sufficient source of drinking water. In the overburden, water does not move as easily as water in the sand and gravel aquifer below since mosi perched water occurs in isolated pockets.? 
Water sinking through the glacial overburden quickly collects in the sand and gravel aquifer, satturating it. Most water is prevented from sinking further by the nearly impermeable rock floor. The top of the aquifer is about 25 meters ( 82 feet) beneath the site, and the aquifer is between 38 and 5.3 meters ( 125 and 175 feet) thick. As shown in Figure 8 . the groundwatcr in the sand and gravel aquifer is moving east under the waste pit and production areas, while on the southern edge of the facility, groundwater moves generally to the south. These groundwater flow data are used to track and forecast the movement of contaminants w'ich may be found in the aquifer.

There may be groundwater even deeper in the slightly permeable rock layers below the sand and gravel aquifer; however, this water is essentially trapped in cracks and fissures and does not contribute any significant amount to the entire flow system.

\section{Surface Hydrology}

The Fernald site is part of the Great Miami River drainage basin, although it is above the floodplain (see Figure 9). Natural drainage from the Fernald site to the Great Miami River is primarily via Paddys Run, a small creek which begins north of the site and flows southward along the western edge of the site. This intermittent stream begins losing flow to the underlying sand and gravel aquifer south of the waste pit area. Finally, about $2.4 \mathrm{~km}$ ( 1.5 miles) south of the site. Paddys Run cmpties into the Great Miami River.

In addition to natural drainage through Paddys Run, site runoff is collected, treated, and discharged to the Great Miami River through an effluent pipeline. The river, about $1 \mathrm{~km}(0.6$ mile) east and south of the Fernald site. runs in a southerly direction and flows into the Ohio River about $39 \mathrm{~km}$ ( 24 miles) downstream of the site. Although lurbulence makes the Great Miami River unsafe for swimming, some people do fish there. The segment of the river between the Fernald site and the Ohio River is not designated as a source of public drinking water.

The average flow rate for the Great Miami River in 199.3 was 1.37 cubic meters per second ( 4.836 cubic feet per second), measured daily about $16 \mathrm{~km}$ (10) river miles) upstream of the eflluent discharge. Flow rate also fluctuates throughout the year. In 1993, the maximum rate was $860 \mathrm{cms}(30,4(0)$ efs $)$ measured in November; the minimum flow was $19 \mathrm{cms}$ ( $679 \mathrm{cfs}$ ) measured in September. ${ }^{8}$

\section{Demography and Land Use}

Scattered residences and several villages, including Fernald, New Baltimore. Ross, New Haven, and Shandon. are located near the site (see Figure 10). Downtown Cincinnati is approximately $27 \mathrm{~km}(17$ miles) southeast of the site, and the cities of Hamilton and Fairfield are 10 to $1.3 \mathrm{~km}$ (6 to 8 miles) to the northeast. There is an estimated population of 14.6()$)$ within $8 \mathrm{~km}(.5$ miles) of the Fernald site, and an estimated $2.7+$ million within $80 \mathrm{~km}(.50$ miles). Table 2 on page A-3 shows an estimate of population distribution in the surrounding areals. 


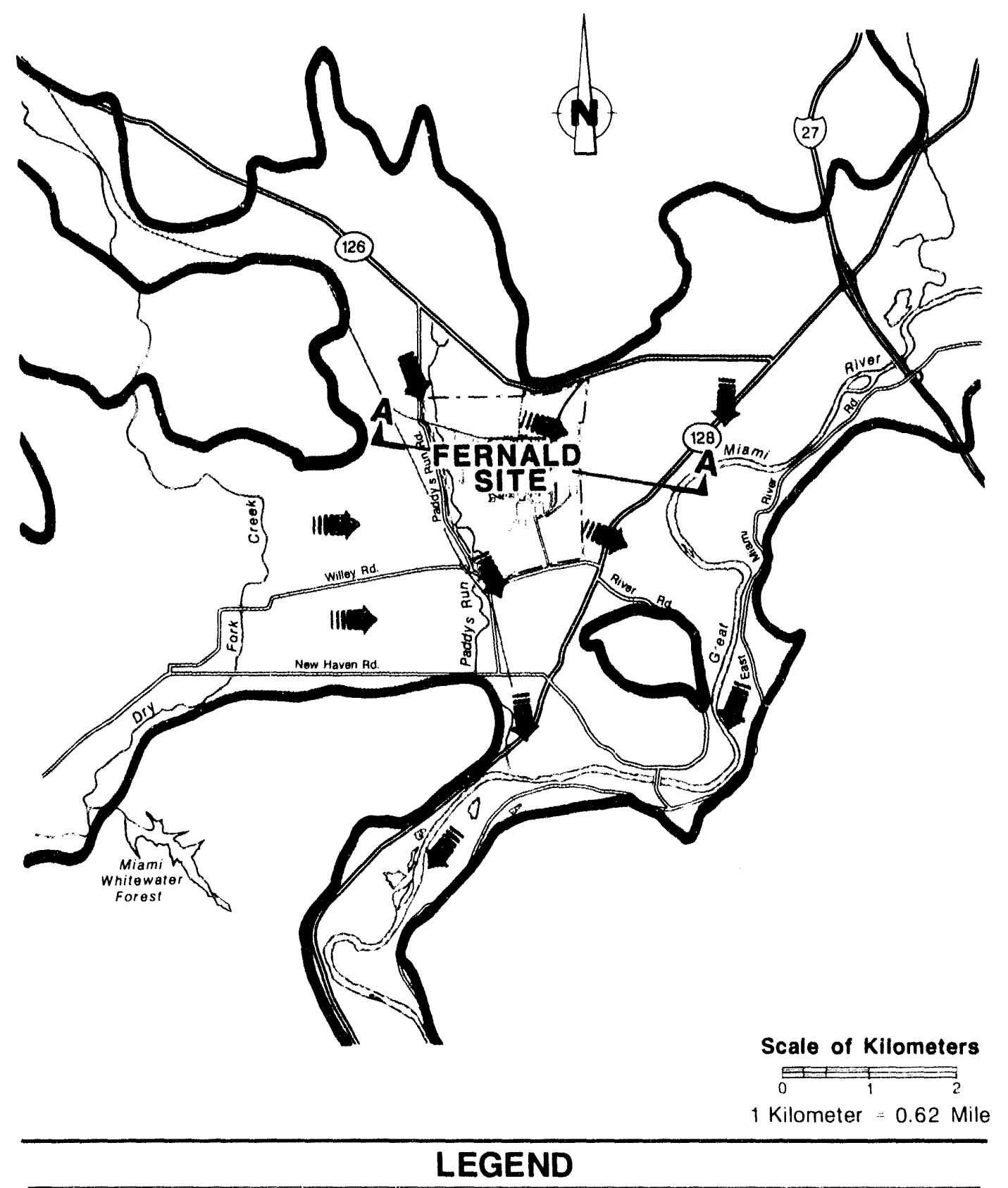

Buried Valley Aquifer
General Direction of
Groundwater Flow $\quad$ A A Location of Cross-Section




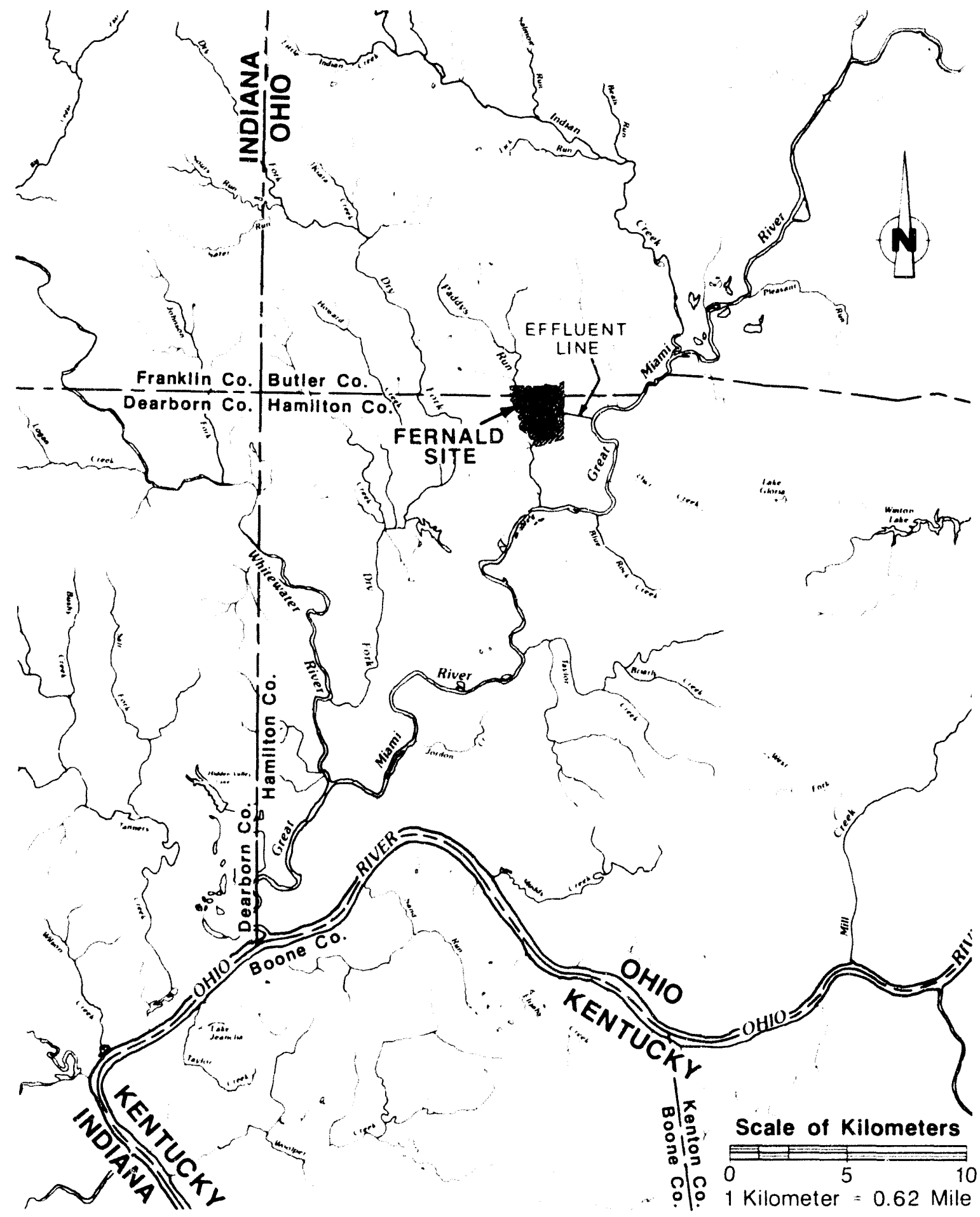




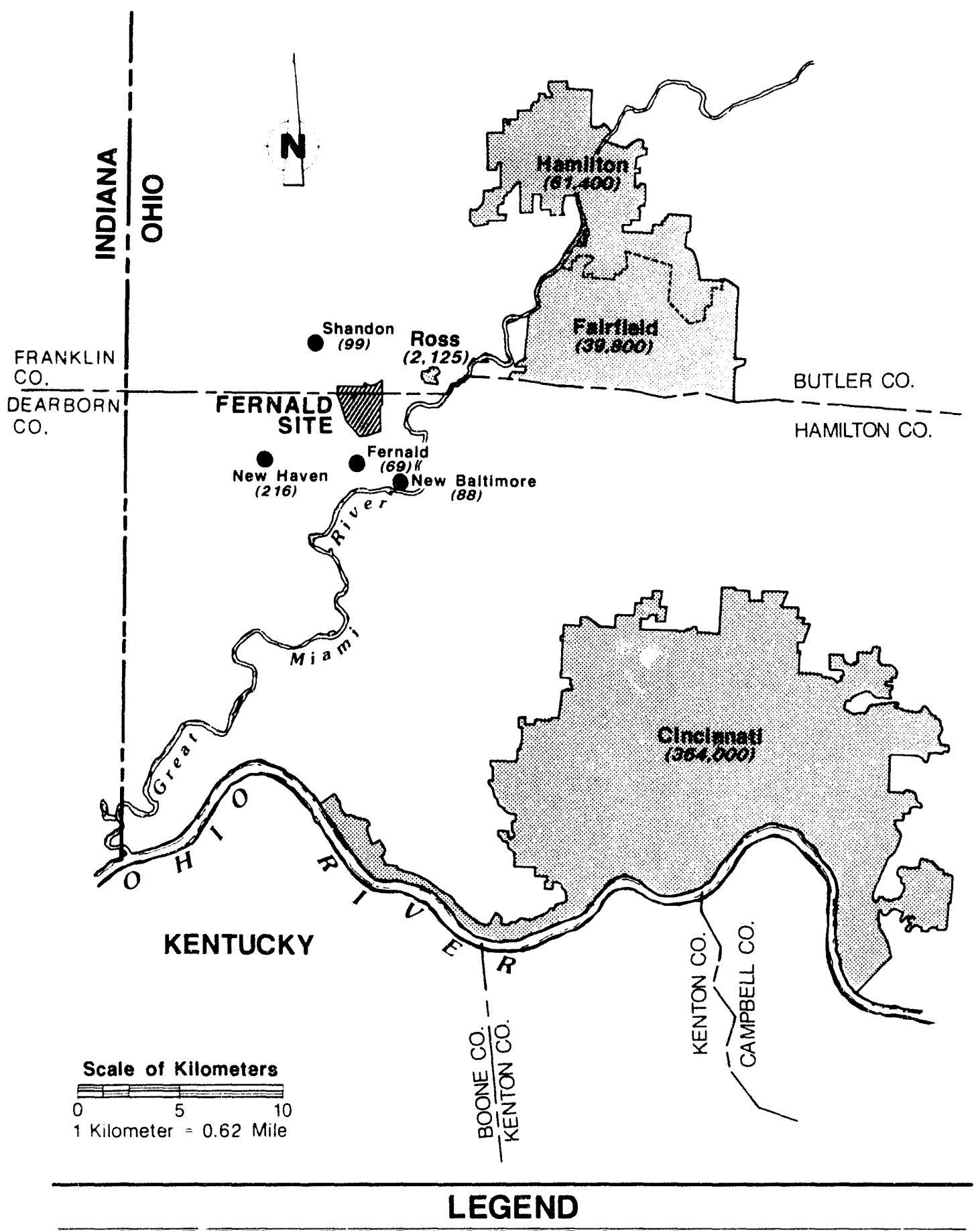

- Population in parenthesis estimated in 1989

Population in parenthesis from 1990 U. S. Census Figures 
The area's major economic activities rely heavily on the physical environment. Farming and raising dairy and beef cattle account for the majority of the land use in the area. Major crops include field corn, sweet corn, soybeans, and winter wheat. Several nearby farms also sell produce locally or in nearby urban markets.

Other important commercial products from the area include sand, gravel, and water from the aquifer. Many gravel pit operations exist along the Great Miami River valley. A water company is located $2 \mathrm{~km}$ ( 1.25 miles) upstream of the site's effluent discharge to the river; presently. this company pumps about $76,0(0) \mathrm{m}^{3}(20$ million gallons) of groundwater per day, for sale primarily to Greater Cincinnati industries.

\section{Exposure Pathways to Humans}

To protect the local environment, the Environmental Monitoring Program focuses on exposture pathways. A pathway is a route by which materials could travel between the point of release and the point of delivering a radiation or chemical dose to a person. These pollutants may reach people directly via a primary pathwaly, through contaminated air or water, or through a secondary pathway, such as the food chain. One example of a secondary pathway is the air-to-soil-to-roots-to-produce-to-human pathway. In this scenario, a gas or dust particle released from a stack settles on a field or a plant and is absorbed into the soil. A plant may then absorb the pollutant through its roots; the chemical would then pass into the rest of the plant, including the edible portions.

This scenario presents a simplified pathway that materials may take. The actual route of the material can be very complex, and the quantity of material that could eventually reach people would be very small. To develop an understanding of the complexity, take another look at the pathway and consider that not all materials released settle out of the air; some fraction may be washed out by rain and enter surface water or groundwater. Of the fraction that does settle, not all falls onto fields, and not all of that fraction on fields is absorbed by the roots of plants. This process of dilution and separation continues until some small fraction of what is released in the air may reach the leaves or fruit of the plant. Although certain plants. animals. and soils may concentrate specific materials and are therefore important points in pathways that should be sampled, pathways frequently overlap, and it is difficult to trace them precisely. Environmental sampling and analysis are performed to detect the presence and concentration of pollutants throughout the air and liquid pathways.

Although both radioactive and nonradioactive materials can reach people through the same pathways, the pathway scenarios presented here and throughout the report will focus on radioactive contamination since this is of significant concern at the Fernald site. Much of this report. ats well as the Environmental Monitoring Program itself. focuses on radioactive contamination. Uranium is the major radioative pollutant at the site; however. some of the uranium processed was recycted from nuclear reactors and contains trace concentrations of tission products (such as 
strontium-90) and cesium-137) and transuranics (such as neptunium-237, plutonium-239. and plutonium-240)). These nuclides are radioactive, and the site monitors for them in air and liquid discharges to the environment. These trace radionuclides also exist in the environment as a result of fallout from weapons testing and emissions from other nuclear facilities.

To crganize the many pathways that exist, the Environmental Monitoring Program centers on two major pathways: air and liquid. These pathways provide a basis for the environmental sampling program and direct which environmental samples and models will be used in estimating dose. (Direct radiation, a third pathway, is monitored with radiation detection instruments that measure radiation emitted directly from the site, particularly from the K-65 silos. Direct radiation is discussed further in Chapter Four.) The following sections describe how materials may follow the air and liquid pathways and briefly describe environmental monitoring procedures.

\section{Air Pathway}

The air pathway includes not only all the airborne pollutants that may be carried from the Fernald site through emissions but also through direct radiation (see Figure 11). Stack and building vent emissions are obvious sources of pollutants, but dust from construction and remediation activities, waste handling, and wind erosion are also important potential sources. The form and chemical makeup of pollutants influence

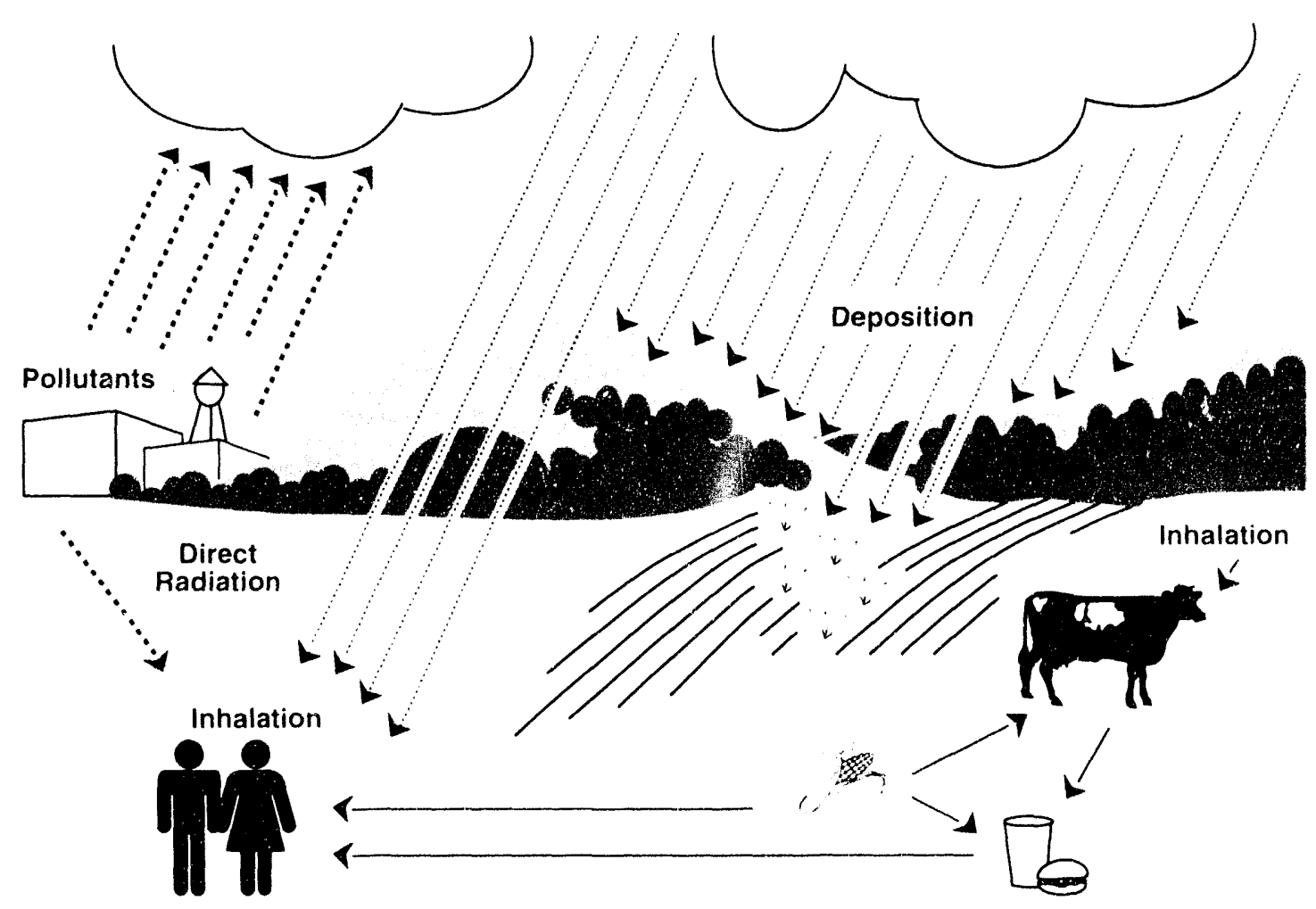


how they are dispersed in the environment as well as how they may deliver radiation doses. For example, line particles and gases may be inhaled, while larger, heavier particles tend to settle and deposit on grass or soil. Chemical properties determine whether the pollutant will dissolve in water, be absorbed by plants and animals, or settle in sediments and soils.

For the environmental scientist, the first step in monitoring the air pathway is to measure the concentration of the pollutants at the point of release, after they have gone through treatments and filtering. This provides preliminary information on how much pollutant is released and how it will behave in the environment. It is also possible to estimate the concentration of contaminants in the air once the emissions pass through the stack. The site operated 20) air monitoring stations 24 hours a day, seven days a week, during 1993 to monitor these air emissions.

\section{Liquid Pathway}

The liquid pathway includes all releases that could carry waterborne pollutants (see Figure 12). The principal liquid pathways include the effluent discharge line to the Great Miami River, the overflow spillway from the Stormwater Retention Basin. uncontrolled stormwater runoff, and groundwater. Just as with the air pathway, the first step in monitoring the liquid pathway is to sample the effluent streams as they leave the site. The potential dose that could be delivered via the liquid pathway can be estimated by the type and concentration of each pollutant. Some pollutants in the liquid effluent may be carried along as suspended solids. which eventually settle out as sediment in the stream bed; other pollutants are dissolved in the water and could be absorbed by plants and animals.

Sediment sampling in Paddys Run and the Great Miami River provides information on whether pollutants are accumulating in the stream beds. Fish sampling can show whether pollutants are being absorbed by aquatic animals and how much radioactive material could reach people if they eat fish from the Great Miami River. Fish are known as biological indicators because they can concentrate certain pollutants as they come into contact with them. Therefore, the longer-term influence of the Fernald site can be measured through fish sampling.

Groundwater is an important component of the liquid pathway because it is the source of water for homes and farms in the area. Extensive sampling of the wells on the site and in the surrounding area provides information about the aquifer. By sampling the aquifer in many locations and at varying depths, site personnel can determine the extent of any contamination.

Each pathway has specific standards and guidelines which define the allowable dose limits for the pathway, and these are discussed in the next section. 


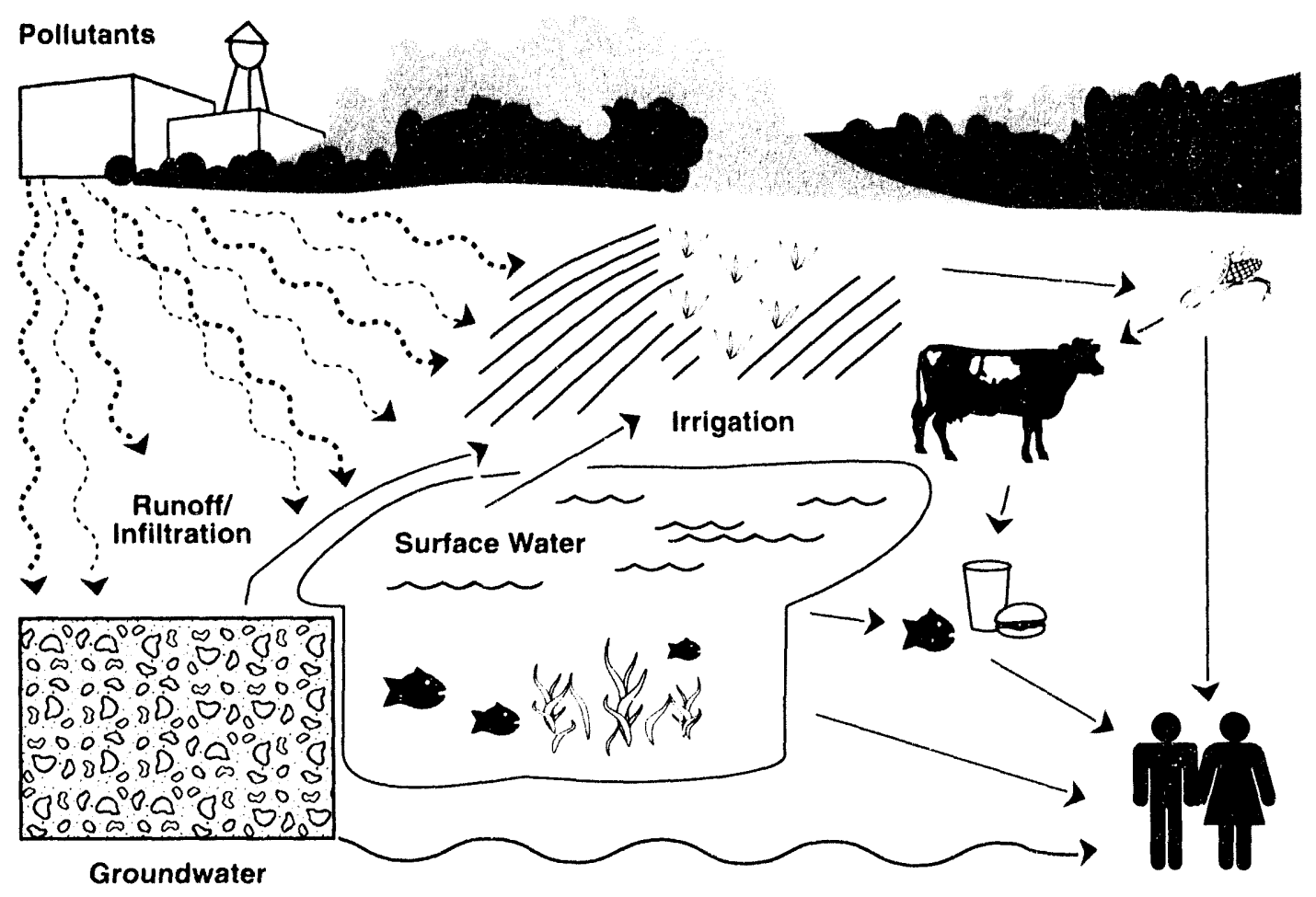

\section{Environmental Standards and Guidelines}

As part of data analysis, site personnel compare the data to established standards and guidelines whenever possible. These standards and guidelines have been established by numerous national and international scientific and government groups, including the National Council on Radiation Protection and Measurements (NCRP), the International Commission on Radiological Protection (ICRP), United States Environmental Protection Agency (USEPA), Ohio EPA (OEPA), and DOE.

These groups have studied the effects of radioactive and nonradioactive materials moving through the many environmental pathways lo people. From this information, standards and guidelines have been established to ensure that employees, people in the surrounding communities, and the environment are protected.

DOE adopts standards recommended by various groups of experts and publishes them in DOE orders, thereby establishing the recommendations as limits to be met by DOE facilities. For example, DOE Order 54(0).5, "Radiation Protection of the Public and the Environment," detines the guidelines for radiation exposure to the public based upon recommendations of the ICRP.9.11 Through reports and other 
guidance, the ICRP recommended a system of dose limits. Almost all countries with nuclear programs have adopted these recommendations, which provide a scientific basis for radiological protection and the selection of dose limits.

Once DOE publishes a standard in a DOE Order, such as 54(x).5, each DOE site must meet the limits of radiation exposure established in that order. These limits refer to the amount of exposure that a person beyond a facility's boundary could receive from breathing the air or drinking the water. The standards in DOE Order 54() .5 require that routine activities not cause a member of the public to receive an annual effective dose from all radioactive sources (except radon and its decay products) greater than 100 mrem. This dose. known as the primary dose limit, is in addition to natural background radiation (discussed in Chapter Two). Underlying all rules and requirements is the philosophy of keeping exposures As Low As Reasonably Achievable (ALARA). Therefore. DOE expects doses from its operations to be just a small fraction of the $1(0)$ mrem per year limit.

In addition to the requirements of the primary dose limit and the ALARA process, DOE is subject to several pathway and source-specific limits defined in other federal regulations. These imposed dose limits include, but are not restricted to, doses from the air pathway and from the liquid pathway. For example, the Clean Air Act states that the air pathway (air emissions and fugitive emissions from a facility) cannot contribute more than a 10 mrem effective dose in one year to a member of the public. Again, doses from radon and its decay products are covered separately." For drinking water, DOE operations cannot contribute more than a 4 mrem effective dose in one year to a member of the public. '?

DOE Order 54(0).5 also establishes guidelines for concentrations of radionuclides in air emissions and in liquid effluent. These concentrations, referred to as Derived Concentration Guidelines (DCGs), are initial screening levels that enable site personnel to review emissions and effluent data and determine if there is a need for further investigation.

The Fernald site follows these standards and guidelines in its daily operations and must provide monitoring results on a regular basis to DOE. USEPA, and OEPA in reports that include the following:

- Annual Radionuclide Air Emissions Report to DOE and USEPA.

- NPDES Monthly Discharge Monitoring Report to OEPA,

- Eftluent Information System/Onsite Discharge Information System to DOE, and

- Monthly Consent Agreement Report to USEPA. 
This SER compares the results of the site's monitoring program to specific standards for various pollutants. Some pollutants do not yet have standards and DC (is established. Furthermore, there are instances where standards do not exist for specific media, such as uranium in soil, grass. produce, or fish. Where no standards or guidelines are availatble, other points of reference are presented in order to help the reader assess the impact of Fernald site operations. For example, results are compared with background data from areas unaffected by the Fernald site activities. Results from 199.3 are also compared with results from previous years to look for trends.

The remainder of this report discusses some basic facts about radiation and other health hazards. compliance activities, and the Environmental Monitoring Program for 1993. 


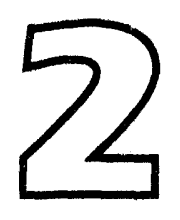

\section{Fundamentals of Radiation and Health Hazards}

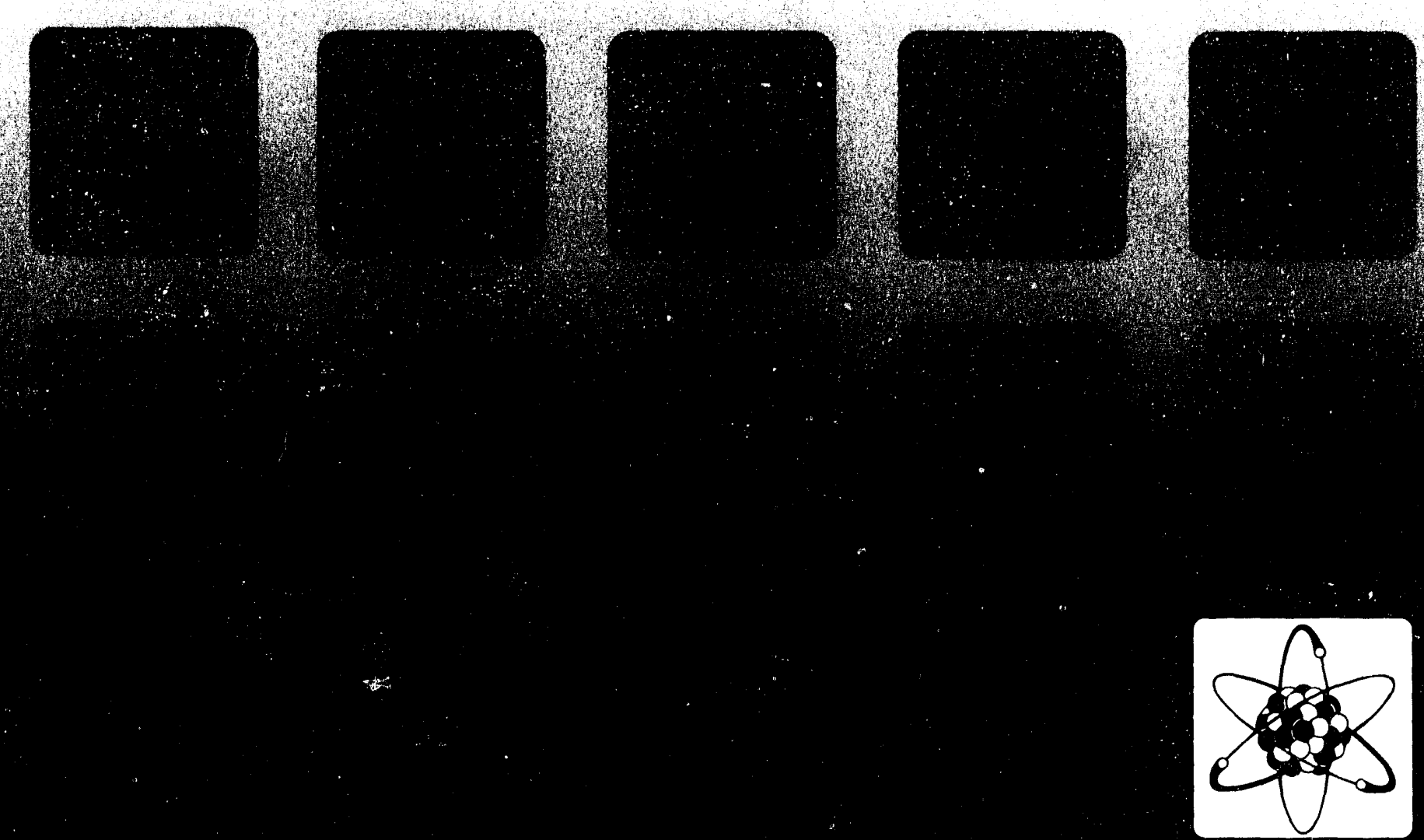




\section{Fundamentals of Radiation and Health Hazards}

Since radioactive materials and hazardous chemicals are stored at the Fernald site, it is important to understand the possible health hazards associated with these materials. Also, terms unique to radiation and its potential health effects are used extensively throughout this report. As a result, some of the important information in the report may be difficult for the non-scientist to interpret. This chapter provides a way to put that information into perspective and includes the following topics:

- The atom,

- Radioactivity and radiation,

- The units used to measure radiation,

- Background radiation,

- The effects of radiation,

- Definitions of terms,

- Laws regulating health hazards, and

- Types of health threats.

Readers who are already familiar with the concepts and terms used in the study of radiation and other health hazards may wish to proceed directly to the next chapter, the Environmental Compliance Summary. 


\section{The Atom}

The world is made up of atoms. Atoms consist of two basic parts:

- The nucleus, and

- The electrons orbiting the nucleus.

The nucleus is made up of protons, which are positively charged, and neutrons. which have no charge. Protons and neutrons are similar in sise, and both are considerably larger than electrons (about $1,8(x)$ times more massive). Therefore, the weight and mass of the atom is principally concentrated in the nucleus. The electrons circling the nucleus have a negative charge. Atoms tend to move toward a neutral state in which the negative electrical charge of the orbiting electrons balances the positive charge of the nucleus. To keep the atom electrically neutral, the number

\section{Figure 13: Structure of the Atom}
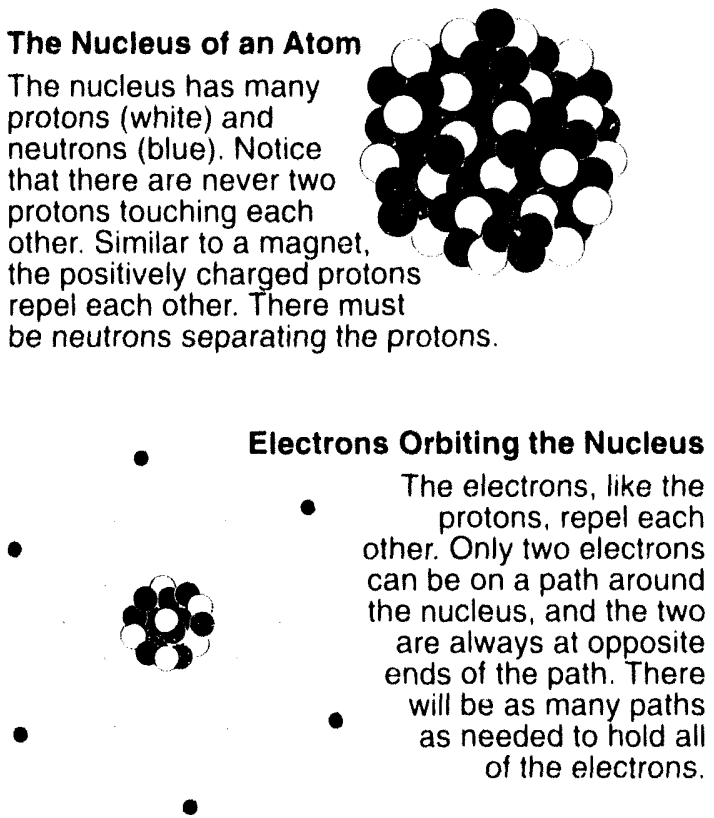

\section{The Hydrogen Nucleus}

The hydrogen nucleus always has one proton and can have zero, one or two neutrons. The protons are positive and the neutrons are neutral.

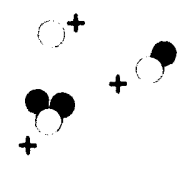
$\because$

The Hydrogen Atom The hydrogen atom consists of the nucleus and the electron orbiting the nucleus. Since the hydrogen atom has one proton, it must have one electron to be electrically neutral. of electrons in an atom must equal the number of protons (see Figure 1.3).

Protons and electrons have many characteristics similar to magnets. Just as opposite magnetic poles are drawn toward each other, protons and electrons alre attracted toward each other. This attraction keeps the electrons orbiting around the nucleus. The electrons are not pulled into the nucleus because of the electrons' energy. This energy keeps them constantly moving and away from the protons. The energy in the electrons and the attraction of the electrons to the protons balance each other and keep the electrons in orbit. Just as energy in the electrons keeps them orbiting, energy in the nucleus keeps the protons and neutrons together.

The number of protons in the nucleus is referred to ats the atomic number, and it is the identifier of the atom. If the atomic number changes, then the number of electrons and the chemical properties of the atom change. For example, for an attom to be hydrogen, it must have one proton. If a hydrogen atom were to gain a proton, it would no longer be hydrogen; it would be helium, which has two protons. Uranium, the substance of most concern at this site, hats 92 protons. Since protons are positively charged, the atom must also have 92 electrons for it 10 be electricually neutral. 
The sum of the protons and neutrons in the nucleus is called the mass number. Unlike protons, the number of neutrons contained in a specilic atom can vary since neutrons have no charge and do not need to be balanced by electrons. Therefore, the mass number can vary. For example, a hydrogen atom always has one proton. hut it can have either zero, one, or two neutrons. The different hydrogen atoms are called isotopes of hydrogen. Isotopes are labelled with their mass number. A hydrogen atom without a neutron is referred to as hydrogen-1 where 1 is the mass number. The hydrogen isotope with one neutron is referred to as hydrogen-2, and the isotope with two neutrons is referred $t(0)$ as hydrogen-3.

Most of the uranium at the Fernald site contains 146 neutrons to go with the 92 protons present in every uranium nucleus; therefore, the mass number is 238 (146 neutrons +92 protons $=238$ ). Uranium-234 has 142 neutrons +92 protons. uranium-2.35 has 143 neutrons +92 protons, and uranium-236 has 144 neutrons +92 protons. All isotopes of uranium are radioactive. Radioactivity and radiation are described in the next section.

\section{Radioactivity and Radiation}

Radioactivity is a process in which a nucleus of an unstable atom spontaneously decays or disintegrittes. Radiation is the energy that is released as particles or waves when the disintegration or decily of the nucleus occurs. This section includes a discussion of radioactive decay and the three main forms of radiation produced by radioactivity:

- Alpha particles.

- Beta particles, and

- Gamma rays.

It should be noted, however, that not all radioactive substances emit all three types of radiation. Some homeowners have expressed concern about receiving radiation from gamma rays due to the presence of uranium-2.38 in well water. However, uranium238 emits alpha particles. not gamma rays. The differences between alpha particles and gamma rays will be clarified in the discussions that follow.

\section{Radioactive Decay}

Atoms are radioactive because their nucleus is too large because of the number of protons and neutrons) or has too much energy to remain stable. By emitting radiation, the nucleus releases energy and moves toward a more stable. less energetic state and eventually becomes a stable atom. Radioactive decaly occurs everywhere on earth because of naturally occurring radioactive elements. When most radioactive elements decaly, the resulting atom is also radioactive. This is called a radioactive decay chain. There are four natural radioative decay chains. A common chain hegins with uranium-238 and ends with lead-206 (this isotope of lead is stable, 
which means it does not decay). Each of the various radioactive atoms (radionuclides) created during the decay sequence has its own natural rate of decay.

It takes a different amount of time for each element to decay to the next element in the chain. The amount of time it takes for a radioactive substance to lose half of its radioactivity, or for half to become the next element in the chain, is its half-life. All

\section{ADDRESSING HOMEOWNer CONCERnS ABOUT USES OF WELL WATER}

Several homeowners near the Fernald site have expressed concern as to why well water with low concentrations of natural uranium may be acceptable for household utility uses such as washing clothes, bathing, and watering plants, but may not be acceptable for drinking or cooking. To some, this has seemed an inconsistency and cause for misunderstanding.

The key to understanding why the water is acceptable for external uses is an understanding of how alpha particles, of prime concern when dealing with uranium, deliver a radiation dose. Apha particles are large, charged particles that readily interact with other materials. This interaction prevents the particles from ever penetrating very deeply. Even the most energetic alphas from uranium are stopped by the outer layers of dead skin.

However, inside the body, there are no protective dead cell layers to prevent the alpha particles from interacting with live organ cells; all emitted energy is delivered as dose to the organ. The alphaemitting radionuclide may also be incorporated into specific kinds of cells, depending on its chemical properties. For example, the body processes several radionuclides as though they were calcium; predictably, they end up being deposited in the bones. Research has shown that uranium tends to concentrate in the bone and, to a lesser extent, in the liver, kidneys, and other tissues.

There is also a chemical toxicity associated with uranium, in dependent of its associated radiation hazards. Studies on animals have indicated that uranium is toxic to the kidney at concentrations of approximately $70,000 \mathrm{pCi} / \mathrm{L}^{13}$

Athough the concentrations of concern in these studies are several thousand times greater than the concentration of ura nium in local groundwater, it is desirable to limit the intake of uranium. While no measurable increase in health effects can be expected by drinking water with slightly higher than typical background concentrations of uranium, decreasing the amount of uranium ingested may provide valuable peace of mind to those concerned. And, even with slightly higher uranium concentrations, the water is still acceptable for external, household utility use. decay chains found in nature begin with an isotope with an extremely long half-life. I! i- assumed that these atoms were formed at the same time as all the other atoms on earth and are still present because their half-lives are comparable to the age of the earth.

The uranium decay sequence is a common example in nature and here at the Fernald site. (The uranium and thorium decaly chains are presented on the following page.) Uranium-238 emits an alpha particle (two protons and (wo reutrons) and becomes thorium2.34. Then a neutron in thorium-2.34 becomes a proton and an electron. The electron is emitted as a beta particle. Then thorium-234 decays to protactinium-234. The decay process proceeds in this manner until the element becomes stable as lead-206. Much of the uranium and thorium at the Fernald site has been chemically purified and separated from other elements shown in the decay series. Elements separated from uranium and thorium are some of the wastes stored onsite. The material stored in the K-65 silos is an example of such waste. 


\begin{tabular}{|c|c|c|c|}
\hline \multirow{19}{*}{$\begin{array}{r}\text { Nuclides } \\
\text { of the Uranium } \\
\text { Decay Chain }\end{array}$} & Isotope & Half-life & Radiation \\
\hline & Uramum-238 & $4,500,000,000$ years & Alphis \\
\hline & Ihorum 234 & 24 days & bets, gammes \\
\hline & Protectunum-234m & 12 minutes & beter, grommet \\
\hline & Uranum-234 & 250,000 yedrs & alphet, gernmas \\
\hline & Thorrum-230 & 80.000 years & alphtat. Germmet \\
\hline & Radium 226 & 1,622 years & alphet extmmet \\
\hline & Ridom 222 & 38 detys & alphat \\
\hline & Polonium-218 & 305 minutes & . 11phts \\
\hline & Leted-214 & 26.8 mmutes & 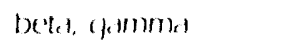 \\
\hline & Astrtine 218 & 20 seconds & alphtir \\
\hline & Bismuth-214 & 197 minutes & beted. g.tmmat \\
\hline & Polonium 214 & 0.000164 second & allpha, geammat \\
\hline & Thatlium-210 & 1.3 minutes & betc. gammet \\
\hline & $16 \operatorname{cod}-210$ & 22 years & beted. gatmm \\
\hline & Bismuth-210 & 50 delys & betat \\
\hline & Polontum-210 & 138 days & alphes gearmma \\
\hline & Thallium-206 & 42 minutes & beta \\
\hline & Lend 206 & Stable & none \\
\hline \multirow{13}{*}{$\begin{array}{l}\text { Nuclides } \\
\text { of the Thorium } \\
\text { Decay Chain }\end{array}$} & Isotope & Half-life & Radiation \\
\hline & Thorlum 232 & 14.000 .000 .000 years & alphat \\
\hline & Ractum 228 & 67 years & bew \\
\hline & Actinum 228 & 613 hours & betest. germmet \\
\hline & Thorumm- 278 & 19 yeirs & diphes ganmond \\
\hline & Radium 224 & 364 driys & alphet, gemmos \\
\hline & Reidon-220 & 55 seronds & .11phus \\
\hline & Polonum 216 & () 16 second & , Ilphet \\
\hline & $10 \cdot 1 d-212$ & 106 hours & beted. Getmment \\
\hline & Bismuth-212 & 605 minutes & 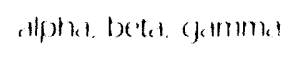 \\
\hline & Polonum-21) & $0000000304 \sec$ ond & atponat \\
\hline & The allum 208 & 31 mincutes & betal (jermmon \\
\hline & $16 \cdot 121208$ & Statte: & none. \\
\hline
\end{tabular}

EXAMPLE To illustrate the idea of half-life, let's look at the isotope thorium-234. Its half-ife is 24 days. If you started with 1,000 atoms of thorium-234, after 24 days you would have 500 . After another 24 days you would have 250 , and so on. The half-life of some isotopes, such as uranium-238, is very long. The middle column in the uranium and thorium decay chain examples contains the half-life periods of the elements in the decay chain. All the radionuclides in the Uranium Chain can be thought of as "potential" lead-206 atoms. This will be the case many billions of years into the future when all natural radioactive isotopes will have decayed to their stable end products. 


\section{Apha Particles}

Alpha particles consist of two protons and two neutrons and have a positive charge. Because they are charged. they interact with other atoms by scattering off other charged particles. thus losing their energy. Moreover. because of their large size. alpha particles do not travel very far when emitted (1 to 8 centimeters in air). They are unable to penetrate any solid material. such as paper or skin. to any significant depth (see Figure 14). However. if alpha particles are released inside the body. they can damage the soft internal tissues hecause they deposit all their energy in a very

\section{Figure 14: Types of lonizing Radiation}

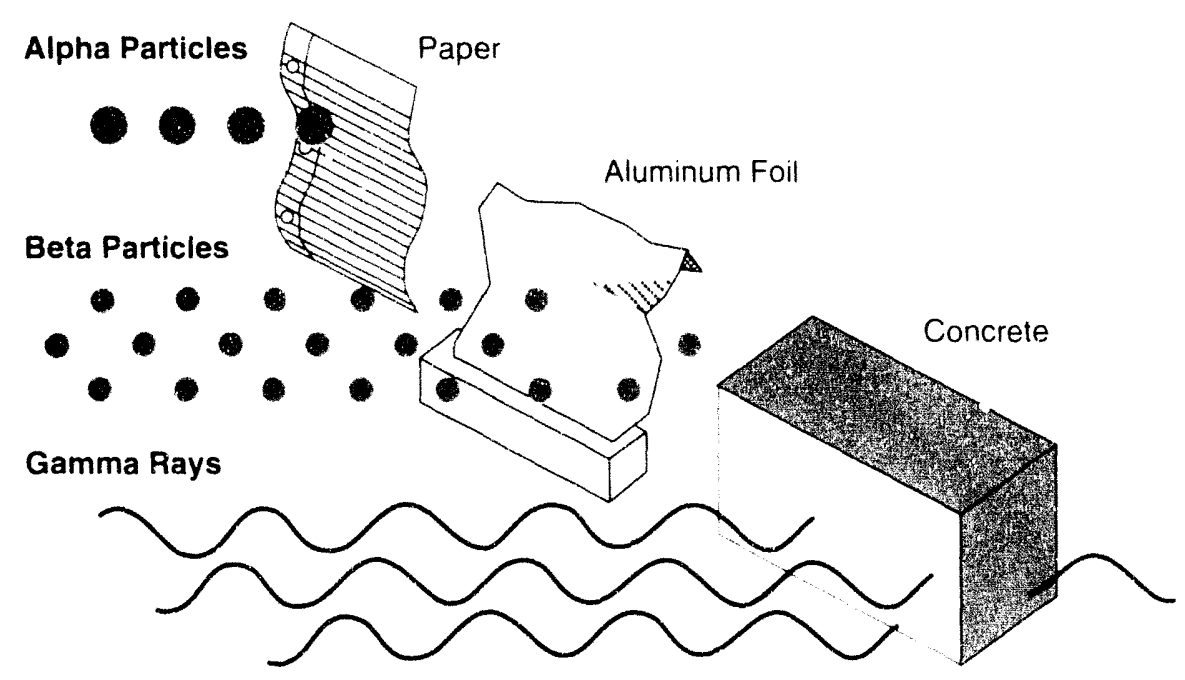
small volume. Uranium decays by emitting alpha particles, so if uranium particles are inhaled or swallowed. the emitted alpha particles may damage internal tissue Some other radionuclides present at the Fernald site that decay by emitting alpha particles include thorium-228, -230). and -232 .

\section{Beta Particles}

Beta particles are electrons that carry at negative electrical charge. They are much smaller than alpha particles and travel at nearly the speed of light: thus. they can travel approximately 2 to 4 meters 16 to 12 feet $)$ in air and penetrate solid materials about $1 \mathrm{~cm}(0)+$ inch). Beta particles interact with other atoms in ways similar to alpha particles. hut since they are smaller, faster. and have less charge. they cause less concentrated damage when interacting with tissue. Thorium-234. a decay product of uranium-238. emits heta particles.

\section{Gamma Rays}

Gammat rays are hundles of electromagnetic energy which behave as though they were particles. These peede-particles are called photons. They are similar to visible light. hut of a much higher energy. For example. $X$-rays are a type of high-energy electromagnetic radiation. and excessive exposure $6 x$-rays can damage the body. Gamma ray are generally more energetic than $X$-rays. They can tratel long distances and can penetrate not only skin. but. depending on their energy. can penetrate 
substantial distances into solid materials such as concrete or steel. Gamma rays are often released during radioactive decay along with alpha and beta particles. Some of the materials stored in the K-65 silos decay by emitting gamma rays. Potassium-40) is an example of a naturally occurring radionuclide found in all human tissue that decays by emitting a relatively high-energy gamma ray. The typical human body contains about $110.0(0)$ picocuries of potassium-40. (Units of radiation are discussed below.)

\section{Interaction with Matter}

When radiation interacts with other materials, it affects the atoms of those materials principally by knocking the negatively charged electrons out of orbit. This causes the atom to lose its electrical neutrality and hecome positively charged. An atom that is charged. either positively or negatively. is called an ion. Anything that creates an ion is said to be ionizing.

\section{Units of Measurement}

To measure the effect of radiation. scientists have developed ways to measure levels and intensity of radiation. Some of these measurement units are technical and may require some explanation. Additional terms are included in the glossary of this report.

\section{Activity}

Activity is the number of nuclei in a material that decalys per unit of time. An amount of radioactive material that decays at a rate of 37 billion atoms per second has an alctivity of one Curie (Ci). Smaller sub-units of the Curie are often used in

Figure 15: Comparison of Disintegration Rate*

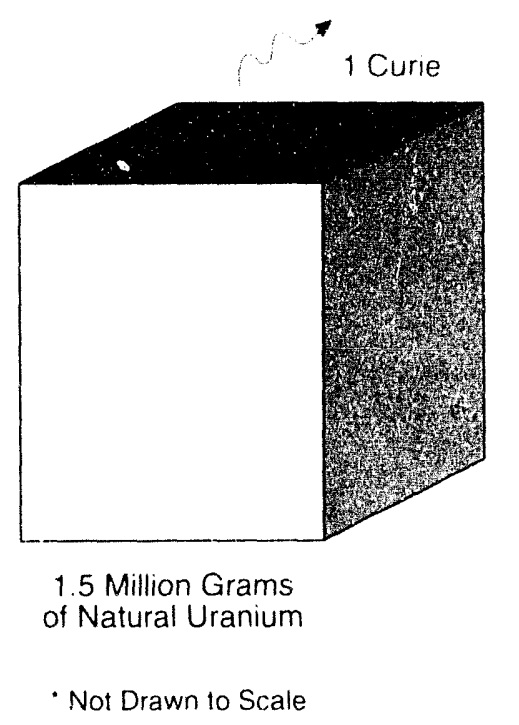

this report. Two common units are the microcurie $(\mu \mathrm{Ci})$. one millionth of a Curie. and the picocurie (pCi). one trillionth of a Curie. The amount of radioactive material required to emit one Curie depends on the disintegration rate. For example, about one gram of radium-226, with a hall-life of 1.622 years, is one Curie of activity. On the other hand. it would require about 1.5 million grams of natural uranium. which has a half-life of 4.5 billion years. to equal one Curie because natural uranium is less radioactive than ratdium-226. Radon-222, with a half-life of only 3.8 days, is even more radiouctive than radium-226. and only (0.00)(0)(6.5 gram of radon-222 is needed to equal one Curic (see Figure 15). 


\section{Dose Equivalent}

When a person comes into contact with radiation, that person has been exposed to radiation. Dose equivalent is a measure of the amount of radiation that is delivered to the body. Alpha, beta, and gamma radiation affect the body to different degrees. To take these different effects into account, each type of radiation is assigned a quality factor $(\mathrm{QF})$. The more damaging the type of radiation, the higher the $\mathrm{QF}$. For beta and gamma radiation, the $\mathrm{QF}$ is one. For alpha radiation, the $\mathrm{QF}$ is 20 . The $\mathrm{QF}$ number is multiplied by an absorbed dose to calculate an exposed person's dose equivalent. Dose equivalent, or simply dose, is used when comparing the effects of different types of radiation. The Roentgen equivalent man (rem) unit is used to express dose equivalent. The more rem, the higher the potential damage. Since the amount of radiation we receive from background and the Fernald site is so small, millirem (mrem) is often used instead of rem. One mrem is equal to $1 / 10(0)$ of a rem.

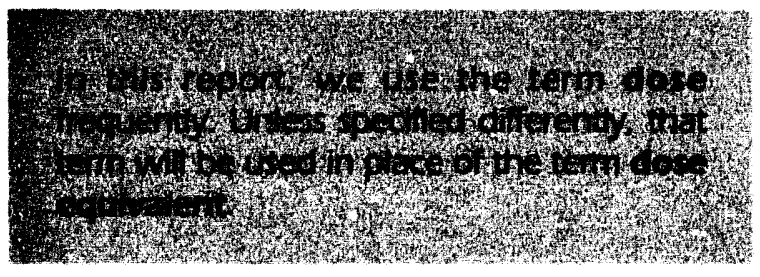

The term dose is used in four different ways in this report: organ dose, effective dose, committed effective dose, and whole body dose.

The organ dose is the amount of radiation received by an individual organ in the body. The amount of radiation any ds upon a variety of factors (for example, the way the radiation entered the body and the type of radiation). Therefore, when discussing the organ dose, scientists often refer only to the organ of greatest importance called the critical organ. The critical organ varies from situation to situation. It is determined based on things such as the amount of radiation received, the chemistry of the radionuclide, the sensitivity of that organ to the particular form of radiation, and the importance of that organ to the body. Based on the radionuclides found onsite. scientists have identified the critical organs as the lung, kidney, and bone surface (endosteum). Figure 16 shows which organs are most affected by various substances found at the site.

The effective dose expresses how much of a health risk radiation doses pose to individuals. To determine the effective dose, scientists first estimate each organ dose. Then, since some organs are more sensitive to radiation than others, the organs are given different weighting factors, similar to quality factors. The greater the risk an organ has of developing cancer and the more important that organ is to human health. the higher the weighting factor. The weighting factor is multiplied by the organ dose for each organ. These numbers are then added together to give the effective dose.

The NCRP and ICRP recommend that an individual be exposed to no more than I()) mrem effective dose per year for all pathways (over and above the amount a person receives from background and medical radiation). This recommendation applies to the general public for long-term. continuous exposures. ${ }^{\text {t }}$ The DOE guideline for 
Figure 16: Organs Affected by Substances Found at the Fernald Site

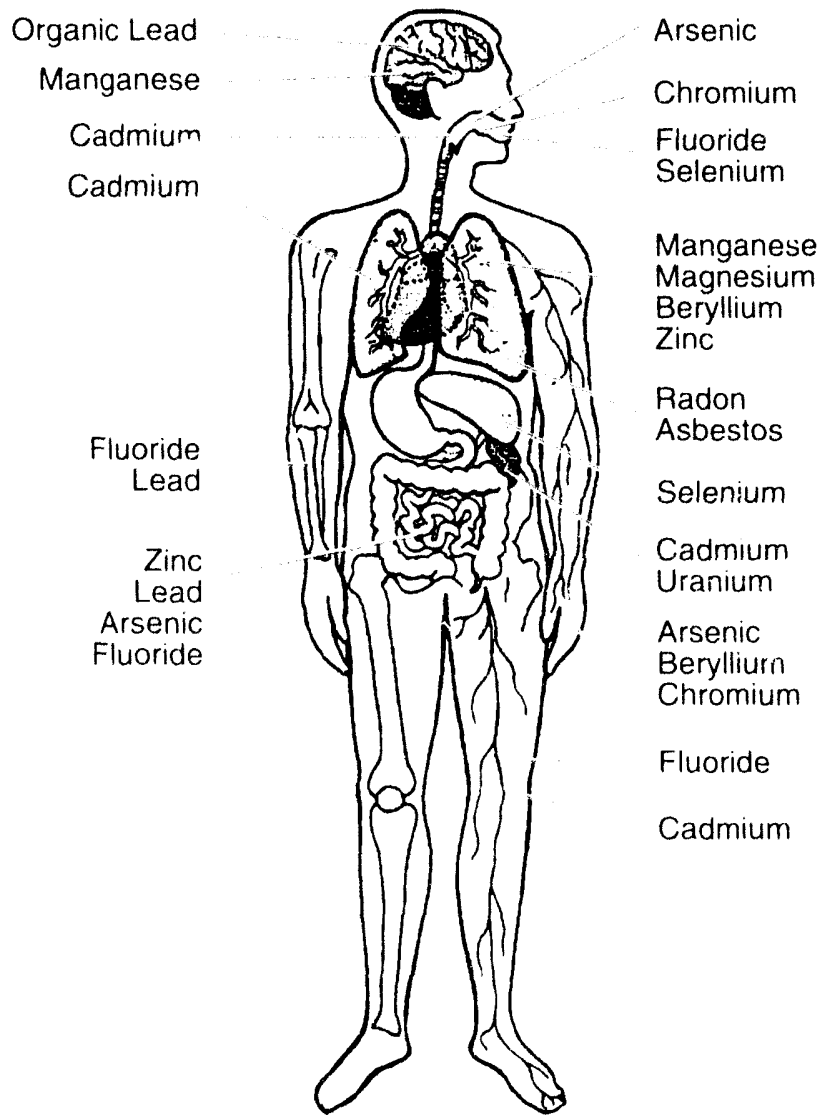

dose to members of the public is $1(0) \mathrm{mrem}$ per year from all pathways (excluding radon). The National Emission Standards for Hazardous Air Pollutants (NESHAP) limit for effective dose is 10 mrem per year from radionuclides (except radon) released via the air pathway."

The committed effective dose is the total amount of radiation an individual receives over a specified period of time from radioactive materials inside the body. When a person breathes or eats something that contains radioactive materials, the radiation within those materials is not all released at once. Half of the radiation is released over a period of time equal to the half-life of the radicactive material. Meanwhile, the body excretes radioactive materials at various rates determined by the individual 's metabolism and the biochemistry of the radioactive material. Scientists have developed the concept of the committed effective dose to estimate the total amount of radiation one will receive over time (generally a 50 )-year period) from the radioactive materials taken into the body in a given time period.

The whole body dose is the amount of radiation an individual receives when the entire body is irradiated evenly by direct (gamma) radiation. Most radionuclides present at the Fernald site do not contribute toward a whole body dose because they concentrate more in some organs than others and do not emit significant amounts of gamma radiation.

\begin{tabular}{|c|c|c|}
\hline Organ or Tissue & Welghting Factor & \multirow{8}{*}{$\begin{array}{l}\text { "Remainder" means the five other or- } \\
\text { gans with the highest dose (e.g., liver, } \\
\text { kidney, spleen, thymus, adrenal, pan- } \\
\text { creas, stomach, small intestine, or upper } \\
\text { and lower large intestine, but excluding } \\
\text { skin, lens of the eye, and extremities). } \\
\text { The weighting factor for each of these } \\
\text { organs is } 0.06 \text {. }\end{array}$} \\
\hline Gonads & 0.25 & \\
\hline Breasts & 0.15 & \\
\hline Red Bone Marrow & 0.12 & \\
\hline Lungs & 0.12 & \\
\hline Thyroid & 0.03 & \\
\hline Bone Surfaces & 0.03 & \\
\hline Remainder & 0.30 & \\
\hline
\end{tabular}




\section{Exposure to Background Radiation}

The dose terms defined in the preceding paragraphs apply to more than just the radiation we may be exposed to from facilities like the Fernald site. All people are constantly exposed to other background and man-made sources of radiation. Such radiation includes the decay of radioactive elements in the earth's crust, a steady stream of high-energy particles from space called cosmic radiation, naturally occurring radioactive isotopes in the human body like potassium-40, medical procedures, man-made phosphate fertilizers (phosphates and uranium are often found together in nature), and even household items like televisions. ${ }^{15}$ In the United States, a person's average annual exposure to background radiation is $360 \mathrm{mrem} .^{14}$ The DOE guidelines (as well as other radiological guidelines) apply to exposures individuals receive in addition to background radiation and medical procedures.

As the Exposure to Background Radiation Chart shows, radon is the largest contributor to background radiation (see Figure 17). At an average of 200 mrem per year, naturally occurring radon accounts for more than half of the background dose in the United States. "' (Radon is discussed further in Chapter Eight.)

Background radiation dose will vary in different parts of the country. For example, living in the Cincinnati area will produce an exposure level of approximately 110 mrem, while the dose received annually from living in Denver is approximately 125

Figure 17: Exposure to Background Radiation

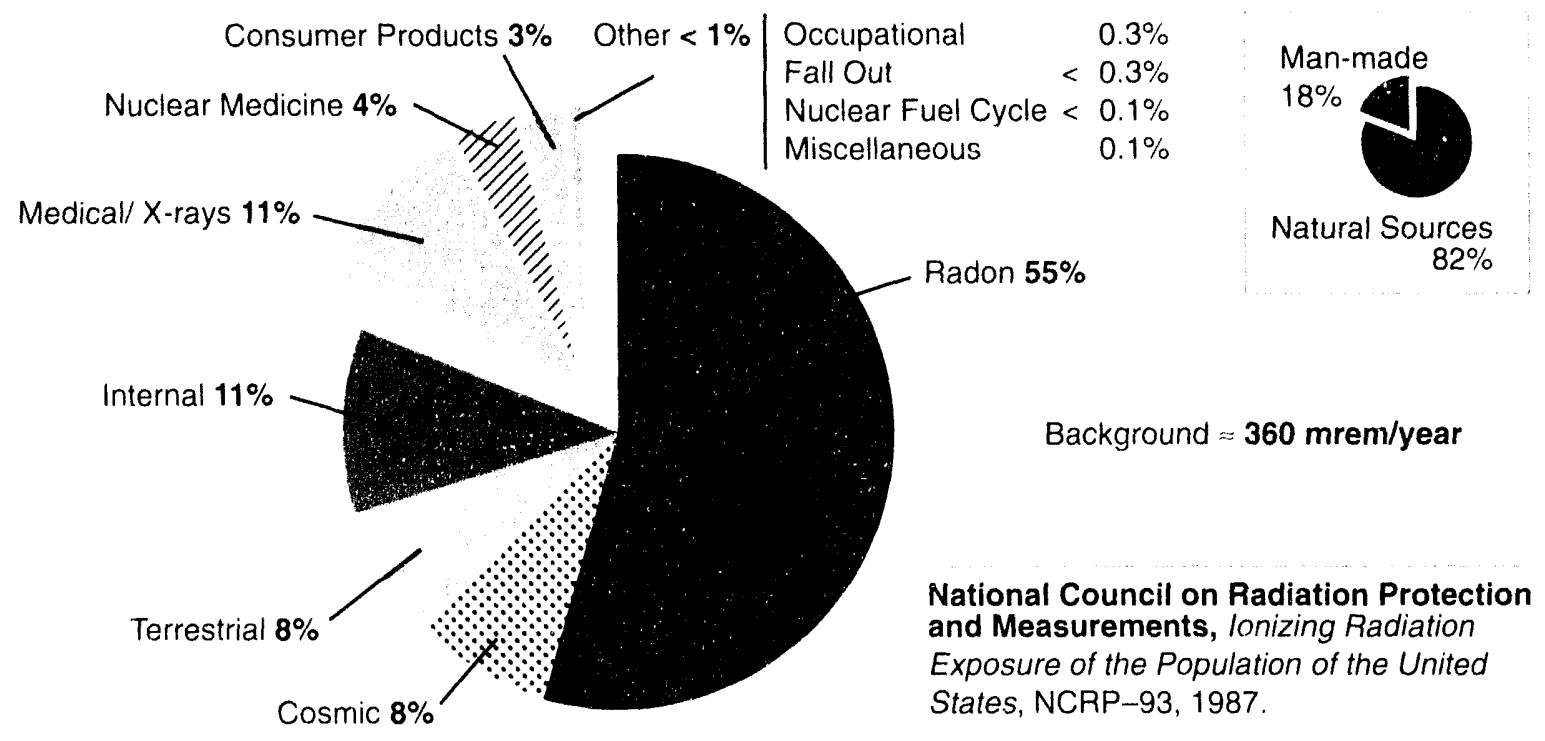


Figure 18: Breakdown of Average U.S. Radiation Exposures

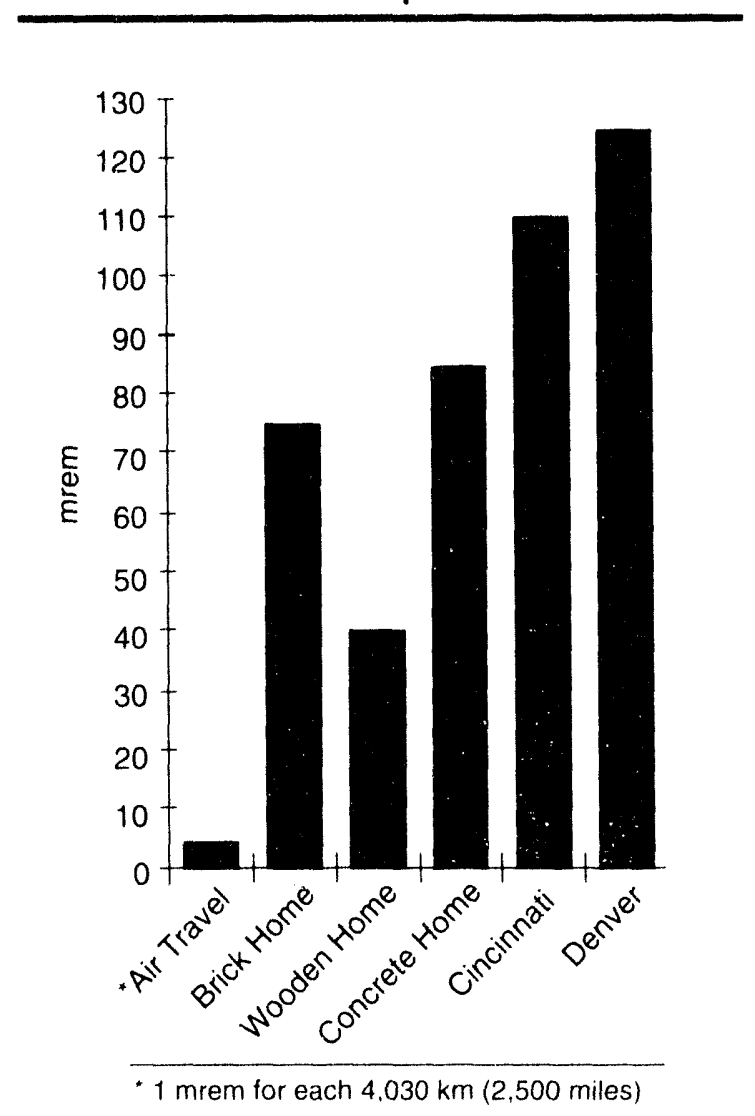

mrem. This difference can be attributed to soil composition and distance above sea level. Another factor which affects annual radiation dose is the type of building material used in homes. Figure 18 shows that the annual dose received from living in a brick or concrete house is about two times greater than from living in a wood frame house. Also shown in the bar chart is that a single round trip flight from Cincinnati to London (or the equivalent) produces an exposure of approximately $4 \mathrm{mrem}^{16}$ In comparison, the dose received at the site's fenceline from an entire year is approximately 1.0) $\mathrm{mrem}$.

One way to measure how much radiation we are exposed to is to complete a personal radiation dose worksheet, like the one on the next page. The next section provides information on the effects of low-level radiation, whether it is naturally occurring or originates from a facility like the Fernald site.

\section{Effects of Radiation}

The effects of radiation on hunans are divided into two categories, somatic and genetic. Somatic effects are those that develop in the directly exposed individual. including a developing fetus. Genetic effects are those that are observed in the offspring of the exposed person.

Because we are constantly exposed to both natural and man-made sources of radation, and because the body has the capacity to repair damage from low levels of radiation, it is extremely difficult to determine the effects from low-level radiation. This section explains why this is true and how somatic and genetic effects maly occur. 
Personal Background Radiation Dose Worksheet*

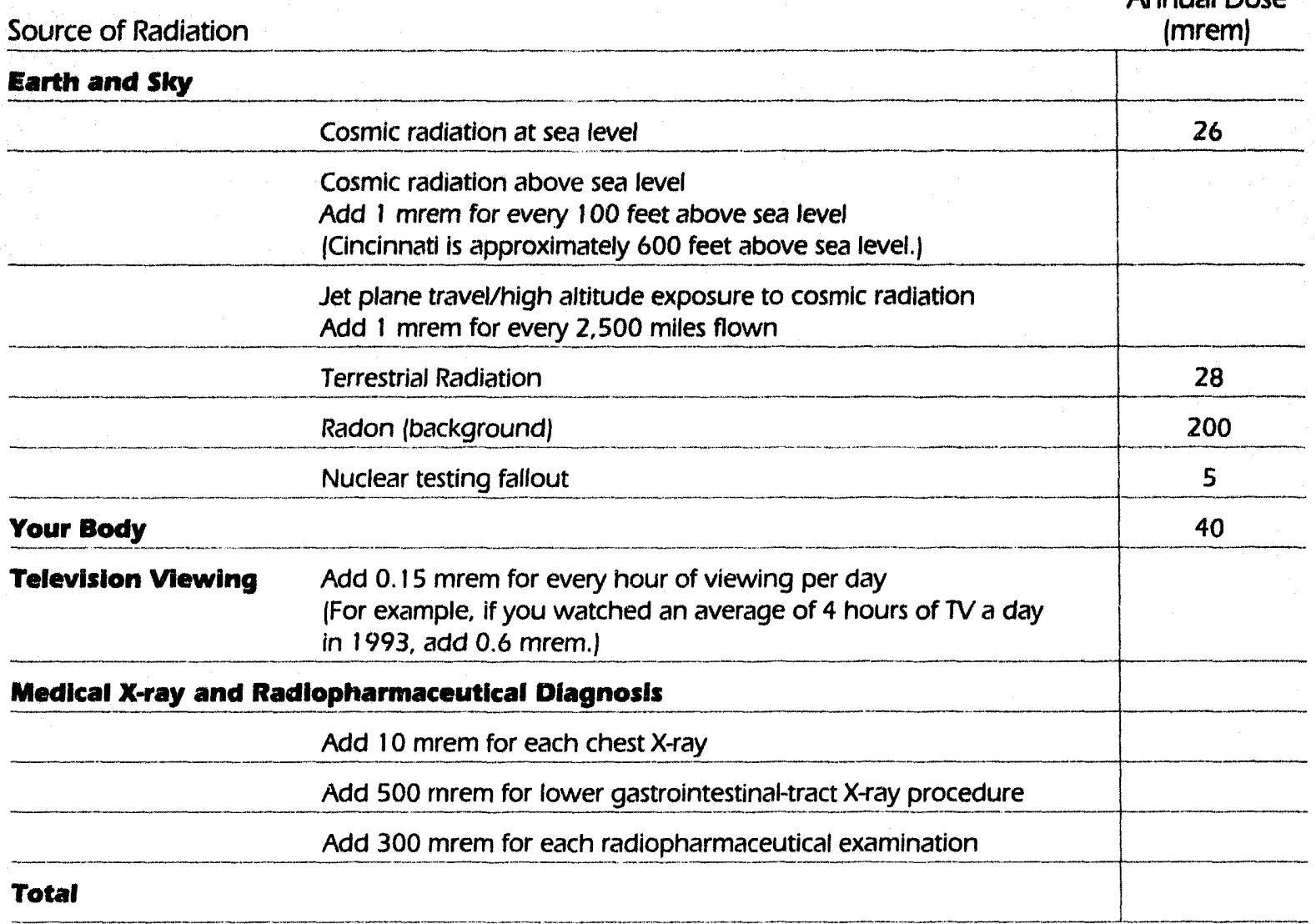

* The information is drawn from two major sources:

- BEIR Report-III-National Academy of Sciences, Committee on Biological Effects of lonizing Radiations, "The Effects on Populations of Exposure to Low Levels of lonizing Radiation," National Academy of Sciences, Washington, DC, 1980, and

- National Council on Radiation Protection and Measurements Report No. 93, 1987.

\section{Somatic Effects}

Continuous exposure to low levels of radiation can produce gradual somatic changes over extended time. For example, someone may develop cancer from man-made radiation, background radiation, or some other source not related to radiation. Because all illnesses caused by low-level radiation can also be caused by other factors, it is presently impossible to determine individual health effects of low-level radiation. However, there are a few groups of people under medical observation because they have been exposed to higher levels of radiation. These include the survivors of Hiroshima and Nagasaki, uranium miners in the United States and eastern Europe, a group of workers who used paint containing radium, carly users of $X$-ray machines, some DOE employees working in the defense facilities, and people suffering from illnesses where radioactive material was used for treatment. 
Even after studying the health effects of radiation on these groups of people, scientists are still not able to determine with certainty how much cancer, if any, may have heen caused hy low-level radiation.

Those individuals exposed to high levels of radiation are at greater risk. We know this because at these higher radiation doses, we see that the number of radiation effects increases as the level of radiation dose increases.

A whole-body dose of $1,(0)(\mathrm{rem}$ of radiation delivered instantaneously will probably kill a person. A dose of $6(x)$ to $1,()(0)$ rem causes severe sickness. but there is some chance for recovery. A dose of $2(0)$ (o $6(x)$ rem causes some sickness with a very good chance for recovery. A dose of $1(0)$ (1) 200 rem could possibly cause some vomiting. but probably no demonstrable long-lasting effects. ${ }^{17}$

Significant clinical symptoms of radiation probably will not be seen in individuals who have been exposed to less than $1(0)$ rem. ${ }^{1 \times}$ (The dose to the maximally exposed individual from all pathways, except radon. was approximately 1.0 mrem in 1993.) Most scientists believe that there are no direcily observable short-term radiation effects on human heings exposed to less than 10 rem because the biological damage created by this level of radiation is too small to result in near-term clinical symptoms.

Estimates on the value of the threshold level for radiation effects. if such a level exists, vary significantly. As mentioned above, some scientists believe it could be as high as 10 rem. ${ }^{17}$ Others insist there is no threshold level below which radiation exposure is safe. "They feel there is always a direct relation between the amount of radiation to which people are exposed and the number of related radiation effects.

Somatic effects have been documented only at high radiation levels. These include clouding of the lens of the eye. lowered fertility rate, and a reduced number of white cells in the blood. Problems caused by radiation seen in the development of the embryo result from large doses, not the low levels characteristic of background radiation. Therefore, the most likely somatic effect of low-level radiation is believed to be a small increased risk of cancer. ${ }^{15}$

\section{Genetic Effects}

A single ionizing event has the potential to cause a genetic effect. To understand why this is true, it is helpful to look at the structure of a human cell.

Human cells normally contain 46 chromosomes-23 transmitted from the mother and 2.3 from the father. These 46 chromosomes contain about $10,(0)(0)$ genes which are passed on to the next generation and determine many physical and psychological characteristics of the individual. 
Radiation can cause physical changes or mutations in these genes. Chromosome fibers can break and rearrange, causing interference with the normal cell division of chromosomes by affecting the number and structure. A cell can rejoin the ends of a broken chromosome, but if there are two breaks close enough logether in space and time. the broken ends from one break may join incorrectly with those from another. This can cause translocaltions, inversions, rings, and other types of structural rearrangement. "Radiation is not the only mechanism by which such changes can occur. spontaneous mutations and chemically induced mutations have been observed.

The mutated genes from one parent can then be passed on to offspring. They typically have no effect on the offspring as long an the genes from the other parent are not mutated in the same way. However. the genes stay in the body of the offspring and are passed on to following generations. If they meet similar genes when reproducing. they would then become present in the characteristics of the offspring. ${ }^{17}$

There is no evidence that there are radiation levels below which chromosomes are not affected: however, genetic effects of radiation have never been clearly demonstrated to occur in people. ${ }^{21 .} 21$

\section{Health Hazards at the Fernald Site}

Aside from radiation and its effects, there are other health hazarch associated with the Fernald site. In order to understand these other health hazards, it is helpful to be familiar with the terminology and laws that define and regulate these hazards.

\section{Definitions of Terms}

Many terms refer to substances that are subject to regulation under one or more federal environmental laws. State laws and regulations also provide similar terminology that may be confused with the federally defined terms. Many of these terms appear to be synonymous and are casily confused.

A hazardous chemical, as defined by OSHA, is any chemical which is a physical hazard or a health hazard. Physical hazards include combustible licpuids. compressed ganes, explosives, flammables, organic peroxides, oxidizers, pyrophorics. and reactives. A health hazard, on the other hand, is any chemical for which there is good evidence that acute or chronic health effects occur in exposed people. Among the list of havardous chemicals are carcinogens, irritants. corrosives, neurotoxins, and agents that damage the lungs, skin, eyes, or mucous membranes.

A hazardous material. as defined by the Department of Transportation, is a substance or material in a yuantity and form which may pose an unreasonable risk to health and silfety or property when transported in commeree. A Hazardous Materials Table, with more than $16 .(0)($ ) entries, includes explosives, oxidizing materials. 
corrosives, flammables, gases, poisons, radioactive substances, and agents capable of calusing discase.

A hazardous substance is any substance designated under Section 311 of the Clean Water Act: any element, compound, mixture, solution, or substance designated as hazardous under Section 102 of CERCLA; any listed or characteristic RCRA hazardous waste; any toxic or pollutant listed under Section 307 of the Clean Water Act; any hazardous air pollutant listed under Section 112 of the Clean Air Act: and any imminently hazardous chemical substance or mixture subject to Section 7 of the Toxic Substances Control Act.

A hazardous waste is a solid waste that must be treated, stored, transported, and disposed of in accordance with applicable requirements under Subtitle C of RCRA. Hazardous wastes may cause or significantly contribute to an increase in mortality or an increase in serious irreversible, or incapacitating reversible. illness. These kinds of wastes may also pose a substantial present or potential hazard to human health or the environment when improperly treated, stored, transported, or disposed of, or otherwise managed. Hazardous wastes are either listed in the regulations promulgating RCRA or are "characteristic" wastes. "Characteristic" hatzardous wastes include those that are ignitable, corrosive, reactive, or toxic. All RCRA Subtitle C listed or characteristic hatzardous wastes are also CERCLA hazardous substances."2

\section{Laws Regulating Health Hazards}

Some of the federal laws that regulate health hazards are discussed below. The first. CERCLA, provides for the remediation of havardous substances at National Prioity List (Superfund) sites. As well. CERCLA has its own reporting and response requirements when a hazardous substance released to the environment exceeds a reportable quantity.

RCRA Subtitle $C$, as discussed above, provides for the safe treatment and disposal of hazardous waste and regulates hazardous waste management practices for generators, transporters, and owners and operators of treatment, storage, and disposal facilities.

Section 6 of TSCA authorizes USEPA to initiale civil actions regarding hazardous chemical substances or mixtures which present an imminent and unreasonable risk of serious or widespread injury to health or the environment. There is no "list" of imminently hazardous chemical substances or mixtures, but USEPA currently regulates PCBs, fully halogenated chlorofluoroalkanes, asbestos, and hexalvalent chromium under Section 6 of TSCA.

Under the Clean Air Act, National Emission Standards for Hazardous Air Pollutants (NESHAP) are established. There are many hazardous air pollutants, including asbestos, ben/ene, heryllium, coke oven emissions, inorganic arsenic, mercury, radionuclides, and vinyl chloride. 


\section{Types of Health Threats}

There are many types of potential health threats (aside from the radioactive risks already discussed) related to the hazardous substances at the site. They should all be addressed and understood by both area residents and onsite workers so the substances will be handled properly and safely or avoided whenever possible. Carcinogens, corrosives, explosives, flammables, irritants, and poisons/toxins are all potentially harmful.

Carcinogens are substances that have the potential to catuse cancer. A common carc inogen located at the Fernald site is asbestos. When ashestos particles are inhaled into the lungs, they may damage the alveoli (the air sacs lining the lungs). This damage makes the lungs more susceptible to cancer, especially in smokers.

When a chemical causes a substance to wear away or deteriorate, it is said to be corrosive. Many common chemicals are potentially corrosive. For example, vapors from ammonia may be corrosive to the eyes, respiratory system, and other moist tissues. Blindness may result from a large exposure to these vapors.

Explosions can occur in many situations. If an unstable solid or liquid changes suddenly into a quickly expanding gas, especially in a tightly closed container, an explosion can occur. Rapid nuclear fission may also cause a substance to explode. During these explosions. energy is released, often in the form of heat and sometimes radiation. This energy release may cause injury resulting from the impact of debris or burns to exposed skin.

Flammable materials are any materials which can be easily set on fire and burn readily. Paints, gases, and fuels are common flammable mater als at the site. Hydrogen. for example, is a very flammable gas. An obvious health hazard associated with 17ammable material is the potential for burns.

An irritant is a substance which causes an organ or any part of the body to become inflamed or sore. A common solvent used at the site, 1,1,1-trichloroethane, can be an irritant to the skin and the eyes upon contact.

Poisons and toxins are substances that may cause illness or death when ingested or absorbed into the hody. Nearly all chemicals have the potential to become poisonous or toxic when used improperly or in excessive amounts. A toxin that destroys nerves or nervous: tissue is called a neurotoxin.

The next chapter, "Environmental Compliance Summary," presents the Fernald site's status with several environmental regulations. The environmental monitoring data are presented in chapters Four. Five, and Six. Chapter Seven presents a discussion of the estimated radiation doses to which the people near the site might be exposed and how these results were calculated. Tht,1, in Chapter Eight, the Radon Monitoring Program is discussed, and the 1993 radon monitoring and dose results are presented. 


\section{Compliance Summary \\ Environmental
Compliance Summary}

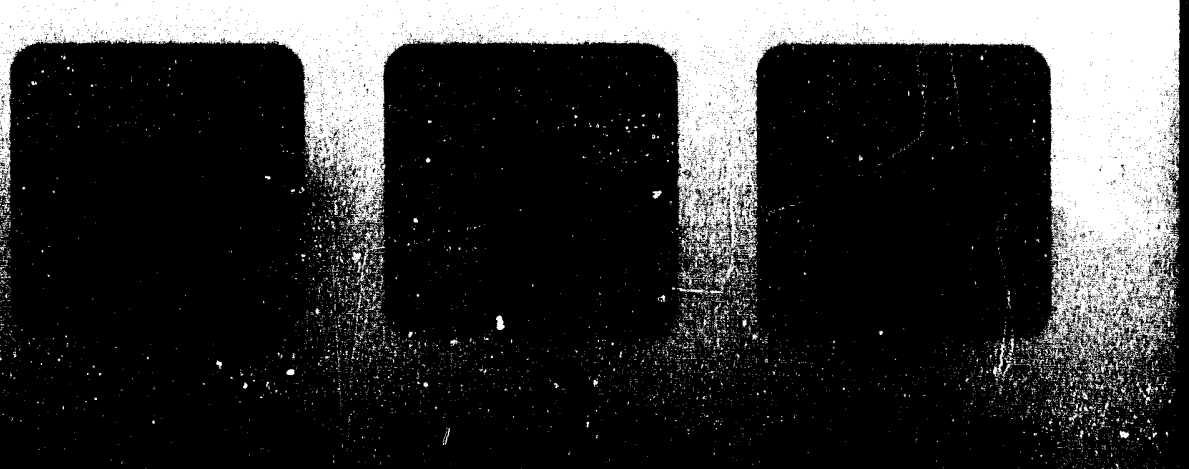

植 


\section{Environmental Compliance Summary}

The Fernald site must comply with environmental requirements established by a number of agencies governing daily operations at the site. These requirements fall into four general categories:

- Requirements imposed by federal statutes and regulations,

- Requirements imposed by state and local statutes and regulations,

- Requirements imposed by DOE Orders and directives, and

- Site-specific requirements imposed through agreements with regulatory agencies.

Because these requirements are initiated by several different sources, enforcement likewise falls under several federal, state, and local agencies. OEPA is the primary agency that issues permits, reviews compliance reports, inspects facilities and operations, and oversees compliance with applicable regulations. USEPA Region V governs the Comprehensive Environmental Response, Compensation, and Liability Act (CERCLA) process with the cooperation and active participation of OEPA. In addition, USEPA develops, publishes, and enforces environmental protection regulations and technology-based standards as directed by statutes passed by Congress. For some programs, USEPA has authorized the State of Ohio so that the regulatory program is enforced in lieu of the federal oversight. For these programs, OEPA promulgates state regulations which must be at least as stringent as the federal requirements and may exceed the federal requirements. The site is also subject to several legal agreements with USEPA Region $V$ and OEPA. DOE Headquarters issues directives to its field offices and conducts compliance audits. In addition, the Fernald site conducts internal audits.

The Fernald site's progress toward achieving full compliance with all environmental regulations is summarized in this chapter. It is divided into two main sections - "Compliance Status" and "Current Issues and Accomplishments." Additionally, the status of several environmental permits is discussed within the appropriate regulatory categories. This summary covers calendar year 1993 as required by DOE reporting requirements. 


\section{Compliance Status}

This section presents a summary of the Fernald site's compliance status with respect to federal and state envirommental regulations.

\section{CERCLA}

The Fernald site is on the National Priorities List (NPL) of sites requiring environmental cleanup under the Comprehensive Environmental Response, Compensation. and Liability Act (CERCLA), as amended. Consistent with the requirements of Section 120 of CERCLA. a Consent Agreement was signed by DOE and USEPA in April 1990) which oullined activities and schedules to be performed in order to remedy the site condition. This agreement was amended in September 1991. Collectively, the Consent Agreement and the Amended Consent Agreement (ACA), jointly referred to as the ACA. established the following operable units to more effectively manage the ongoing CERCL.A cleanup:

- Operable Unit I (OUI) - Waste Pit Area.

- Operable Unit 2 (OU2) - Other Waste Units.

- Operable Unit 3 (OU.3) - Former Production Area.

- Operable Unit 4 (OU4) - Silos 1 - 4.

- Operable Unit 5 (OU15)-Environmental Media, and

- Sitewide Operable Unit - A comprehensive unit encompassing operable units I through 5 to ensure that actions taken under the individual operable units are protective of human health and the environment on a sitewide basis.

The ACA provided new schedules for the completion of the ongoing Remedial Investigation and Feasihility Study (RI/FS) activities for each operable unit; initiated removal actions, which are tasks undertaken to abate immediate threats to the environment and health; and provided a mechanism for the site to add additional removal actions on a yearly hasis.

Additionally, the ACA. which establishes a CERCLA milestone compliance schedule agreed upon by both USEPA and DOE, required the completion of the following RI/FS activities in 1993:

- The submittal deadline for the OUI RI Report/Baseline Risk Assessment was October 12. 1993. The first draft RI Baseline Risk Assessment for OUI was submitted on October 5. 1993. The final draft was scheduled to be submitted in Jannuary 1994.

- The submittal deadline for the OU4 RI Report/Baseline Risk Assessment was April 19, 1993. The ruport was submitted in draft form on April 19, 1993 and approved by OEPA on November 23, 1993. Approval by USEPA is expected in 1994.

- The submittal deadline for the OU/4 Feasibility Study Froposed Plan was September 10. 1993. The report was submitted on September 9, 1993. USEPA reviewed this document, and their approval on the revised plan is expected in 1994. 
- The submittal deadline for the OU5 Initial Screening of Alternatives was April 16. 1993. The final draft was submitted to USEPA on March 26, 1993.

Additionally, the OU3 RI/FS Work Plan Addendum was approved by USEPA on August 4. 1993.

In Decemher 1992. comments were received from USEPA on the Remedial Investigation (RI) repon for OU2. including requirements for additional field investigations. The site agreed that additional investigation was needed and requested an extension of the schedule imposed by the ACA for submittal of the RI report. This prompted a dispute with USEPA that was resolved through informal dispute resolution. As a result of this resolution. USEPA has accepted the revised schedule for submittal of the RI Report and for submittal of the Feasibility Study and Record of Decision (ROD). The revised schedule requires the submittal of the OU2 Feasibility Study/ Proposed Plan (FS/PP) on April 29, 1994. and the OU2 ROD on January 5, 1995. USEPA also agreed that, as an alternative to paying a large stipulated penalty. DOE will fund and implement a Supplemental Project in OU5 to provide additional treatment for uranium removal from Fernald site wastewater streams. The dispute resolution also accelerated the schedules for OUs 1, 2, 3, and 5.

\section{SARA}

The Superfund Amendments and Reauthorization Act of 1986 (SARA) was written to clarify and expand CERCLA ("Superfund") requirements. The SARA Title III, Section 312 report for 1993 was completed and submitted to OEPA. This report lists the amount and location of hazardous substances stored or used in amounts greater than the minimum reporting threshold.

The SARA Title III. Section 313 Toxic Chemical Release Inventory Report was submitted to OEPA and USEPA on July 1, 1993. This report is required for any toxic chemical that is manufactured. processed. or otherwise used at a facility in quantities greater than a minimum reporting threshold. A report was completed for methanol and sulfuric acid which were processed or otherwise used at the Fernald site. The Toxic Chemical Release Inventory Report lists routine and accidental releases, as well as information about the activities, uses, and waste for each reported toxic chemical. The report also included source reduction and recycling information as required by the Pollution Prevention Act of 1990.

For any offsite release exceeding the reportable quantity, SARA Title III. Section 304 requires immediate notifications to Local Emergency Planning Committees and State Emergency Response Commissions. All releases are evaluated to ensure that proper notitications are made in accordance with SARA. In addition to SARA. releases are also evaluated for notification under CERCLA Section 103, Resource Conservation and Recovery Act (RCRA), the Toxic Substances Control Act (TSCA), the Clean Air Act, the Clean Water Act, Ohio environmental laws and regulations, and the Ohio Fire Code. Department of Transportation regulations are also followed. Depending 
on the respective requirements, notifications may also be made to the National Response Center (NRC), and to the appropriate federal, state, and local regulatory entities.

Although not reported under SARA, three release notifications were issued to offsite agencies during 1993. First, on April 28. 1993, there was a release of approximately 30 gallons ( $113 \mathrm{~kg}$ or 250 pounds) of uranyl nitrate hexahydrate (UNH) solution to the sidewalk and gravel outside Plant $2 / 3$ in the former production area. This solution contained barium, chromium, and uranyl nitrate but not in concentrations resulting in a release above their respective reportable quantities. The material was classified as RCRA hazardous waste. This release was reportable under RCRA because it exceeded the 1 pound reportable quantity for release from a hazardous tank system. This was reported to the OEPA Regional Administrator. Also, the $\mathrm{pH}$ of this solution was less than 2.0. This $\mathrm{pH}$ and the quantity (greater than $45 \mathrm{~kg} / 10(0)$ pounds]) qualified as a reportable CERCLA release and was reported to the NRC. It was not a reportable SARA release because it did not leave the site.

On August 11, 1993, there was a spill of approximately 0.5 pint or $0.2 \mathrm{~kg}(0.46$ pound) of hydraulic fluid into a suspected wetland in the K-6.5 area. Site personnel determined that this release qualified as "immediately reportable" under the Clean Water Act, and it was reported to the NRC. Follow-up investigations revealed that the release had not actually occurred in a designated wetland and, therefore, would not have been reportable.

On December 22, 1993, approximately 6 liters ( 1.5 gallons) of antifreeze, containing $80 \%$ ethylene glycol, or approximately $5.2 \mathrm{~kg}$ ( 11 pounds), was released from the water line of a portable trailer into the gravel near Plant 7 in the production area. This currently qualifies as a reportable CERCLA release and was reported to the NRC. It was not SARA reportable because it did not leave the site.

\section{RCRA}

The Resource Conservation and Recovery Act regulates treatment, storage, and disposal of hazardous waste. OEPA has been authorized to enforce its hazardous waste regulations (which are derived from federal RCRA regulations).

Past operations and ongoing cleanup activities generate both hazardous wastes and mixed wastes (containing hazardous and radioactive components). As a management practice, some wastes are accumulated in quantities less than 55 gallons at the point of generation in locations known as satellite accumulation areas. The waste may remain in these areas until 55 gallons have been ar cumulated, at which time it must be moved to a permitted RCRA storage area.

Because there are a limited number of facilities in the United States that can treat or dispose of mixed waste, a final disposal site for all Fernald site mixed waste is not yet available. Although some waste was shipped to the K-25 incinerator in Oak 
Ridge for incineration in 1993, most of the mixed waste currently remains onsite. The Federal Facilities Compliance Act (FFCACt) of Octoher 1992 provides DOE with relief from enforcement under the Land Disposal Restriction storage prohibition until 1995, provided that the waste is stored in accordance with all other RCRA requirements. The site submitted an initial conceptual treatment plan to OEPA in October 1993 and is scheduled to submit a draft plan in August 1994.

In addition to being subject to state and federal regulation, RCRA waste is handled according to the 1988 Consent Decree hetween the State of Ohio and DOE. In 1990, negotiations between the State of Ohio. DOE, and the former operating contractor (Westinghouse Environmental Management Corporation (WEMCO)) resulted in the Proposed Amended Consent Decree (PACD). The PACD was signed by all parties in January 1993 and became known as the Stipulated Amended Consent Decree (SACD).

In accordance with the SACD and RCRA, the site completed or initiated several activities relating to mixed waste storage during 1993. These included submittal of the RCRA Annual Report, revision of the RCRA Part B Permit Application, additional RCRA training of personnel, and continued weekly inspections of the mixed waste storage areas. Two storage areas were also upgraded to include floor coatings and secondary containment for storage of liquids.

OEPA conducted a routine compliance evaluation inspection of the fernald site in June 1993. The physical inspection of the facility was conducted on June 16 and 17 and was continued on June 2.3 in order 10 review specific records. As a result of these inspections, the Fernald site received a Notice of Violation, which addressed storage of wastes restricted from land disposal for a period of time greater than allowed by law.

As required by the FFCA, on September 14, 1993, USEPA conducted a Comprehensive Monitoring Evaluation of the site's Alternative RCRA Groundwater Monitoring Program. A report of the evaluation is anticipated from USEPA in carly 1994.

In December 1993, OEPA issued notice of several deficiencies resulting from an inspection by OEPA of the uranyl nitrate solution tank system, but it did not initiate an enforcement action. A response will be submitted to OEPA in early 1994 addressing resolution of these findings. Additional information is provided under "Neutralization of UNH Inventories" on page 60).

\section{Clean Air Act}

In Ohio, authority to enforee requirements of the Clean Air Act has been delegaled by USEPA to OEPA, except for the enforement of the National Emission Standards for Hazardous Air Pollutants (NESHAP) for radionuclides and radon. Most 
Fernald site air emission sources are regulated by USEPA as radionuclide sources and by OEPA as particulate. chemical, or toxic emission sources.

The NESHAP standard for radionuclide air emissions from DOE facilities imposes a limit of 10 mrem per year on the effective dose equivalent (EDE) to the maximallyexposed individual as a result of all emissions (with the exception of radon) from the facility in a single year. This standard also imposes requirements for continuous monitoring of certain emission sources and periodic confirmatory measurements of smaller sources. All NESHAP monitoring points at the Fernald site are in compliance with the requirements.

Because the Fernald site is a former uranium processing plant, uranium is the radioactive particulate of most concern in monitoring airborne emissions. The

Figure 19: Total Kilograms of Uranium to Air, $1989-1993$

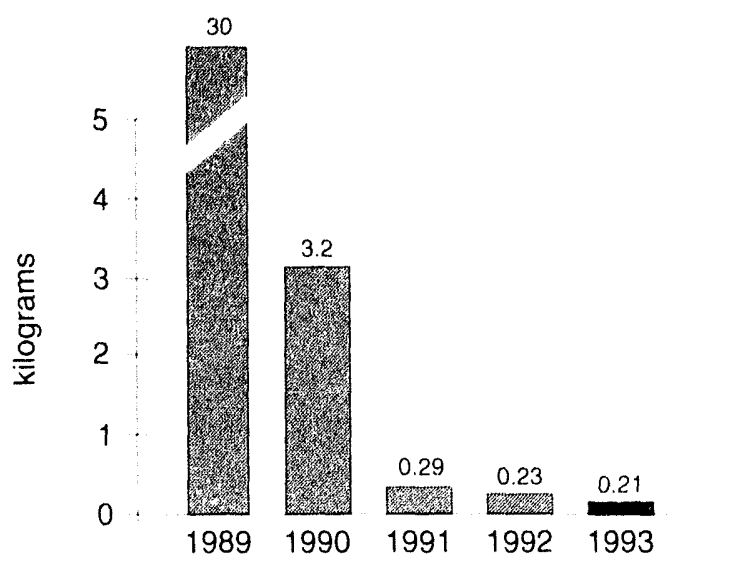

Fernald site estimated that airborne uranium emissions for 1993 totalled $0.21 \mathrm{~kg}(0.46$ pound). This is slightly lower than the $0.23 \mathrm{~kg}$ (0.51 pound) estimated in 1992 (see Figure 19). Airborne uranium emissions steadily dropped after processing operations were discontinued in 1989, and they have remained relatively constant since 1991.

In 1993, the State of Ohio regulation limiting sulfur dioxide $\left(\mathrm{SO}_{2}\right)$ emissions became effective which reduced the allowable $\mathrm{SO}_{2}$ emission level from the Fernald site's coal-fired burners (sole Clean Air Act-defined major source) from (0.91 $\mathrm{kg}\left(2.0\right.$ pounds) $\mathrm{SO}_{2} / 10^{\prime} \mathrm{btu}$ heat input to $0.60 \mathrm{~kg}$ ( 1.33 pounds) $\mathrm{SO}_{2} / 10^{6}$ btu heat input. The Fernald site began purchasing a low-sulfur coal in 1991 when the regulation was revised, and the site has been in compliance with the reduced limit since that time.

Under the Ohio Administrative Code, the Fernald site must obtain a Permit to Install (PTI) prior to the construction of an air pollutant source. The Fernald site is also required to obtain a Permit to Operate (PTO) for all operating air pollutant sources. Applications have been prepared for all required air permits. Due to the ongoing remedial activities (as opposed to production activities), the number of air permits will continue to diminish. 


\section{Clean Water Act}

Under the Clean Water Act, the Fernald site is governed by National Pollutant Discharge Elimination System (NPDES) regulations that require the control of discharges of nonradioactive pollutants to Ohio waters.

\section{NPDES Effluent Regulation}

The NPDES permit issued by the State of Ohio specifies discharge and sampling locations, sampling and reporting schedules, and discharge limitations. The permit was modified effective May 20, 1993, deleting two monitored outfalls and adding a sewage sludge monitoring location. Current monitoring locations are referenced in Figure 20. Other changes to the NPDES permit include eliminating certain pollutants, modifying monitoring frequencies and clarifying sampling techniques.

In 1993, the Fernald site was compliant with the discharge limits specified by the NPDES permit $99.73 \%$ of the time. Of the $4 .(20$ monitoring results, only 11 were not within the discharge limits specified by the permit. Of those 11 instances, three occurred at the site's discharge point (Manhole-175) and eight occurred at internal monitoring points. The Manhole- 175 occurrences involved $\mathrm{pH}$ and suspended solids. Occurrences at the internal monitoring points involved $\mathrm{pH}$ and chromium.

\section{NPDES Stormwater Regulation}

Issuance of a "Stormwater Permit Associated with Industrial Activity" is still pending OEPA review and action. The application for this permit was submitted for four stormwater discharges into Paddys Run in September 1992. These four monitoring locations are shown in Figure 20 as follows:

- STRM ())I - Collecting runoff from the cast and south;

- STRM 002 - Collecting runoff from the Inactive Flyash pile;

- STRM 003 - Collecting runoff from the western property perimeter. excluding the waste management facilities; and

- STRM 004-Collecting runoff from the northern property perimeter.

\section{Safe Drinking Water Act}

The Safe Drinking Water Act (SDWA) regulates generation and treatment of drinking water supplied to the public. The Fernald site drinking water system is regulated by OEPA as a non-transient, non-community public drinking water system.

During 1993, the site monitored and reported results for nitrate, nitrite. lead, copper, coliform bacteria, and 58 volatile organic compounds in addition to alkalinity, $\mathrm{pH}$, stability, phosphate, hardness, and chlorine residuals. All results met applicable standards. 


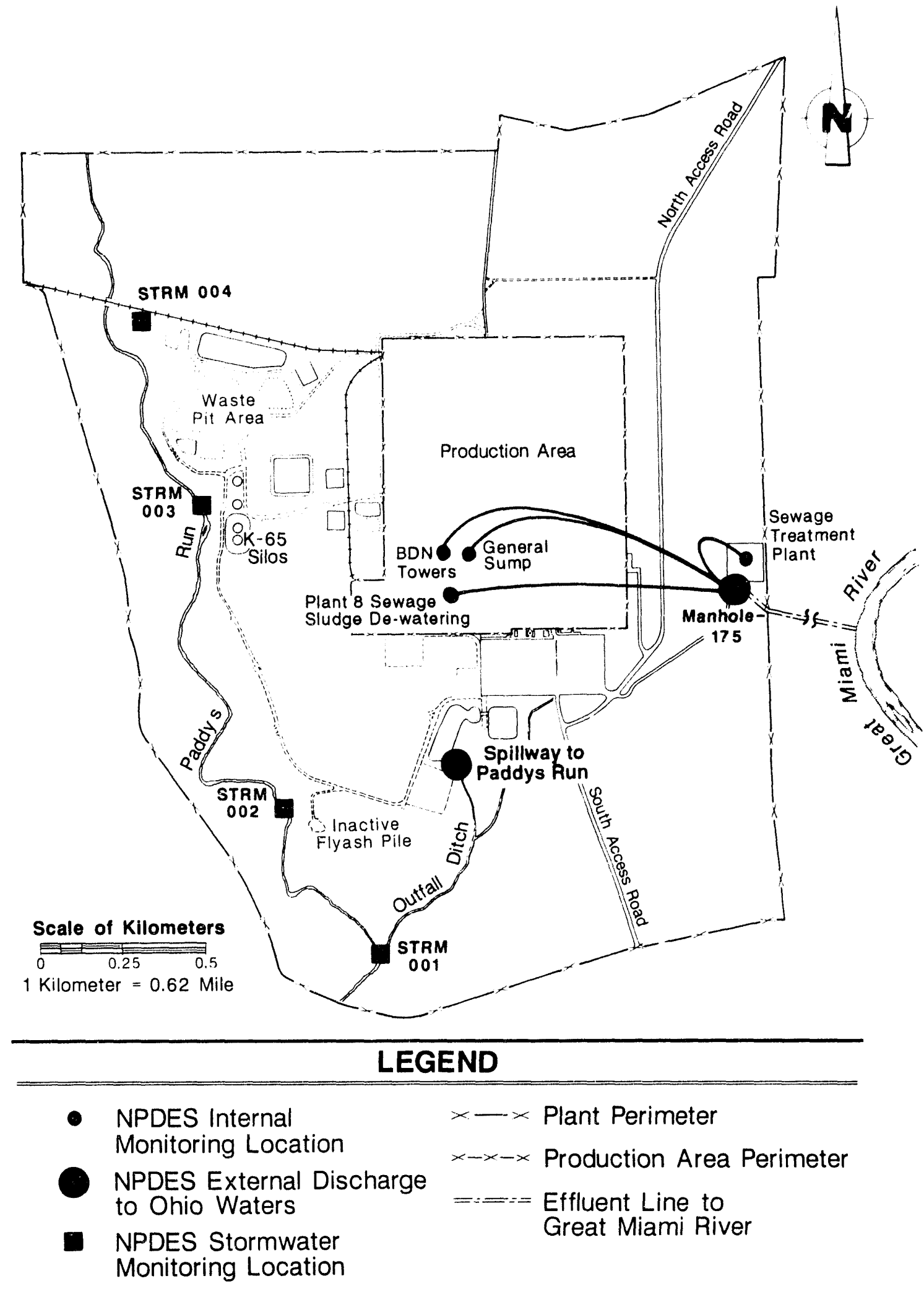




\section{Toxic Substances Control Act}

The Toxic Substances Control Act (TSCA) regulates the manufacturing, use, storage, and disposal of toxic materials. Under TSCA, USEPA regulates polychlorinated hiphenyl (PCBs) and PCB items at the Fernald site. The site ships non-radiologically contaminated PCBs and PCB items 10 commercial facilities for recycie or disposal on an ongoing basis. Radiologically contaminated PCBs and PCB items from past operations, maintenance activities, and remediation are stored onsite as disposal options are explored.

The site shipped four drums of PCB contaminated fluorescent light ballasts to a recycler in New York in October 1993. Additional shipments of both radiologically and non-radiologically contaminated PCBs and PCB items are scheduled for 1994 and 1995. The radiologically contaminated PCBs and PCB items are stored in Building 81 in compliance with TSCA requirements. Some PCBs and PCB items will remain onsite indefinitely due 10 the fack of treatment and disposal facilities for radiologically contaminated PCBs while on- and offsite disposal options are explored.

The site prepares the PCB Annual Document Log by July 1 of each year. The Annual Document Log includes signed manifests for PC B shipments, certificates of disposal, conversation reports, and PCB One-Year Exception Reports. The Annual Document Log must be maintained by the facility for a minimum of three years after the facility ceases using or storing PCBs or PCB items.

A Notice of Violation (NOV) was received on the Spill Control and Countermeasure (SPCC) Plan for PCB storage during 1993 as a result of a 1992 inspection. PCBs had been moved from Building 79 to Building 81 in 1992 without the necessary revision of the SPCC. A revised SPCC Plan was completed and provided to USEPA on a timely basis along with photographs of PCB storage facilities. USEPA accepted the submittal resolving the NOV during 1993.

\section{Ohio Solid Waste Act}

This 1988 act and its subsequent revisions regulate infectious, waste. In 1993, the Fernald site generated more than the $23 \mathrm{~kg}$ (5) pounds) per month limit of infectious waste and subsequently registered with OEPA at a large generator. All infectious wastes generated in the medical department are transported to a licensed treatment facility for incineration. Fernald site personnel conduct annual surveillances of the onsite medical department, the transporter, and the treatment facility to ensure that the waste is properly managed. 


\section{Federal Insecticide, Fungicide, and Rodenticide Act}

Under the Federal Insecticide, Fungicide, and Rodenticide Act (FIFRA), USEPA regulates the registration, storage, labeling, and use of insecticides, herbicides, and rodenticides. Fernald site pesticide applications have been performed by site personnel since September 1993. Prior to this time, pesticide applications were performed hy subcontractors. Herbicide applications are being performed by subcontractors. All pesticide and herbicide applications at the site are conducted according (o) Federal and state regulatory requirements. An annual FIFRA inspection by USEPA Region V in August 1993 identified no FIFRA violations. Pesticide applications are made in the administrative areal as well as the former production area. Herbicide applications are made in various locations for weed control within the former production area.

Construction began on a pesticide storage area located on the first floor of the Services Building in October 1993 and is scheduled to be completed in 1994. The primary function of this area will be for storage of chemicals and equipment that are now being used for pesticide application. This area will house a pesticide recycling station to support the Waste Minimization/Pollution Prevention program.

\section{National Environmental Policy Act}

The National Environmental Policy Act (NEPA) requires a formal evaluation of environmental, social, economic, and cultural impacts before any action, such as a construction project, is initiated by a Federal agency. DOE has published formal regulations specifically addressing the integration of NEPA with other regulatory requirements.

A total of 11 removal actions were approved as Categorical Exclusions (CXs) in 1993. In addition to these removal actions deemed as CXs, 23 other CXs were approved. Other NEPA related activities in 1993 included:

- Natural Recource Damage Assessment Trustees were noitied and a Strategy Paper was submitted to DOE.

- The OUI Feasibility Study/Proposed Plan-Draft Environmental Assessment was submitted to DOE,

- The OU3 Proposed Plan-Environmental Assessment was approved by USEPA,

- The OU4 Feasibility Study/Proposed Plan-Draft Environmental Impact Statement was submitted to DOE,

- A cultural resource survey was completed for the Horizontal Grout Barrier project and the report was submitted to DOE for submittal to the Ohio Historic Preservation Office, and

- Surveys for the state-threatened Sloan's crayfish and cave salamander were completed and the reports were submitted to DOE. 


\section{Endangered Species Act}

The Endangered Species Act requires the protection of any federal-listed threatened or endangered species found at the site as well ans any critical habitat that is essential for the species' existence. In addition. USEPA ecological guidelines direct CERCLA sites to identify any threatened species present on the property or in offsite areas affected by site activities. The haseline ecological survey conducted by Miami University (Oxford, Ohio) in 1986 and 1987, as well as RI/FS surveys in 1988 and consultation with the Ohio Department of Natural Resources, have established a list of federal-and state-listed threatened and endangered species that are or may be at the fernald site or have habitat at the site.

In 199.3, surveys to update the information on federal-and state-listed threatened and endangered species of the property were initiated. A study on the cave sallamander (Eurrece lucifitga), which is on Ohio's endangered species list, was conducted to update information from a 1988 study. Because of additional information gained on the life history of this species since the 1988 survey, areas along Paddys Run are no longer considered suitable habitat. However, preliminary data from the 1993 study show moderate habitat in one onsite limestone-lined well, marginal habitat in a northern ravine, and moderate habital in an offsite well adjacent to the southern boundary of the site. No salamanders were found in any of these areas.

A preliminary study for the Sloan's crayfish (Orcomectes slocmii) was initiated to update : species information found in the 1990 Miami University report. Qualitative sampling in Paddys Run in September 1993 found populations of this species onsite in the northern section of Paddys Run and offsite in the southern section. However, Paddys Run was dry in sections between these locitions. To verify that the populations are large enough to migrate upstream during regulat water flow, an updated survey is planned for the spring of 1994.

A Public Water Supply Project (discussed further in Chapter Six) involves the offsite installation of water pipelines along approximately $23 \mathrm{~km}$ ( 14 miles) of county and state roadways. Along the route of the pipeline are areas which may include threatened and endangered species or habitat. A threalened and endangered species survey for the project was completed in April 1993. While habitats for both the cave salamander and Sloan's craylish were found, none of the species were seen because of the season in which the study was conducted. Prior to completion of the project, a site ecologist will temporarily move any individuals of these species seen at that lime to an upstream location. 


\section{Executive Order 11920 , "Protection of Wetlands"}

This Executive Order is a directive requiring federal agencies to institute programs to identify and protect wetlands and is implemented by the site through 10 CFR 1(122. A wetlands delineation for the Fernald site was conducted in December 1992 and approved by the U.S. Army Corps of Engineers in August 1993. A total of 15 hectares (ha) (40) acres) of freshwater wetlands were delineated of the Fernald site. Delineated wetlands included 11 ha (27 acres) of palustrine forested wetlands, 3 ha (7 acres) of drainage ditches/swales, and 1 ha (2 acres) of isolated persistent emergent and scrub/shrub wetlands. In 1993, this delineation was utilized to prepare 10 CFR 1(22 wetland assessments for the OU 3 Interim Remedial Action (decontamination and dismantlement of all OU/3 facilities and structures), remedial actions associated with OU4 (silos 1-4 and associated properties), and the Vitrification Pilot Plant also for OU4.

\section{Executive Order 11988 , "Floodplain Management"}

This Executive Order instructs federal agencies to avoid construction in river floodplains and implements the order for DOE Regulation 10 CFR 1022. In 1993, HEC-2 modeling runs were conducted to determine the pool elevations for both the 1(0)- and 5()()-year flood for the portion of Paddys Run adjacent to the Fernald site. Modeling results predicted a maximum discharge rate of $15.8 \mathrm{~m}^{3} / \mathrm{sec}\left(11,150 \mathrm{ft}^{3} / \mathrm{sec}\right)$ at the confluence of the Paddys Run and the Great Miami River at a $1(0)$-year flood flow. The $1(1)$-year flood elevation ranged from 172 meters ( $567 \mathrm{ft}$ ) mean sea level at the site's northern boundary to 164 meters $(.542 \mathrm{ft}$ ) mean sea level at the southern edge of the site. Based upon the pool elevations predicted by the model, the $1(0)$-year and 500)-year flood flow would be retained within the banks of Paddys Run.

\section{National Historic Preservation Act}

In accordance with the Nattional Historic Preservation Act, activities at the Fernald site are required to take into account the impact on any cultural resources. Consultation and coordination with federal and state preservation agencies are required when there may he an impact to cultural resources.

Consultation with the State Historic Preservation Officer had established that certain areas would not require a cultural resources survey due to radiological or chemical contamination concerns. However, a survey and consultation for land disturbance activities outside these areas and at offsite locations are required. To address such activities, a Cultural Resource Management Plan was drafted and is currently being revised for the site.

The South Groundwatter Contamination Plume Removal Action required an archeological survey and consultation. Archeological surveys were conducted to verify the South Plume projects will not adversely affect cultural resources. The reports identified several cultural resources within the area. Through consultation with the State Historic Preservation Officer, no adverse affects were found within the project area. 
The Public Water Supply Project involves the installation of water pipelines along approximately $23 \mathrm{~km}$ ( 14 miles) of state and county roadways in Hamilton and Butler counties. An archeological survey for this project was conducted and revealed a number of historic and prehistoric artifacts. Through consultation with the State Historic Preservation Officer, it was determined that artifacts found at the proposed reservoir site were not significant and the site would not be eligible for the Nattional Register. However, consultation on other portions of the Public Water Supply is currently ongoing. with expected determinations to be made available in early 1994.

A cultural resources survey was required for the proposed site of the Horizontal Grout Barricr Demonstration Project, a technology demonstration being conducted by the site. No adverse impacts were found on cullural resources within the area surveyed.

\section{Current Accomplishments and Issues}

This section presents significant compliance-related accomplishments and issues for 1993.

\section{CERCLA}

In the course of a RI/FS effort, conditions occasionally call for a necessary action to abate an immediate threat to health and the environment, including actions necessary to monitor, assess, or evaluate the threat. These actions, called removal actions, are coordinated with USEPA and OEPA.

\section{Completed Removal Actions}

By 1993, the Fernald site had identified 30 removal actions. Ten of these had been completed prior to this reporting period. The following six removal actions were completed, in part or in whole, in 1993.

Scrap Metal Piles - The onsite portion of this removal action was completed in October 1993 when approximately 2,20) tons of recoverable low-level radioactive waste scrap metal were successfully containerized. This action eliminated potential air pollutant emission sources and risks to the Great Miami River by surface water runoff. The containerized material included approximately $1,3(0)$ tons of scrap copper and other small metal piles. All non-ferrous metal, a total of 105 tons, has been shipped to Quadrex. Additionally, the site completed the shipping of 2,278 tons of ferrous metal to SEG. Both Quadrex and SEG are commercial Treatment, Storage, and Disposal Facilities (TSDF), located in Oak Ridge, Tennessee. Through December 30, 1993, approximately 2,00() tons of ferrous metal had been melted for restricted reuse. Metal melting at of fsite facilities is expected to be completed in March 1994. Also, processing for unrestricted reuse should be completed in January 1994. 
Collece Uncomtrolled Production Area Rumoff (Northecest) - This removal action was completed in August 1993. The objective of this removal action was to collect uncontrolled process area runoff. This removal action involved the redirection of subdrainage areas and the collection of run-off from the perimeter of the former process areal to the Stormwater Retention Basin, therehy significantly reducing the release of uranium and other contaminants 10 Paddlys Run. Additionally, mitigattion of the flow of contaminants from surfice watter to the underlying aquifer will he achicved as a result of these activities.

Waste Pit Area Comteinment lmprosement - The purpose of this removal action was to mitigate sources of potential airborne dust emissions and contaminated surface water runoff from the Waste Pit Area. The removal action, completed in June 1993. involved both the revegetation (seeding) of the pit area for erosion control and regrading of some existing stormwater ditches in the pit area to promote positive drainatge.

Pilot Plant Sump) - The stainless steel sump, located southeast of the Pilot Plant, was intended to remove and collect liquids from the floors of the Pilot Plant. Analytical sump sample results revealed high concentrations of lead, copper, chromium, nickel. thorium, and volatile organic compounds. In order to mitigate this source of potential environmental releatses, both the sump and the contaminated liquids and solids contained in the sump were removed. The project was completed in October 1993.

Nitric Acid Tank Car and Area - This stainless steel tank car operated from 1952 until 1989 as a nitric acid storage vessel for production purposes at the Fernald site. The tank car and surrounding area are designated as a Hazardous Waste Management Unit in the site's Part A and Part B permit applications. The removal action involved the removal of acid from the tank car prior to its decontamination and disposal. In Oetober 1993, the contents of the rail car were transferred to the Tank F1-24 of the Nitric Acid Recovery System of the Wastewater Treatment System for eventual treatment. Samples taken from the tank base and surrounding area, after completion of this removal action, indicated chromium to be below regulattory concern. The final repory was submitted to DOE on October 18, 1993, and was transmitted to both Ohio and USEPA on November 2, 1993.

Stabilization of Paddys Run Bank Near the Inactive Flyash Pile - This "time critical" removal action was performed in Iwo phases. Phase 1, an interim action completed in May 1993, involved the placement of a 67-meter (220-foot) long rock berm along the bank of Paddys Run in the immediate proximity of the Hyash pile. This activity mitigated the threat of erosion-induced slope failure that could potentially result in the discharge of llyash to the creek. The rock herm enhancement project. Phase 2. wats alcomplished in September 1993 by the addition of aggregate material to the rock berm. Phase 2 was determined to be necessary to control additional erosion not originally anticipated by Phase I planning activities. 


\section{Ongoing Removal Actions}

The following eleven removal actions are underway to alleviate immediate threats (o) the environment:

- Contaminated Water Under Fernald Site Buildings.

- South Groundwater Contamination Plume,

- Plant I Pad Continuing Release.

- Removal of Waste lnventories.

- Sifle Shutdown.

- Plant 1 Ore Silos,

- Contaminated Soils Adjacent to Sewage Treatment Plant Incinerator.

- Scrap Metal Pile (offsite activities).

- Plant 7 Dismantling.

- Stabilization of Uranyl Nitrate Inventories, and

- Ashestos Removals.

The remaining removal actions, listed helow, are in the planning or implementation process:

- Improved Storage of Soil and Debris,

- Management of Contaminated Structures, and

- Contamination at the Fire Training Facility.

\section{Other CERCLA Accomplishments and Issues}

Advanced Wastewater Treatment (AWWT) Facility - Construction on the advance: wastewater treatment system began on May 11, 1993. progressed throughout 1993. and is on-going. The purpose of the AWWT is to provide uranium removal for contaminated wastewater, stormwater. and a portion of the South Plume.

Comprchensive Groundwater Monitoring Evaluation - On September 14 and 15, 1993. USEPA Region V. joined by OEPA, conducted a RCRA Comprehensive Groundwater Monitoring Evaluation of the site's RCRA groundwater monitoring system, known as the routine system. The evaluation was conducted per the September 10, 1993, Director's Final Findings and Orders (DFOs) for groundwater monitoring. The RCRA Comprehensive Groundwater Monitoring Evaluation involved determining the condition of the monitor wells and the groundwater sampling procedures and documentation. No violations of Ohio's hazardous waste regulations pertaining to groundwater monitoring were noted. However, three deficiencies for specilic monitor wells were identified:

- The concrete pad at Well 3106 appeared to be loose and must be replaced;

- The concrete pad at Well 3431 appeared to be loose and must be replaced; and

- The teflon hose attached to the dedicated pump on Well 307() was crimped and damaged and must be replaced. 
USEPA also recommended that each routine system monitor well have bumper guards placed around the wellhead and dedicalled sampling pumps installed. The site is currently addressing the above deficiencies and recommendations.

Neutralization of UNH Ime'moriess - The stabilization of UNH inventories will remk ve and prepare approximately 230,()K() gallons of acidic UNH for safe storage that is currently stored in 21 tanks in and around Plant 2/3. This activity was previously part of the Safe Shutdown removal action hut is being performed as a separate, expedited response. In April 1993, UNH from a storage tank was inadvertently pumped to wastewater tanks resulting in the spillage of approximately 30 gallons of material. The project was halted pending implement:tion of the recommendations resulting from the DOE Class B investigation. A December 1993 OEPA inspection resulted in a finding of deficiencies for three RCRA tanks. Two deficiencies were corrected by pumping liquid from secondary containment within 24 hours of the inspection. Repairs to minor pipe leaks are in progress. A dedicated project team has been assembled to develop a new tank configuration designed for safe and efficient neutralization and disposition of the stored materials.

Plam I Ore Silos - The Plant I Pad ore silo removal action will dismantle 14 ore silos and associated support structures. This will eliminate the potential threat of additional releases and the safety hazard due to structural deterioration of the silos and associated support structures. On December 17, 1993. FERMCO issued a contract termination letter to the Size Reduction Operation subcontractor for failure to perform its contractual obligations. A revised construction operation schedule has been developed and all construction/distmantling activities are tentatively scheduled for completion in September 1994. It is anticipated that there should be no delay in the Consent Agreement commitment date of December 19, 1994, for this Removal Action.

Plant 7 Distrantling - Plant 7 decontamination and dismantling (D\&D) operations will mitigate potential releases and support the DOE Integrated Technology Demonstration Program. The Plant 7 D\&D operations will also serve as a pilot program for the future remediation of the :ite. Phase I activities, primarily involving the relocittion of stored drum material and the removal of interior asbestos insulation, were completed in October 1993. Gross decontamination activities of the interior building components were essentially finished in November 1993. Subcontractor dismantling operations are on-going.

Director's Final Findings and Order - The DFO, signed September 10, 1993, describes an alternate groundwater monitoring system with a routine monitoring program that allows hazardous waste monitoring requirements to be fulfilled by the CERCLA process already underway. This resolves the integration process concerning the state regulations and the CERCLA requirements at the Fernald site. 


\section{RCRA}

The Stipulated Amended Consent Decree requires that the site identify all Hazardous Waste Management Units (HWMUs) at the facility. As a result, burners, incinerators, furnaces, stills, process equipment, tank units, dust collectors, and other potential waste containment units were evaluated to determine if these units were HWMUs or Solid Waste Management Units (SWMUs). Beginning in 1993, the site reviewed the evaluation process, regulatory basis, and technical assumptions used to determine whether the designation of these units as HWMUs was justified. OEPA approval has been sought to change the designation for the HWMUs which should be designated as SWMUs. In 1993, concurrence was obtained from OEPA to change the determination of five of the 53 HWMUs to SWMUs. This review of the evaluation process will continue in 1994.

\section{Thorium Management}

A Thorium Management Strategy and schedule of accomplishments were developed as part of the SACD to provide a plan to complete RCRA determinations of thoriam materials and to improve the storage of thorium materiais at the Fernald site. The Thorium Management Strategy was initiated as part of the SACD and is based on three primary objectives:

- To maintain environmentally stable interim storage of the thorium inventory while minimizing personnel radiation exposure,

- To implement required further actions to complete RCRA evaluations of the thorium materials, and

- To implement long-term storage and disposal alternatives.

In 1993, three drums of thorium materials were shipped to the Nevada Test Site. Also in 1993, the site completed the overpacking of 6,100 drums of thorium materials and expects to have approval to ship those materials to Nevada in 1994.

\section{Land Disposal Restriction Waste}

The Fernald site stores mixed waste subject to the RCRA Land Disposal Restrictions (LDR). These restrictions currently prohibit the storage of certain hazardous waste streams unless an extension is approved by USEPA or the appropriate state regulatory agency. Due to the lack of available treatment and disposal facilities for mixed wastes. DOE facilities, including the Fernald site, are continuing to store this mixed waste. The FFCA of October 1992 provides DOE with relief from enforcement under the LDR storage prohibition until October 1995, provided that the waste is stored in accordance with all other RCRA requirements. This time period may be extended further if DOE submits and obtains approval of a plan for providing the required treatment for LDR mixed waste. Such a plan must be approved before October 1995. The Fernald site submitted an initial conceptual plan in October 1993 and is scheduled to submit a draft plan to OEPA in August 1994. 


\section{RCRA Closures}

During 1993, activities were underway to plan and implement the closure of Fernald site HWMUs. Many of these activities consisted of proposing, obtaining OEPA approval, and implementing RCRA closures in conjunction with the CERCLA response actions being undertaken under the Amended Consent Agreement with USEPA. RCRA closure activities during calendar year 1993 are charted on next page.

\section{Environment, Safety, and Health Assessments}

The concept of Environment, Safety, and Health (ES\&H) Assessments was developed to evaluate compliance of all DOE facilities with regulatory requirements. To determine the actions taken in response to previous ES\&H Assessment findings, the Secretary of Energy ordeied that small, focused Progress Assessments be performed. The ES\&H Progress Assessment at the Fernald site, conducted from October 15 through October 25, 1991, was the pilot progress assessment for this program. Key findings were cited representing potential compliance issues related to federal and state regulations or DOE Orders.

The latest draft Action Plan in response to the Progress Assessment was submitted to DOE Headquarters for review and approval in December 1993. The plan contains 103 response actions. FERMCO has completed all actions for which it was responsible. Pending DOE approval, five actions, for which DOE is responsible, are scheduled to be completed during 1994.

An Environment, Safety, and Health and Quality Assurance functional appraisal of the Fernald site was conducted in November 1992. The final audit report identified 72 deficiencies related to federal and state regulatory requirements. Deficiencies were categorized into one of the three functional categories of FERMCO's Quality Assurance Program Description as follows: 17 deficiencies in Program, 41 deficiencies in Performance, and 14 deficiencies in Assessment.

An Environmental Management Assessment of the Fernald site was conducted by DOE Headquarters in March 1993. The assessment identified 20 findings. Fourteen of these findings were in the management systems areas, and six were in the technical areas of radiation and quality assurance. A draft action plan in response to the 20 deficiencies identified was issued in June 1993. FERMCO has not received comments on the action plan.

DOE-Headquarters, Office of Nuclear Safety. performed a Radiological Evaluation in May 1993. The evaluation identified 32 deficiencies that were consolidated into seven external corrective action reports. Deficiencies were categorized into one of the three functional categories of FERMCO's Quality Assurance Program Description as follows: eight deficiencies in Program, 19 deficiencies in Performance, and five 
HWMU No. HWMU Description

\begin{tabular}{|c|c|c|}
\hline 1 & Fire Training Facility & RAWP'/CPID ${ }^{2}$ submitted August 6, 1993 \\
\hline 2 & Parts Cleaner in Welding Shop & $\begin{array}{l}\text { Received OEPA approval to withdraw } \\
\text { November } 1,1993\end{array}$ \\
\hline 4 & $\begin{array}{l}\text { Drum Storage Area Near Loading I } \\
\text { Dock llab }\end{array}$ & CPID submitted to OEPA April 4, 1993 \\
\hline 6 & Drummed HF Storage Inside Plant 4 & $\begin{array}{l}\text { Responded to NOD February } 13,1993 \\
\text { closure certification due to OEPA in } 1994\end{array}$ \\
\hline 7 & $\begin{array}{l}\text { Drummed HF Residue Storage NW } \\
\text { of Plant } 4\end{array}$ & CPID to be replaced with administrative closure \\
\hline 9 & Nitric Acid Rail Car and Area & $\begin{array}{l}\text { RAWP/CPID approved March 8, 1993; RAWWP/ } \\
\text { CPID field work completed October } 1993\end{array}$ \\
\hline 10 & $\begin{array}{l}\text { Nitric Acid Recovery System } \\
\text { Components }\end{array}$ & Submitted CPID June 30,1993 ; in OEPA review \\
\hline 23 & Well Drilling Storage Area & $\begin{array}{l}\text { Received OEPA approval to withdraw } \\
\text { November } 1,1993\end{array}$ \\
\hline 24 & Equipment Storage Area & $\begin{array}{l}\text { Received OEPA approval to withdraw } \\
\text { November 1, } 1993\end{array}$ \\
\hline 26 & Detrex Still & $\begin{array}{l}\text { Submitted CPID November 5, 1993; } \\
\text { in OEPA review }\end{array}$ \\
\hline $31 / 32$ & Bulk Storage Tanks T-5 and T-6 & $\begin{array}{l}\text { Amendment to CPID submitted November } 18 \text {, } \\
\text { 1993; in OEPA review }\end{array}$ \\
\hline 36 & Storage Pad North of Plant 6 & $\begin{array}{l}\text { Amendment to CPID submitted December } 30 \text {, } \\
\text { 1993; in OEPA review }\end{array}$ \\
\hline 39 & Clearwell & $\begin{array}{l}\text { Received OEPA approval to withdraw } \\
\text { June } 7,1993\end{array}$ \\
\hline 43 & Lime Sludge Ponds & $\begin{array}{l}\text { Received OEPA approval to withdraw } \\
\text { June } 7,1993\end{array}$ \\
\hline 44 & Coal Pile Runoff Basin & $\begin{array}{l}\text { Received OEPA approval to withdraw } \\
\text { June } 7,1993\end{array}$ \\
\hline 45 & Underground Storage Tank No. 5 & $\begin{array}{l}\text { Received OEPA approval to withdraw } \\
\text { November } 1,1993\end{array}$ \\
\hline $46-50$ & UNH Tanks & $\begin{array}{l}\text { Undergoing closure under Removal Actions } 12 \\
\text { and 20; CPID submitted June 22, } 1993\end{array}$ \\
\hline 52 & North \& South Spent Solvent Tanks & $\begin{array}{l}\text { CPID submitted December 30, 1993; } \\
\text { in OEPA review }\end{array}$ \\
\hline
\end{tabular}

\footnotetext{
${ }^{1}$ Removal Action Work Plan

${ }^{2}$ Closure Plan Information and Data

${ }^{3}$ Notice of Deficiency
}

\section{Status Of Closure/Submittal}

Received OEPA approval to withdraw November 1, 1993 
deficiencies in Assessment. As a result of the 32 deficiencies identified, a Corrective Action plan was submitted to DOE-Fernald Field Office. All deficiencies were corrected prior to plan submittal.

A Technical Assist Visit was conducted by DOE-Headquarters in August 1993 of the site's Emergency Preparedness Plan (as required by DOE Orders). The Technical Assist Visit, a new program conducted at only three DOE facilities in 1993, was developed to provide a mechanism through which the DOE-Headquarters inspectors can provide program recommendations and advice in a non-enforcement capacity. No verbal findings were received from DOE-Headquarters inspectors at the time of the visit. The final Technical Assist Visit report has not been received by the Fernald site at this time.

The remainder of this report presents the results from the Environmental Monitoring Program at the Fernald site, beginning with a discussion on the Air Pathway. The estimated radiation doses for 1993 are also presented, as well as the Radon Monitoring Program results. 


\section{4 \\ Air Pathway Monitoring}




\section{Air Pathway Monitoring}

This chapter describes the air pathway and its components that may become contaminated as a result of airborne emissions from the site. Although it is not a true component of the air pathway, a discussion of the direct radiation monitoring program and results are included here for convenience.

As discussed in Chapter One, the public may be exposed to radiation from the site through the air pathway. This includes emissions from specific point sources (such as plant stacks), as well as dust from large, open areas, such as the waste pit area. When production operations were suspended in mid-1989, the major point source emissions from the site were eliminated. Since then,

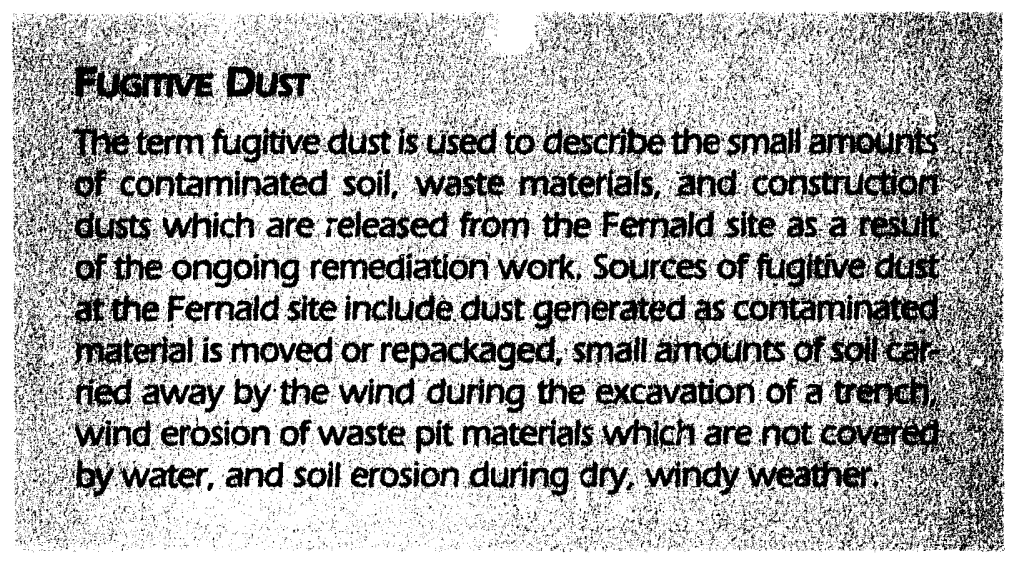
the principal sources of airborne uranium emissions have been the cooling tower mists, which have low levels of uranium contamination, and fugitive dust from locations where environmental cleanup activities are undenway.

Air pathway monitoring focuses on the airborne pollutants that may be carried from the Fernald site as a particulate or gas and how these pollutants are distributed in the environment. Stack and building vent emissions are obvious sources of pollutants, but dust from construction and remediation activities, waste handling, and wind erosion are also important potential sources. The form and chemical makeup of pollutants influence how they are dispersed in the environment as well as how they may deliver radiation doses. For example, fine particles and gases remain suspended, while larger, heavier particles tend to settle and deposit on grass or soil. Chemical properties determine whether the pollutant will dissolve in water, be absorbed by plants and animals, or settle in sediments and soils. 


\section{Results in Erief: 1993 Arr Pathway}

Air - Data collected from fenceline air monitoring stations show that average concentrations of uranium were all less than $1 \%$ of the DOE standard. Airborne uranium emissions for 1993 were estimated to be $0.21 \mathrm{~kg}$ (0.46 pound).

Soil - Some onsite and nearby offsite soil samples continue to indicate elevated uranium concentrations due to deposition of airborne particles from past operations. One offsite sampling location, in the predominant wind direction northeast of the site, had a total uranium concentration of $5.3 \mathrm{pCi} / \mathrm{g}$, which is above the background level of $2.8 \mathrm{pCi} / \mathrm{g}$ for the Fernald area. ${ }^{23}$

Grass - The 1993 results indicate that uranium concentrations are higher at fenceline and onsite locations than at offsite locations. The onsite grass concentrations are better correlated to local airborne uranium concentrations than soil concentrations, which suggests that deposition is the source of the higher concentrations

Produce - Uranium concentrations in produce were consistent with previous years' data. Laboratory analyses did not detect any significant differences in uranium concentrations between produce grown near the plant and produce grown at locations distant from the plant.

Milk - In general, uranium concentrations from the local dairy are comparable to those from a background dairy in Indiana. The data demonstrate that milk from the local dairy is not affected by site emissions.

Direct Radiation - Measurements of direct radiation indicate that levels increase with proximity to the K-65 silos. These measurements are consistent with the fact that the silos contain radium and radon gas which contribute to the direct radiasion in the vicinity.

Boiler Plant - All emissions were well below permit limits. 


\section{Monitoring for Radioactive Pollutants}

During 1993, Fernald site personnel continued to monitor adioactive materials in the air pathway by sampling air, soil, grass, produce, and milk. This monitoring enables scientists to evaluate the effects of the cleanup efforts at the site, as well as fulfill the site's obligations toward ongoing environmental surveillance and dose estimating.

\section{Air Sampling for Radioactive Particulates}

The first step in monitoring the air pathway is measuring the emission rate of the pollutants at the point of release after they have gone through treatments and filtering. This is done by means of stack sampling, and it provides preliminary information on how much pollutant is released and how it will behave in the environment. The second step in air pathway monitoring involves measuring the polluted concentration in ambient air onsite and at the site boundary. Since only a few stacks and vents continue to emit pollutants at the site, airborne emissions from monitored stacks are substantially lower than during the years of production. However, monitoring of overall site emissions (stack and fugitive emissions) continues through the use of air monitoring stations (AMS) located onsite, near the site fenceline, and at several locations in nearby communities.

Airborne pollutants are subject to existing weather conditions; thus wind speed and direction, rainfall, and temperature play a role in predicting how pollutants are distributed in the environment. Weather data, particularly wind speed and direction, provide input for selecting locations for the collection of environmental samples and locating monitoring stations.

During 1993, the site operated 20) air monitoring stations 24 hours a day, seven days a week as part of the Air Monitoring Program. Scientists selected the locations for the AMSs, as shown in Figure 21, for several reasons:

- AMS 1 through 7 provide data at the fenceline because this is where the public has closest access to the site and guidelines for offsite exposure aply. In order to comply with DOE and EPA monitoring criteria, AMS I was moved to a location closer to the former production area in mid- 1993. The new location was designated AMS $1 \mathrm{~A}$ and is no longer on the site boundary;

- AMS 8 and 9 are in the prevailing wind direction at the site. They were added in 1986 to the northeast sector of the site based on a computer model that predicted where the highest ground-level concentrations of airborne uranium from plant operations would be found;

- AMS 10 through 14 are located at schools and industries near the site and provide additional monitoring of emissions at these points;

- AMS 15 and 16 were installed in 1989 to obtain additional background data AivS 15 is located near the University of Cincinnati, in Cincinnati, Ohio; AMS 16 is located in Miamitown. Ohio; and 


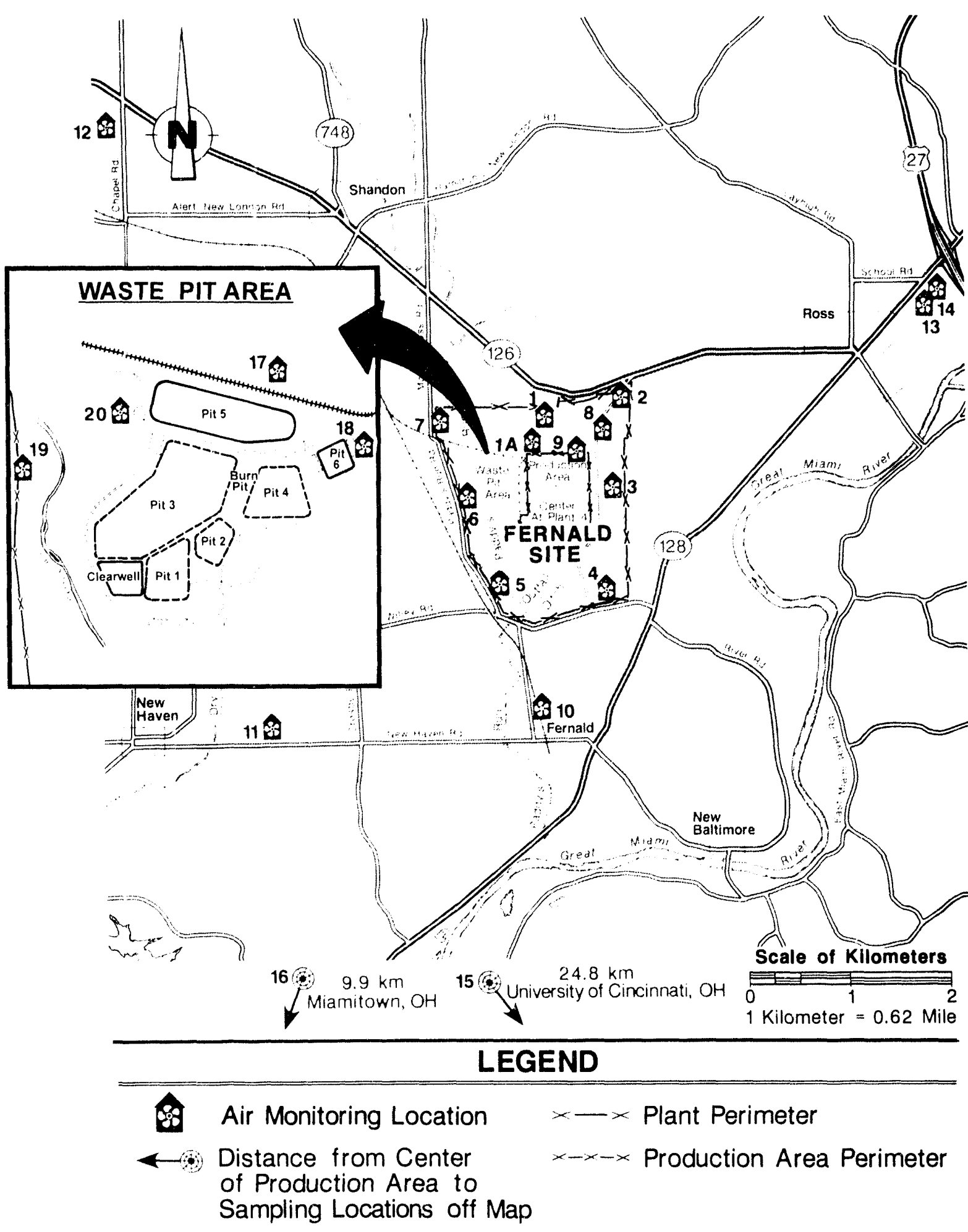


- AMS 17 through 20 were installed in 1992 to provide increased monitoring of waste pit emissions. These monitors will provide valuable information on any pit emissions which occur during waste pit remediation.

At each AMS, air is drawn through a $20 \mathrm{~cm}$ by $25 \mathrm{~cm}$ ( 8 inches by 10 inches) filter at a rate of about $1.3 \mathrm{~m}^{3}$ per minute (about $45 \mathrm{ft}^{3}$ per minute). Technicians account for any changes in flow rate over the sampling period by inspecting charts that continuously record flow data.

Environmental monitoring personnel collect the filters from the AMSs for analysis at weekly intervals. At the laboratory, technicians store the filters for at least three days following collection to allow naturally occurring, short-lived rudionuclides (such as radon daughters) to decay. It is important to note that this holding period does not affect the amount of uranium on the filters. After the holding period, laboratory technicians heat the filters to $550^{\circ} \mathrm{C}\left(1,022^{\circ} \mathrm{F}\right)$ to remove organic matter. Finally, they dissolve these filters in acid and analyze the resulting solutions for uranium. A portion of each of these solutions is retained each week to prepare an annual composite, which is then analyzed for trace concentrations of radionuclides such as isotopes of radium, neptunium, plutonium, and thorium.

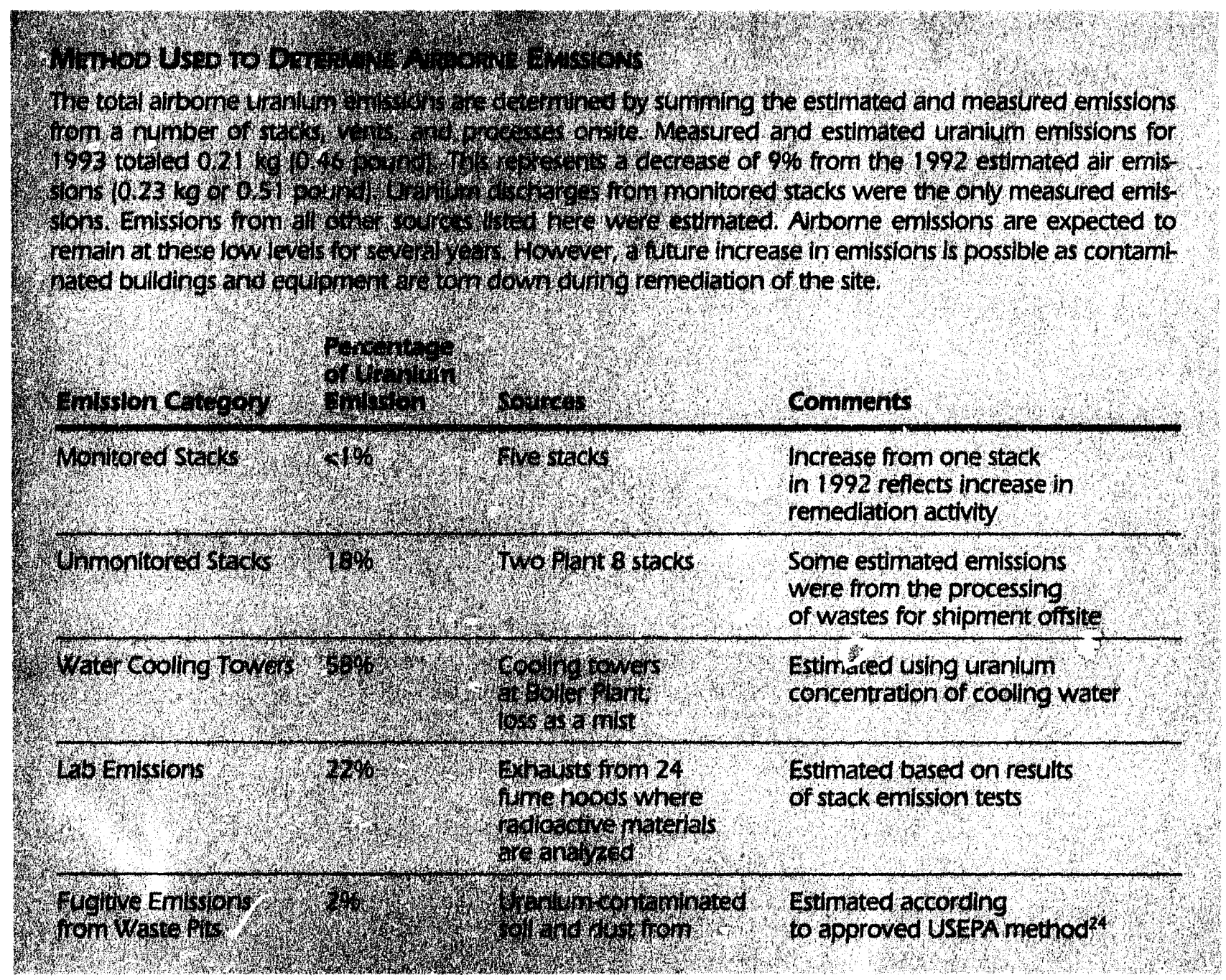


2000

1500

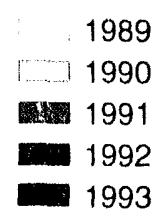

1000

500

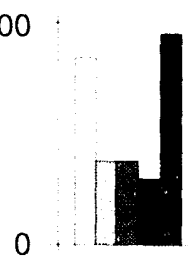

1

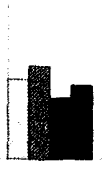

2

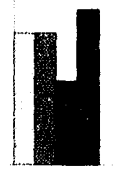

3

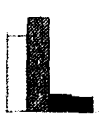

4

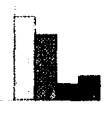

5

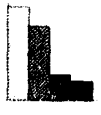

6 Fenceline AMS

DOE Order 540().5, "Radiation Protection of the Public and the Enviromment," establishes guidelines for concentrations of radionuclides in air emissions. These guidelines. referred to as Derived Concentration Guidelines (DCGs), are concentrations of radionuclides that, under conditions of continuous exposure for one vear by one exposure mode. would result in a dose of 100 mrem. The intent of the DCGs is to provide reference values that enable site personnel to review effluent data and determine if there is a potential to exceed the limits on dose to members of the public.

The average concentrations of uranium at the seven fenceline AMSs (AMS I through 7) were all less than 1\% of the DOE guideline. Table 3 on page A-4 lists 1993 data for uranium concentrations. Figure 22 compares uranium concentrations at the air monitoring stations for 1989 through 1993. The higher concentrations measured at AMS 9. located within the former production area, are in part attributed to the emissions from contaminated scrap metal pile that was located in the northeast section of the production area. The contaminated scrap metal was packaged and removed from the site during 1993. 
The data on the concentrations of trace radionuclides in 199.3 are presented in Table 4 on pages A-5 through A-7. The results indicate that concentrations of trace radionuclides at the onsite and fenceline locations are well below DOE guidelines. Concentrations of thorium-232, measured at the AMSs, for 1989 through 1993 are presented in Figure 23. Thorium-2.32 is stored in quantity at several locations onsite and is considered a potential environmental contaminant.

Figure 23: Average Thorium-232 Concentrations in Air, $1989-1993$

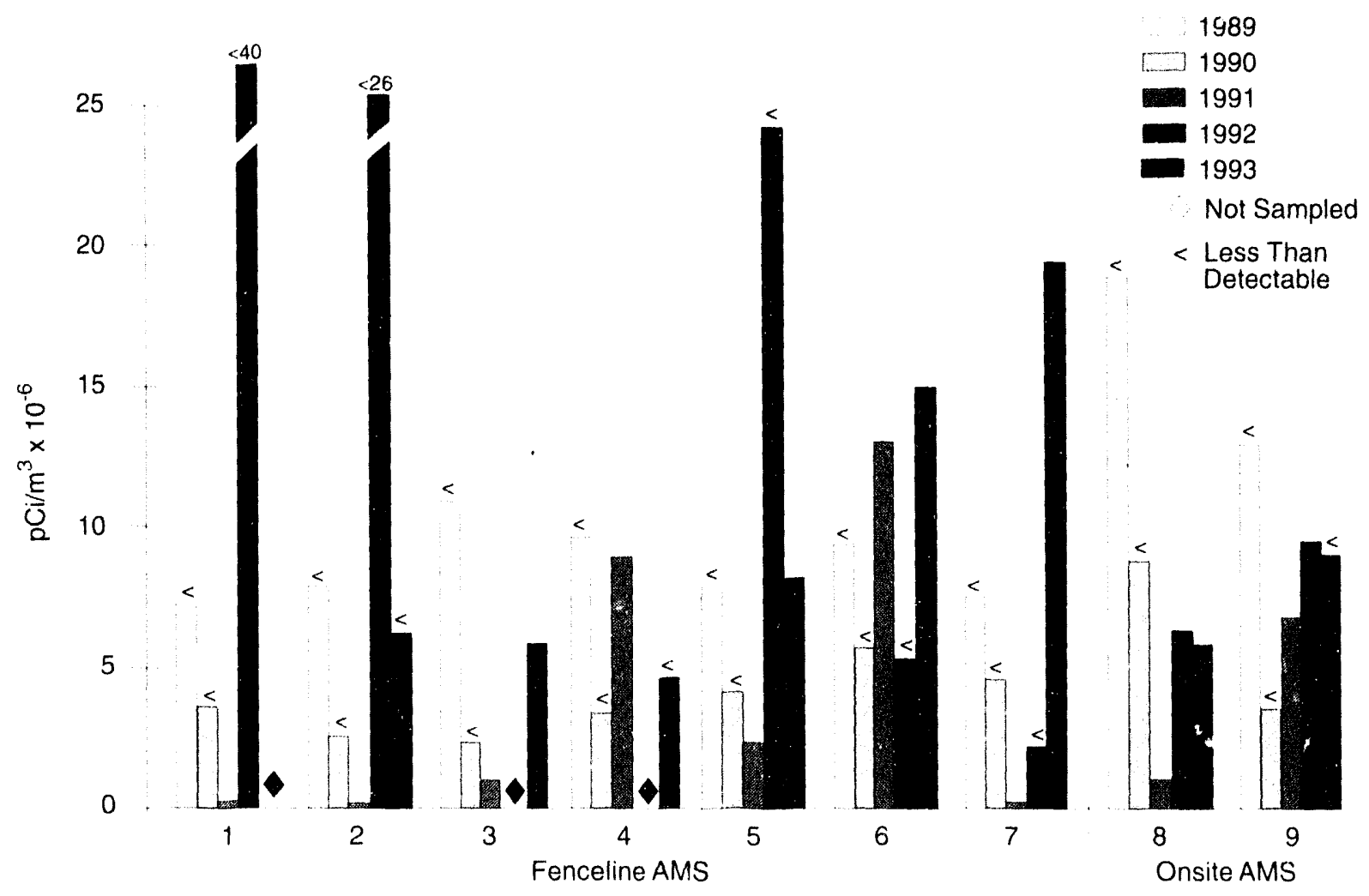

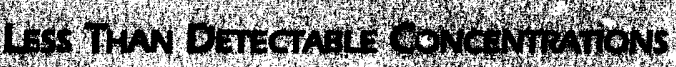

The less than symbol 14 is used here when the concentration of thorium-232 in ait could not be refiably measured in the sample which was analyzed. That is, the amount of thorium-232, if present St all in the sample, was below the hinimum measurable concentration. Thus, a concentration of $440 \mathrm{pCl} / \mathrm{m}^{3} \times 10^{-6}$ means that the thonum concentration was less than $40 \mathrm{pCl} / \mathrm{m}^{3} \times 10^{-6} \mathrm{but}$ actu ally could have been anywhere from 0.00 to $39.9 \mathrm{pe} / \mathrm{m}^{3} \times 10^{6}$. While it is dificult to accurately compare these data from year to year that do not have rellable measurements, it is important to keep in mind that even the highest concentrations shown here are well below the DOE limit. The OCG for thorium 232 in air is $7,000 \mathrm{pdim} \mathrm{m}^{3} \times 10^{\circ}$ 


\section{Comparison of Measured and Estimated Emissions}

Scientists compared average air concentrations of uranium measured at the seven fenceline air monitoring locations to the predicted concentrations at the stations based on the cmissions estimate of $(0.21 \mathrm{~kg}$ ( $(0.46$ pound) of uranium. The comparison provides a means to evaluate the accuracy of the estimated emissions.

Results of the comparison are provided in Table 5 on page A-8. The results indicate that the measured concentrations are higher than the predicted concentrations. This finding suggests that the estimated emissions are higher than $0.21 \mathrm{~kg}(0.46$ pound). Fugitive dust from various remediation work is a possible cause of the higher measured concentrations. All sources of fugitive dust are not accounted for in the $0.21 \mathrm{~kg}(0.46$ pound $)$ estimate. For example, wind erosion of contaminated soils is not included. However, given the comparatively low emissions and limited accuracy of the model used to predict the concentrations, the predicted results are considered reasonably accurate. Currently, USEPA requires the site to use the estimated values in its calculations for compliance with NESHAP.

\section{Soil Sampling for Uranium}

Site technicians take annual soil samples at the air monitoring stations and 011 , it locations to evaluate changes in uranium concentrations that might occur through deposition, soil resuspension or other mechanisms (see Figure 24 for sampling locations). Any uranium found in the soil may be naturally occurring, added by fertilizers, or a result of site operations. The amount of uranium naturally present in rocks and soils varies greatly (see Figure 25). For example, out of twelve samples collected throughout Ohio, the range of uranium-238 concentrations was $0.76 \mathrm{pCi} / \mathrm{g}$ to $2.2 \mathrm{pCi} / \mathrm{g} .{ }^{25}$ (The total radioactivity from uranium would be about twice this range because naturally occurring uranium in soil typically contains equal amounts of uranium-238 and uranium-2.34 radioactivity.) As a result, it is not possible to establish a single value for the background level of uranium and other minerals for an area such as near the Fernald site. While no DOE or USEPA gtiviciines or standards have been established for uranium in soil, $35 \mathrm{pCi} / \mathrm{g}$ or greater is recognized as a level at which to begin cleanup activities. However, this value may change depending on the future use of the site and remediation guidelines. ${ }^{26}$

To better evaluate the uranium concentration in soil, the site conducted a study to determine the amount of uranium naturally present in soil near the site. Soil samples were analyzed for a number of radionuclides; however, only uranium results are reported here. Results from this study show that the mean uranium concentration is $2.1 \mathrm{pCi} / \mathrm{g}$ with an upper limit (95\% tolerance limit) of $2.8 \mathrm{pCi} / \mathrm{g} .{ }^{23}$

As part of the soil sampling program, technicians collect cores of soll from undisturbed plots at two depths, $(2-5 \mathrm{~cm}(0-2$ inches) and 5-10 cm (2-4 inches), taking care to exclude grass from the soil samples. Results show that uranium concentrations in the soil samples taken at two onsite locations ranged between 6.9 and 18 

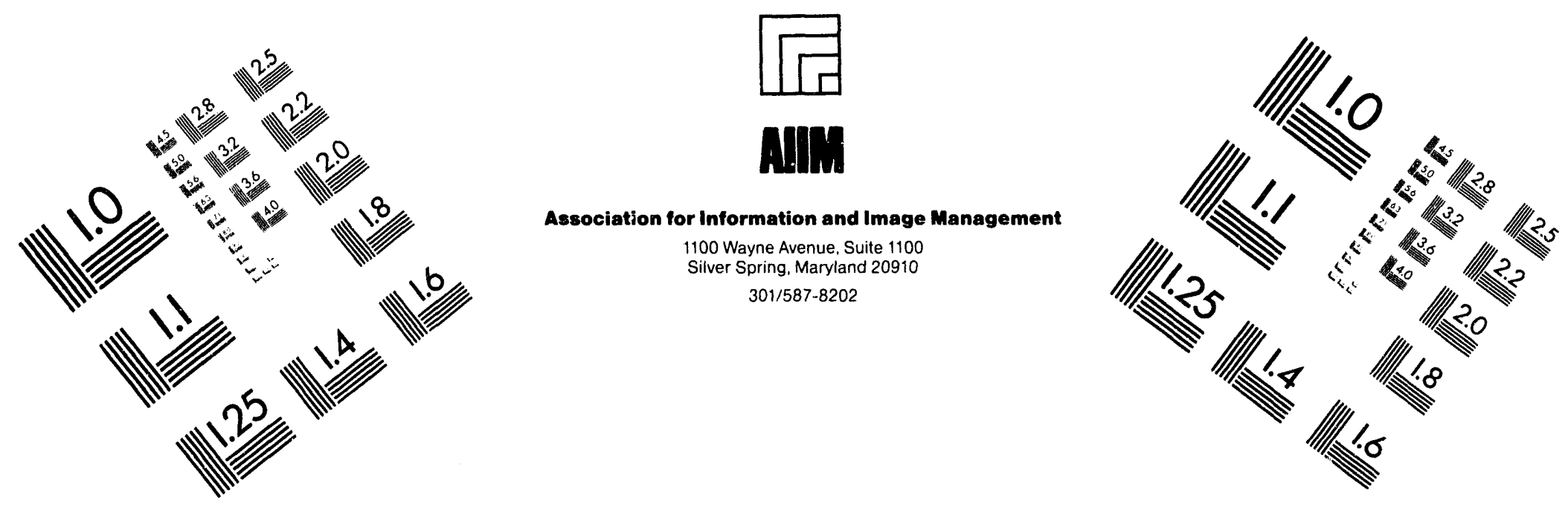

\section{Centimeter}

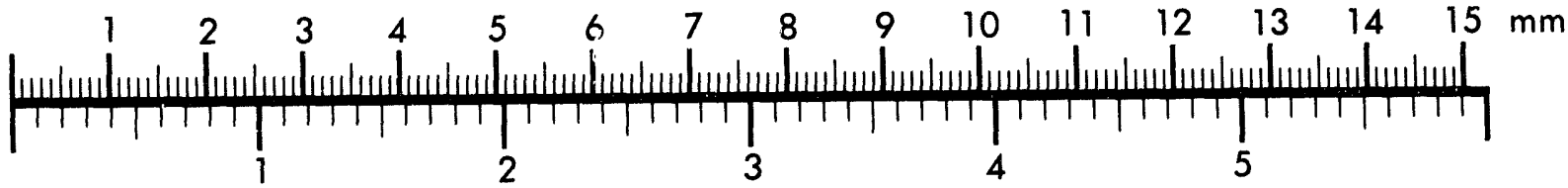

Inches
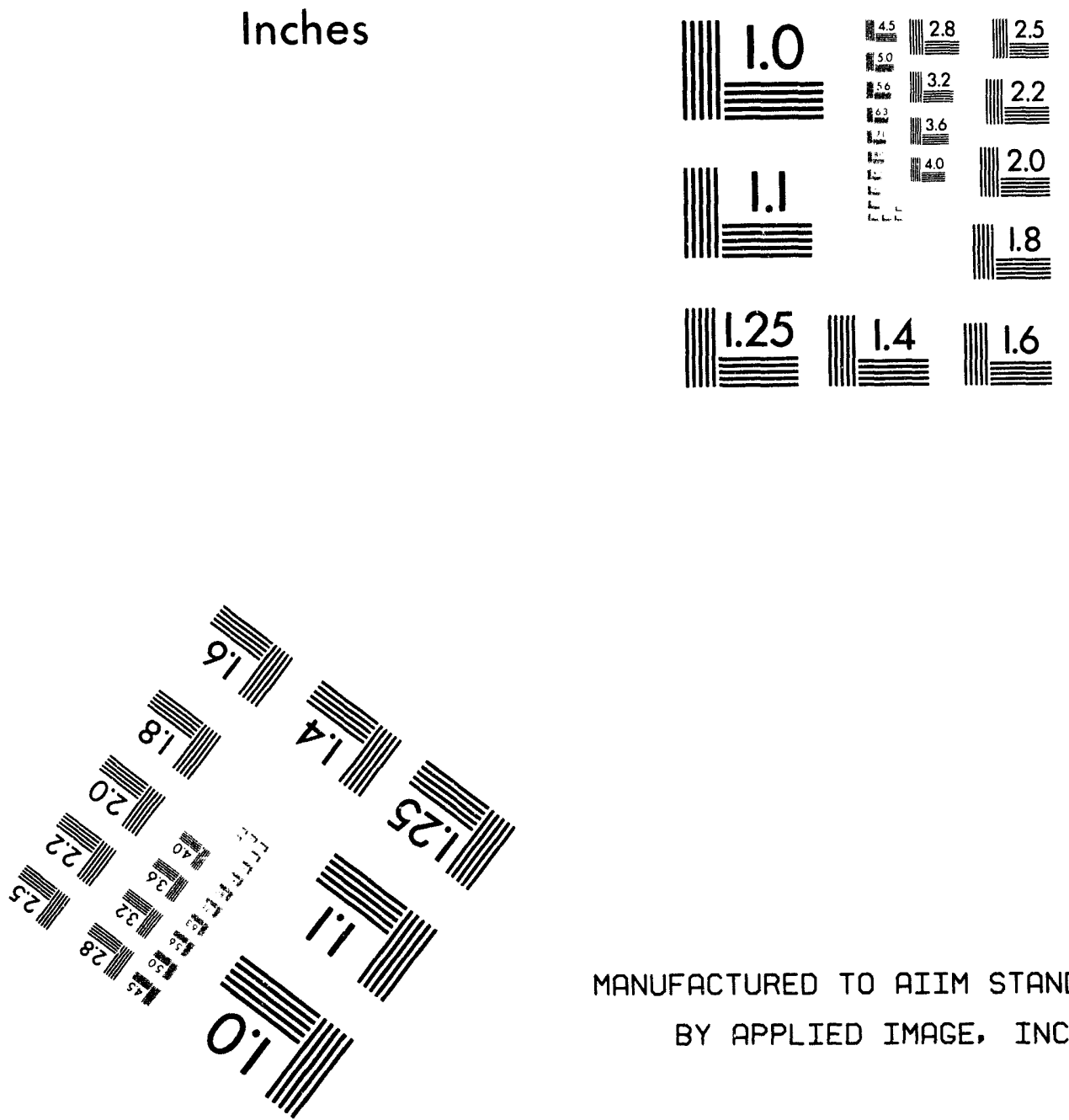

MANUFACTURED TO AIIM STANDARDS

BY APPLIED IMAGE, INC.

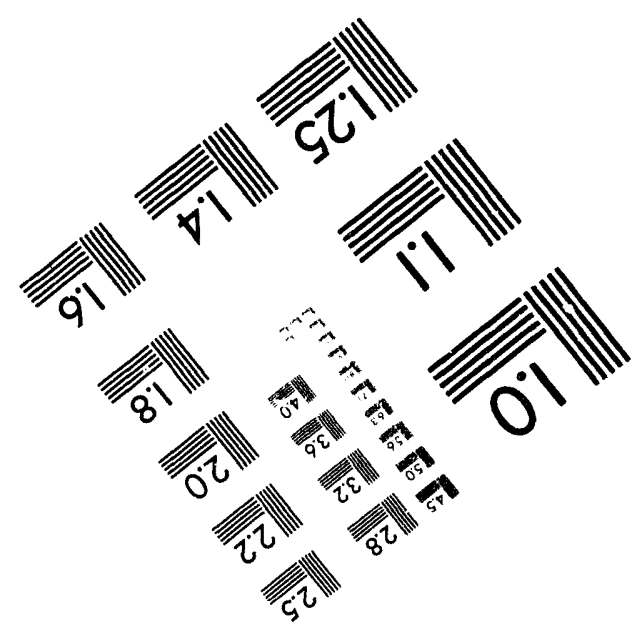



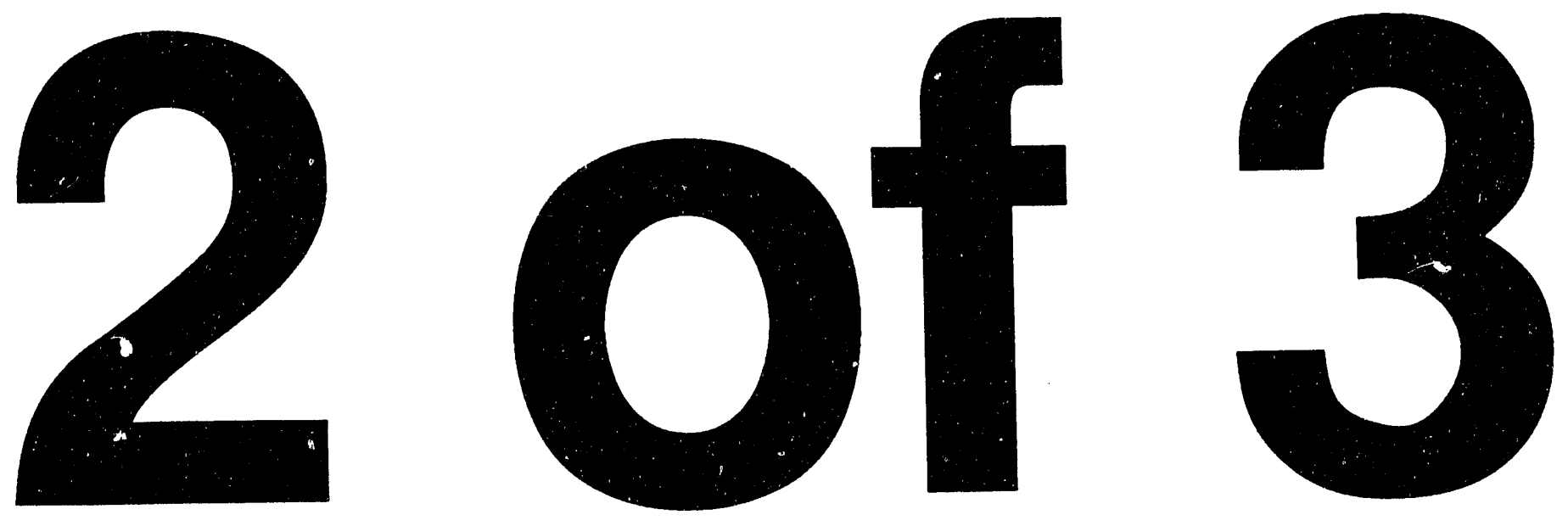
Figure 25: Range of Total Uranium Occurring in Surface Soils

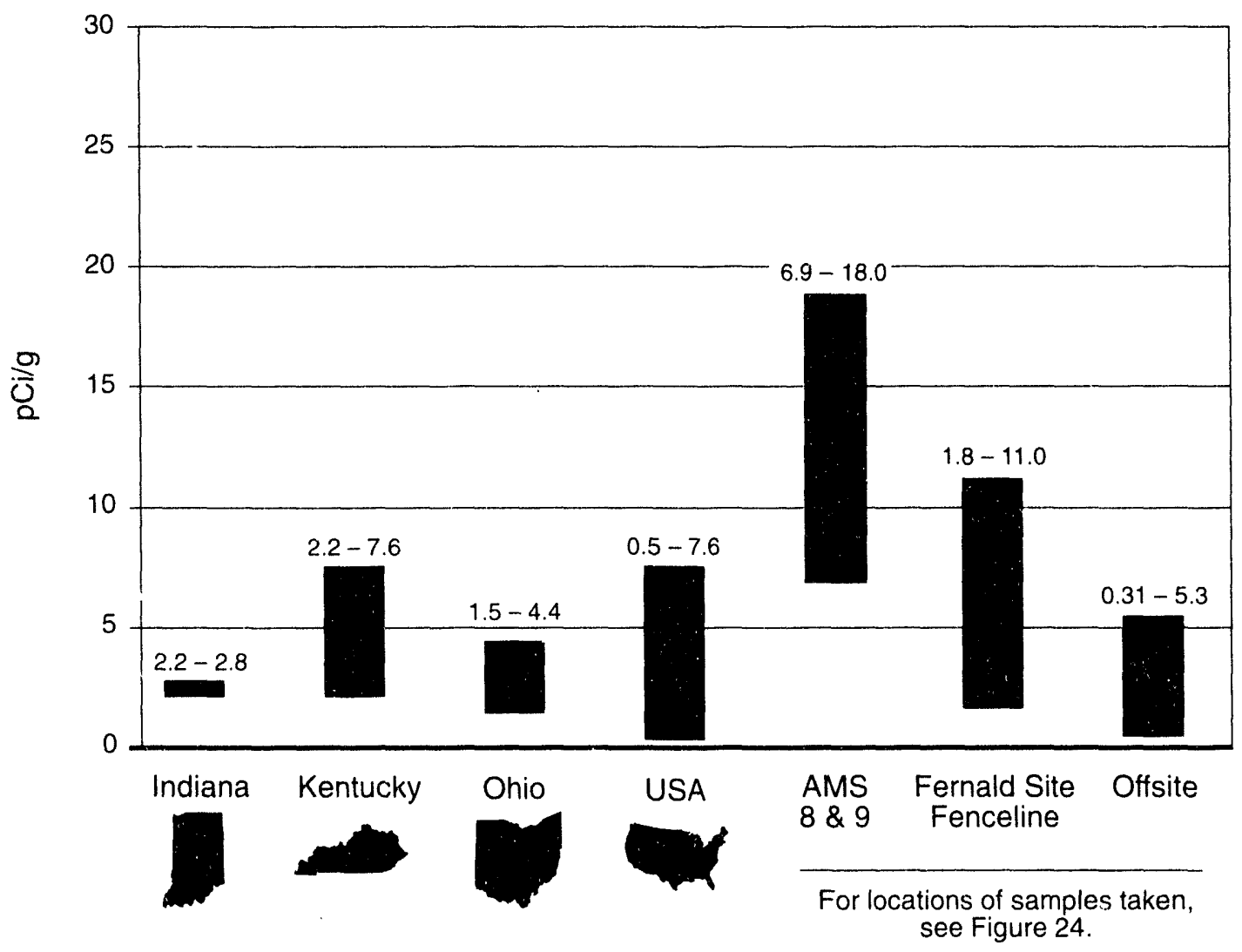

$\mathrm{pCi} / \mathrm{g}$ dry weight, while samples collected along the fenceline ranged between 1.8 and $11 \mathrm{pCi} / \mathrm{g}$ dry weight (see Table 6 on page A-9). The higher concentrations in onsite soil are indicative of the soil contamination known to exist, particularly in the northeastern quadrant of the site. The uranium concentration in offsite samples ranged from $0.31 \mathrm{pCi} / \mathrm{g}$ dry weight at sample location 36 to $5.3 \mathrm{pCi} / \mathrm{g}$ at sample location 30, which is northeast of the site. Above-background concentrations at sampling locations north and northeast of the site have been reported in past annual reports and are probably the product of airborne emissions and deposition during the period of uranium production. With the exception of the several locations north of the site, results from other offsite locations are within the range of naturally occurring uranium concentrations in Ohio soil.

\section{Grass Sampling for Uranium}

Uranium contamination in vegetation may result from transfer of uranium from the soil through absorption by the plant, deposition of eroded soil, or from uranium deposited on the surface of the plant from the air. As a general rule, uranium is not selectively absorbed by plants since it serves no useful purpose in the plant's 
metabolic processes; however, small amounts of uranium may be absorbed through a plant's normal growth processes. Fernald site personnel analyze grass for uranium to determine if airborne emissions are affecting the uranium concentration in grass.

Samples of grass were collected at the same locations as soil. Subsamples of grass are collected from the area around the soil sample location and then combined to form a composite sample. Each grass sample was a composite of at least three subsamples clipped near ground level. The composite samples each weighed about 500 grams ( 1 pound). An offsite laboratory air-dried and then analyzed the samples for uranium.

Standards have not been established for uranium in grass; however, comparing results of samples collected at the site with the results of samples collected of fite and distant from the site provides a means to evaluate the impact of site emissions on uranium concentrations in grass.

In addition to soil sample results, Table 6 on page A-9 reports the following uranium concentrations in onsite, fenceline, and of fsite grass samples:

- Onsite and fenceline results ranged from 0.017 to $0.72 \mathrm{pCi} / \mathrm{g}$ dry weight, and

- Offsite results ranged from 0.004 to $0.026 \mathrm{pCi} / \mathrm{g}$ dry weight.

The results indicate that uranium concentrations are higher at onsite and fenceline locations. The onsite grass concentrations are better correlated to local airborne uranium concentrations than soil concentrations, which suggests that deposition is the source of the higher concentrations.

\section{Produce Sampling for Uranium}

As mentioned in Chapter One, the Fernald site is surrounded by farmland. Homegrown sweet corn and tomatoes are two of the major crops sold from roadside stands within three miles of the site. Local residents also grow and sell bects, potatoes, apples, lettuce, pumpkins, cucumbers, and peppers.

With air emissions reduced to very low levels, the possibility of uranium contamination in produce that is caused by air depositicn is also very low. While washing the produce before eating removes any surface contamination which may be present, some uranium may be taken up by plants through their root systems and incorporated into their edible portions. Uranium detected in produce may be uranium that is naturally occurring in the soil, added by fertilizers, or deposited on the ground from airborne emissions.

Technicians sample produce each year to determine if uranium concentrations in produce grown near the site ( $(0-5 \mathrm{~km}$ or $0-3$ miles) are higher than concentrations in produce grown at distant locations (11-42 km or 7-26 miles) and are, therefore, a pathway of exposure from site emissions (see Figure 26 for sampling locations). 


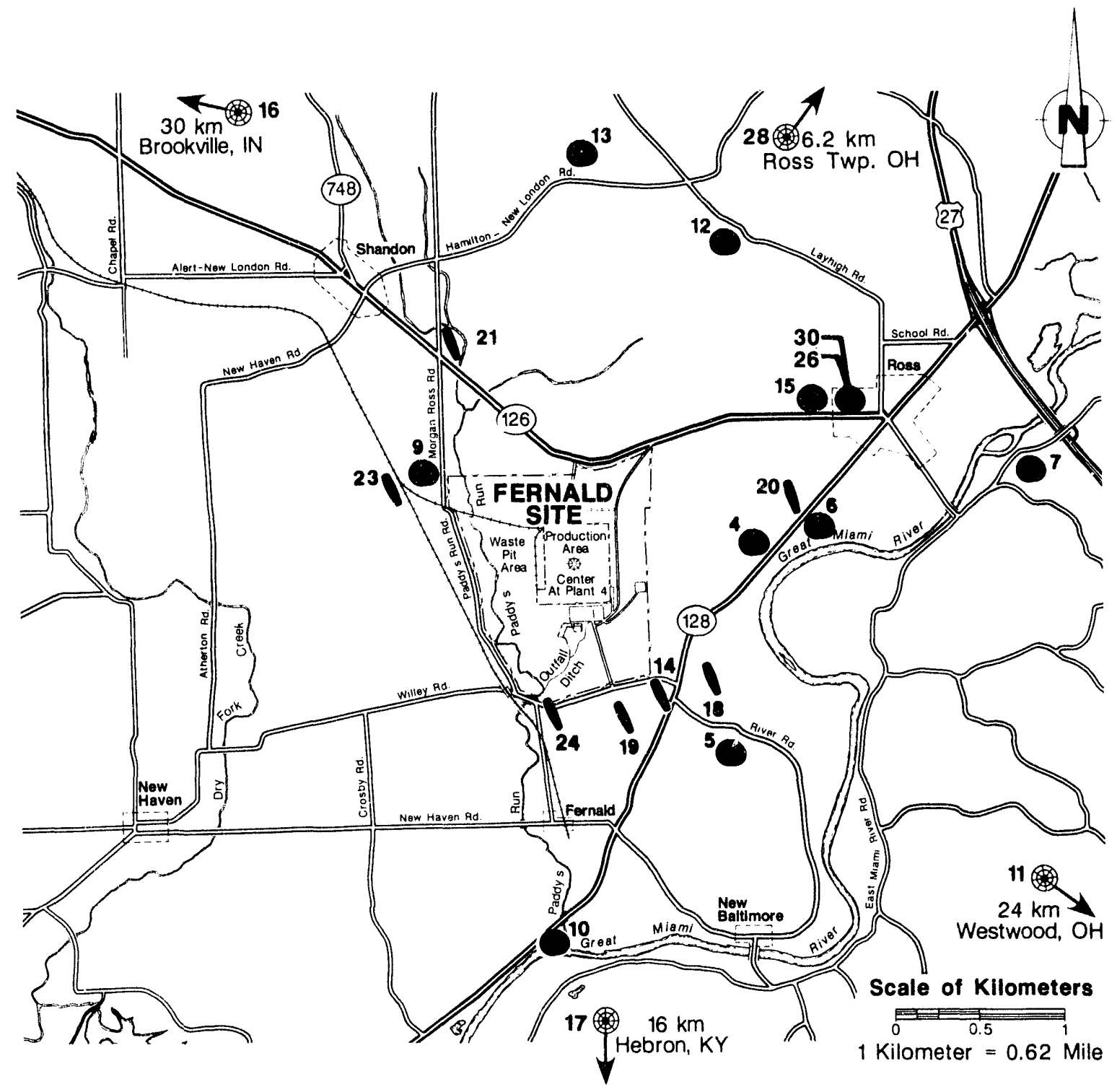

\section{LEGEND}

Sampling Locations:

- Cash Crop

Garden Produce $\times-\times$ Plant Perimeter

$x-x-x$ Production Area Perimeter

$\leftarrow$ Distance from Center of Production Area to Sampling Locations off Map 
The sample results are then used to estimate the potential dose to people from this component of the air pathway (see Chapter Seven).

The results of the produce and soil sampling program are reported in Table 7 on pages A-10 and A-11. In general, uranium concentrations varied greatly for each type of produce. A comparison between the uranium concentrations in corn and tomatoes grown near the site with concentrations in corn and tomatoes grown distant from the site determined that the average concentrations were higher in corn and tomatoes grown distant from the site. These comparisons suggest that there is no substantial impact today from past or current Fernald site emissions on produce grown in the area.

Technicians also sample the soil in which the produce is grown. This sampling is in addition to the soil sampling described earlier and is conducted to compare uranium concentrations found in soil with the concentrations found in produce. To date, no strong correlation between uranium concentrations in soil and produce has been established. Uranium concentrations in the soil taken along with produce ranged from 0.4 to $2 \mathrm{pCi} / \mathrm{g}$ and were within the range of naturally occurring uranium concentrations in area soils.

\section{Milk Sampling for Radionuclides}

Even though uranium is not normally concentrated in milk, the site monitors cows' milk as a component of the air pathway in response to public concerns about the dairy farm located next to the Fernald site. In 1993, technicians collected monthly samples of milk from the dairy adjacent to the site, as well as milk from a dairy in Indiana about $37 \mathrm{~km}$ ( 23 miles) west of the Fernald site. The milk samples were then frozen and shipped to an offsite laboratory for uranium analysis. In addition to monthly uranium analyses, once a year a set of milk samples is analyzed for radioactive materials present in trace concentrations (radium, thorium, etc.) in site emissions.

Table 8 on page A-12 presents the data from monthly milk sampling in 1993. In general, the results show uranium concentrations in milk from the local dairy were comparable to the uranium concentrations measured in milk from the background dairy in Indiana. In fact, the average concentration at the background dairy was higher than the concentration at the local dairy.

Table 9 on page A-13 presents the results of the trace radionuclide analyses from milk. Laboratory difficulties in analyses of trace radionuclides resulted in suspect data for beryllium-7, bismuth-214, lead-214, radium-228, and strontium-90. However, the results show that the concentrations of radionuclides in milk from the local dairy are similar to the concentrations in milk at the background dairy. 


\section{Monitoring for Direct Radiation}

Direct radiation (X-rays, gamma rays, energetic beta particles, and neutrons) originates frem sources such as cosmic radiation, naturally occurring radionuclides in soil, worldwide fallout, and radioactive materials at the Fernald site. The largest source of direct radiation at the site is the material stored in the K-65 silos. Gamma rays and $X$-rays are the dominant types of radiation emitted from the silos. Energetic beta particles and neutrons are not a significant component of direct radiation at the Fernald site because uranium, thorium, and their decay products do not emit this radiation at levels that create a public exposure concern.

Direct radiation levels at and around the site are continuously measured at 29 locations with thermoluminescent dosimeters (TLD). TLDs absorb and store the energy of direct radiation within the thermoluminescent material. By heating the thermoluminescent material under controlled conditions, the stored energy is released, measured, and correlated to the amount of direct radiation. Figure 27 shows the location of the TLD monitoring points. These monitoring points were selected based on the need to monitor the K-65 silos, the site boundary, and several of fiste locations, including background locations. Three TLDs are placed at each monitoring location for a three-month period, yielding more reliable quarterly measurements.

Results of direct radiation measurements for 1992 and 1993 are provided in Table 10 on page A-14. Direct radiation fields vary from one location to another because of the differences in the terrestrial and cosmic components of natural background radiation. For example, varying concentrations of naturally occurring radium, thorium, and their decay products in soil result in different measured radiation levels. Measurements of direct radiation indicate that levels are higher in the area near the K-65 silos as expected. However, these levels are clearly lower than radiation levels measured in 1991 prior to the addition of the bentonite layer within the K-65 silos. An estimated dose from direct radiation is provided in Chapter Seven.

\section{Monitoring for Nonradioactive Pollutants}

OEPA requires an estimate of emissions from the Boiler Plant as part of the site's effort to demonstrate compliance with the Clean Air Act. The site estimated the amount of nonradioactive pollutants including sulfur dioxide $\left(\mathrm{SO}_{2}\right)$, nitrogen oxides $\left(\mathrm{NO}_{x}\right)$, and carbon monoxide (CO) and measured the shade, or density, of particulate emissions from the coal-fired boilers. Shade, or density. is also called opacity and is a measure of how much light is blocked by particulates present in stack emissions. 


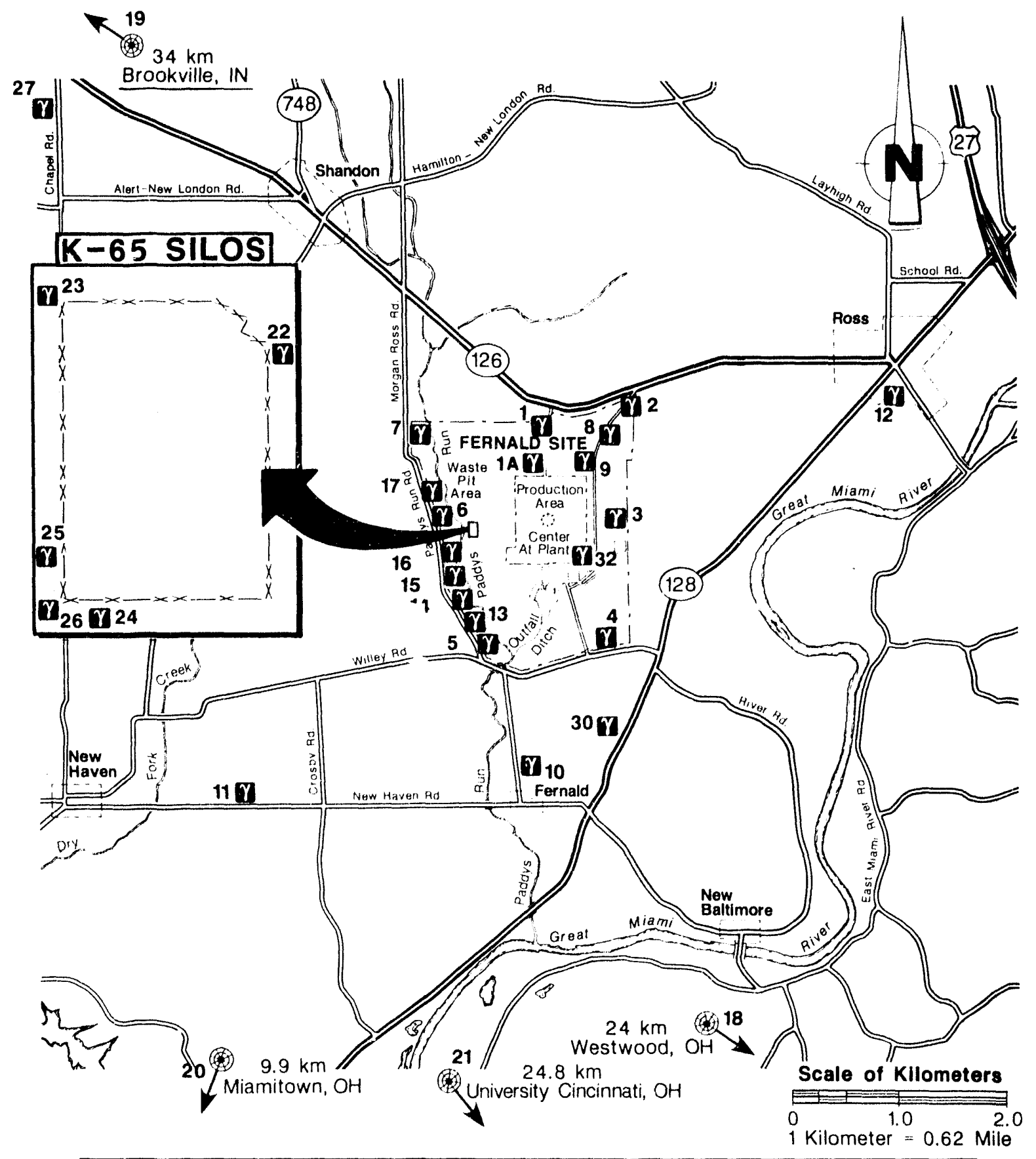

\section{LEGEND}

$\boldsymbol{\gamma}$ Dosimeter Location

-Distance from Center of Production Area to Dosimeter Locations off Map
- Plant Perimeter

$-\infty-x$ Production Area Perimeter 
In order to estimate $\mathrm{SO}_{2}$ emissions, scientists regularly determine the sulfur content of the coal. Using this information and the total amount of coal burned, the amount of $\mathrm{SO}_{2}$ emissions can be calculated. For $1993, \mathrm{SO}_{2}$ emissions were calculated to be $290,000 \mathrm{~kg}\left(630,000\right.$ pounds). ${ }^{27}$ This was well below the allowable limit of 1.6 million $\mathrm{kg}$ ( 3.5 million pounds) calculated from information in the Permit to Operate issued by OEPA.

The $\mathrm{NO}_{\mathrm{X}}$ emissions are estimated using USEPA-developed emission factors. Nitrogen oxide emissions for 1993 were estimated to be $150,000 \mathrm{~kg}(340,000$ pounds). To date, the State of Ohio has not set $\mathrm{NO}_{\mathrm{x}}$ or $\mathrm{CO}$ limits for Fernald site industrial

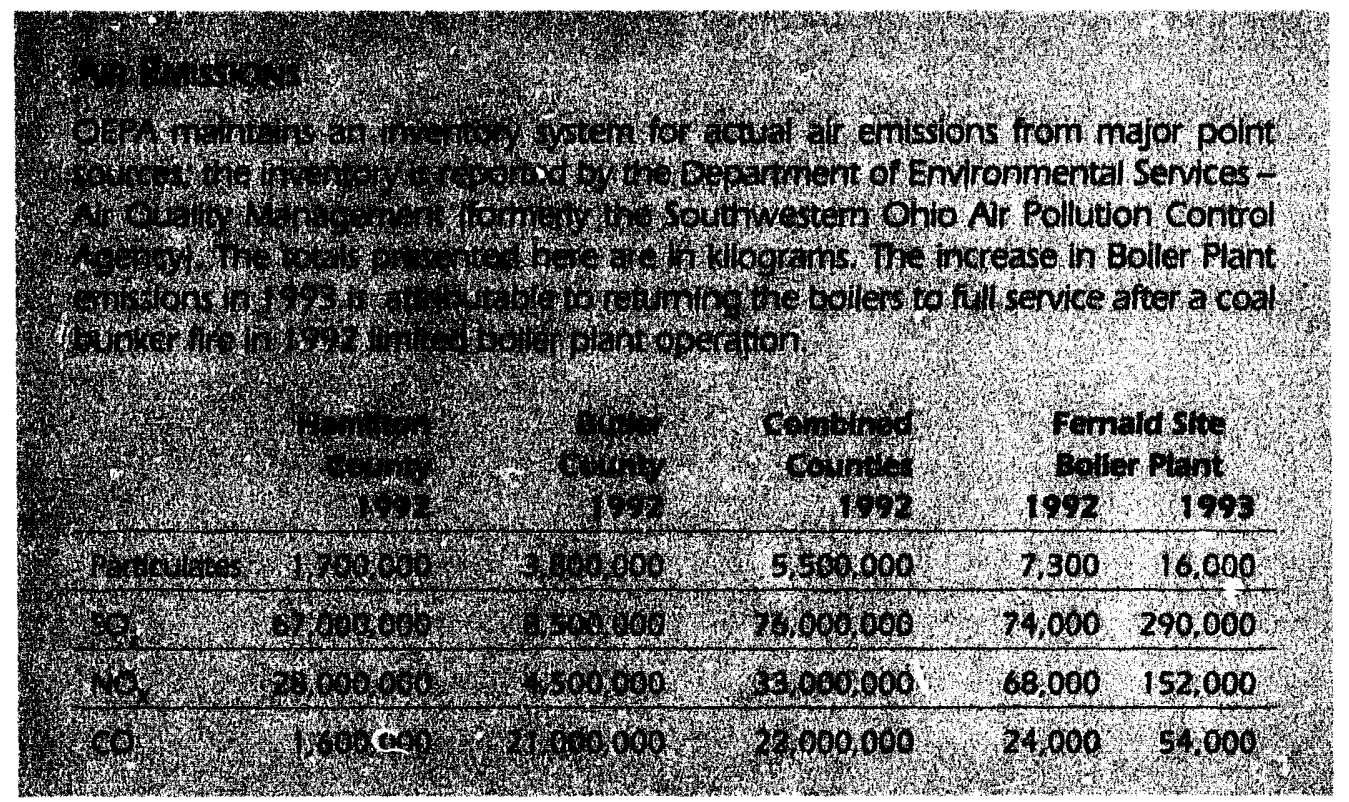

processes. Carbon monoxide emissions were estimated using USEPAdeveloped emission factors. Carbon monoxide emissions in 199.3 were estimated to be $54,000 \mathrm{~kg}(120,000$ pounds).

Electrostatic precipitators reduce particulate emissions from the Boiler Plant. These emissions were estimated to be $16,000 \mathrm{~kg}(36,000$ pounds) for 1993. This estimate was based on emission factors developed from stack testing in 1988. The opacity of the emissions from the two site coal-fired boilers were continuously monitored by instruments designed for that purpose. During 1993, the boilers operated 11,128 hours, and 111.280 measurements were made and recorded at six-minute intervals. A total of five excursions failed to meet the opacity standard. These excursions were brief, typically less than 18 minutes in length, and associated with boiler start up or load changes.

In addition to directly affecting concentrations of contaminants in soil, grass, and other media discussed in this chapter, the air pathway can indirectly influence contaminant concentrations in the liquid pathway. Stormwater runoff is one way materials deposited in the air can be transported into surface water such as Paddys Run. Eventually, these contaminants may affect groundwater quality as well. The next two chapters describe the Fernald site's monitoring program for the liquid pathways, beginning with Effluent and Surface Water Monitoring in Chapter Five. 


\section{Liquid Pathway: Effluent and Surface Water Monitoring}

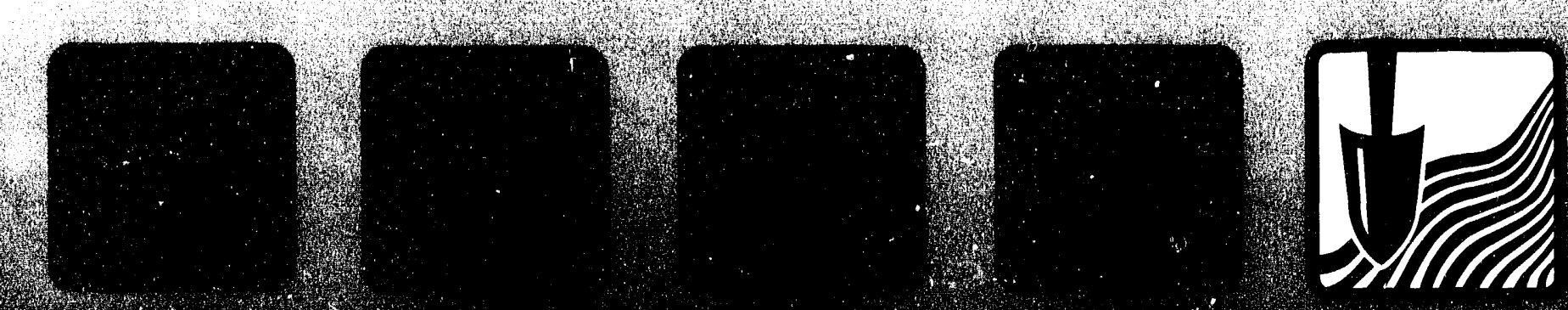




\title{
Liquid Pathway:
} Effluent and Surface Water Monitoring

\author{
The Fernald site investigates the effects of past and current operations on the \\ second major pathway, the liquid pathway. Since contaminants can leave the \\ site through the regulated liquid effluents and uncontrolled stormwater run- \\ off, this chapter discusses sampling methodologies and results used to evalu- \\ ate the site's effluents. It also discusses any impacts from the site on the Great \\ Miarni River and Paddys Run.
}

\section{Results in Brief: 1993 Liquid Pathway: Effiuent and Surface Water}

Effluent - Approximately $474 \mathrm{~kg}$ (1,044 pounds) of uranium were discharged to the Great Miami River during 1993. Of that total, $453 \mathrm{~kg}(998$ pounds) were from Manhole-175 and $22 \mathrm{~kg}$ (48 pounds) were from South Plume groundwater pumping. Approximately $109 \mathrm{~kg}$ (241 pounds) of uranium reached Paddys Run through uncontrolled stormwater runoff during 1993.

Surface Water - The liquid effluent discharged to the Great Miami River resulted in a slight increase in downriver uranium concentration from the upriver location. However, the downriver concentrations were consistent with 1992. Paddys Run continued to show effects of stormwater runoff from the site. Athough the average uranium concentration at the nearest offsite sampling location was higher than in 1992 , it was only $0.71 \%$ of the DOE guideline for drinking water, which is used for comparison purposes.

Sediments - Radionuclide concentrations in the Great Miami River and Paddys Run sediments for 1993 were consistent with previous years' data and did not indicate a build-up of radioactive pollutants in the sediment.

Fish - Uranium concentrations in 1993 were no greater in fish caught in the Great Miami River downstream of the site's effluent line than in those caught upstream.

NPDES - During 1993 there were only three violations of NPDES limits at Manhole-175, the final NPDES monitoring point before effluents are discharged to the river. Out of the yearly total of 4,020 NPDES samples taken at internal and external monitoring locations, only 11 were not within permit limits. 


\section{Monitoring for Radioactive Pollutants}

The first section of this chapter centers on the radioactive pollutants and begins with an examination of the liquid effluent simpling and analysis program. A discussion of the river and ereek surface water sampling program follows. The Fernald site conducts these programs because radionuclides in the regulated licjuid effluent and in uncontrolled stormwater runoff may be a source of radiation exposure to the public.

\section{Effluent Sampling for Radionuclides}

The site's liquid eflluents have been cattegorized into eleven basic soures. All site generated liquid effluents are monitored and, if necessary, treated before they leave the site. Figure 28 illustrates the flow of the effluents and where they are treated and monitored before they are discharged.

\section{Sources of Effluent During 1993}

The first two sources of liquid effluent are controlled contaminat d stormwater runoffs from the waste pit area and perimeter, which are collected and pumped to the Biodenitrification Surge Lagoon (BSL.).

The third source of liyuid effluert is perched groundwater, which is treated for volatile organic compounds (VOCs) and sent on to the Plant 8 Sump for further treatment.

The fourth source of effluent is the combination of sanitary sewage and liquid from the laundry. which is processed at the Sewage Treatment Plant to remove biological contaminants. After treatment, the liquid is sent to Manhole-175 and the sewage sludge is trucked to the Plant 8 Sump.

At the Plant 8 Sump, sludges are dewatered. The resulting licyuid is sent to the contaminated side of the General Sump, and the dewatered sludge is drummed and stored as a low-level radioactive waste.

The combination of plant effluent and pad stermwater is the fifth source of effluent, and it is sent directly to the contaminated side of the General Sump. All liquids from the contaminated side of the General Sump are combined and, if needed, atre sent to the Plant 8 Sump where they are treated. If treatment is not required, they are sent on (o) the BSI.

At the BSL, runoff mixes with liguid from the contaminated side of the General Sump and the combined liçuid eflluent is treated in the Biodenitrification Facility (BDN) towers to reduce nitrates. From there, the liquid flows through the BI)N effluent treatment system, after which the combined treated effluent flows to an Interim Advanced Wastewater Trealment (IAWWT) System where uranium maty be removed before it llows lo Manhole-175. 


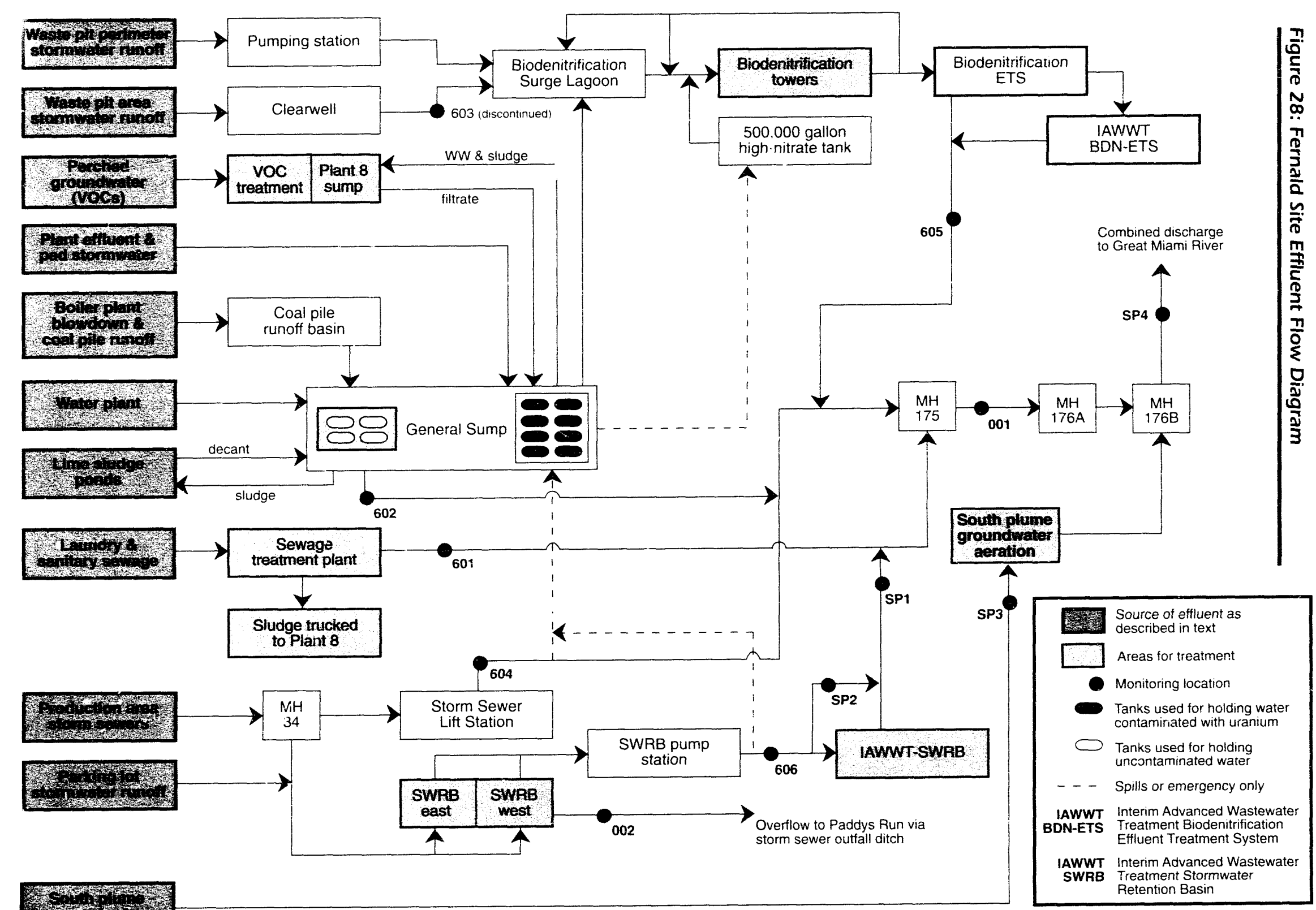


The sixth through the eighth sources of effluent are all collected in the noncontaminated side of the General Sump. Boiler plant blowdown and coal pile runoff are collected in the coal pile runoff basin and, after clarification, are sent to the noncontaminated side of the General Sump. Water plant effluent and Lime Sludge Pond decants are sent directly to the noncontaminated side of the General Sump. After settling, the liquid in the noncontaminated side of the General Sump is then sent to Manhole-175, and the sludge is sent to the North Lime Sludge Pond.

The ninth and tenth sources of effluent are produced from rain which has been collected by the production area storm sewers and parking lot runoff (see Figure 29). Stormwater runoff from the former production area is collected by a network of storm sewers that converge at Manhole- 34 . Normally all runoff is directed to the Stormwater Retention Basin (SWRB); but if needed, effluent can be pumped to Manhole-175 from the Storm Sewer Lift Station. At the SWRB the effluent mixes with runoff from the parking lot storm sewers and is allowed to settle befre bing pumped to an IAWWT. From there the effluent is sent to Manhole-175. A: Manhole175, the effluents are monitored, and sent to Manhole-176B.

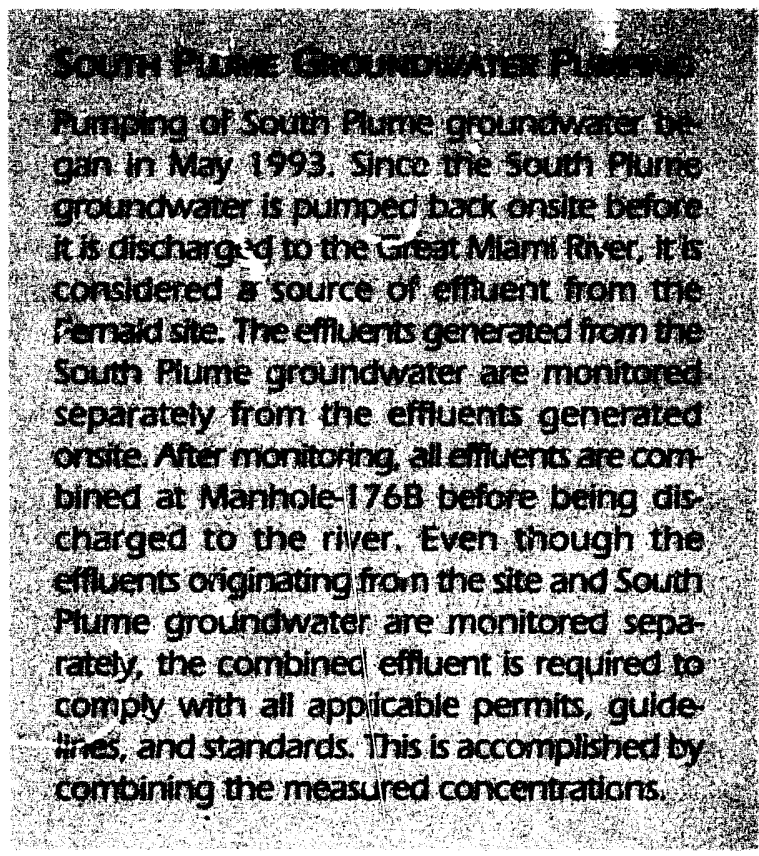

The final source of effluent is generated from the pumping of the South Plume groundwater. The South Plume groundwater is monitored at SP3 before being pumped to the South Plume Aeration building where it can be aerated if needed and then sent to Manhole-176B.

In summary, the Fernald site controls site-generated liquid effluents, monitors, and treats them as necessary before they all eventually enter Manhole-176B. There, the effluents combine to form a single liquid before the effluent flows to the Great Miami River.

On an average day during 1993, about 12 billion liters ( 3.1 billion gallons) of Great Miami River water flowed past the site's effluent line. ${ }^{8}$ The site discharged an average of 5.8 million liters ( 1.5 million gallons) of effluent, with 3.4 million liters ( 0.89 million gallons) coming from the South Plume and 2.4 million liters ( 0.65 million gallons) originating from Manhole-175, into the river each day. Therefore, on average, each liter of effluent discharged was combined with about 2,100 liters of river water.

\section{Sampling Methodologies}

The mixed effluent, described above, is sampled at Manhole-175 and SP3 by flow-proportional samplers, continuously operating devices that collect the amount of the effluent proportional to the volume of effluent flow. After every 24 hours of operation, the collected liquid is removed from the automatic sampler to provide a daily flo: $N$-weighted sample of the effluent (see Figure 30 ). 


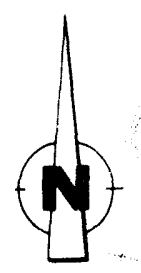

Scale of Meters

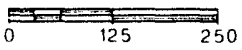

1 Meter $=3.281$ Feet

\section{LEGEND}

Shaded Areas are Collected $\times-x$ Plant Perimeter
and Eventually Discharged
to the Great Miami River
th


Figure 30: Continuous Sampling

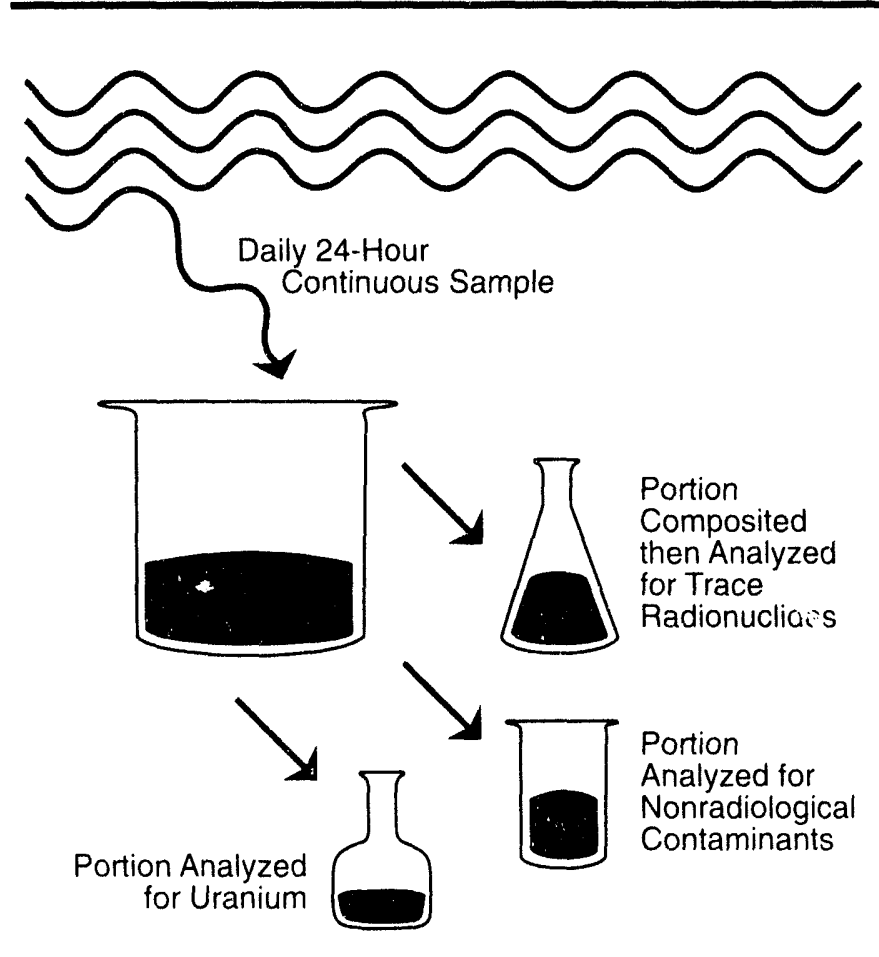

Scientists analyzed a portion of each daily sample of effluent flowing through Manhole-175 and SP3 to determine the amount of total uranium discharged to the Great Miami River. In addition, monthly composites are formed for Manhole-175 and SP3 by combining the month's daily samples at each location. The monthly composites were analyzed for four uranium isotopes and nine other radionuclides listed in Table 11 on page A-15. Composites, rather than daily samples, were analyzed because many of the radionuclides have been present in only trace amounts, and it is neither practical nor cost-effective to perform more frequent analyses for them.

The Fernald site also monitors any discharges to Paddys Run that occur from the overflow of the SWRB. Since the SWRB began operating in 1986. the amount of uranium entering the outfall ditch has been substantially reduced. During 1993 the SWRB did not overflow.

\section{Results of Laboratory Analyses}

Table 11 on page A-15 is a summary of the radionuclide analysis of the liculid effluent discharged to the Great Miami River. The table shows the total Curies discharged during 1993 and the average concentration (in $\mathrm{pCi} / \mathrm{L}$ ) of each radionuclide in 1993.

The average concentration of each radionuclide is compared to the Derived Concentration Guideline (DCG) or standard. DOE Orders state that a dose must be estimated based on all of the radionuclides present in the effluent. The annual average percentages of the DCG for each radionuclide, when added together (Manhole-175 and SP3 combined), must not exceed $100 \%$. When the total is above $100 \%$, the site is required to use the "best available technology" to reduce radionuclide concentrations in its effluent.

An Advanced Wastewater Treatment Facility is presently under construction to provide "best available technology" treatment of both stormwater and process wastewater before their discharge to the Great Miami River. Similar technology has been used at the SWRB with an Interim Advanced Wastewater Treatment facility. In 1993. another Interim Advanced Wastewater Treatment system began operation to extract uranium from wastewater discharged from the BSL. 
During 1993, a total of 0.27 Curie ( $474 \mathrm{~kg}$ or 1,044 pounds) of uranium was discharged to the Great Miami River. This was a decrease of $7 \%$ on an activity basis and an increase of $7 \%$ on a mass basis, in comparison to the 0.29 Curie ( $443 \mathrm{~kg}$ or 975 pounds) of uranium discharged to the river during 1992. However, the uranium contained in all effluents discharged from the site decreased from an estimated 595 $\mathrm{kg}(1,309$ pounds $)$ in 1992 to an estimated $583 \mathrm{~kg}$ ( 1,283 pounds $)$ in 1993. The total decrease may be attributed to the

Figure 31: Total Uranium Dischargeci from the Site, $1989-1993$

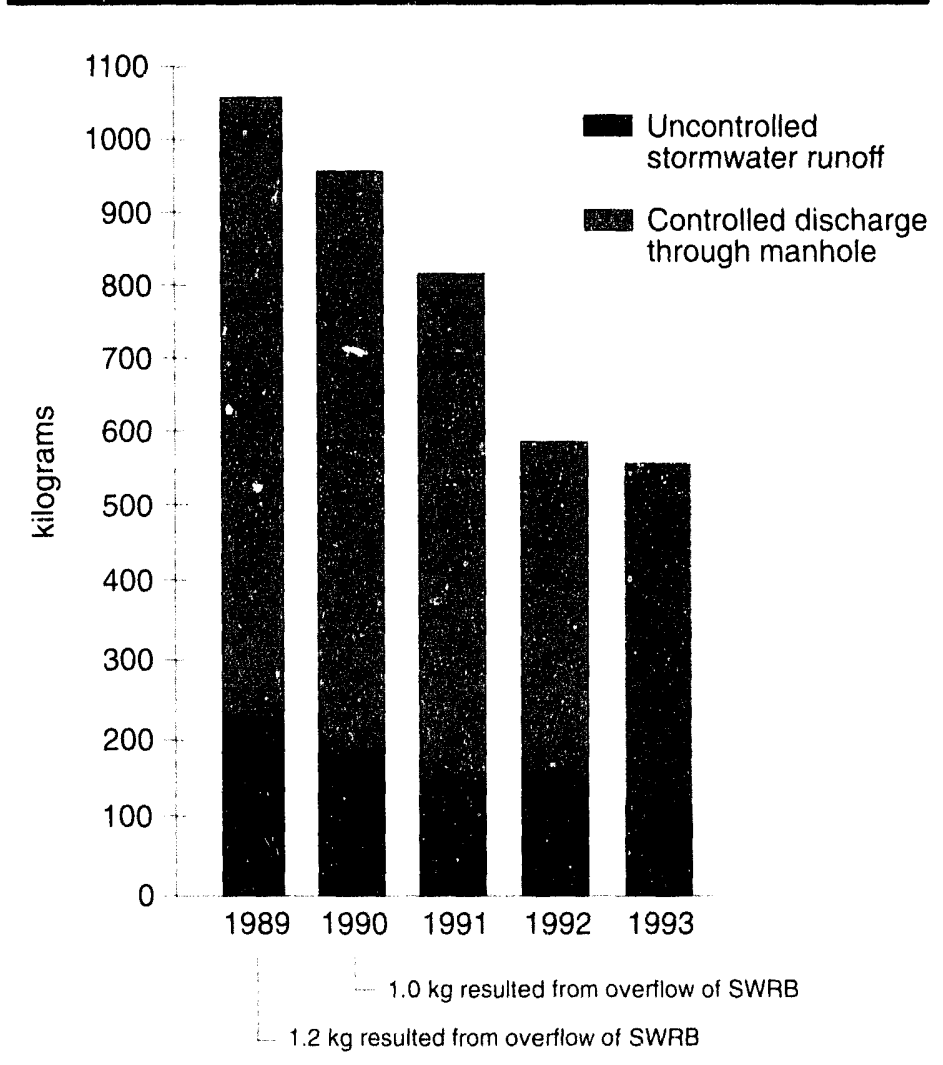
completion of the Waste Pit Area Stormwater Runoff project that collects runoff (which previously flowed uncontrolled to Paddys Run), allowing it to be treated before being discharged to the river. Comparisons of uranium discharges to the Great Miami river during 1993 and the four previous years are shown in Figure 31.

The Fernald site reports an estimate of uranium in uncontrolled stormwater runoff into Paddys Run to USEPA. Fernald site personnel had developed a general estimate of $2.8 \mathrm{~kg}$ ( 6.3 pounds) of uranium in the runoff to Paddys Run for every inch of rain. For 1993. the estimate of uranium in stormwater runoff to Paddys Run was reported as $109 \mathrm{~kg}$ (241 pounds). This estimate was based on the amount of precipitation recorded by the site meteorological system ( $98 \mathrm{~cm}$ or 39 inches). Actinium, radium, and thorium concentrations were all within acceptable limits. Their percentage of the applicable DCGs ranged from $0.0054 \%$ for thorium-231 to $4.8 \%$ for radium-228.

\section{Surface Water Sampling for Radionuclides}

The site's surface water sampling program measures the effects of two potential sources of contamination on local waterways: the discharge of liquid effluents into the Great Miami River and the effects of uncontrolled stormwater runoff into Paddys Run and overflow from the SWRB (which did not occur in 1993). Figure 29 on page 85 shows the area of controlled stormwater runoff. 


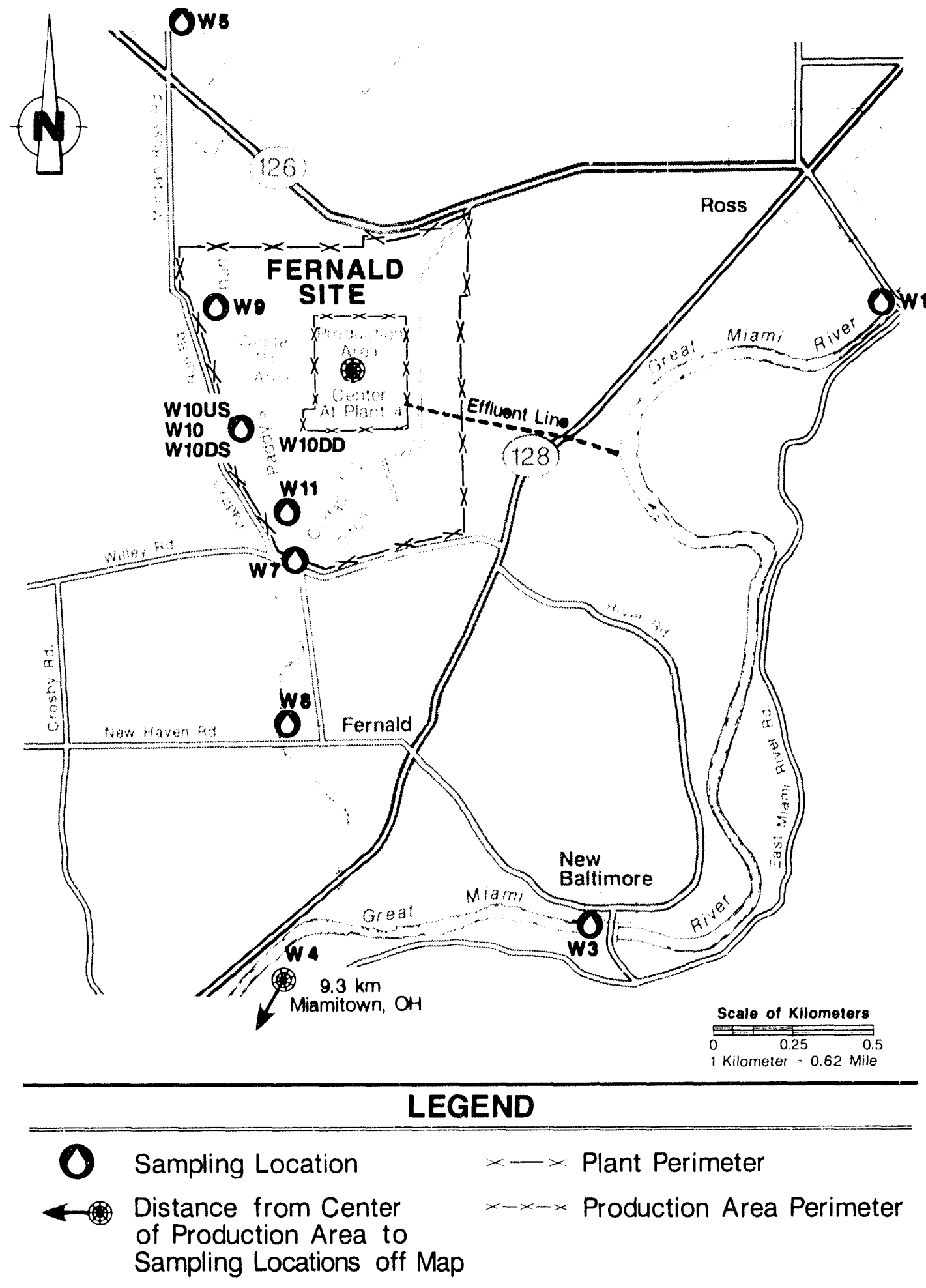




\section{Sampling Methodologies}

During 1993, surface water was sampled at the following locations identified in Figure 32:

- Three locations along the Great Miami River (W1 - upstream from the effluent discharge, W3, and W4);

- Five onsite locations along Paddys Run (W9, W10-US, WI(), WI()-DS, and WII);

- One location along the cirainage ditch originating near the Pilot Plant (WI)DD): and

- Three offsite locations along Paddys Run (W5 - upstream from the site, W7, and W8).

Each week, the onsite laboratory analyzed one of the daily samples from each river sampling location for total uranium. Portions of the daily samples collected along the Great Miami River were combined to form weekly and monthly composites for each location, which were then analyzed for radium-226 and radium-228. Six-month composites, taken from the individual monthly composites, were analyzed for cesium-137, strontium-90), and technetium-99.

Weekly grab samples were collected at the five onsite locations along Paddys Run, one location along the drainage ditch, one location upstream (north) of the site, and two locations downstream (south) of the site. All samples collected along Paddys Run were analyzed weekly for total uranium. Two-month composites of weekly samples from W5 were analyzed for isotopic radium, as were monthly composites at W7 (or W8 if there was not enough water at W7). Oftentimes there is not enough water present in Paddys Run to collect a sample.

Uranium concentrations at W10 have varied greatly. This may be due to the fact that uranium concentrations in surface water are not directly comparable over time due to different states of dilution as a result of varying precipitation and flow rates. Consequently, representative samples cannot always be obtained because the effluent from the drainage ditch often does not have sufficient time to completely mix with the water in Paddys Run to provide a homogeneous liquid for sampling. In order to account for this problem. three sampling locations (WI)-US - upstream of WI() and near the K-65 silos, W10-DD - along the drainage ditch, and W10-DS - just downstream of W1(0) were sampled.

\section{Results of Laboratory Analyses}

The radionuclide concentrations found in surface water samples collected during 1993 are summarized in Table 12 on pages A-16 and A-17. The data indicate that differences in uranium concentrations in the Great Miami River were very small. However, they are statistically significant. Average uranium concentrations at W3 and W4 (1.2 pCi/L) were well below the DOE guideline for drinking water (used for 


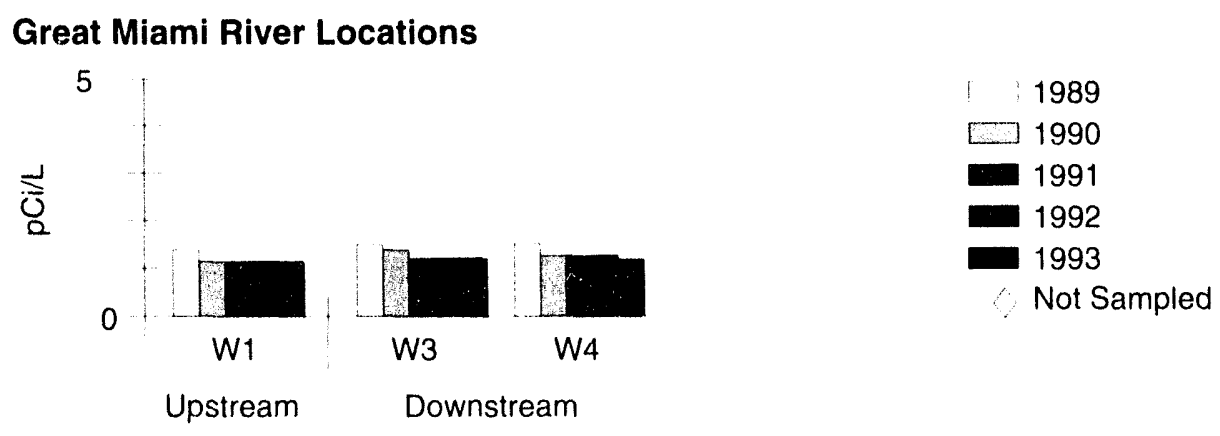

Paddys Run Locations
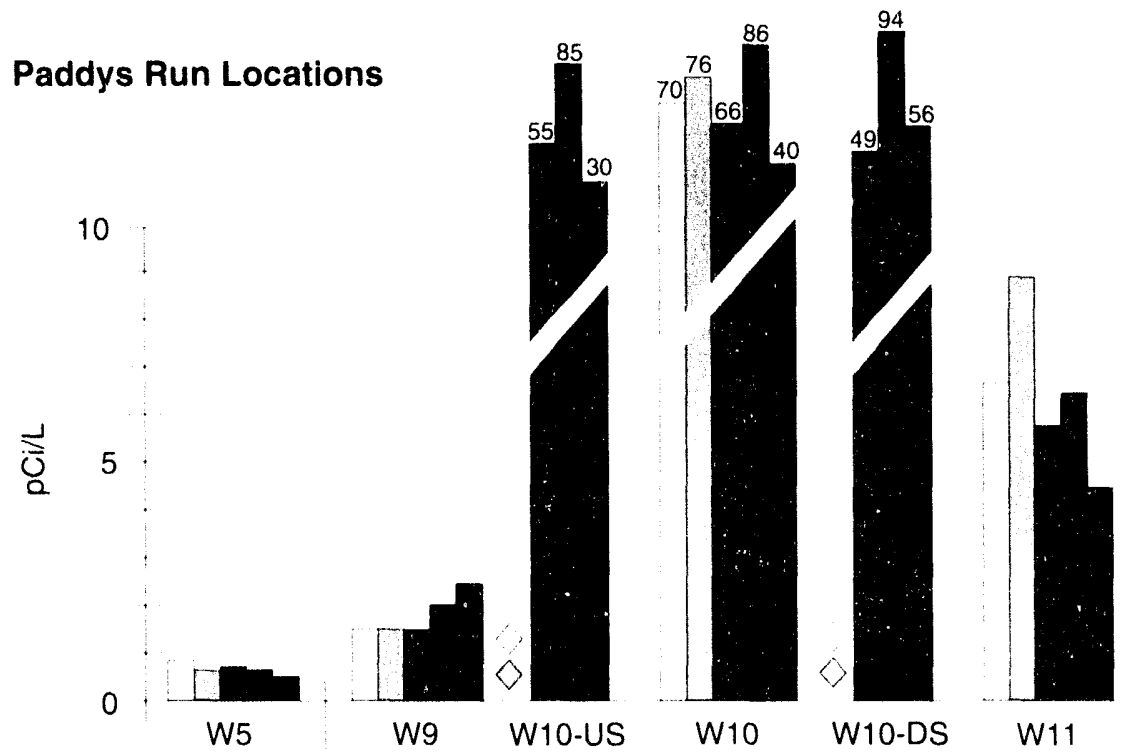

Upstream

Onsite

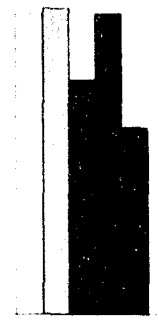

W7

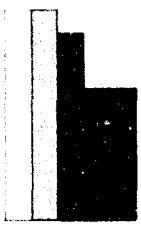

W8

Downstream

comparison purposes only). Both concentrations were at (0.22\% of the DCG. Figure 33 shows five-year trends of uranium concentrations in surface water from the Great Miami River and Paddys Run.

Surface water samples collected in 1993 from the Great Miami River and analyzed for radiun-226, radium-228, strontium-9(), cesium-137, and technetium-99 were consistent with previous years. These data support the results in Table 11, demonstrating that the concentrations of these radionuclides in the liquid effluent discharged to the river were very low and resulted in very little, if any, increase in the concentrations already present in the river. 
Environmental monitoring personnel used upstream sampling point W5 to determine concentrations of uranium and radium normally present in Paddys Run. The data indicate that the uranium concentrations found in this stream were significantly higher downstream (W7 and W8) of the site than they were upstream (W5). The average concentration at $\mathrm{W} 5$ was $0.67 \mathrm{pCi} / \mathrm{L}$ compared to $3.9 \mathrm{pCi} / \mathrm{L}$ at W7. However, average uranium concentrations at all Paddys Run monitoring locations were well within DOE guidelines for drinking water (again used for comparison purposes only), ranging from $0.44 \%$ of the DCG at W9 $1010 \%$ at W I()-DS. W I()-DD, leading into Paddys Run is $69 \%$ of the DCG.

High average values from W10-US, W10, and W10-DS are due to a few very high weekly results. The median value may better represent the actual conditions of the stream, rather than the average, because the median is not as easily changed by a few extreme results. The median values of these locations are $2.2 \mathrm{pCi} / \mathrm{L}$ at $\mathrm{W} 1($ )-US, 4.3 $\mathrm{pCi} / \mathrm{L}$ at WI0, and $1.3 \mathrm{pCi} / \mathrm{L}$ at WI()-DS. The elevated levels in WI()-DD, combined with the fact that the average uranium concentration at W10-DS and W. 10 is higher than W10-US, suggest that the drainage ditch from which W10-DD is collected contributed to the uranium concentrations in Paddys Run (see Table 12 on pages A-16 and A-17). The increase in both the median and average concentration from W9 to W10-US, indicates that factors other than the drainage ditch may have also influenced the uranium concentration levels in Paddys Run.

\section{Sediment Sampling for Radionuclides}

Contaminants present in surface water can setlle or precipitate and thereby accumulate in sediment. Sampling and analysis of sediments provide a way to evaluate possible cumulative effects of routine discharges of treated effluents into the Great Miami River and the effects of stormwater runofl' into Paddys Run.

\section{Sampling Methodologies}

Technicians collected sediment samples only at those locations where sediment was most likely to accumulate. In early August, samples were collected from the following locations identified in Figure 34:

- Eight locations at 10()-meter (33-foot) intervals along the Storm Sewer Outfall Ditch (SSOD):

- Nine locations allong the Greal Miami River;

- Twelve locations along Paddys Run north of the SSOD;

- Twelve locations along Paddys Run south of the SSOD); and

- Four background locations along Paddys Run, north of the site.

Technicians collected one sample at each location. All samples were taken from strategically chosen locations to ensure that they were representative of the most recent and greatest imount of sediment deposited. 


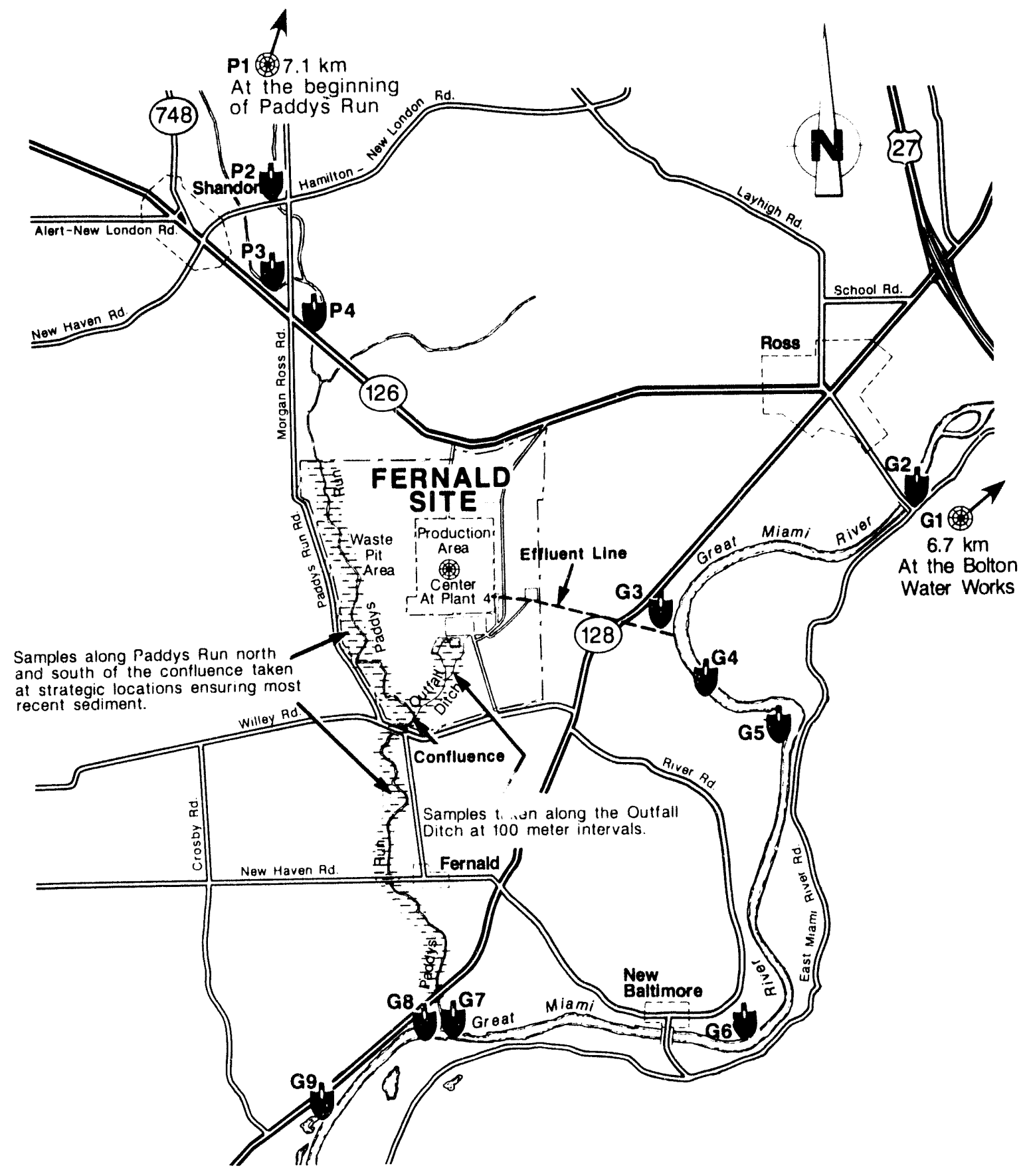

\section{LEGEND}

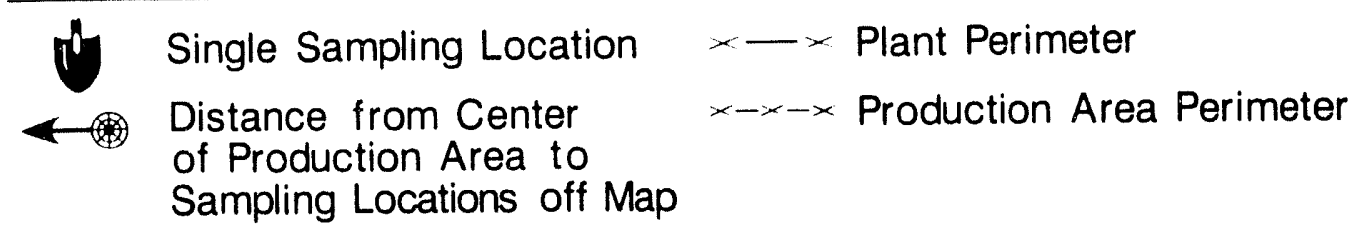


In 1993, all sediment samples were analyzed for total uranium. Samples taken from the SSOD, Paddys Run above the SSOD, and Paddys Run background were also analyzed for radium-226 and isotopes of thorium. There are currently no DOE or USEPA guidelines or standards for uranium or other radionuclides in sediment.

\section{Results of Laboratory Analyses}

The data in Table 1.3 on page A-18 show there were no noticeable differences in the concentration of uranium and other radionuclides found in sediment samples collected from the Great Miami River upstream and downstream of the site's effluent discharge line. Therefore, the site's liquid effluent discharges did not cause any discernible increase in the levels of radionuclides in Great Miami River sediment.

Radium and thorium results for 199.3 were consistent with those found in recent years. Total uranium results from Paddys Run locations in 1993 were also similar to those in 1992. However, the average uranium concentration in the outfall ditch 6.5 $\mathrm{pCi} / \mathrm{g}$ ) was still above background levels. Uranium concentrations in individual locations along this ditch have been elevated in previous years as well, probably because of runoff from onsite stormwater flowing into the outfall ditch over th years.

\section{Fish Sampling for Uranium}

The fish population of the Great Miami River is another component of the liquid pathway. Fernald site personnel, with the help of a research team from the University of Cincinnati, have been sampling fish in the river for ten years. The sampling team collects fish by electrofishing. This method is among the most efficient methods of collecting fish samples unbiased with respect to size and species.

\section{Sampling Methodologies}

In August 1993, the team collected over 224 fish representing 26 species from three sites along the Great Miami River (see Figure 35):

- River Mile (RM) 38 - below the Route 127 bridge, north of Hamilton;

- RM 24 - at the Fernald site effluent discharge; and

- RM 19 - at the outfall point of Paddys Run.

The 1993 collection was made at the same time of year as in 1992. RM 38 is used as a background location because the fish population is physically isolated from downstream activity and migration of fish by the two Hamilton dams, whereas the other locations are not. Location RM 24 and RM 19 have the potential to be influenced by the backwater species that migrate up from the Ohio River. The variety of lish species collected included gizzard shad, skipjack herring, mooneye, golden redhorse, shorthead redhorse, spotin shiner, largemouth bass, striped bass, smallmouth hass, white bass, immature bass, river carpsucker, highfin carpsucker, quillback carpsucker, drum, bluegill, hybrid longear and bluegill, longear sunfish, green sunfish, immature sunfish, sauger, carp, mirror carp, channel catfish, flathead catfish, and brown bullhead. 


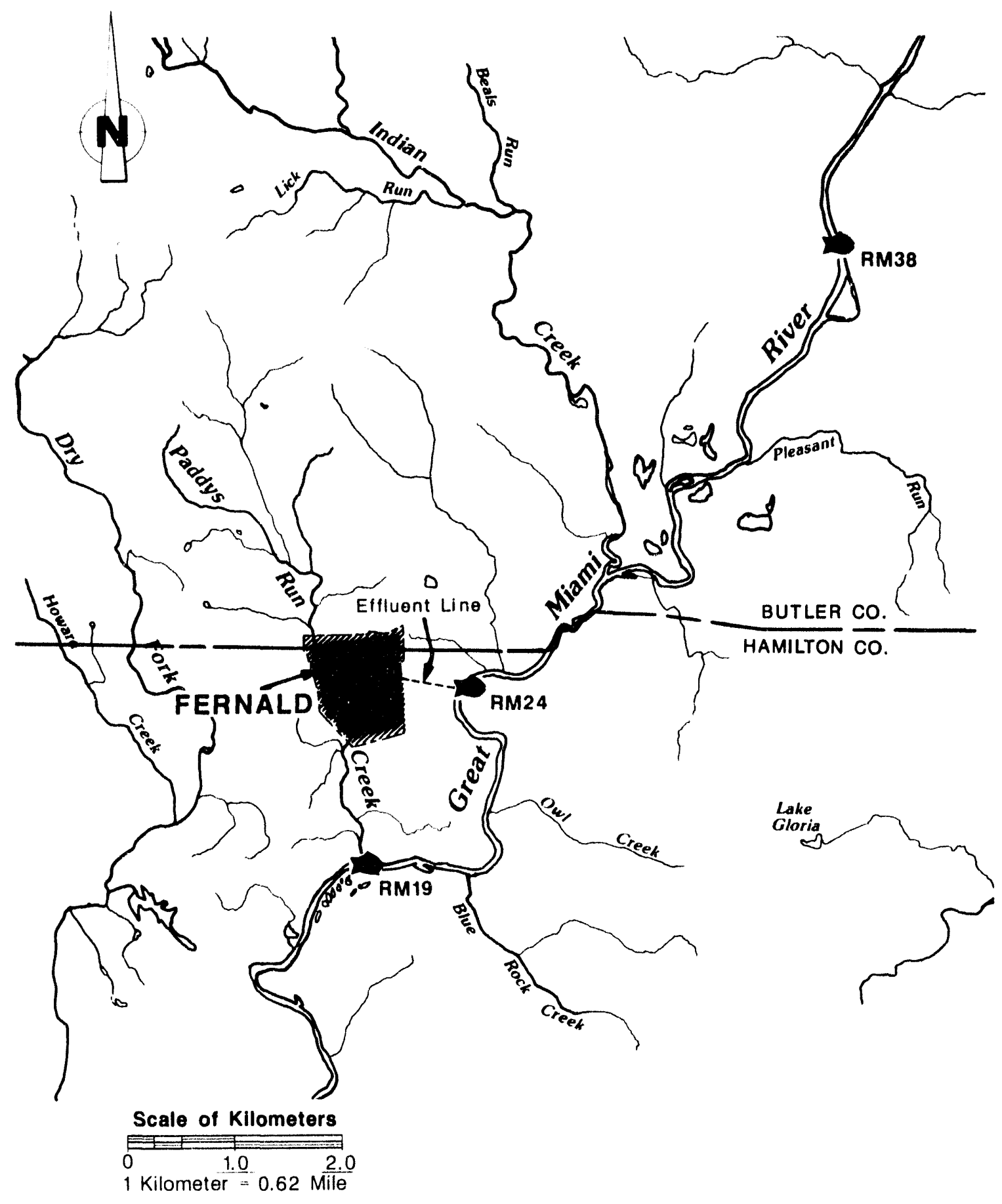

LEGEND 
The lish population of the Great Miami River has been stable over the course of this study. In 1993, diversity of hish caught was nearly the same at all locations. The fish species richness at $r$ ch site was proportional to the number of fish caught. The lish species appear to be in similar health regardless of sampling location..$^{2 \times}$

\section{Results of Laboratory Analyses}

Table 14 on page $A-19$ contains the average uranium cencentrations reported in fish from all three sampling locations. Since all uranium concentrations in lish were not normally distributed. the geometric mean was provided rather than the arithmetic mean (average) in order to make meaningful comparisons between locations and/or families. Statistical comparisons were made to determine:

- If the uranium concentrations of all fish in general caught at RM 38 (background location) were different from the fish caught at RM 24 and RM 19 taken collectively.

- If the uranium concentrations of all fish caught in any one site were greater than the fish caught from the other two locations taken individually, and,

- If any one family of fish had higher uranium concentrations when sampled at one location as opposed to the other two locitions.

It was statistically proven with $p \leq 0.0 .5$ that:

- No single location had statistically greater uranium concentrations than the other two locations taken collectively:

- In general, all fish caught at RM 24 had statistically higher concentrations then those caught at RM 38 and RM 19 taken individually; and

- Families one and two were found at no locations with statistically higher concentrations than the other two locations, families three and five displayed statistically higher concentrations at RM 24 then at RM 19 (family five was not found at RM 38), and family four showed statistically higher concentrations at RM 19 then at RM 38 (RM 24 provided only one fish from family four). ${ }^{x /}$

Overall, the 1993 total uranium results are consistent with or lower than results from recent years at all locations. The estimated dose from eating fish caught in the Great Miami River at the Fernald site outfall is discussed in Chapter Seven. 


\section{Monitoring for Nonradioactive Pollutants}

This section of the chapter looks at concentrations of nonradioactive pollutants discharged through the site's liquid effluent, to the Great Miami River, and to Paddlys Run. The site controls the discharge of nonradioactive pollutants in liquid effluent to meet the requirements of the site's National Pollutant Discharge Elimination System (NPDES) permit.

\section{NPDES Summary for 1993}

The NPDES permitting process for the site is under the jurisdiction of the State of Ohio to control the discharge of nonradioactive pollutants to Ohio waters. The permit specifies sampling locations, sampling and reporting schedules, discharge limits, and other restrictions on the site's effluents discharged to the Great Miami River and Paddys Run. Table 15 on pages A-20 through A-22 contains the NPDES compliance data for 1993 with a diagram of all monitoring locations in Figure 28. Fernald site personnel did not collect NPDES samples from Paddys Run since the SWRB did not overflow during 1993. Out of 4,(20) NPDES samples taken in 1993, only 11 were not in compliance (99.7\% compliance). Effective May 20, 1993, modifications to the NPDES permit were made including:

- $\mathrm{pH}$ monitoring was reduced to daily grab samples at internal monitoring locations;

- Sampling of sewage sludge was added;

- Fluoride, copper, nickel, and total chromium sampling were reduced to monthly monitoring at the sewage treatment plant;

- Cyanide, silver, and lead at Manhole-175 were eliminated;

- Chromium (+6) and pH at discharge 6(2) were eliminated; and

- All monitoring at discharges 604 and 60)6 (shown in Figure 28 on page 83) was eliminated.

By controlling the concentration of radionuclides in the effluent and by reducing the amount of stormwater runoff to Paddys Run, the site can lessen its impact on the various components of the liquid pathway. In particular, surlace water runoff can enter the aquifer and influence groundwater quality. The next chapter looks at the groundwater component of the liquid pathway. 


\section{Liquid Pathway:
Groundwater Monitoring \\ Liquid Pathway:
Groundwater Monitoring}
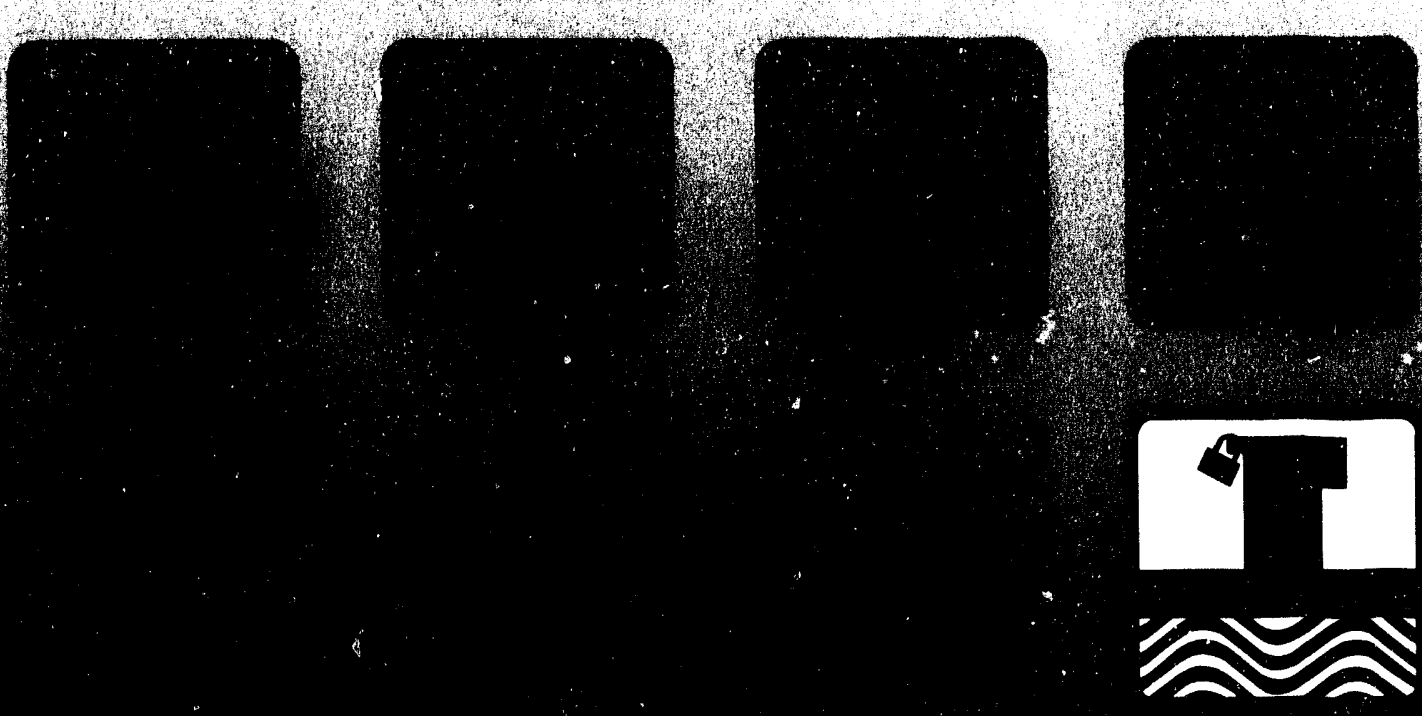


\section{Liquid Pathway: Groundwater Monitoring}

This chapter continues the discussion of the liquid pathway, as surface water runoff can leach through the soil and may contaminate the groundwater. The site carefully monitors the groundwater beneath and in the vicinity of the site to identify and track the movement of pollutants which may be present in the Great Miami Aquifer. Scientists can analyze the groundwater and soils sampled during drilling operations to learn much about the soil and its ability to restrict the movement of contaminants into the groundwater. This enables the site to better define the steps it should take to control present contamination and to prevent additional contamination from occurring.

\section{Results in Brief: 1993 Lquid Pathway: Groundwater}

Private Well Sampling - A total of 30 private wells were routinely sampled for total uranium in 1993. Three of these wrells had an average uranium concentration above the proposed USEPA standard of $13.5 \mathrm{pCi} / \mathrm{L}(20 \mathrm{ppb})$. Each of these wells is in an area of known groundwater contamination. These 36 wells were also sampled for several metals. As is common for an area with high natural concentrations of iron and manganese, such as the area surrounding the Fernald site, several private wells showed concentrations of these two metals above the USEPA Secondary Drinking Water Standards. Additionally, four wells showed concentrations of lead at or above the USEPA action level guideline.

Comprehensive Sampling - Of the 454 on- and offsite site-owned wells that were sampled for uranium, 127 wells showed detections above the proposed USEPA guideline of $13.5 \mathrm{pCi} / \mathrm{L}(20 \mathrm{ppb})$. All offsite locations were in the South Plume area. The Comprehensive Groundwater Monitoring Program also samples for 11 metals and 31 Volatile Organic Compounds which have applicable Primary Drinking Water Standards. Of these 42 constituents, 16 were detected above the primary standards in more than one well. Four other constituents showed single detections above their primary standards. 


\section{History of Groundwater Monitoring at the Site}

Several groundwater monitoring programs have evolved throughout the history of the site. The original three production wells drilled during the construction of the Feed Materials Production Center in 1951 were the first to be monitored. From 1959 to 1965 , the site installed eleven monitoring wells in the waste pit area to see if pit operations were affecting the groundwater. These waste pit and production area wells constituted the original Environmental Monitoring Groundwater Program.

In late 1981, the State of Ohio sampled three wells south of the site and found elevated levels of beta activity. It was found that this activity was due to potassium40, a naturally occurring radionuclide which was not present in site production materials. However, sampling also detected above-background concentrations of uranium in other wells near the site. This information was reported to the State in November 1981.

These findings prompted an expansion of groundwater monitoring in the area. Environmental Monitoring began sampling existing area wells in February 1982, and by 1984, the Fernald site officially established the Radiological Environmental Monitoring (Private Well) Program with the monthly sampling of 19 privately owned wells.

Around this same time, the site focused more attention on onsite groundwater contamination. The disposal of barium chloride in Waste Pit 4 from 1980 to 1983 led to the establishment of the RCRA Detection and Groundwater Quality Assessment Programs, separate from the existing environmental monitoring activities. Federal and state environmental regulations required the Fernald site to determine whether or not hazardous waste had entered the groundwater, and, if so, to identify the rate and extent of migration and the concentration of any hazardous waste in the groundwater. When the RCRA Detection Program confirmed that the groundwater had been impacted, the RCRA Groundwater Quality Assessment Program began in May 1988 and has since provided valuable information on the quality of groundwater beneath the waste pit area. (Analytical results of this sampling and assessment can be found in the RCRA Anmual Repont for 1993. 3i)

Also in May 1988, additional groundwater sampling was initiated as part of the Remedial Investigation and Feasibility Study (RI/FS). This CERCL.A-driven study investigates the nature and extent of potential environmental impacts from past and current operations at the site, with particular regard to the Great Miami Aquifer.

By late 1989. more than 2(0) wells were being sampled under the various programs. To eliminate duplication of efforts. all long-term groundwater monitoring responsihilities were shifted to the Environmental Monitoring group. In 1990, this group developed the Comprehensive Groundwater Monitoring Program to coordinate the sampling schedules of the original Environmental Monitoring Groundwater 
Program, and the RCRA Assessment Program. In December 1992, the administration of the Comprehensive Groundwater Monitoring Program was transitioned to OU5. This change was implemented to consolidate all groundwater monitoring and data interpretation under one group.

Today, as this Comprehensive Groundwater Monitoring Program monitors siteowned wells in accordance with the applicable regulations, the private well sampling program continues under Radiological Environmental Monitoring as a service to local residents and as an additional source of offsite groundwater information. Results are presented in this chapter as either private well results or as comprehensive sampling results.

\section{Monitoring for Radioactive Pollutants}

As part of the total liquid pathway, the movement of radioactive pollutants into and through the groundwater is of significant concern. This section discusses the results of private well sampling and of the Fernald site's comprehensive sampling program.

\section{Private Well Sampling for Uranium}

The Radiological Environmental Monitoring Program encompasses all sampling of privately owned wells. The program itself is divided into non-routine sampling and routine sampling.

At a property owner's request, any drinking water well near the site will be sampled for uranium to gain additional information about local groundwater quality, and the one-time sample results are reported to the well owner. If one of these "special request" samples shows a questionable or significant total uranium concentration, or if the well is believed to be representative of an area based on its location, the property owner has the option to participate in the routine sampling program. This program has grown from 19 wells in 1984 to 36 wells in 1993. Well locations are shown in Figure 36. The data from the routine sampling program are presented in Table 16 on page A-23. Figure 37 shows average uranium concentrations found in private wells from 1989 to 1993.

During 1993, the 36 offsite wells belonging to individuals and industries in the vicinity of the site were sampled monthly or quarterly and analyzed for total uranium. Average uranium concentrations in all but five wells were less than $2 \mathrm{pCi} / \mathrm{L}$ $(3 \mathrm{pph})$ and, therefore, less than $15 \%$ of the proposed USEPA standard. Only wells 12.13, and 15 exceeded this proposed standard in 1993. These concentrations can also be compared to national background levels for total uranium in groundwater of 0.07 to $6.8 \mathrm{pCi} / \mathrm{L}$ (0.1 to $10 \mathrm{ppb}$ ) or local background levels of 0.07 to $2.0 \mathrm{pCi} / \mathrm{L}(0.1$ to $3.0 \mathrm{ppb}$ ), which scientists have determined using a $95 \%$ confidence interval. ${ }^{31.32}$ 


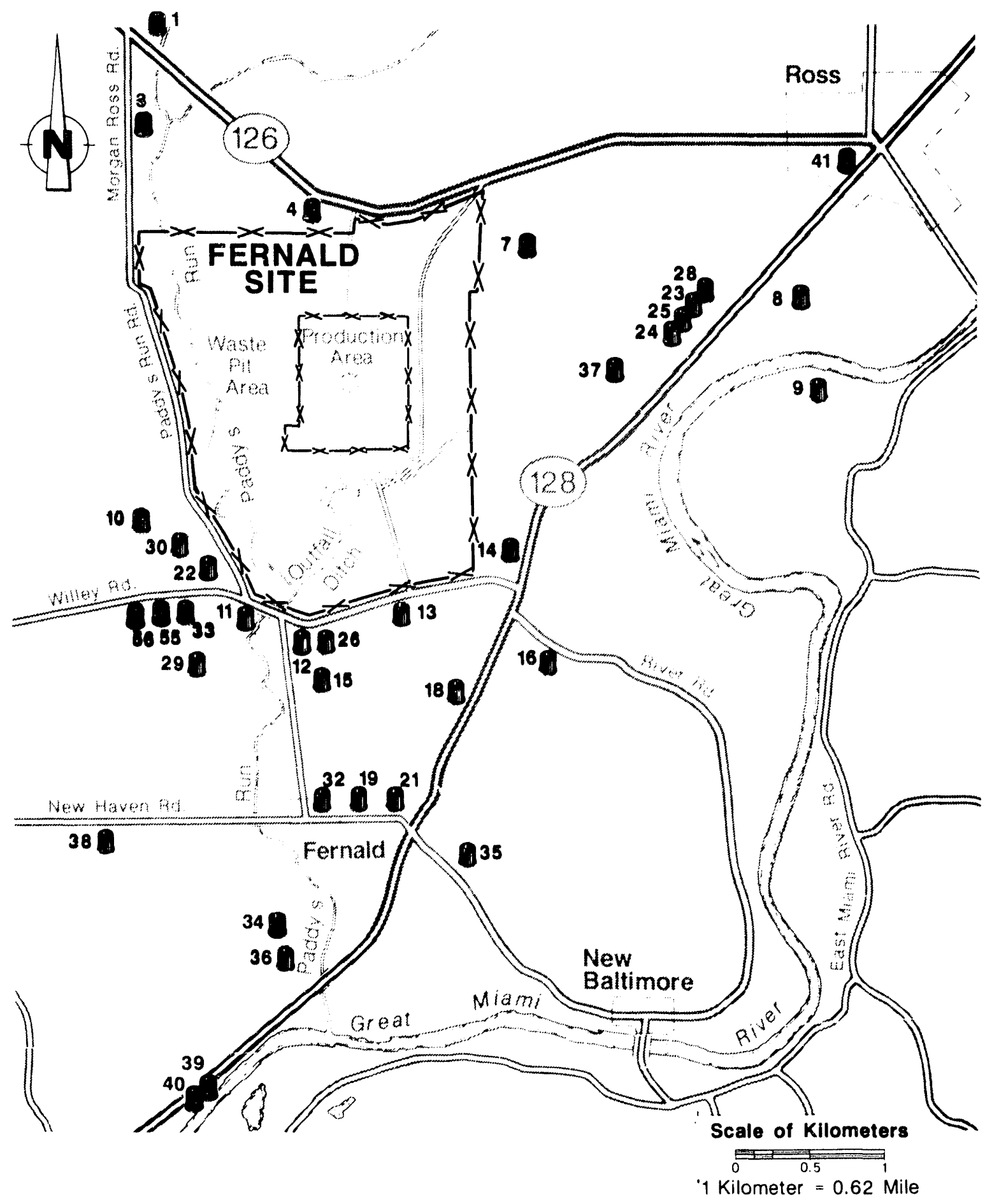

\section{LEGEND}

Sampling Location $\times-\times$ Plant Perimeter

$x-x-x$ Production Area Perimeter 

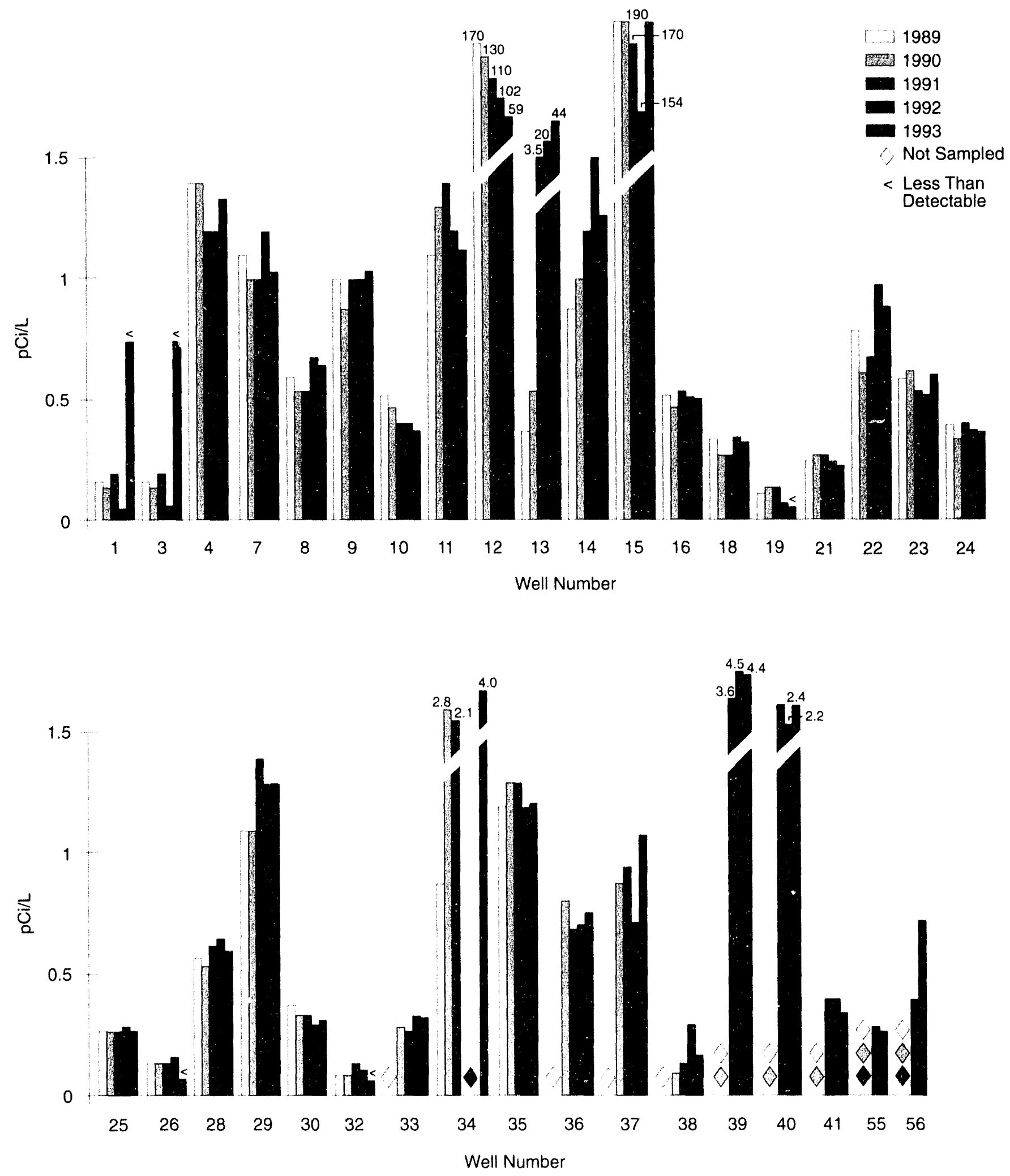


\section{PROPOSED USEPA STANDARD}

\section{For URANIUM IN DRINKING WATER}

In addition to comparing results against background levels for substances in the environment, environmental monitoring re sults are often compared to standards or guidelines. These standards set concentration limits for specific substances in a medlum. Standards and guidelines are always set lower than the lowest concentration known to cause iliness or injury to humans or the environment.

USEPA is responsible for setting standards for substances in drinking water throughout the United States; National Primary Drinking Water Standards are enforceable by federal law. However, in the absence of a USEPA standard for a particular substance, guidelines are set by other agencies such as DOE and the Nuclear Regulatory Commission; these guidelines, however, are only applicable to DOE- or NRC-governed sites.

Through 1990, the only reference for uranium in drinking wa ter was a DOE guideline of $20 \mathrm{pC} / \mathrm{L}$ or 30 parts per billion $(\mathrm{ppb})$. Past site reports have used this reference for comparison. However, in 1991, USEPA proposed a standard for uranium in drinking water of $13.5 \mathrm{pCi} / \mathrm{L}$ or $20 \mathrm{ppb}$. As of December 1993, this standard had not yet been approved. This 1993 report will continue to use this proposed USEPA standard for comparison with well monitoring results, as it is the more stringent of the two.
The uranium concentration at Well 13 has been slowly increasing since 1989. In June 1992. an ion exchange system was installed at this location. This system is designed to remove the uranium from the well water by filtering the water. Results from the water filtered through the ion exchange system indicate that the uranium is removed and the uranium concentration in the treated water is within the background range for this area. Well 13 is located just south of the site, in an area of known groundwater contamination, and continues to be a point of monitoring.

The uranium-contaminated water in this area, known as the South Plume, will be pumped from the aquiler as part of the South Groundwater Contamination Plume Removal Action. The plume itself is discussed later in this chapter.

\section{Comprehensive Sampling for Uranium}

The Comprehensive Groundwater Monitoring Program encompasses all sampling of site-owned monitoring wells. Groundwater monitoring personnel do not monitor all wells each quarter, nor do they monitor all wells for the same constituents. As discussed earlier, site personnel sample as necessary to provide each of the groundwater monitoring subprograms with a complete database for reporting purposes. However, when taken together, as done here, the comprehensive sampling results present a rather detailed and complete description of groundwater under and around the site.

The movement of uranium in the groundwater has been a key factor in determining the sources of contamination in the area. In 1993, the Groundwater Monitoring Program received results from $2 .(0) 3$ analyses for total uranium from samples at 454 on- and offsite locations. As compared to previous years' monitoring activities, there were several :more detections of total uranium found in 1993. This greater number of detections is due to an increase in monitoring activities that were required in 1993 for the final OU5 Remedial Investigation, and it is not an indication of greater contamination in the area. 
Of these $2.0(0) 3$ uranium analyses, the highest concentration was $91,120 \mathrm{pCi} / \mathrm{L}$ $(136,(0) \mathrm{ppb})$, well above the proposed USEPA standard of $13.5 \mathrm{pCi} / \mathrm{L}$ (20 $\mathrm{ppb}$ ). This sample was drawn from Well 1.324 in the glacial overburden directly beneath the production areat. Most above-guideline detections at the other sampled wells were below $6,757 \mathrm{pCi} / \mathrm{L},(10,(0)() \mathrm{pph})$. More than 240 uranium concentrations above the proposed USEPA drinking water guideline were found at 126 other on- and offsite locations. (All of fsite locations were in the South Plume area, currently being addressed by a RI/FS removal action.) All of the above-guideline sample concentrations and their relative locations are listed in Table 17 on pages A-24 through A-27.

Figure 38: Well Diagram*

\section{Fernald Site Groundwater Weus}

Figure 38 depicts a typical well at the Fernald site. The depth of a Fernald site well and the waterbearing zone into which it extends are denoted by the first digit of the well number (see Figure 39). Wells extending into the perched groundwater within the till are denoted as 1000-series wells. Wells extending into the upper portion of the sand and gravel aquifer are denoted as 2000series wells. The 3000-series wells are placed within the middle portion of the sand and gravel aquifer, and the 4000-series wells are installed in the sand and gravel aquifer beneath a layer of "blue clay." Sometimes a group of two or more wells of different depths are drilled at the same location to sample different water-bearing zones within the groundwater; these groups are called cluster wells.
- Not Drawn to Scale

This diagram depicts the construction of a typical well used for sampling groundwater. These wells are located both on and off the Fernald site. They range from $11-76$ meters $(35-250$ feet) deep.
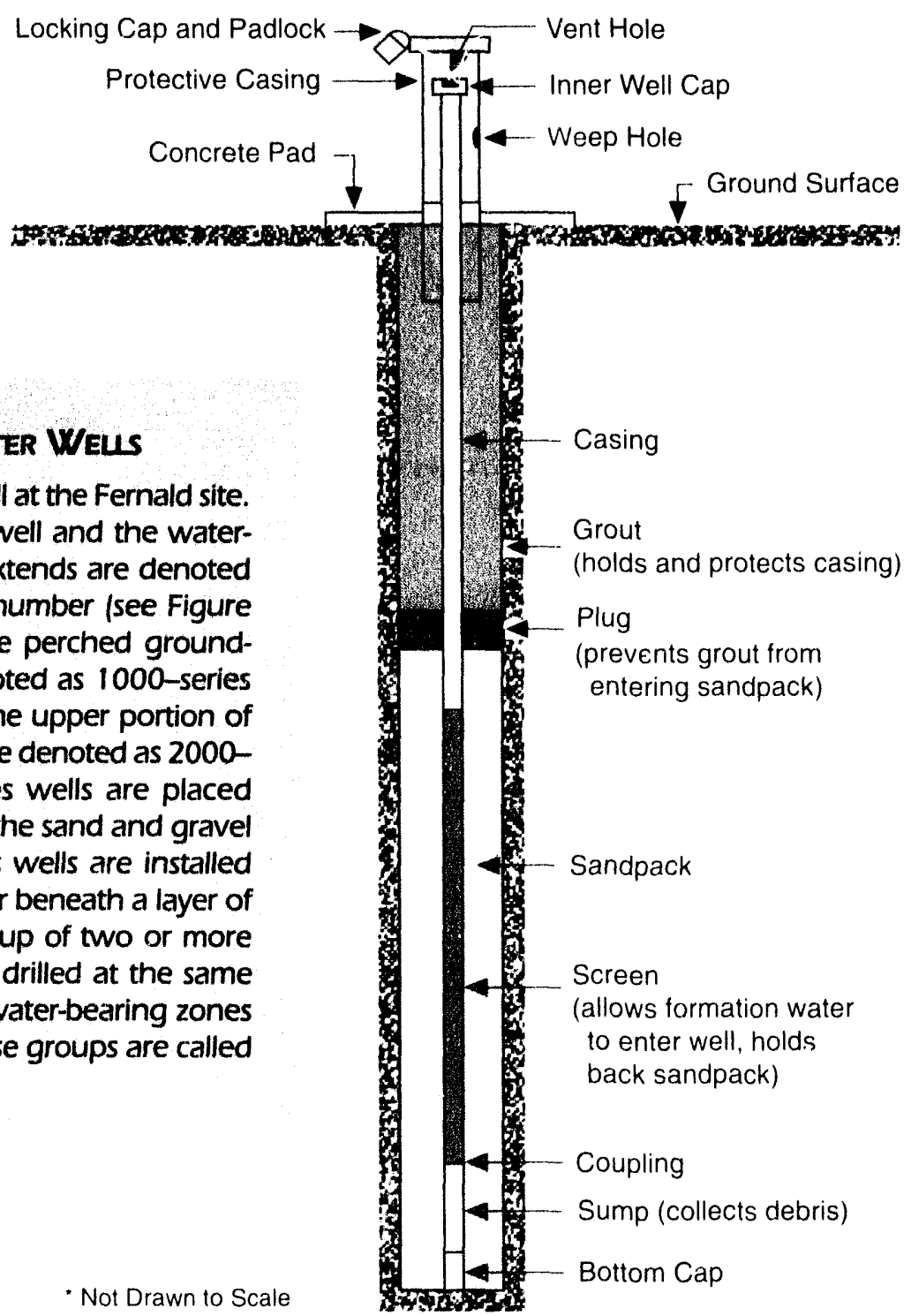


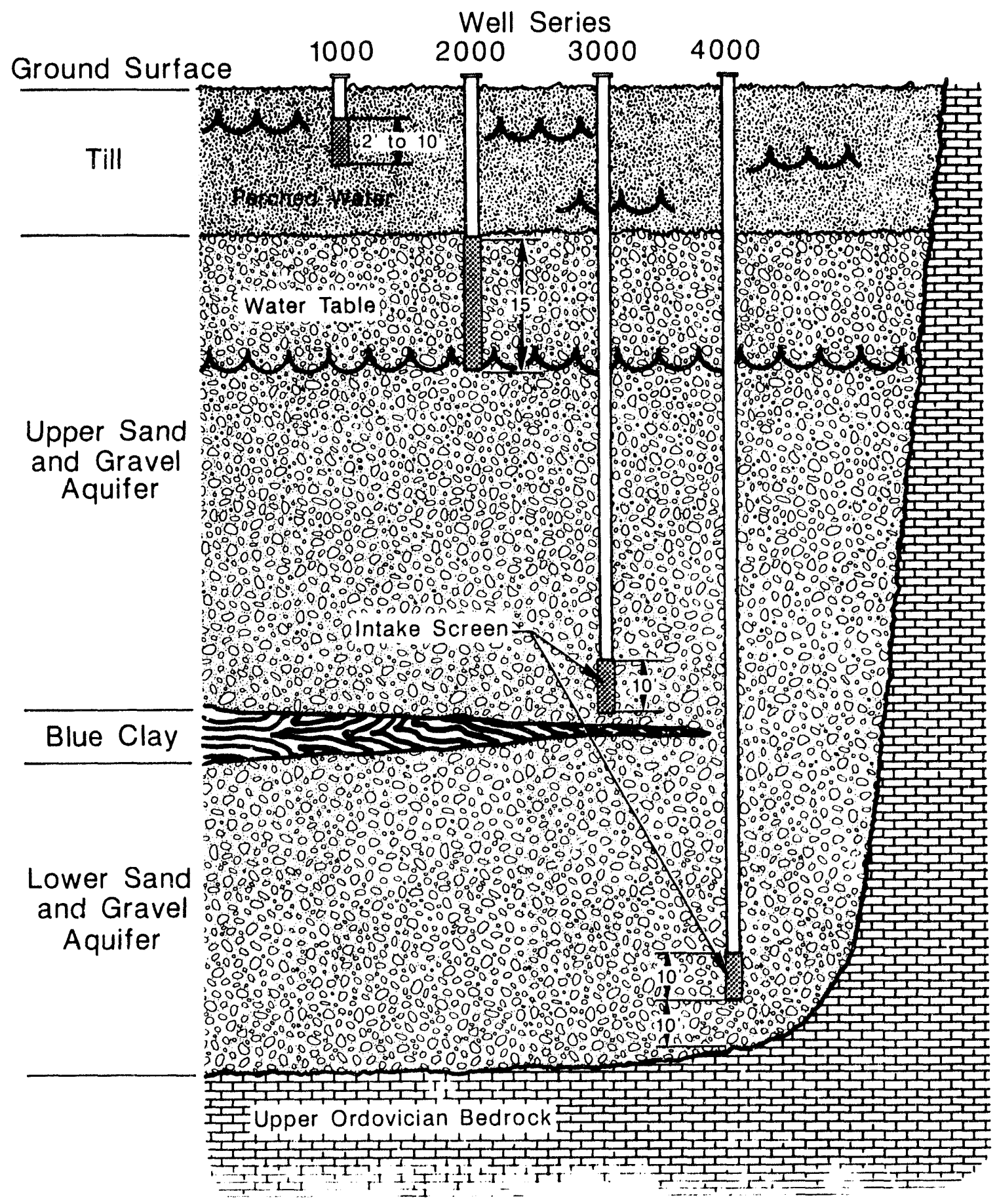

Metric Conversion

1 Foot $=0.3048$ Meters 


\section{Comprehensive Groundwater Monitoring for Other Radionuclides}

The Comprehensive Groundwater Monitoring Program also samples for radium-226. radium-228, strontium-90, technetium-99, and thorium-232. Gross alpha activity, gross beta activity, cesium, plutonium, ruthenium, and neptunium in the groundwater are also monitored as indicators of radionuclide contamination. Results from 1991 and 1992 monitoring for these radionuclides have been invalidated and cannot be reported with any assurance of data quality.

The Comprehensive Groundwater Monitoring Program sampled for these radionuclides again in 1993. These data are not available at this time, but they will be included in the Operable Unit 5 Remedial Investigation report and in the 1994 Site Environmental Report.

\section{South Groundwater Contamination Plume}

Groundwater monitoring results over the past several years have led to the identification of the South Groundwater Contamination Plume, an area immediately south of

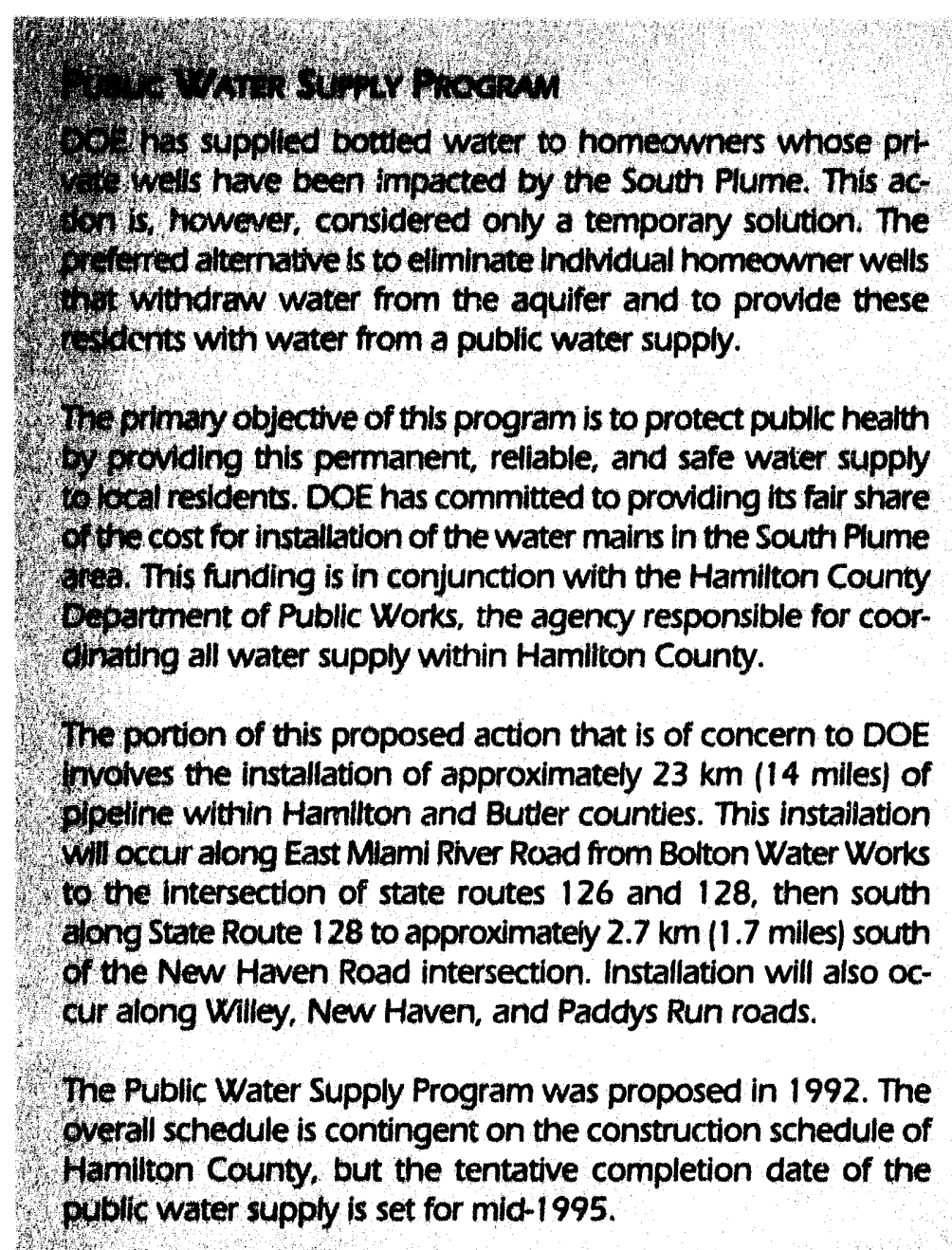

the site with known levels of uranium contamination. Containination from the site flows with the groundwater, generally to the east and south, toward the Great Miami River.

Because groundwater in the Fernald area travels very slowly as compared to surface water, some areas may not see the effects of the contamination for years. Also, since the contamination moves in about the same direction as the greundwater, environmental monitoring personnel can track the movement of this plume by monitoring the movement of the groundwater. Figure 40 shows the South Groundwater Contamination Plume as it appeared at the end of 1993.

The South Groundwater Contamination Plume Removal Action was initiated to restrict further southward movement of the plume, to limit access and exposure to contaminated groundwater, and to protect the groundwater environment. 


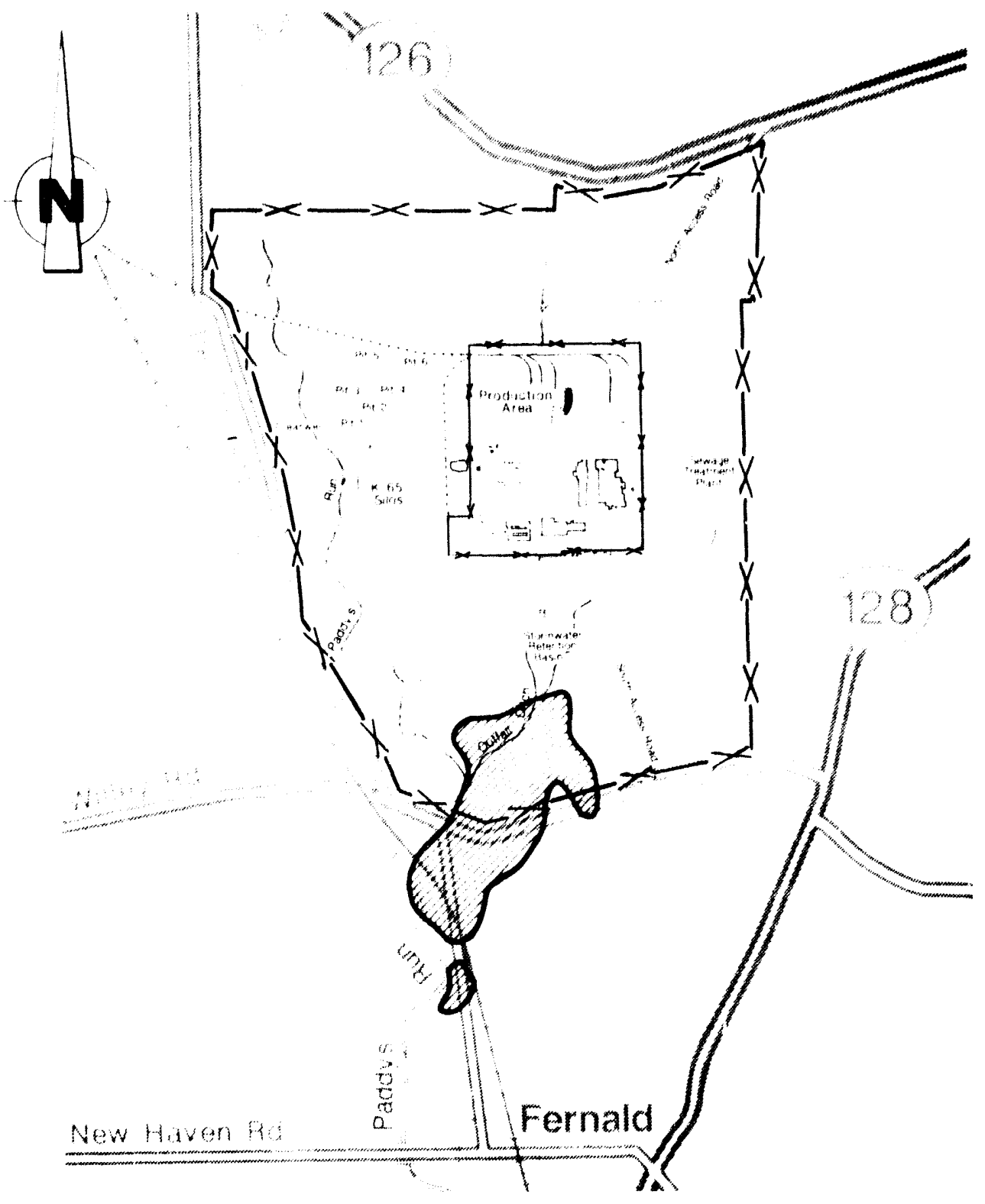

Scale of Kilometers

${ }_{0}^{1.0}{\text { Kilometer }=0.62 \mathrm{Mile}^{2.0}}^{2.0}$

\section{LEGEND}

Exceeding $13.5 \mathrm{pCi} / \mathrm{L}(20 \mathrm{ppb})$ 


\section{Monitoring for Nonradioactive Pollutants}

Protection of the Great Miami Aquifer also includes monitoring for a number of nonradioactive pollutants and general water quality indicators. Site technicians generally sample for those constituents listed in the National Primary and Secondary Drinking Water Standards. Primary standards apply to those substances that pose definite health threats if present beyond the regulatted concentrations: secondary standards control contaminants that primarily affecl the aesthetic gualitien of drinking watter and are not federally enforceable. "In addition to these USEPA-listed constituents, the RCRA wells within the Comprehensive Groundwater Monitoring Program are sampled for many RCRA-listed constituents.

\section{Private Well Sampling for Metals}

The 1993 samples from the private wells were analyzed for the 16 metals listed in Table 18 on pages A-28 through A-30. Of these 16 metals. no DOE or USEPA standards have been established for calcium, magnesium, nickel. potassium, or sodium, but they continue to be monitored for comparison purposes. Although concentrations of iron and manganese were higher than the secondary drinking water guidelines in a number of wells, high concentrations of those natural elements are typical for groundwater in this area. ${ }^{5}$. " As specified by USEPA, lead hats an action level of $0.015 \mathrm{mg} / \mathrm{L}$. Four wells showed lead concentrations above this level. All other metal concentrations were well within the appropriate guidelines.

\section{Comprehensive Sampling for Hazardous Substances}

Various groundwater sampling programs monitor for nonradioactive constituents in the groundwater to identify areas that might have harmful chemical concentrations as a result of past and present site activities. All site wells sampled are analyzed for metals, volatile organic compounds (VOCs), and water quality indicattors listed in the National Primary and Secondary Drinking Water Standards. This section focuses on the incidences in which these constituents occur above the applicable standards. Those wells with detections above the primary standards and the proposed USEPA guideline for uranium are mapped in figures 41 through 4.

\section{Detections above Primary Standards}

The site analyzes for 11 metals and 31 VOCs which have applicable Primary Drinking Water Standards. Of those 42 metals and VOCs, the constituents that had detections above their respective Primary Drinking Water Standard Maximum Contaminant Levels ( $\mathrm{MCL}$ ) are listed on the next page and in Table 19 on pages A-31 through A-36. 
Metals

- Antimony

- Arsenic

- Barium

- Beryllium

- Cadmium

- Chromium
- Cyanide

- Mercury

- Nickel

- Selenium

- Thallium

\section{Volatile Organic Compounds}

- Benzene

- Carbon tetrachloride

- 1.2-Dichloroethane

- 1,2-Dichloropropane

- Ethylbenzene
- Toluene

- 1,1,1-Trichloroethane

- 1,1,2-Trichloroethane

- Vinyl chloride

Toluene, 1,1,2-trichloroethane, 1,2-dichloropropane, and ethylbenzene, had only one detection each above their respective standards. The remaining sixteen constituents had more than one detection above their standards in 1993. These detections and the areas in which they were found are discussed below.

Antimony was detected above the $0.006 \mathrm{mg} / \mathrm{L}$ MCL in 17 wells during 1993. These wells were located primarily in the production area and the waste pit area. Five detections were south or southwest of the Stormwater Retention Basin, one in the northwest corner of the site, and one in the South Plume. There was also one detection offsite, just northwest of the site property. These detections above the $\mathrm{MCL}$ ranged from $0.0(0) 61$ to $0.135 \mathrm{mg} / \mathrm{L}$.

Arsenic wals detected above the $0.050 \mathrm{mg} / \mathrm{L} \mathrm{MCL}$ at seven wells. Three detections were in the waste pit area, six were in the northwest section of the site, two were near Paddys Run just south of the silos, and two were in the Paddys Run Road Site area. These detections above the $\mathrm{MCL}$ ranged from 0.0711 to $0.313 \mathrm{mg} / \mathrm{L}$.

Barium has a $\mathrm{MCL}$ of $2 .(10) \mathrm{mg} / \mathrm{L}$. It was detected at two wells, and the detections were 2.26 and $3.35 \mathrm{mg} / \mathrm{L}$. One well was located in the production area, and one was just north of the production area.

Fourteen wells had detections of beryllium above the $\mathrm{MCL}$ of $(0.0) 4 \mathrm{mg} / \mathrm{L}$. These detections ranged from $0 .(0) 4$ (o $0.131 \mathrm{mg} / \mathrm{L}$. Most of these wells are in the production and waste pit areas. Other detections were found south of the silo area, southwest of the Stormwater Retention Basin, and one each in both the northwest and northeast sections of the site. 


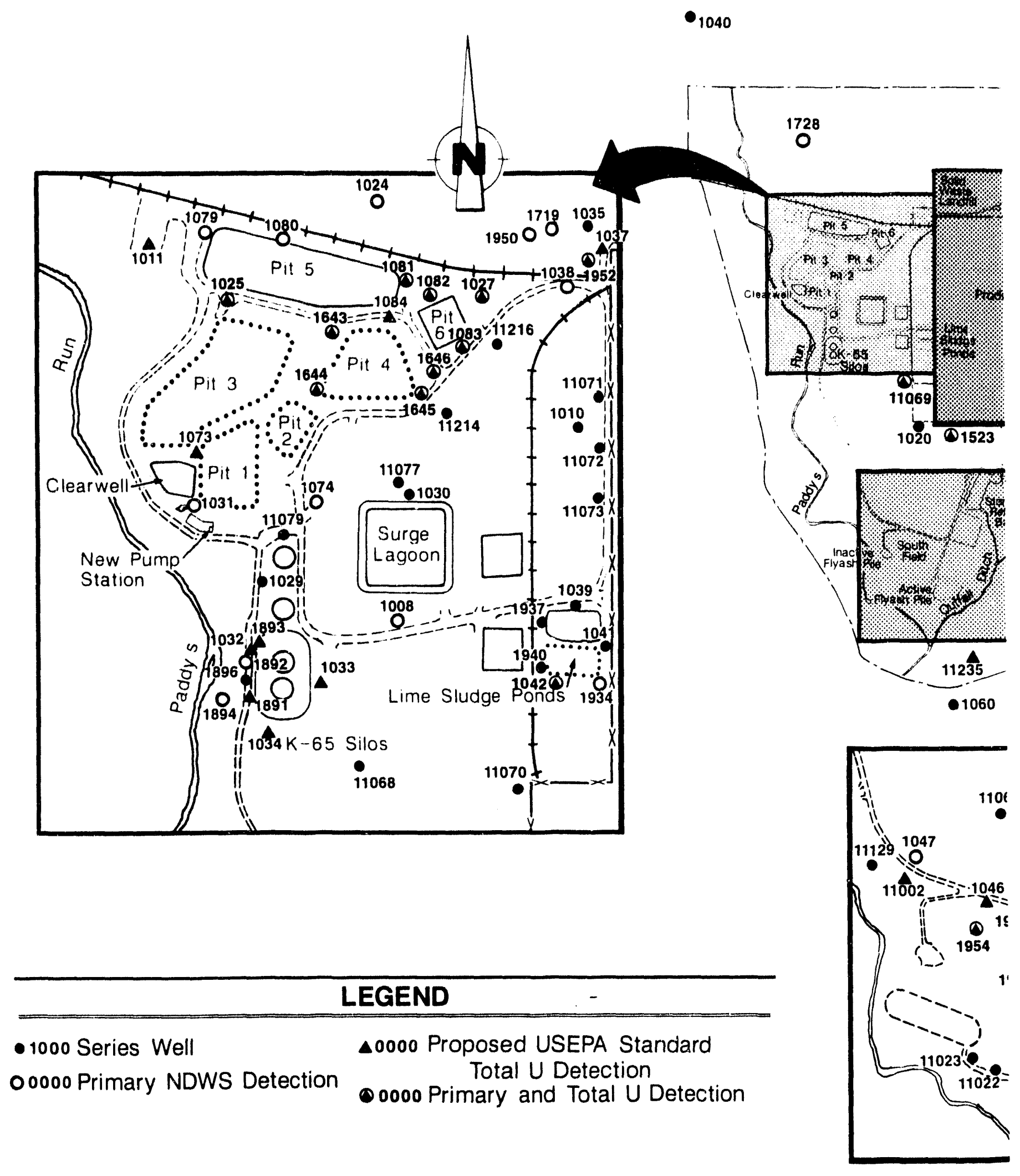




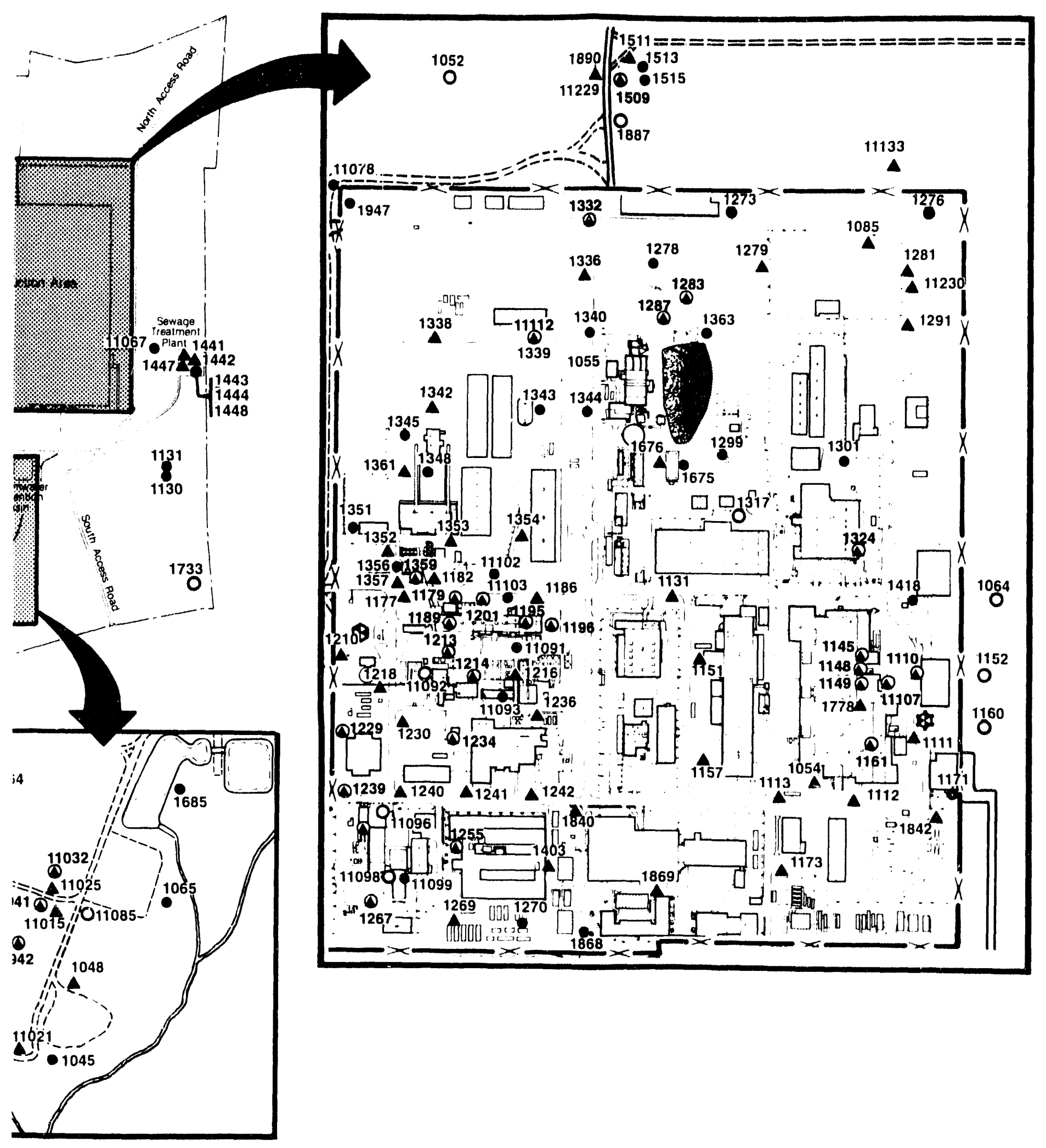




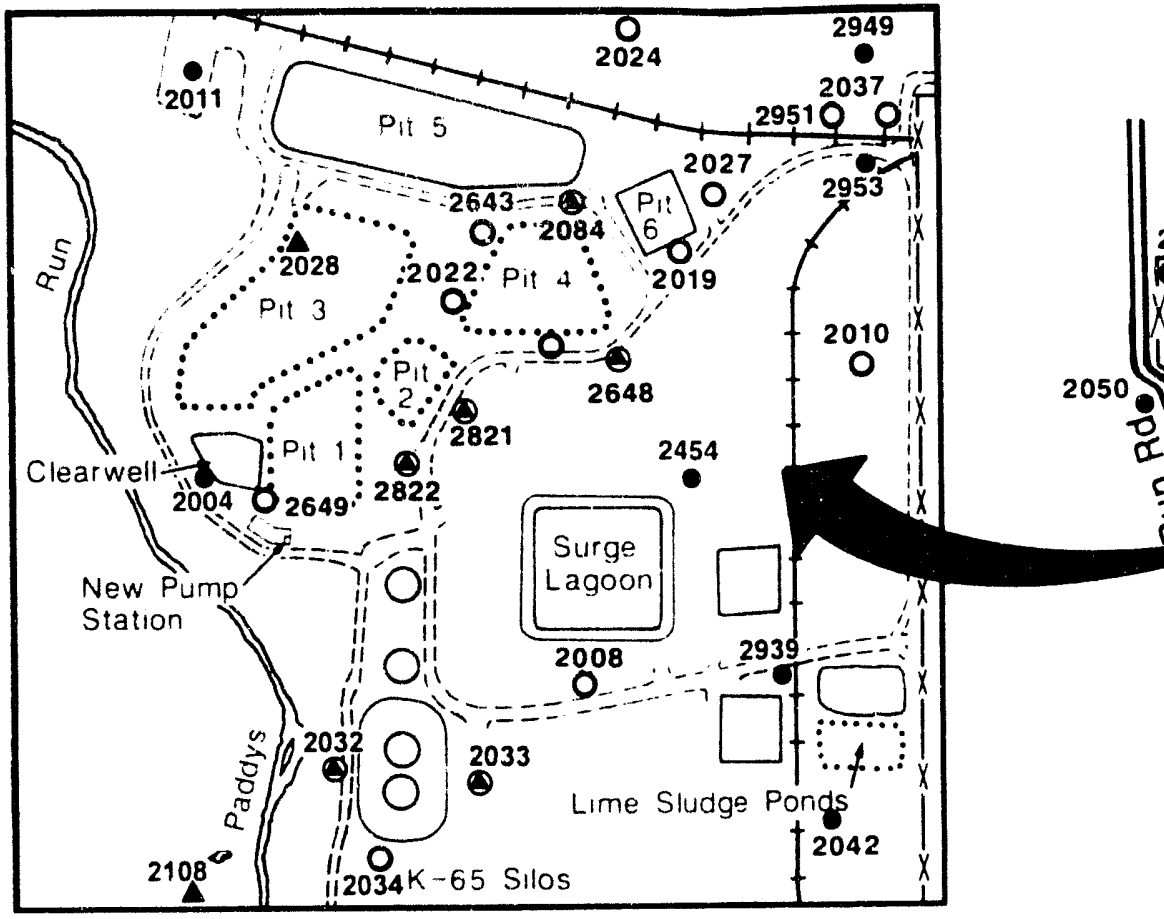

Rd.

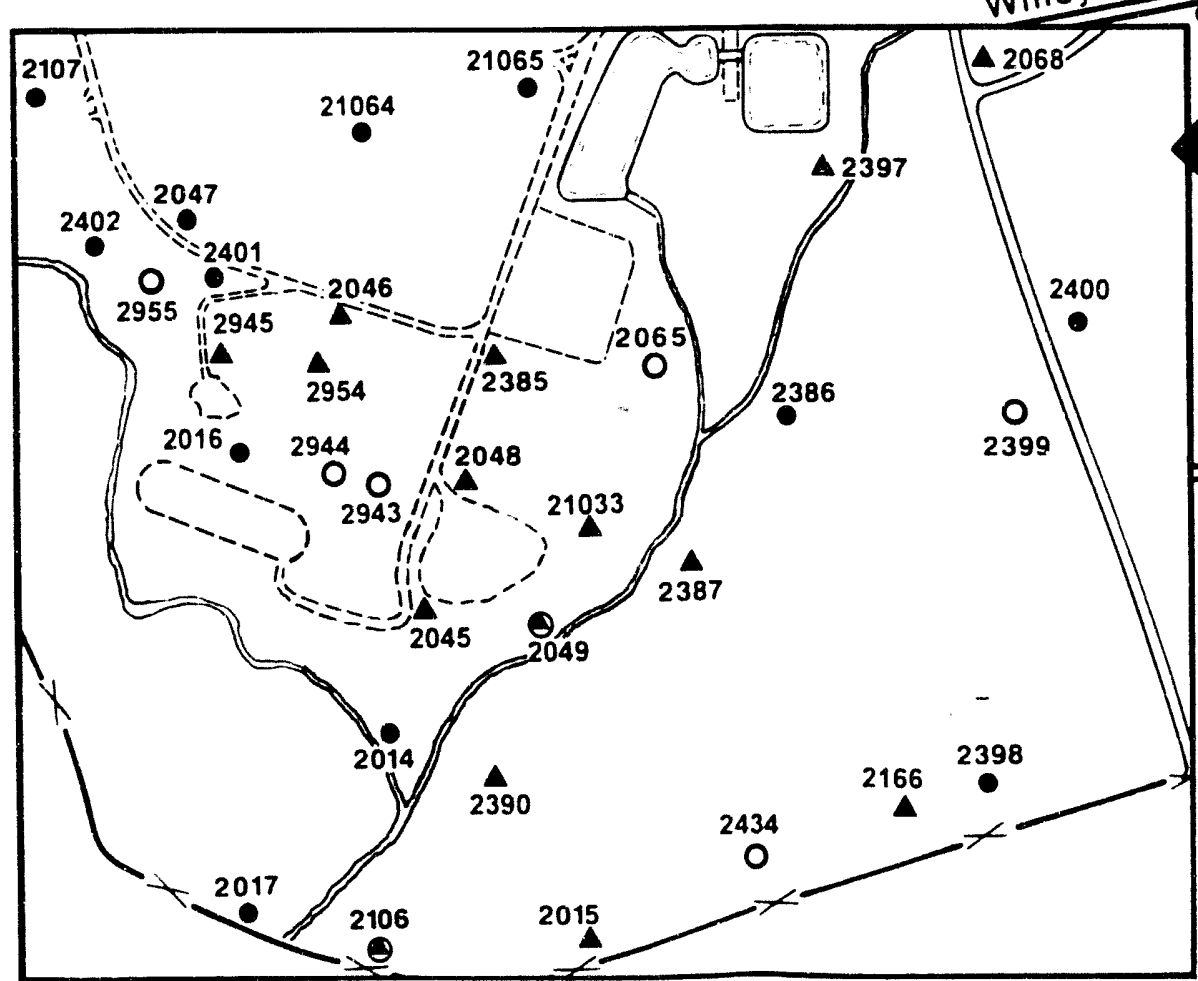

126
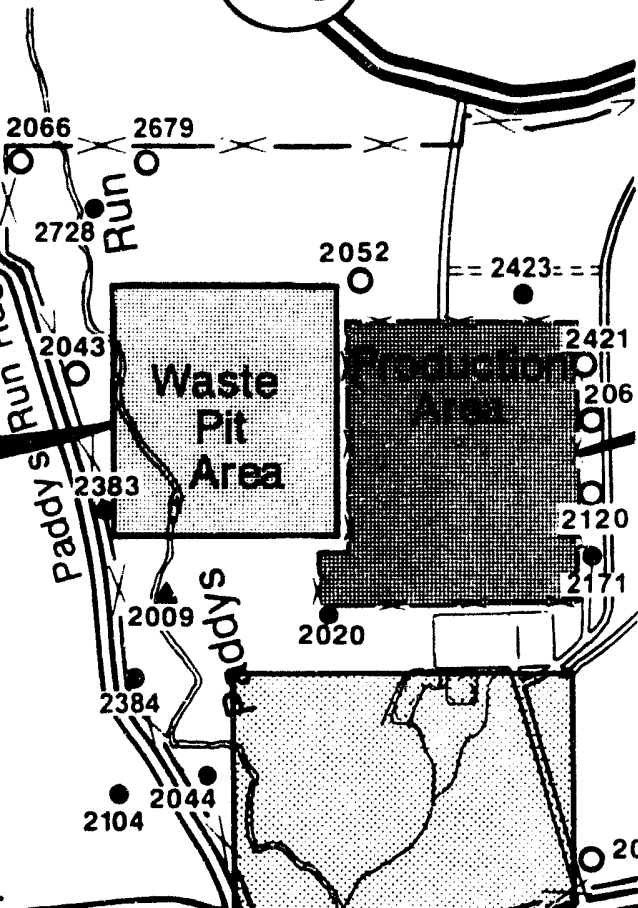

$\longdiv { 2 0 9 6 }$

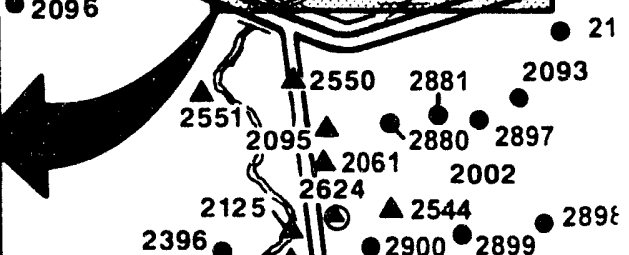

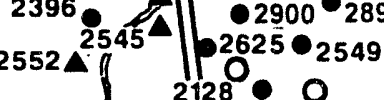

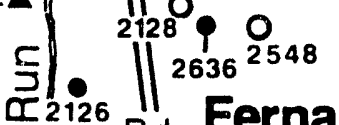

New Haven ${ }_{1}^{2126}$ Rd. Fernald

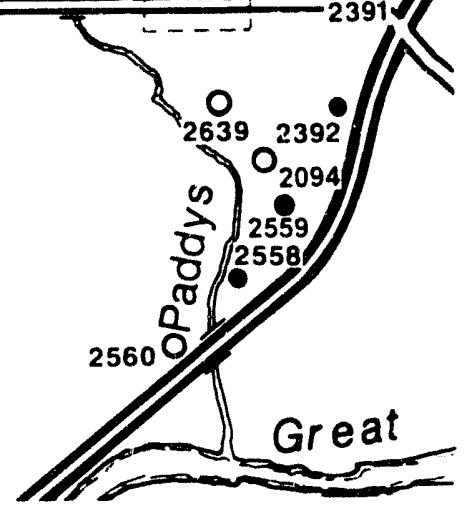



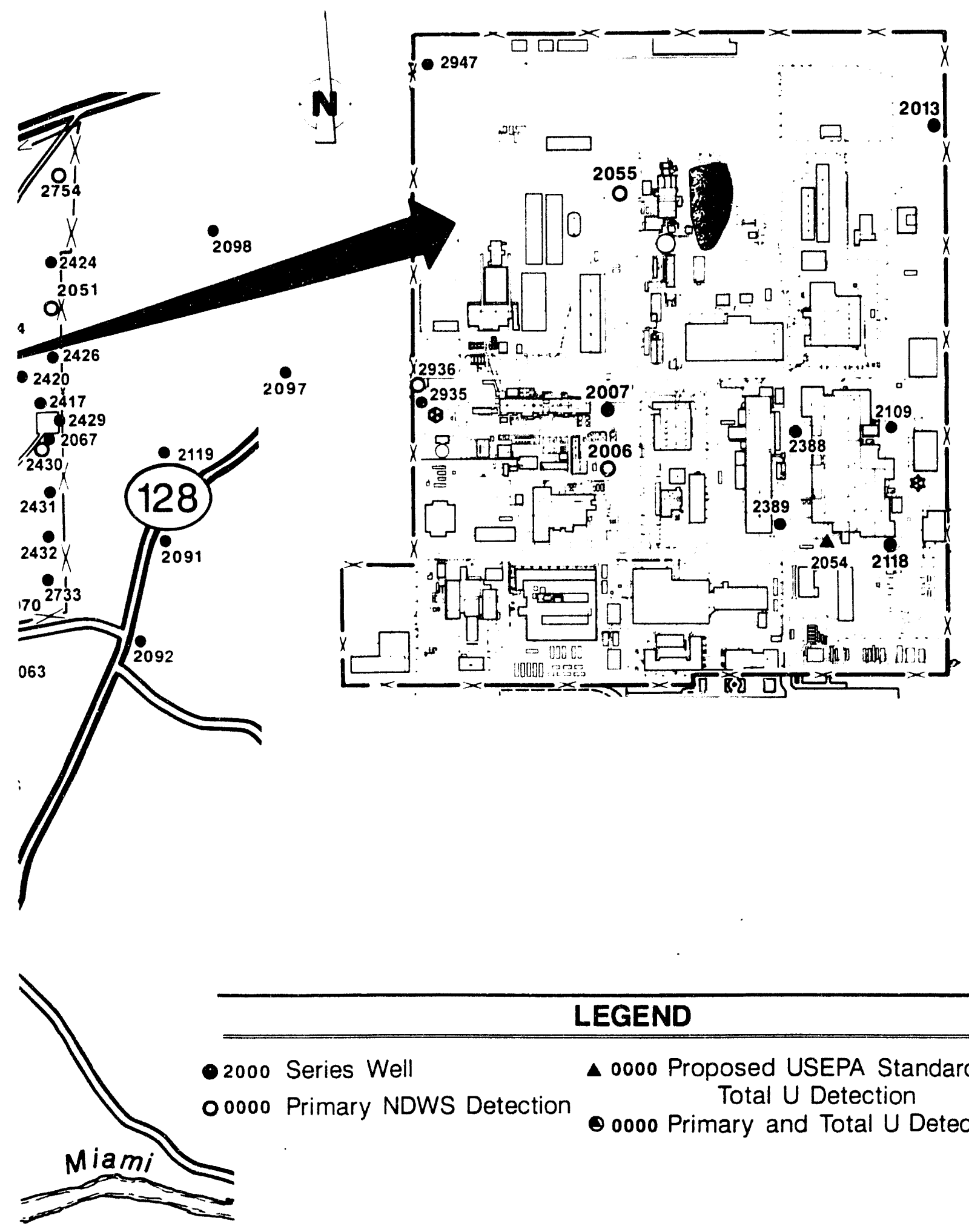

\section{LEGEND}

\ 0000 Proposed USEPA Standard

Total U Detection
$\Theta 0000$ Primary and Total U Detection 

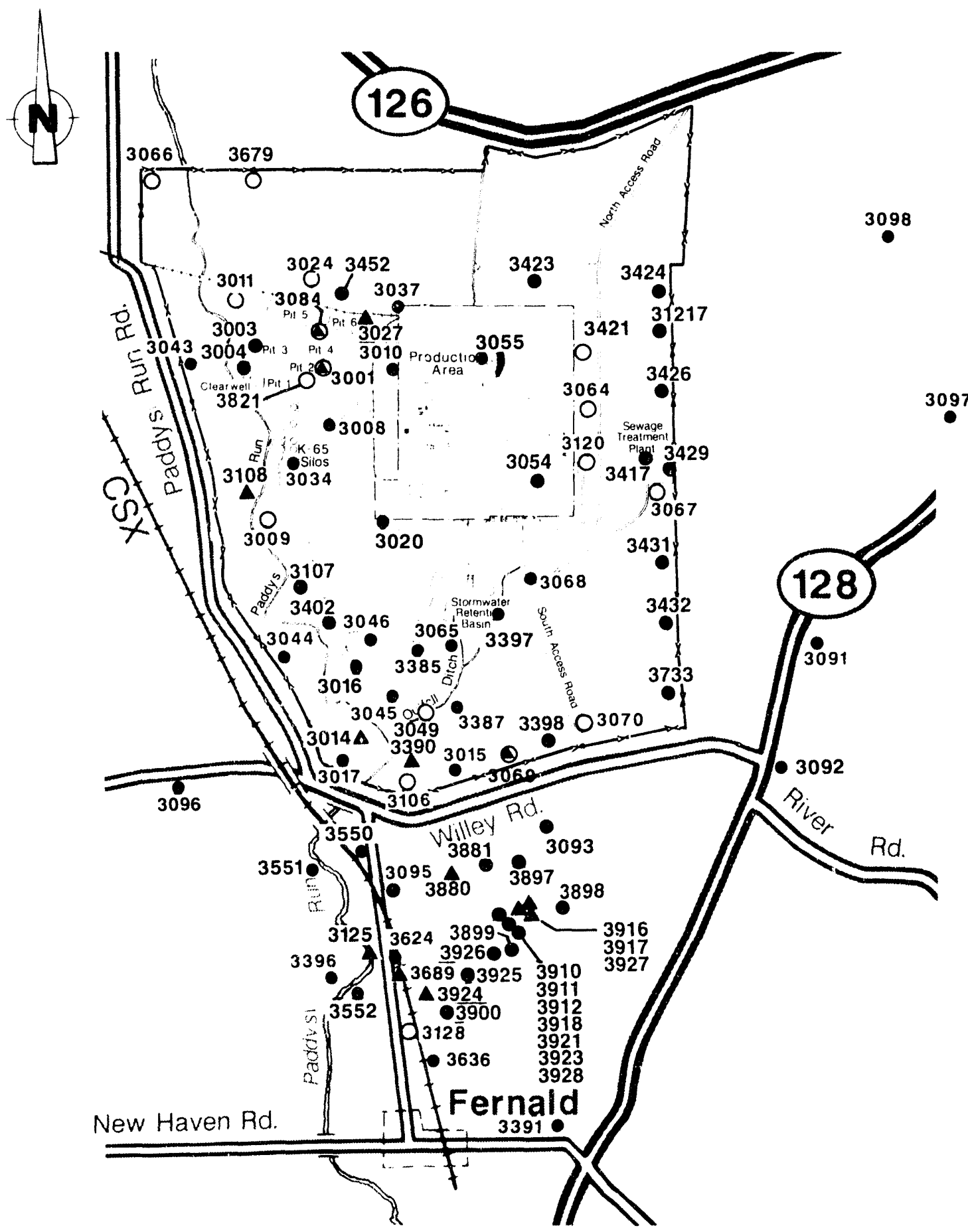

\section{LEGEND}

- 3000 Series Well

00000 Primary NDWS Detection

$\triangle 0000$ Proposed USEPA Standard

Total U Detection

$\$ 0000$ Primary and Total U Detection 

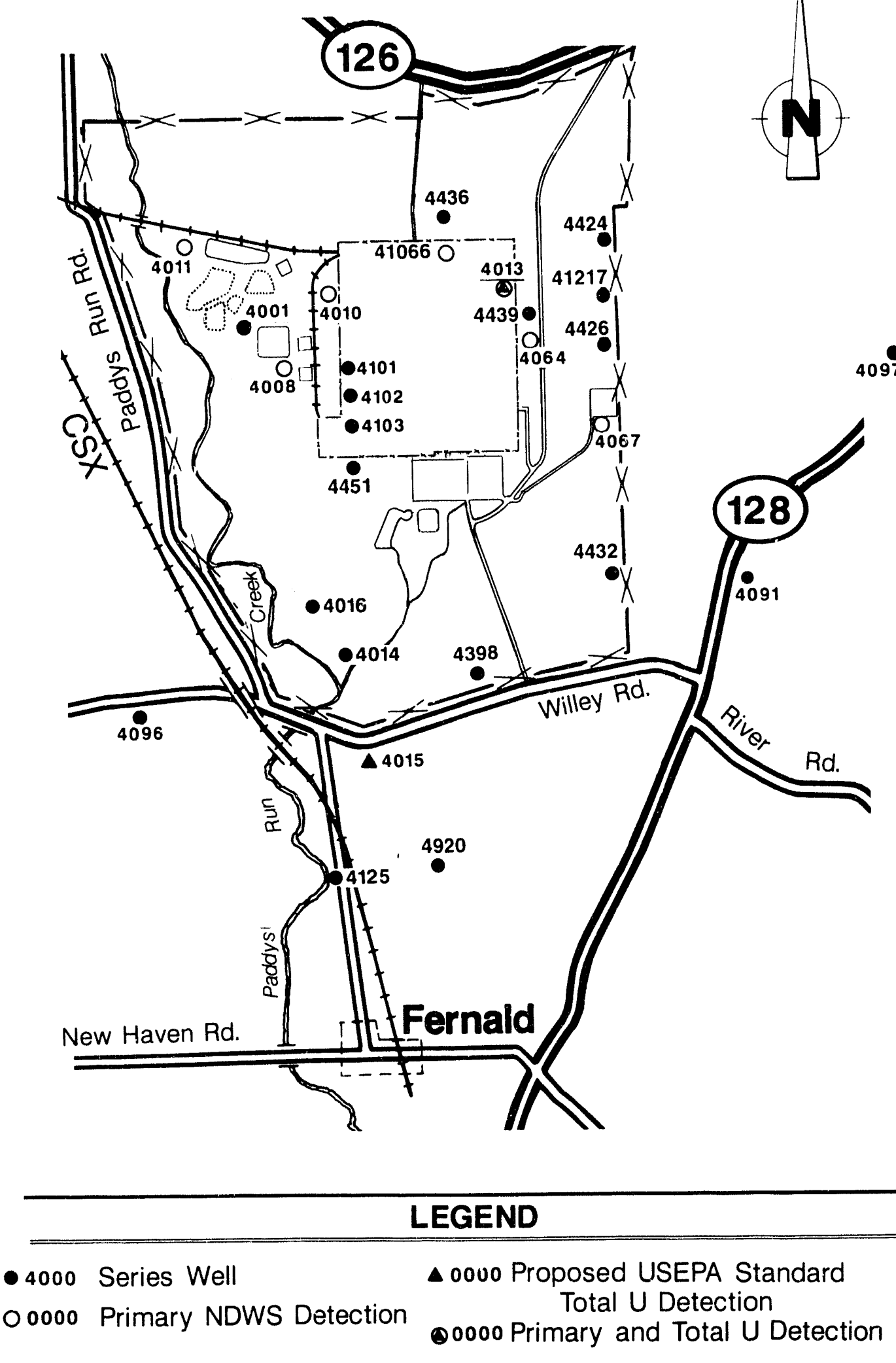
Cadmium had detections at 35 wells above the $\mathrm{MCL}$ of $0.005 \mathrm{mg} / \mathrm{L}$. These detections fell in the range of 0.005 to $0.165 \mathrm{mg} / \mathrm{L}$. Primarily these detections were in the production area with a few in the waste pit and silo areas. Several detections also showed at wells northeast, east, and southeast of the production area, and south of the Stormwater Retention Basin. Three detections were shown in the northeast corner of the site.

Twenty-five wells showed detections of chromium above the MCL of $0.100 \mathrm{mg} / \mathrm{L}$. The detections ranged from 0.105 to $7.710 \mathrm{mg} / \mathrm{L}$, and were mainly in or near the production area. In addition, there were detections in the South Plume, southwest of the Stormwater Retention Basin, near the silos, and one in the northwest section of the site.

Cyanide had detections at one well of 0.354 and $0.360 \mathrm{mg} / \mathrm{L}$. These detections were at a well near Paddys Run, south of the silos. The MCL for cyanide is $0.200 \mathrm{mg} / \mathrm{L}$.

Two detections of mercury were found above the MCL of $0.002 \mathrm{mg} / \mathrm{L}$. These came from a single well and were $0.0(077$ and $0.0139 \mathrm{mg} / \mathrm{L}$. This well was near Paddys Run, south of the silo area.

Nickel has a MCL of $1.00 \mathrm{mg} / \mathrm{L}$. It was detected at 29 wells, and the detections ranged from $1 .(1)$ to $3.930 \mathrm{mg} / \mathrm{L}$. Most of these were located in the production area and waste pit area. However, detections were also shown southwest of the stormwater retention basins, north and northeast of the production area, in the South Plume, at a location near State Route 128, and at a location in the northwest section of the site.

Two wells showed detections of selenium above the MCL of $0.050 \mathrm{mg} / \mathrm{L}$. These detections were in the range of 0.0563 to $0.214 \mathrm{mg} / \mathrm{L}$. The wells were located northeast of the production area and south of the silos near Paddys Run.

There were also detections of thallium that exceeded the MCL of $(0.002 \mathrm{mg} / \mathrm{L}$. They ranged from 0.002 to $0.094 \mathrm{mg} / \mathrm{L}$ and came from a total of four wells. The locations of these wells included the waste pit area and the area near the silos.

Benzene was detected at two wells above the MCL of $0.005 \mathrm{mg} / \mathrm{L}$. These detections were 0.005 and $0.011 \mathrm{mg} / \mathrm{L}$, and were from a well in the production area and a well south of New Haven Road.

Two detections of carbon tetrachloride were 0.005 and $0.021 \mathrm{mg} / \mathrm{L}$, both of which exceed the MCL of $0.005 \mathrm{mg} / \mathrm{L}$. These detections were in the production area.

Four wells showed detections of 1.2-dichloroethane to exceed the MCL of 0.0)(5) $\mathrm{mg} / \mathrm{L}$. These detections ranged from 0.011 to $0.072 \mathrm{mg} / \mathrm{L}$. and came from wells located in the production area and near the Fire Training Facility.

The MCL for 1,1,1-trichloroethane is 0.20() $\mathrm{mg} / \mathrm{L}$. This was exceeded by detections at four wells in a range of $(0.2(0)$ to 5.90() $\mathrm{mg} / \mathrm{L}$. These detections came from the production area and a well from the Fire Training Facility area. 
Finally, vinyl chloride, a volatile organic compound used in a variety of processes involving solvents, paints, and gasoline, was found in two wells with detections above the standard of $0.002 \mathrm{mg} / \mathrm{L} .{ }^{34}$ These detections were 0.031 and $0.120 \mathrm{mg} / \mathrm{L}$. The wells are located in the production area.

\section{Detections above Secondary Standards}

Several constituents were detected above their secondary standards in 1993. However, it should be noted that many of these secondary constituents are niturally occurring. and their presence does not pose a threat to human health or to the environment except at considerably higher concentrations. ${ }^{35}$

Iron and manganese are two particularly noteworthy examples of such naturally occurring elements. Both are commonly found at high levels in southwest Ohio. Iron was detected above its secondary standard at 525 on- and offsite wells, and manganese was detected above its standard at 622 wells.

One detection of copper at 1.03() $\mathrm{mg} / \mathrm{L}$ exceeded the standard of 1.00() $\mathrm{mg} / \mathrm{L}$. This detection was from the Fire Training Facility.

Fifty-one wells had detections of lead in the range of (0.015 to $0.262 \mathrm{mg} / \mathrm{L}$. all of which exceeded its standard of (0.0)15 $\mathrm{mg} / \mathrm{L}$. These detections were primarily from the production and waste pit areas. Detections were also found south and southwest of the Stormwater Retention Basin, in the South Plume, just east of the production area, near the sewage treatment plant. at the northeast corner of the site, in the northwest section of the site, at the south access road, and just northwest of the site boundary.

\section{RCRA Groundwater Monitoring at the Fernald Site}

The disposal of barium chloride in Waste Pit 4 from 1980) to 1983 necessitated groundwater monitoring under RCRA at the Fernald site. In response, a Detection Monitoring Program was initiated at Waste Pit 4 in August 1985. The program included monitoring of 41 wells upgradient and downgradient of Waste Pit 4 for general water quality, drinking water suitability, and indicaltor parameters.

Based on the statistical comparisons that were completed as part of the Detection Monitoring Program, USEPA and OEPA were notified in November 1987 that Waste Pit 4 may be affecting ground water quality in the vicinity of the pit. At that time, the RCRA Detection Monitoring Program was changed to the RCRA Assessment Monitoring Program, and the RCRA Groundwater Quality Assessment Program Plan (GQAPP) was submitted to USEPA and OEPA. Beginning in March 1988, wells were sampled quarterly for one year. In March 1989, the GQAPP wass revised on the basis of a detailed evaluation of the available water quality and thow information. Forty-three wells were identilied for quarterly monitoring of 35 sitespecific analytical parameters. Another revision of the GQAPP was submitted in 
April 1991 to include findings from previous RCRA sampling, address regulatory comments, and provide more detailed sampling procedures. This revision also expanded the program by adding 11 more wells.

The RCRA Assessment Monitoring Program at the Fernald site was altered in 1991 when the RCRA Part A Permit Application identified 51 Hazardous Waste Management Units, including nine land-based HWMUs requiring groundwater monitoring. Before June 1991, Waste Pit 4 was the only identified regulated unit requiring groundwater monitoring. The RCRA Groundwater Monitoring Plan was submitted to the EPAs in December 1991, replacing the GQAPP. The Groundwater Monitoring Plan was designed to monitor groundwater downgradient of the nine land-based units. Three monitoring well networks were defined to provide adequate monitoring of the Waste Pit Area, the Production Area, and the site's property boundary.

By mid-1993, the property boundary network was near completion and well installattion on the Production Area network was proceeding. At that time, it was determined that it would be both impractical and impossible to meet RCRA requirements under the current monitoring program. Specifically, difficulties were encountered while trying to comply with RCRA requirements, causing a duplication of efforts in CERCLA and RCRA activities at the site.

In an effort to integrate CERCLA and RCRA monitoring activities under a single program, DOE proposed an Alternate Monitoring Program. This program is comprised of two components:

- Groundwater characterization activities under CERCLA as defined by the OU5 RI/FS Work Plan and Addenda, and

- Quarterly groundwater monitoring of the downgradient property boundary under the Routine Monitoring Program as defined in the "Project Specific Plan for the Routine Groundwater Monitoring Program Along the Downgradient Boundary of the FEMP."

The Project Specific Plan was submitted in July 1993 and defined the objectives of the Routine Monitoring Program. This program is comprised of 33 monitoring wells at the property boundary. including the monitoring wells installed for the downgradient facility boundary monitoring network defined in the RCRA Groundwater Monitoring Plan. In September 1993, after negotiations with DOE, OEPA issued the Director's Findings and Orders, which provided guidance on the Alternate Monitoring Program. identified elements to be included in the 1993 RCRA Annual Groundwater Report. and identified elements to be revised in the Project Specific Plan for the Routine Monitoring Program. A revision of the Plan was submitted to OEPA in October 1993.

Both the air and liquid pathways allow radioactive and non-radioactive materials to leave the Fernald site and are, therefore, monitored. The results from these monitoring activities are used to estimate potential radiation dose, which is discussed next in Chapter Seven. 

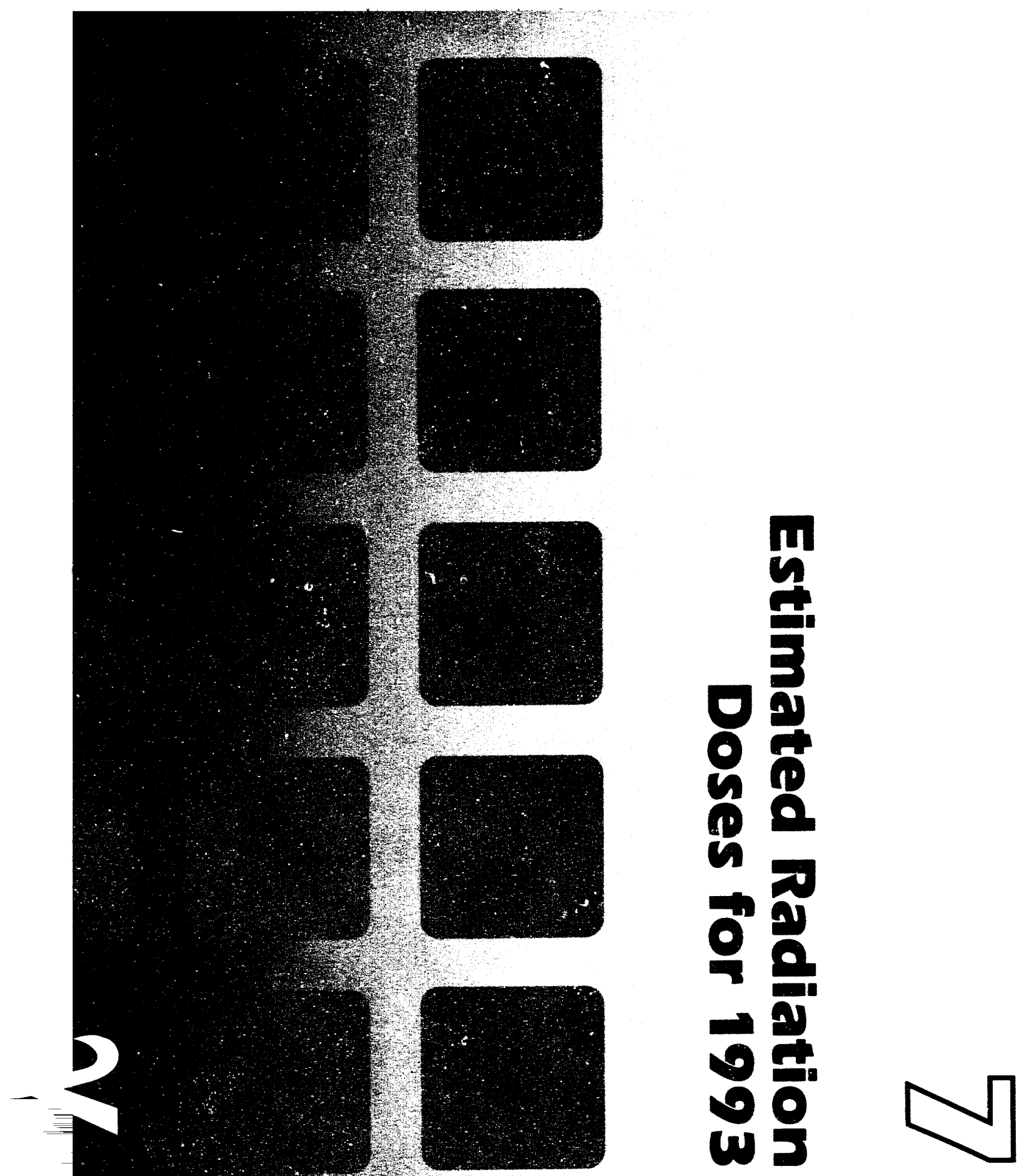


\title{
Estimated Radiation Doses for 1993
}

One of the chief public concerns about any facility that handles radioactive materials is that people working and living in the area may be exposed to harmful amounts of radiation. In response to this concern and envircrimental regulations, Fernald site personnel are monitoring the ways in which radioactive material could move through the environment and reach people. Background radiation levels and naturally occurring radioactive materials present technical as well as practical problems in trying to directly measure the dose people may actually rece've from the Fernald site; therefore, scientists estimate dose using models and the results of environmental samples. This chapter provides the following information:

- An explanation of how dose estimates are calculated,

- Dose estimates from several different pathways for 1993, and

- An interpretation of the significance of these estimated doses.

\section{Results in Brief: 1993 Estimated Doses*}

\begin{abstract}
Air Pathway
Airborne Emissions - The estimated maximum committed effective dose to a member of the public from 1993 airborne emissions was calculated as 0.016 mrem.
\end{abstract}

Foodstuffs - The committed effective dose from eating foodstuffs produced within three miles of the site was estimated to be $0.01 \mathrm{mrem}$.

Direct Radiation - There was no statistical difference between direct radiation measurements at the site fenceline and measurements at background locations. Therefore, no dose was attributed to direct radiation for 1993.

\section{Liquid Pathway}

Well Water - The estimated committed effective dose from drinking well water from the area around the Fernald site was 0.7 mrem.

Fish - The estimated committed effective dose from eating fish from the river near the Fernald site effluent line was $0.01 \mathrm{mrem}$.

\footnotetext{
* These doses for 1993 are also presented in Table 20 on page A-37. Information on
} doses received from other sources is also provided in that table. 


\section{Methodology for Calculating Total Radiation Dose}

DOE Orders and USEPA regulations require the Fernald site to demonstrate that its radionuclide airborne emissions are low enough to ensure that no one in the public receives an effective dose of 10 mrem or more in any one year. (This excludes radon222 emissions, which are covered under different regulations. Radon regulations, emissions, and estimated dose from radon are presented in Chapter Eight of this report.) Moreover, to determine whether the site is well within the DOE dose limit to members of the public of $1(x)$ mrem per year from all exposure pathways, Fernald site personnel estimate doses from other components of the air and licquid pathways, as well as direct radiation dose from materials stored onsite. The DOE limit of $I(x)$ mrem per year from all pathways is the sum of the doses from radiation external to the body during the year plus the dose from radionuclides taken into the body during the year. This latter dose is called the committed effective dose and is received over a 5()-year period.

As described in Chapter One, pathways are the routes along which radioactive material moves and may deliver a dose to the public. Total dose estimates incorporate dose from the air and liquid pathways. Direct radiation is included as a component of the air pathway dose. Monitoring of the air and liquid pathways provides the hasis for the extensive environmental sampling described in chapters Four, Five, and Six.

Using these measurements, a dose from each pathway can be estimated using models.

\section{Environmental and Dose Modeling}

The Fernald site, like many other nuclear facilities, uses models to estimate doses to the public. Models play an important role in environmental monitoring because current technology and the low concentrations of radioactive pollutants in the environment make it impractical to measure environmental doses with standard instruments. The nature of radioactivity and the presence of naturally occurring radioactive materials create difficulties in detecting low levels of radioactivity and distinguishing between natural radioactivity and radioactivity from the Fernald site. Models also estimate pollutant concentrations and doses which are below the detection capabilities of instruments and laboratory measurements. These concentrations and doses would be left out in assessing the environmental impacts of the site if models were not used. Environmental and dose models are briefly explained below.

Environmental modeling is a way to represent a complex environmental process, such as atmospheric dispersion of emissions or the air-to-soil-to-produce process, ats a set of mathematical formulas. By studying an environmental process, such as dispersion of a pollutant from a stack as it is carried by the wind, scientists can develop a mathematical formulat that models the process. They can then use this model to predict the concentration of the pollutant at a specific location. As additional processes are modeled, it is possible to interconnect them so that the movement of pollutants is predicted by a larger environmental model. 
Dose models are developed similarly. By modeling radioactive decaly, absorption and removal of radioactive materials in the body, and other physical and biological processes. scientists can develop a dose model to evaluate how radiondetive materials deliver a dose. Connecting the dose model to the environmental model provides a means of estimating dose using information gathered through envirommental sampling. Models are usually translatted into computer programs to conveniently handle the data and calculations.

Although models maly be the only comparative way for scientists to estimate dose, they do not necessarily predict all environmental processes. Since the mathematical formulas that represent the environmental and biological processes are simplifications and generalizations, applying them to the specific conditions at the site maly lead to differences between predicted and actual concentrations or doses. The results or outputs of models always involve some uncertainty in the accuracy of the estimated dose, and many have built-in assumptions which strongly influence the results. Models may be most beneficial because of their ability to estimate the upper limit of the dose and identify the most influential pollutant or pathway of exposure.

Although the uncertainty associated with the radiation dose calculations hats not been quantified, whenever Fernald-specific data were not available for parameter values (for example, food consumption values) conservative values were selected from the literature for use in the dose calculations. Thus, the estimated doses should be viewed as maximum estimates of potential doses resulting from Fernald releases.

\section{Air Pathway Dose Calculations}

The air pathway is a route for contaminants to reach people directly as emissions and indirectly through foods contaminated by airborne emissions. This section uses data from air and produce sampling as well an estimates of airborne releases (refer to Chapter Four) to calculate doses. Dose from radon is presented in the following chapter of this report.

\section{Estimated Doses from Airborne Emissions}

At the Fernald site, scientists obtain dose estimates from onsite airborne emissions measurements using a sel of computer programs called CAP-88. The site uses CAP88 to determine compliance with the NESHAP requirements of the Clean Air Act. Within the CAP-88 set of programs, the AIRDOS program calculates concentrations of radionuclides in the air, on the ground, and in food hased on estimates of the amount of airborne radioactive material released. The concentrations are then used io calculate the intakes and subsequent doses to people.

The CAP-88 program calculates airhorne radionuclide concentrations based on onsite airborne emissions measurements. The results from the fenceline ambient air monitoring stations are compared to the CAP-88 concentrations, but are not used in inhalation dose calculations. 
The (AP-88 computer programs calculate both individual and collective doses. Collective dose is the sum of individual doses to people in the fernald areat and is reported in the units of persom-rem. (For example, if 10 people each receive I rem, the collective dese is "I 10 person-rem:" if 20 people each receive 0.5 rem. that collective dese also is " "10 person-rem." The person-rem unit is used as a broad measure of the radiological impacts of the sife and is useful in comparing the risks from sile operations with other facilities and industries.

The ('AP-88 programs recpuire a large amount of datat to estimatte dose. which incluckes the number. height, and location of release points, wind speed and direction. the amount of radionactive material released. and population distribution in the Fernald areat. (Wind rose dalta are shown in figures 4 and 5 in ( haupler ( )ne. and estimated airborne radionticlide emissions and population distribution are presented in tables 2 and 21.) Although some of the diatla were obtained through measurements and sampling. many were not readily atailable and were estimated. lixamples of estimated datta are the announts of airborne radionctive material released from the Latoratory Building and the Cooling Tower. The site made very comservative esvimates for these and all wher emission sources which were not measured directly. Conservative estimates, used frequently in environmental monitoring and done calculations, are based on assumptions aboul an exposure siluation that should result in the highest estimale of a dose. lor example. an assumption aboul extimated doses at the air monitoring stations is that a person

Figure 45: Department of Energy Dose Limits

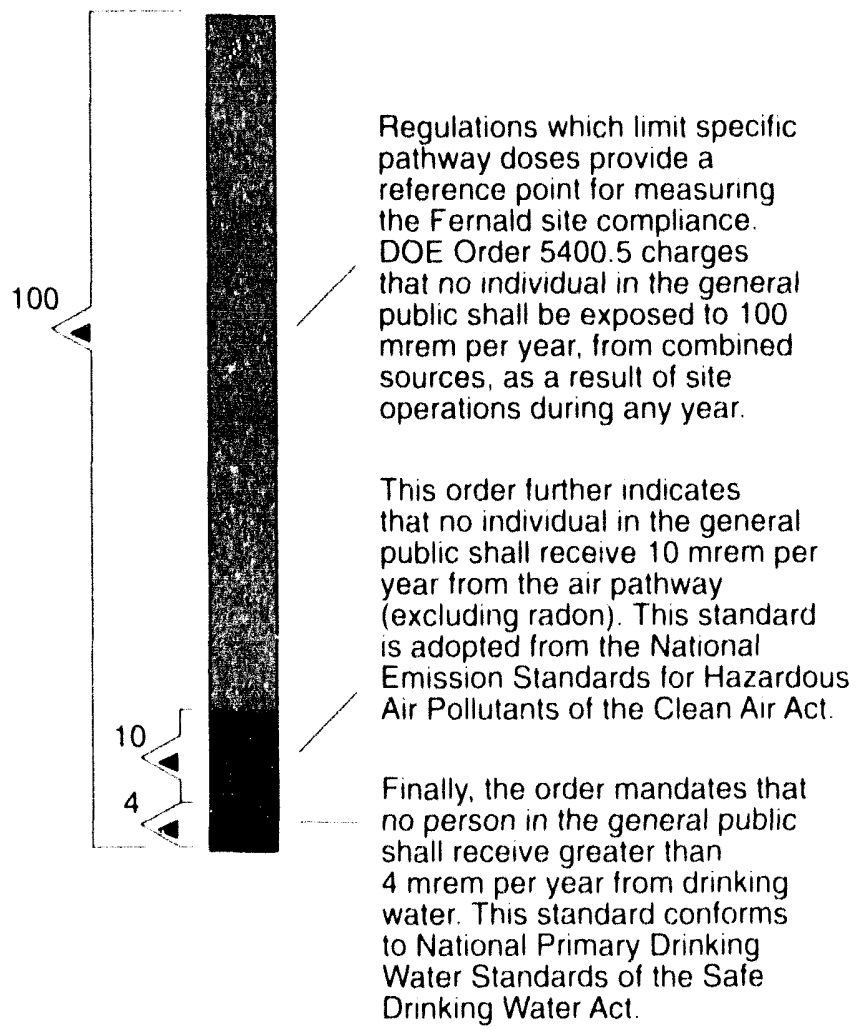

is outdens al onc loxation for lox)e of the lime during the year. The assumptions are comservative in the semse that they provide a matrgin of error for underestimating cmis sions and doses. (omservative estimbales of emissioms are used lo ensure thall dose entimattes alle not underestimatled hut alre the maximum doses that could have resulted from site operattions during 1993.

Results of the ('AP's programs c'stimatted the maximum effective dose from lwe? airborne emissiom lo be (0.016 mrem to a person lecalled north of the former production areat. This dose estimbate assumed that the person remained outside his or her home l(x)/ of the lime in 1903. The dese wiss well below the NI:SHAP standard of 10) mrem from the air pathway and was only (0.0) $6 \%$ of the 1 () ) : g guideline of $I(x)$ mrem per year from all pathways sece ligure +5$)$. 
The collective effective dose from 1993 airborne emissions (nol including radon) to the population within $80 \mathrm{~km}(50)$ miles) of the site was also calculated by CAP-88. This dose was estimated to be (0.3 person-rem for a population of 2,740),(6)(0). For comparison. the same group of people received an estimated collective effective dose of $3(X),()(K)$ person-rem from background radiation. excluding radon.

\section{Estimated Dose from Eating Foodstuffs Produced near the Fernald Site}

Since the CAP-88 program only calculated doses from 1993 airborne smissions, scientists made addditional dose calculations to estimate doses from past emissions that may have accumulatted through the food chain. These additional calculations extimate potential dose from consuming locally grown fruits, vegetables, and milk.

Uranium deposited in soil during the years the Fernald site wass in production may be absorbed by produce and farm animals and, therefore, deliver a secondary pathway dose. This estimated dose is hased on the conservative assumption that 10(0)\% of a person's diel of fruit. vegetables, and milk comes from gardens and farms in the Fernald area. This modeled diet assumes an annual consumption of $18 \mathrm{~kg}$ (40) pounds) of leafy vegetables (cabbage. lettuce, etc.). $4.5 \mathrm{~kg}(1(0)$ pounds) of grains (corn, soy beans. wheall, etc.), $68 \mathrm{~kg}(1.50$ pounds) of fruit. $28 \mathrm{~kg}$ ( 62 pounds) of below-ground vegetahles (potatoes, carrots, etc.), $45 \mathrm{~kg}$ ( $1(\%)$ pounds) of other vegetables, and 112 liters (30) gallons) of milk. "Scientists analyzed cabbage, corn, soybeans, apples. potatoes. tomatoes. cucumbers, and milk sampled from local gardens and farms for uranium to represent the foods in the diet. The maximum uranium concentration found in locally produced foods was used to estimate dose. The average background uranium concentration in foods was subtracted from the maximum concentration to account for the natural occurrence of uranium in foods.

The laboratory analysis of fiogdstuffe determines the total amount of uranium (all uranium isotopes) in the sample. Because any dose from uranium is hased on the isotopic composition of uranium, an assumption about the isotepic composition of uranium in foodstuffs must be made to calculate the dose. Scientists assume any uranium detected in the foodstuffs has the isotopic composition of natural uranium. This assumption is reasonable because a large amount of uranium produced at the Fernald site had an isotopic composition similar to naturally occurring uranium. Scientists used dose conversion factors to convert the intake of uranium to dose. The conversion factors themselves are the result of modeling the radioactive decay and metaholism of radionuclides in the body. ${ }^{7}$

The committed effective dose received over the course of 50 years was calculated to be $0.01 \mathrm{mrem}$, only $0.01 \%$ of the DOE dose limit of $I(0)$ mrem per year for all pathways. This dose is comparable to the estimatted doses from foodstuffe in past years. 


\section{Direct Radiation Dose}

Unlike the air and liquid pathways where a radionuclide in the form of a particulate or gas delivers its dose after inhalation or ingestion, direct radiation dose is the result of radiation (gamma and X-rays) emitted from radionuclides stored onsite. The largest sources of direct radiation are the wastes stored in the K-65 silos and thorium compounds stored at several locations onsite. Direct radiation dose is estimated using environmental thermoluminescent dosimeters (TLD) measurements (see Chapter Four), rather than through the use of models.

Direct radiation dose was estimated using the highest dose from the twelve fenceline monitoring locations (see Table 10 on page A-14) and subtracting the average dose measured at three background TLD locations (locations 18, 19, and 20) as shown in Figure 27 on page 79). Limits in the precision on TLD data and variations in natural background radiation require consideration of the uncertainty (the plus/minus ( \pm ) values) associated with each measurement in calculating dose. The uncertainty is calculated for a $95 \%$ confidence interval ( 2 sigma) about the average.

From the data in Table 10, the highest 1993 fenceline dose oceurred at location 15 and is $7.3 \pm 9 \mathrm{mrem}$ per year ( 2 sigma). The average background dose from locations 18, 19, and 20 is $61 \pm 1.5$ mrem per year. At first glance, it appears that the direct radiation dose would be 12 mrem per year above background at the site fenceline. However, when the range of the background dose measurements is taken into account, there is no statistical difference between the fenceline dose and the average background dose. The data indicate that the highest fenceline dose is between 64 mrem per year (7.3-9) and 82 mrem per year (7.3+9), while the average background dose is between 46 mrem per year (61-15) and 76 mrem per year $(61+15)$. Since the range of hackground doses largely envelops the range of fenceline doses, there is no firm basis for stating that there is a difference between the fenceline and average background doses. Given this lack of statistical difference between the doses, no dose was attributed to direct radiation for 1993.

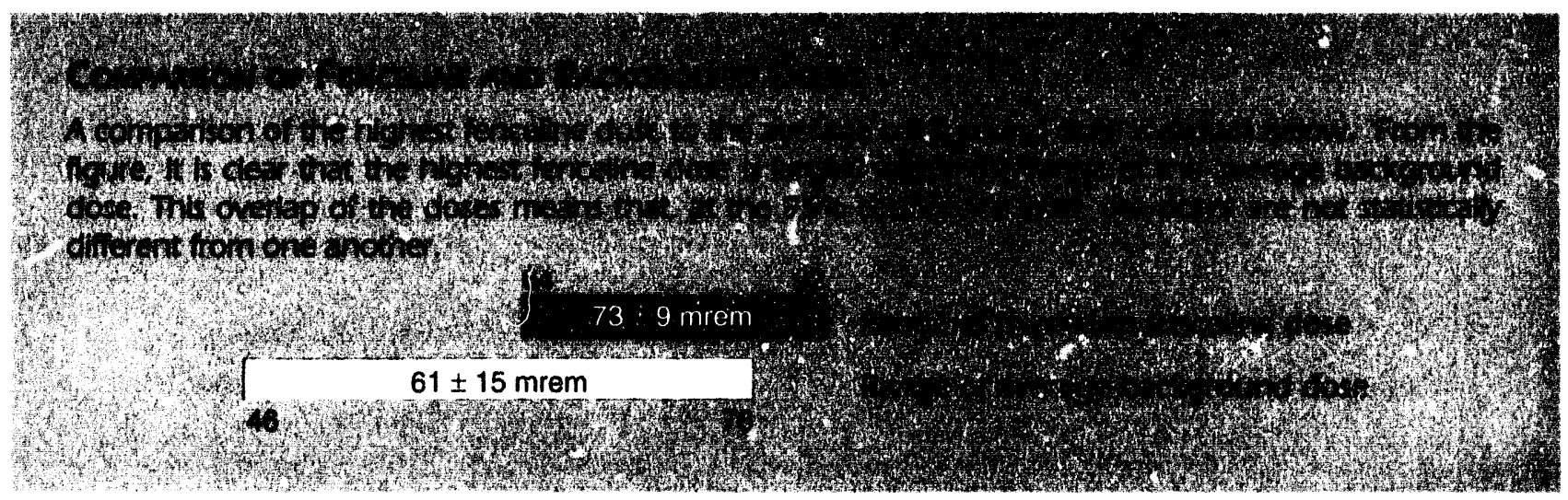




\section{Liquid Pathway Dose Calculations}

Dose estimates from the liquid pathway are calculated using environmental sample results and dose conversion factors. Measurements of radionuclide concentrations in groundwater, the Great Miami River, and fish from the river are used to estimate dose from the liquid pathway. Descriptions of the monitoring programs for these environmental samples are given in chapters Five and Six.

\section{Estimated Dose from Drinking Well Water in the Area around the Fernald Site}

As discussed in Chapter Six, the site monitors a number of private drinking water wells for uranium contamination. While most wells have uranium concentrations which are within the 0.07 to $2 \mathrm{pCi} / \mathrm{L}(0.1$ to $3.0 \mathrm{ppb})$ range of background concentrations, several wells have higher concentrations and are considered to be a source of dose from the site.

In order to estimate dose from drinking well water in the area around the site, the average uranium concentration in wells located north and west of the site was subtracted from the maximum concentration found in wells located south and east of the site. Data from wells 1, 3, 4, 10, 22, and 30) were used to provide the average background concentration. The maximum concentration in a drinking water well south and east of the site was found in Well 34. For the purpose of dose calculation. the tranium in Well 34 is assumed to have the isotopic composition of natural uranium. Using a consumption rate of 2 liters ( $(0.5$ gallon) of water per day, the committed effective dose received from drinking water from Well 34 would be $0.7 \mathrm{mrem}$.

\section{Estimated Dose from Drinking Great Miami River Water}

Although the Great Miami River downstream of the site is not designated as a public water supply hy OEPA, the site estimated the radiation dose $t o$ an indiviuial if that person drank only the water from the river downstream of the discharge point after mixing had occurred.

Scientists used data on the amounts of radionuclides discharged to the Great Miami River (see Table 1 ! on page A-15) and the average river flow to calculate concentrattions in river water. Dosse conversion factors were used to convert the intake of radionuclides to dose. Assuming a daily consumption of 2 liters ( $(0.5$ gallon) of water. the committed effective dose from Fernald releases received over the course of 50 years would be 0.01 mrem. ${ }^{36}$ 


\section{Estimated Dose from Eating Fish from the Great Miami River}

The estimated dose from eating fish from the river was calculated using the maximum uranium concentration in edible fish collected at RM 19 and RM 24 (see Figure 35 in (hapter Five). The average background uranium concentration in edible fish collected at RM 38 was subtracted from the maximum concentration to account for natural occurrence of uranium in the fish. As with other dose calculations, any uranium detected in the fish was assumed to have the isotopic composition of natural uranium.

Assuming an annual consumption of $4.5 \mathrm{~kg}$ ( 10 pounds) of fish from the Great Miami River, the committed effective dose would be $0.01 \mathrm{mrem} .{ }^{36}$ This dose is well below the DOE guideline of 100 mrem effective dose per year from all pathways.

\section{Total of Doses to a Maximally-Exposed Individual}

Figure 46: Dose to Maximally-Exposed Individual, $1989-1993$

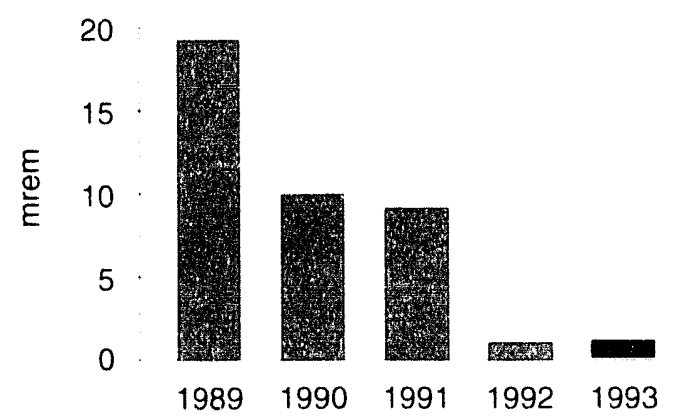

The maximally-exposed individual is a hypothetical member of the public who receives the highest calculated effective dose based on the location of his or her home, weather conditions, and the individual pathway doses. Since it is not possible to single out a specific individual in the Fernald area who receives the most dose, the results of the individual pathways and the CAP- 88 evaluation are added to predict the maximum dose that a person could receive. The dose to the maximally-exposed individual is a total of estimated doses from breathing 1993 airborne emissions (excluding radon). consuming foodstuffs produced in the Fernald area. drinking water from a well in the Fernald area. eating fish from the Great Miami River, and the direct radiation dose above background at the site fenceline. The conservative assumptions used throughout the dose calculation process ensure that the dose to the maximally-exposed individual is the upper limit of the actual dose any member of the public receives.

The dose to the maximally-exposed individual is estimated to be 1.0 mrem, well below the guideline of 100$)$ mrem per year for all pathways. Figure 46 shows the doses (o) the maximally-exposed individual from 1989 to 1993. 
DOSE TO MAXIMAUY EXPOSED INDMDUNL.

Pathway

Estimated 1993 emissio 75

Foodstuffs grown in Fernald area

Direct radiation

Liquid

Well water in the Fernald area

Fish from Great Miami River
Dose Attributable

to the site

$\begin{array}{lll}0.016 & \mathrm{mrem} & 10 \mathrm{mrem} / \mathrm{air} \\ 0.01 & \mathrm{mrem} & 100 \mathrm{mrem} / \mathrm{all} \text { pathways } \\ 0.0 & \mathrm{mrem} & 100 \mathrm{mrem} / \text { all pathways }\end{array}$

0.7 mrem

0.01 mrem

\section{Applicable Guideline}

100 mirem/all pathways

Maximallyexposed individual $\quad-1.0 \mathrm{mrem} \quad 100 \mathrm{mrem} / \mathrm{all}$ pathways

\section{Significance of Estimated Radiation Doses for 1993}

One method of evaluating the significance of the estimated doses is to compare them with doses received from background radiation (see Chapter Two). Background radiation yields approximately 100 mrem per year from natural sources, excluding radon. Comparing the maximally-exposed individual dose to the background dose demonstrates that, even with the conservative estimates, the dose from the site is much less than background. Although the estimated dose will be received in addition to the background dose. this comparison provides a basis for evaluating the significance of the estimated doses. A dose that is small in comparison to that of background radiation will produce no measurable health effects.

Another method of determining the significance of the estimated doses is to compare them with dose limits developed to protect the public. The International Commission on Radiological Protection (ICRP) has recommended that members of the public receive no more than 100 mrem per year as a result of site operations, and DOE has incorporated this limit into Order 5400.5 as well. The sum of all estimated doses from site operations for 1993 was well within this limit.

Radon is subject 10 different regulations than other components of the air pathway. Likewise, the dose received from radon is regulated separately. Therefore, the Radon Monitoring Program is discussed separately in the next chapter, as well as the dose received from radon at the Fernald site. 


\section{Estimated Radiation Doses for 1993}

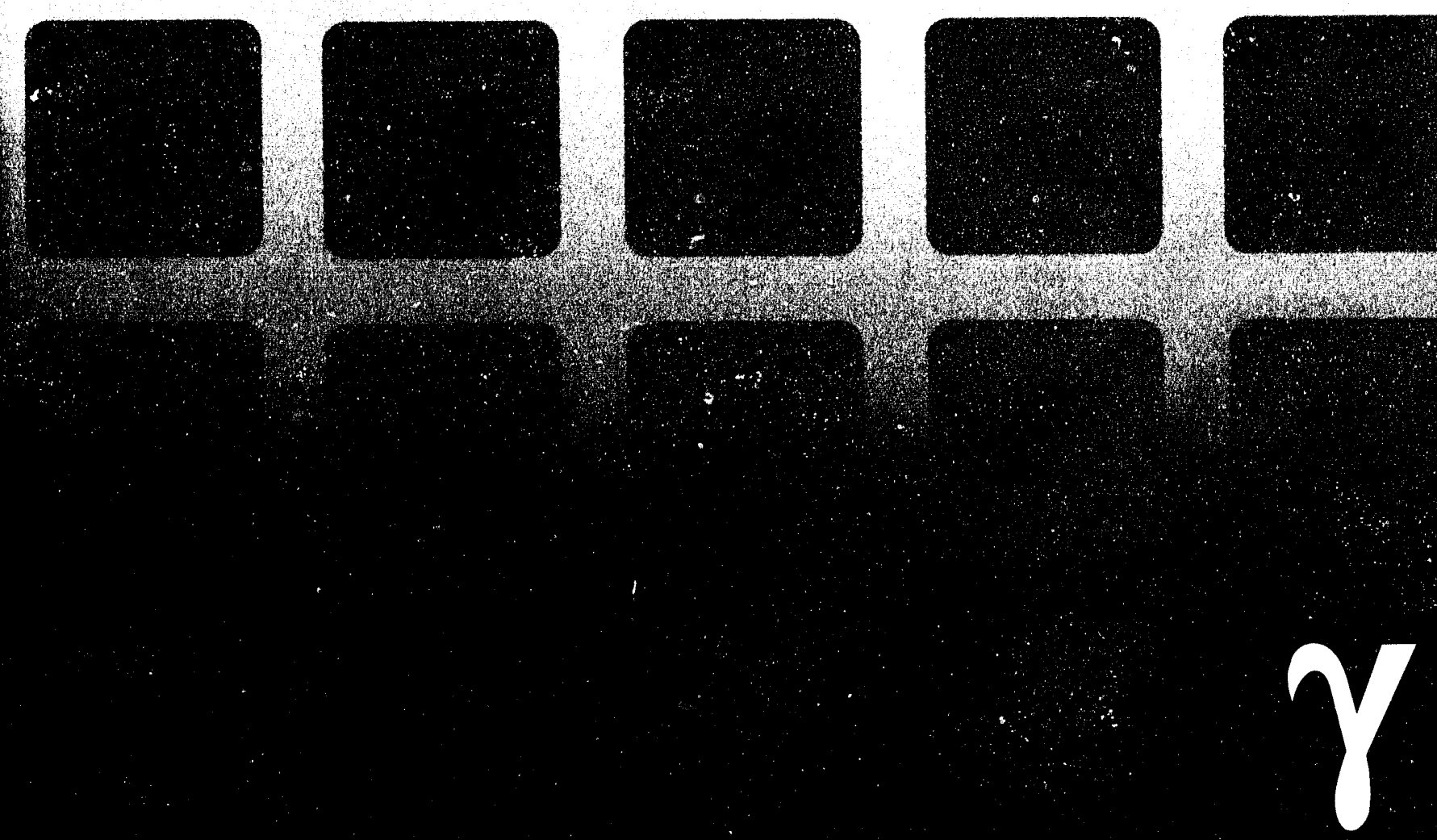




\section{The Radon Monitoring Program}

Radon is a radioactive gas that occurs naturally throughout the environment. Everyone is exposed to radon at varying concentrations, and exposure to radon is part of the annual background radiation dose that people receive. As discussed in Chapter Two, this background exposure contributes approximately $55 \%$ to a person's average annual dose.

In addition to the radon found naturally in the environment, the Fernald site stores some materials onsite that radioactively decay to form radon. Because these materials are present, the Radon Monitoring Program has monitored radon levels onsite since the early 1980 s. This program operates in compliance with the requirements of DOE Order 5400.5, "Radiation Protection of the Public and the Environment." Radon monitoring results and attributable dose are reported separately from the air pathway in order to improve the presentation of information and regulations that are unique to radon.

\section{Results in Brief: 1993 Radon Monitoring}

Fenceline Concentrations - Average fenceline concentrations measured in 1993 were $0.63 \pm 0.20 \mathrm{pCi} / \mathrm{L}$, well below the DOE guideline of $3.0 \mathrm{pCi} / \mathrm{L}$. The 1992 results were $0.57 \pm 0.29 \mathrm{pCi} / \mathrm{L}$.

Dose Received from Radon - The calculated dose at the fenceline was estimated to be 454 mrem incorporating the methodology used by the National Council on Radiation Protection. The 1992 dose would have been 410 mrem at the fenceline if the same dose calculation method had been used. These dose calculations include the annual dose received from average background levels of radon lapproximately $\mathbf{2 0 0}$ mrem per year), and they were calculated using a more conservative method than was previously used. 


\section{Introduction to Radon}

The general term radon refers to the radon-222 isotope. Radon-222 is a naturally occurring decay product of uranium-238 which is widespread in the earth's crust. Radon-222 has the longest half-life of the radon isotopes, 3.8 days, which allows for radon-222 to be a significant contributor of radon exposure to the public. Radon-222 is virtually everywhere because of the widespread distribution of its parent radionuclides, radium-226 and uranium-238, in the earth's crust. The other isotopes of radon found in the environment are radon-219 (actinon), a daughter in the uranium-235 decay chain and radon-220 (thoron), a daughter in the thorium-232 decay chain. The decay chains for the parents of the radon isotopes are shown in Figure 47.

Radon-222 decays into a series of short-lived radionuclides that are collectively referred to as radon "daughter products." As radon and its daughter products decay, alpha particles are emitted. The daughter products are adsorbed on inert dust present in the atmosphere. When the dust in the atmosphere is inhaled with the attached daughter products, some of this dust is deposited in the lung, which may cause an internal exposure to the lung. These daughter products, which are deposited in the lung, will emit alpha particles when they decay. The alpha particles may then cause damage to the cells lining the airways.

Radon-220, or thoron, with a half-life of 55.6 seconds, behaves similarly to radon222. Individuals may receive an internal exposure to the lungs, due to inhaling dust with attached thoron daughters. However, the dose to the lung from thoron and its daughters does not add significantly to the dose received from the radon series.

\section{Radon in the Environment}

Radon-222 is present in the environment virtually everywhere because of the widespread distribution of its parent radionuclides, radium-226 and uranium-238, in the earth's crust. The physical characteristics of the soil and local weather conditions affect radon's ability to migrate into air and water. Upon decay, radon may escape into the air spaces around soil particles and diffuse into the atmosphere. Local rainfall and snowcover may inhibit radon's ability to escape from the soil.

The outdoor concentration of radon in the atmosphere shows daily, seasonal, and annual fluctuations. These changes are caused, in part, by atmospheric conditions. They are also caused by changes in the rate that radon is released from the ground because of precipitation and freezing temperatures. Because radon tends to accumulate under stagnant weather conditions, concentrations increase during periods of calm winds and temperature inversions. (During temperature inversions, warm air traps cooler air near the earth's surface and prevents mixing and turbulence of the air near the surface. When these inversions occur, radon is also trapped near the earth's surface.) 

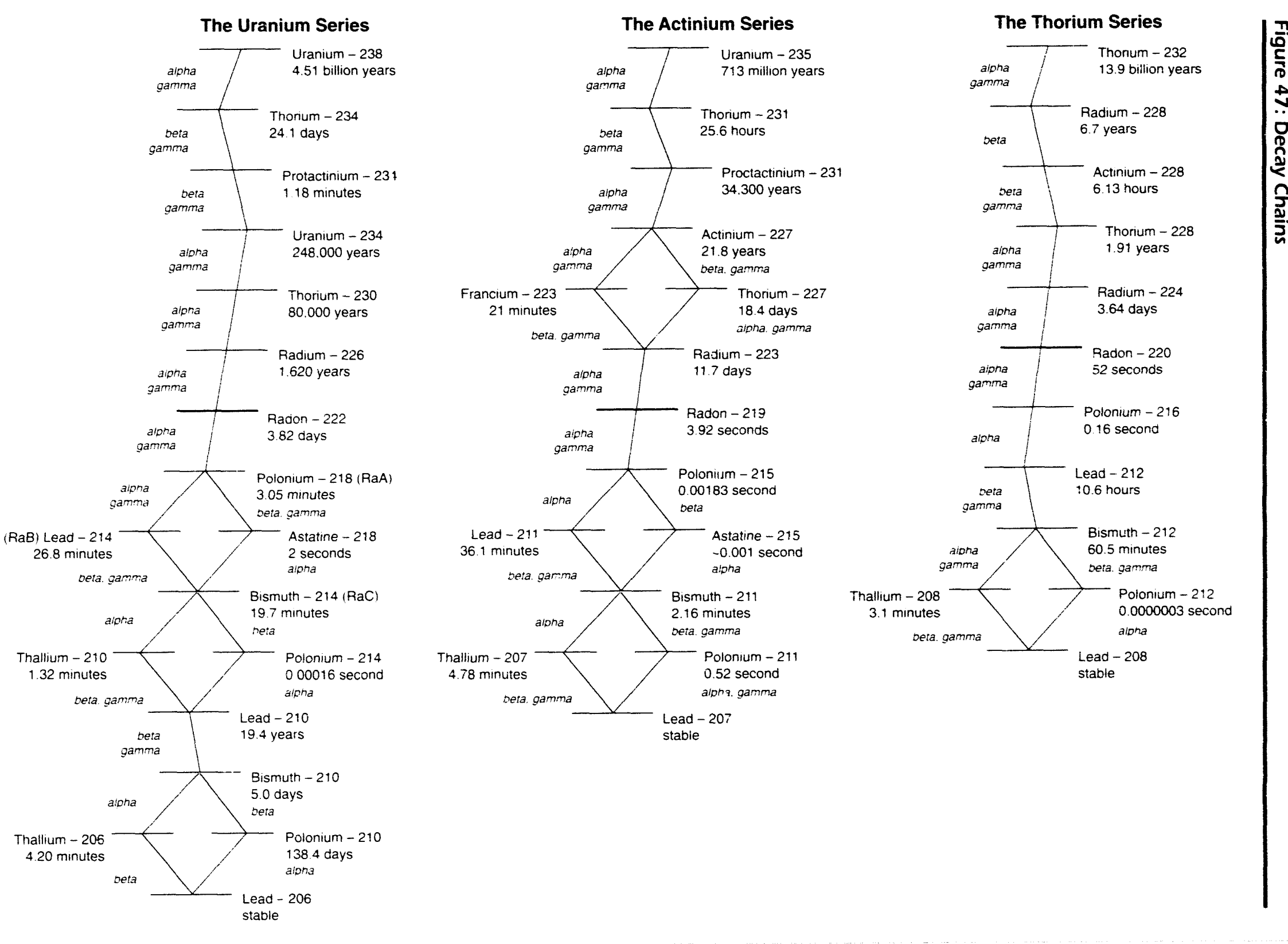


\section{Radon at the Fernald Site}

In addition to the radon formed naturally in the environment, the Fernald site stores some materials which radioactively decaly to form radon. The principal source of radon emissions from the site is the $\boldsymbol{K}-\mathbf{6 5}$ silos. The silos contain high concentrations of radon producing elements. Radon can escape through the cracks and access ports on top of the K-65 silos.

The site was required by the Federal Facility Agreement (FFA) to measure radonflux from all waste pits known to contain radium. These measurements were laken at pits 1,2 , and 3 in 1991 , and all were below the $20 \mathrm{pCi} / \mathrm{mn}^{2}$ per second standard. In January 1993, DOE verified with USEPA that emissions from Waste Pit 4, which is covered with a clay cap and liner. were below the 2() $\mathrm{pCi} / \mathrm{m}^{2}$ per second standard and was, therefore, exempt from the requirement. Because pits 5 and 6 and the Clearwell are water covered, radon-flux measurements would not be required if the exposed material above the water line was submerged. After completion of the "Control of Exposed Material in Waste Pit 5" and "Control of Exposed Material in Waste Pit 6" removal actions. all exposed material was submerged, and radon-flux measurements for these pits were not required.

\section{Radon Monitoring at the Fernald Site}

All releases applicable to site activities are monitored at each DOE facility and radiation exposures to members of the public are assessed. This monitoring provides assurance that members of the public and the environment are protected from radiation exposure.

Radon concentrations and emissions in the atmosphere above facility surfaces or openings are guided by DOE Order 540().5, "Radiation Protection of the Public and the Environment." This order defines radiological protection requirements and guidelines for cleanup of residual radioactive material, the management of resulting wastes and residues, and the radiological release of property. These requirements and guidelines are applicable at the time the property is released. These requirements state that radon levels must not exceed the following limits when added to background levels:

- $\quad$ (1)( $\mathrm{pCi} / \mathrm{L}$ at any given point.

- An annual average concentration of $30 \mathrm{pCi} / \mathrm{L}$ over the facility site,

- An annual average concentration of $3 \mathrm{pCi} / \mathrm{L}$ at or above any location outside the facility site, or

- Flux rates greater than $20 \mathrm{pCi} / \mathrm{m}^{2}$ per second from the storage of radon producing wastes. 


\section{Monitoring Methods}

The Environmental Radon Monitoring Program at the Fernald site uses two types of radon detectors to measure radon concentrations in the environment: alpha-track etch detectors and alpha-scintillation detectors.

An alpha-track etch detector is a cup that contains a special plastic chip inside. Some of the alpha particles from the decay of radon (or its daughter products) will interact with the plastic chip by leaving a latent track in the material. The tracks are made detectable by chemical or electrochemical etching. The number of etches or tracks in the material is proportional to the number of alpha particles that have reached the plastic. This number can then be related to the average concentration of radon in the cup. Filters are placed over the cup to allow only radon to enter the cup and be measured. All environmental radon data presented in this 1993 report are from the alpha track-etch radon detectors, and pertinent environmental data can be found in Table 22 on pages A-39 and A-40. These detectors are exchanged every three months to provide long-term radon measurements.

The Environmental Radon Monitoring Program obtains data from 20) locations at the site boundary using alpha track-etch detectors, as well as from three area residences and four background locations (see Figure 48). The background locations are shown as air monitoring stations 15 and 16 and background locations 1 and 2. Alpha track-etch detectors were also used to measure radon concentrations adjacent to the silos and in the predominant wind direction from the silos (see Figure 49).

Alpha-scintillation detectors use alpha-scintillation cells to continuously monitor radon concentrations. These continuous monitors record radon concentrations on an hourly basis. An alpha-scintillation cell detects alpha particles from the decay of radon gas by the interaction of the alpha particle with the material inside the scintillation cell. The interactions produce light pulses which are amplified and counted. The number of light pulses counted is proportional to the radon concentration inside the cell. When monitoring the ambient outside air, the air diffuses into the scintillation cell through a foam barrier. The radon gas present in the diffused air decays into its daughter products, emitting alpha particles which are then counted. This technique is called passive sampling. It takes approximately a half-hour to achieve the same radon gas level inside the cell as is present in the surrounding air.

Continuous monitoring was conducted at select fenceline locations during 1993, namely, air monitoring stations 1, 6, and 7. Continuous monitoring was also conducted at various focations on site. These locations include the perimeter of the silo berm and headspace of the silos. The locations of these monitors are shown in Figure 5). Although the data obtained from the continuous monitoring are not included in this report. some of the data are reported to USEPA through the Federal Facility Agreement. 


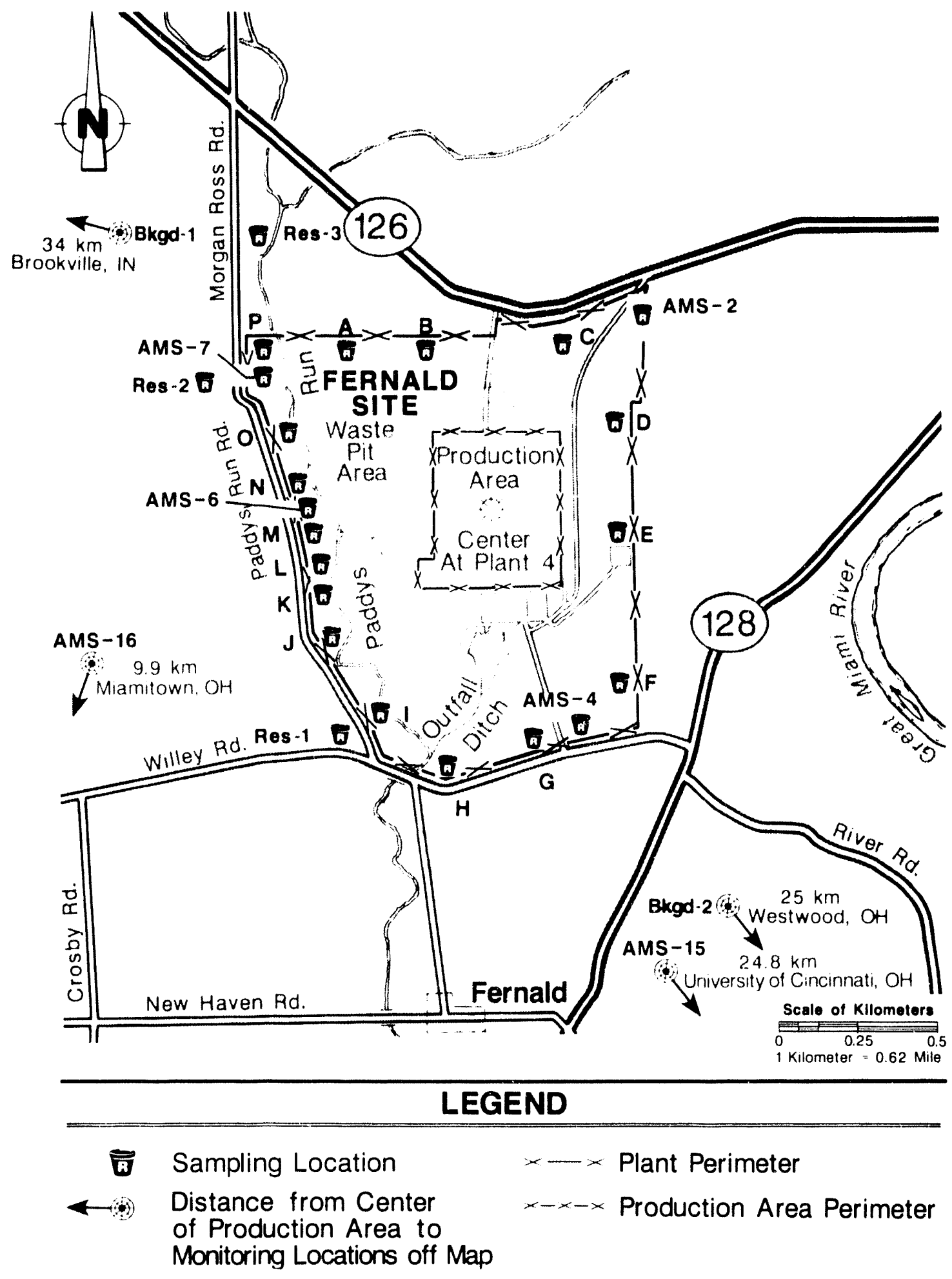




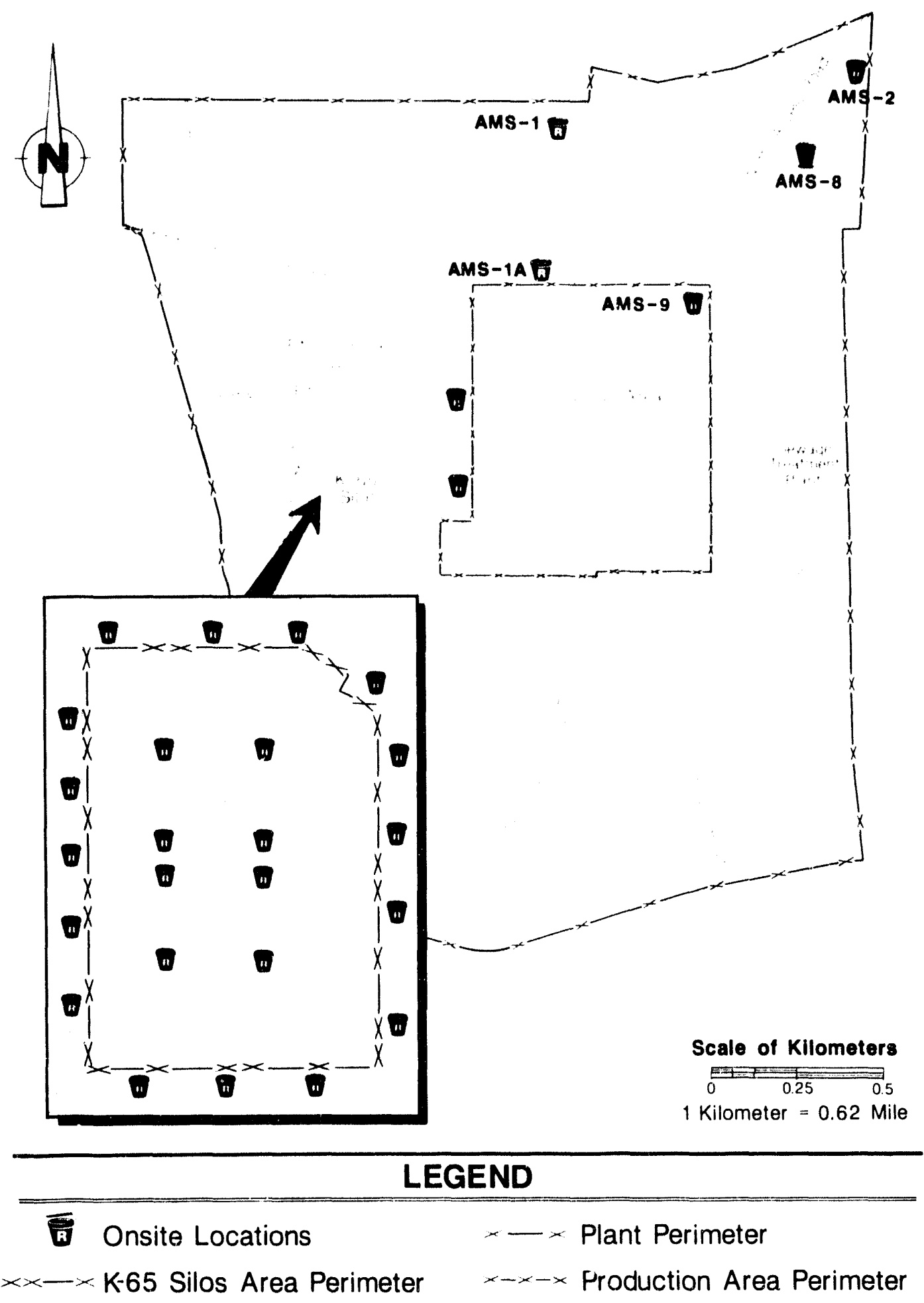




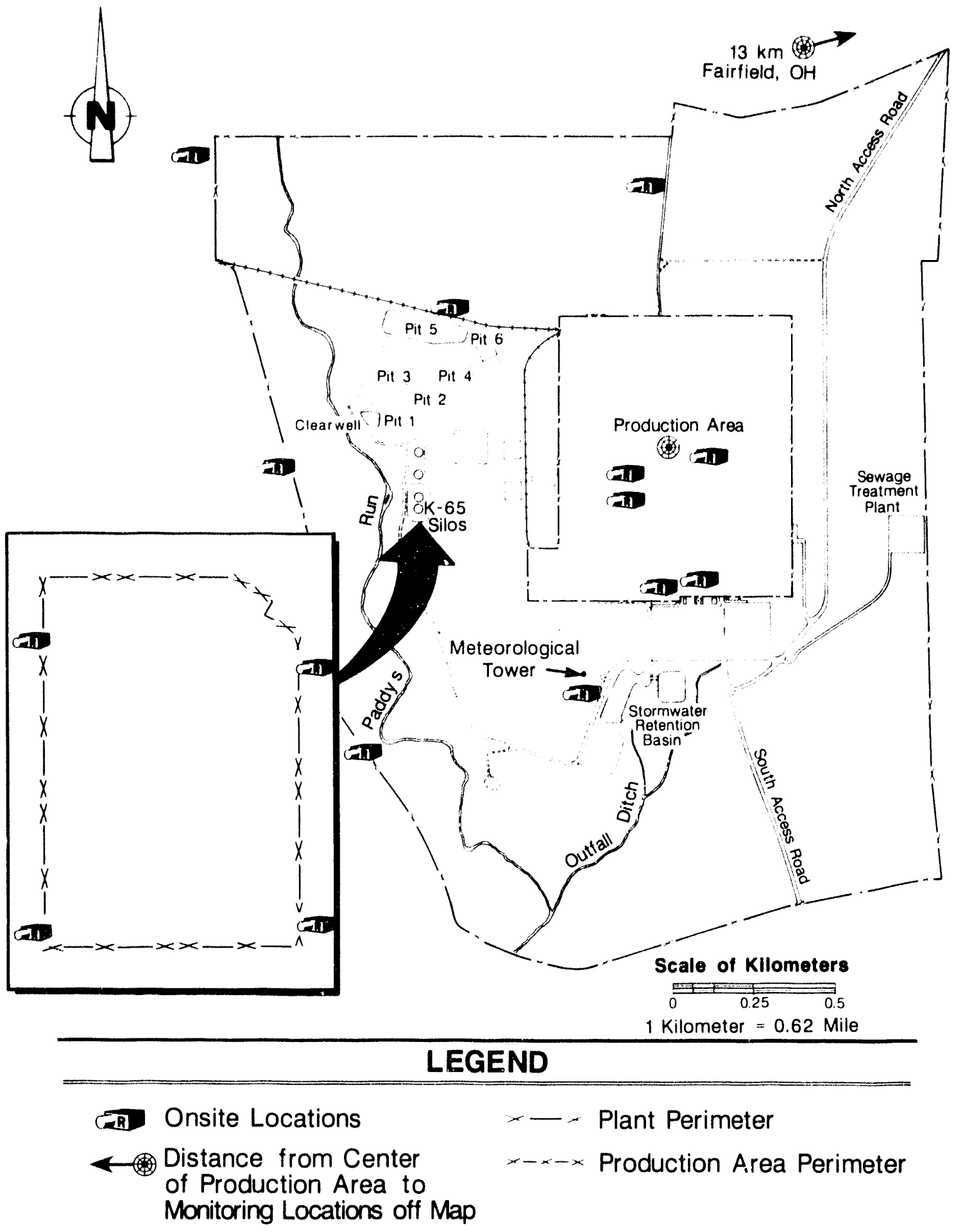




\section{Environmental Radon Monitoring Results}

Table 22 on pages A-39 and A-40 summarizes the 1993 environmental radon monitoring results. These quarterly results are also shown in Figure 51. Average fenceline radon concentrations were considerably less than the DOE limit of $3.0 \mathrm{pCi} / \mathrm{L}$. The average radon concentration at the fenceline was $0.63 \pm 0.20 \mathrm{pCi} / \mathrm{L}$. The range of values for any location on the fenceline varied from less than $0.1 \mathrm{pCi} / \mathrm{L}$. to a maximum of $1.58 \mathrm{pCi} / \mathrm{L}$. The maximum measurement was still considerably less than the DOE limit.

The average background radon concentration was greater than the average fenceline concentration in 1993. The results in Table 22 show that all monitored locations demonstrated a significant increase in radon concentrations during the third and fourth quarters of 1993. The average background radon concentration for 1993 was $0.95 \pm$

Figure 51: Quarterly Fenceline Radon Concentrations, 1993

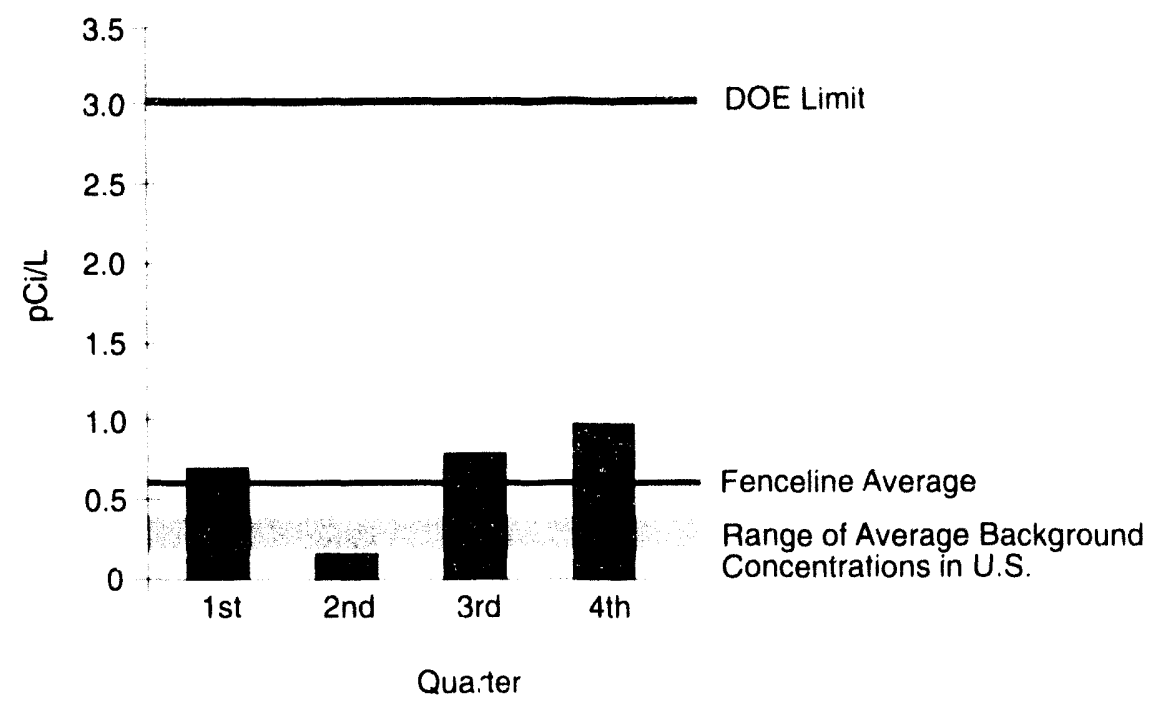

$0.24 \mathrm{pCi} / \mathrm{L}$. The concentration for any of the four background locations varied from $0.13 \mathrm{pCi} / \mathrm{L}$ to a maximum of $2.15 \mathrm{pCi} / \mathrm{L}$.

Quality assurance problems were noted with the vendor analytical services in 1993, which rendered some of the quarterly data suspect. The vendor reported high errors in background sample concentrations in the magnitude of several hundred percent. Therefore, the radon data reported here are more of a qualitative nature than quantitative and serve as a general indicator of relative radon concentrations. Radon data obtained by other monitoring techniques supported an apparent increase in background radon oncentrations for the third and fourth quarters, but it was substantially lower than the data reported with the track-etch cups.

Since the 1993 background locations yielded radon concentrations much higher than the typical values for ambient outdoor radon concentrations throughout the country, different locations may need to be selected to find locations that are more representative of background. The third and fourth quarter background concentrations were extremely high in 1993. Background locations with concentrations less than onsite concentrations are needed for valid comparisons with onsite radon data to assess offsite radon contributions attributable to the Fernald site. 


\section{Estimated Radiation Dose from Radon}

The radiation dose from radon in 1993 was estimated using a methodology that is more conservative than previous estimates. The methodology used incorporates that which is used by the National Council on Radiation Protection (NCRP) ${ }^{33}$

In 1993, the dose from radon was estimated to be $4.54 \mathrm{mrem}$. This dose was calculated from the average annual fenceline radon concentration. As was previously stated, the average background radon concentration was greater than the average fenceline concentration. The radon dose calculation here is only useful for comparing the dose from "nitural" radon at the fenceline to the estimated national background average of 200 mrem. The chart below presents the 1993 dose estimates for 199.3 including any background radon present at the fenceline. For comparison purposes, the chart also presents 1992 radon dose estimates using the same methodology as was used in 1993. The changes used in this year's calculation methodology are expected to be continued in the future.

\section{Radon Dose Estimates at the Fenceune}

\begin{tabular}{lccl}
\hline Annual Average Fenceline Values & 1993 & 1992 & Comments \\
\hline Radon Concentration, (pCi/L) & 0.63 & 0.57 & \\
\hline Estimated Dose, (mrem) & 454 & 410 & $\begin{array}{l}\text { Individual engaged in light activity } 24 \text { hours } \\
\text { a day }\end{array}$ \\
\hline Estimated Dose, (mrem) & 403 & 365 & $\begin{array}{l}\text { Individual engaged in light activity 16 hours a } \\
\text { day, 8 hours resting }\end{array}$ \\
\hline Estimated Dose, (mrem) & 189 & 171 & $\begin{array}{l}\text { Dose estimated using 1992 methodology } \\
\text { (assuming 50\% equilibrium), including } \\
\text { background }\end{array}$
\end{tabular}

The 199.3 dose estimate assumed that the ambient concentration ratio of radon to radon daughters offsite (radon-222: $\mathrm{RaA}: \mathrm{RaB}: \mathrm{RaC}$ ) was at a ratio of 1:(0.9:0.7:().7 approximately a ().7 equilibrium ratio. (Figure 47 on page 129 labels radon-222 daughters $\mathrm{RaA}, \mathrm{RaB}$, and $\mathrm{RaC}$.) This ratio for ambient outside air is in accordance with widespread sampling conducted throughout the United States that is referenced in the NCRP report. Actual values for radon daughters have not been measured at offsite or fenceline monitoring locations.

The dose estimate also assumed that the dose was calculated for a maximallyexposed individual who continuously breathed air at the fenceline while engaged in light physical activity for 24 hours a day for an entire year. The dose estimates presenteci in this report are for the "standard person," which assumes an average body size and breathing rate. 
An exposure conversion factor, using the above mentioned assumptions, was used to calculate the radiation exposure to the lung from radon and its daughters based on radon concentrations in the air. The exposure was converted to a lung dose by using the quality factor for internal alpha particles. ${ }^{39}$ The lung dose was converted to an estimated dose equivalent (whole body dose) by using the weighting factor for the lung."

The second dose estimate is presented to illustrate the effects of changing any one factor in the calculation of an estimated dose from radon. This estimate used a more realistic assumption that the hypothetical person continuously breathed air at the fenceline for 24 hours a day but spent 8 hours resting and 16 hours engaged in light activity each day for the entire year. Dose estimates for radon use variables with a range of possible values. Therefore, the radon dose conversion factor can be as high as approximately $120 \%$ of the values reported if all parameters except the radon-222 concentration are unspecified.

\section{Control of Radon at the Fernald Site}

DOE strives to operate its facilities and conduct its activities so that radiation exposures to members of the public are As Low As Reasonably Achievable (ALARA).

Steps have been taken at the site to control radon emissions. In November 1991, a bentonite (clay) sealant layer was placed over the residues contained in the K-65 silos to reduce the amount of radon emitted to the environment. This removal action was performed with the approval of USEPA. The clay layer essentially acts as a filter. As a result. lower concentrations of radon are observed in the silo headspace than were observed before the bentonite addition. Concentrations that were initially estimated at 25 to 30 million $\mathrm{pCi} / \mathrm{L}$ were recently observed at less than 4 million $\mathrm{pCi} / \mathrm{L}$. This value is slightly higher than previously recorded values observed since the bentonite addition, and it appears to be rising slightly. Efforts to validate the data obtained thus far are scheduled for 1994.

The next chapter discusses the procedures and practices at the Fernald site that are used to ensure that environmental monitoring data are accurate representations of the conditions at the site. 


\section{Quality Assurance for the Environmental Monitoring Program}

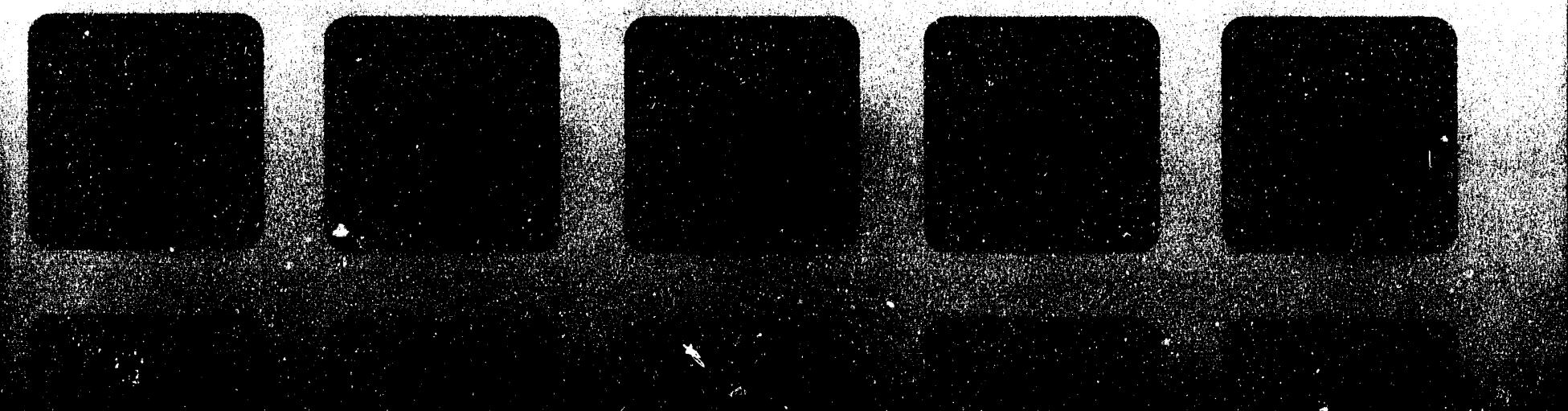




\section{Quality Assurance for the Environmental Monitoring Program}

Acquiring data of known quality is essential to environmental sampling and analysis. Because decisions are made and regulatory compliance is derived from environmental data, the Fernald site has developed comprehensive procedures that define how environmental sampling and analysis are to be conducted. These procedures generate consistency between programs and ensure that USEPA, DOE, or industry-accepted practices and standards for conducting environmental sampling and analysis are used. Quality Assurance (OA) provides the guidelines necessary to monitor the performance of these procedures in a controlled and consistent manner.

Adherence to $\mathrm{OA}$ requirements generates confidence that environmental data are reliable. The $Q A$ process identifies the variability in data, establishes the objectives, and defines the level of confidence needed to meet the objectives. The consistency and precision of sampling and field analysis are measured using $O A$. In the laboratory, $Q A$ measures the accuracy and precision of the analyst and analytical procedures used.

\section{Results in Brief: 1993 Quality Assurance}

DOE's Environmental Measurements Laboratory (EML) Evaluation - Soil and air analyses of the DOE EML samples were shown to be within acceptable limits.

USEPA's Discharge Monitoring Report - All but one of the Fernald site analyses of USEPA wastewater samples were within acceptable limits.

Proficiency Environmental Testing (PET) - Ci the 477 PET samples analyzed, $96 \%$ were within acceptable limits. 


\section{Sitewide CERCLA Quality Assurance Project Plan}

USEPA requires that environmental sampling and analysis activities that they mandate or support contain a centrally managed QA program. Since the Fernald site generates data under CERCLA, it is required to implement procedures that ensure precision, accuracy, completeness, and representativeness of the entire program.

Collection and analysis of environmental samples are integral parts of fulfilling the site's mission and complying with environmental regulations. A single sample of a specific item from a specific location may provide information for a number of remedial investigation, restoration, waste management, and regulatory uses. Therefore, it is necessary that environmental sampling and analysis be conducted in a consistent manner. This will result in usable, valid data of known quality so that use across programs is possible and the level of uncertainty associated with such data is known.

The Sitewide CERCLA Quality Assurance Project Plan (SCQ) was developed for environmental sampling and analysis activities. It established minimum standards of performance for operational and analytical activities, while ensuring that these standards are followed by all programs. Implementation of the SCQ is scheduled to be completed in 1994 at the Fernald site.

\section{Data Quality Objectives}

Prior to sample collection, the Data Quality Objective (DQO) process begins. The DQO process provides a means for the decision maker and the technical team to define the level of quality needed in the data to support a decision. The regulatory requirements are identified and the sampling and analysis plans are designed before the samples are generated. In designing the sampling and analysis plans, the variables established through the DQO process are used to determine the number of samples needed, including QA samples, and to ensure that the total level of uncertainty from sampling and analysis is acceptable. 


\section{Quality Assurance: Field Activities}

QA on field activities is an important part of the environmental monitoring process. The site's environmental monitoring procedures contain detailed QA measures for meeting the criteria established in the DQOs. Only trained personnel who have demonstrated proficiency in making field measurements and collecting representative samples are permitted to perform these functions. Examples of field activities follow.

\section{Field Analysis}

Field measurements offer benefits in time and cost. The measurements provide immediate results on environmental conditions, ensuring that the site maintains compliance with certain parameters. Measurements are made with instruments calibrated against known standards and according to accepted methods. QA measures for instruments include routine performance checks, maintenance, and calibration to help ensure proper operation and accurate lield measurements.

\section{Field Documentation}

Technicians must accurately and systematically record results of field measurements and information pertinent to sample collection for subsequent evaluation and reference. Procedures direct the environmental sampling process from before collection begins $t o$ delivery to the laboratory. In field logbooks, technicians record events and observations such as weather, location, time of sampling, and any unusual events that may influence the sample. Signing and dating all documents helps ensure the traceability and accountability of results when needed in the future.

\section{Field QA/Representative Sampling}

Environmental samples that field technicians collect must be representative of actual conditions in the environment. As such, the site designs sampling programs to reduce sample degradation, sampling variability, and cross-contamination.

The Fernald site takes precautions to prevent changing of sample constituents by purchasing certified clean sample containers and using sample preservatives when needed. Such precautions are necessary to prevent changes that can occur in some samples due to biodegradation from microorganisms, the loss of volatile compounds with increasing temperature, or the loss of trace metals from solution by adsorption onto sample container walls. Refrigeration, or icing, and the addition of chemical preservatives ( such as nitric or sulfuric acid) are used to decrease volatility of organic compounds, control biological and chemical changes, and maintain trace metals in solution.

The use of standardized procedures reduces sampling variability. These procedures ensure consistency from one collection to another. Sampling variability is measured by taking multiple samples of the same type. The precision of the site's sample 
collection and laboratory reproducibility is demonstrated when the analysis results for the duplicate samples are within acceptable limits.

When conducting duplicate sampling, a technician collects two samples from the same location. The samples are then submitted to the same laboratory or submitted to separate laboratories as a means of assessing the precision of the analysis.

The quality of the sample collection process is also evaluated by means of field and equipment blanks. These sample blanks provide valuable data and provide a means of monitoring the sampling process for cross-contamination. The blanks are transported along with the sample containers being taken by the sampling team into the field. When sampling is complete, the blanks are submitted along with the field samples for laboratory analyses. A brief description of different types of blanks follows.

Trip blanks are prepared by filling sample containers with de-ionized water. Anything that will he added to the samples to preserve them after collection is also added to the blanks. The containers are then sealed with tamper-proof tape and transported to the sampling location along with the empty sample containers. The analytical results of the trip blanks detect contamination of samples from empty sample containers and preservatives. Trip blanks are also used to determine the sensitivity of analytical equipment. The result from a trip blank is subtracted from the rest of the samples to obtain a result that has not been influenced by the sensitivity of the equipment used to analyze the sample.

Field blanks are prepared in the laboratory or in the field by filling sample containers witi de-ionized water. Unlike trip blanks, field blanks are not sealed until after all samples have been collected. The container is opened and exposed to the air while other samples are being collected. Results from the field blanks determine if airborne contamination may have entered the field samples during the collection process.

Equipment rinsate blanks consist of a composite of de-ionized water that has been used for a final rinse ini cleaning sampling equipment. Results of equipment rinsate blanks are used to evaluate whether or not sampling equipment was free of contamination before being used to collect additional samples.

\section{Sample Custody}

Most environmental samples must be managed according to USEPA protocols. One such protocol is referred to as chain-of-custody. The custody procedure provides requirements for maintaining sample custody by approved personnel. A sample container and sample must be under custody at all times through final disposition. All samples are obtained and documented according to the chain-of-custody procedure. All personnel relinquishing and receiving custody of samples are required to sign, date, and note the time on a chain-of-custody record. This practice is done so that the sample integrity is maintained and all data are legally defensible. 


\section{Analytical Laboratory Quality Assurance}

The Fernald site uses a variety of procedures to ensure that the laboratories analyzing its samples obtain reliable results. These procedures typically begin with the receipt of samples from the field technicians. Laboratory QA is designed to:

- Ensure use of appropriate measuring equipment,

- Ensure use of approved analytical methods,

- Evaluate analytical performance systematically and objectively,

- Detect and prevent the use of questionable data, and

- Identify appropriate corrective actions.

\section{Analytical Methods}

Many of the analytical methods used at the Fernald site are stipulated by federal laws and regulations. From time to time, modifications to these methods are needed to adjust for matrix effects or other interferences. In addition, other methods, primarily those used in radiological analyses, have not been established as standard USEPA methods. As part of QA, periodic review of the procedures verifies that the appropriate procedures are being used and procedure changes have been approved.

\section{Analytical Performance}

QA sample analyses provide a day-to-day evaluation of the performance of the site laboratory as well as the contract laboratories. This evaluation is conducted by laboratories analyzing National Institute of Standards and Technology reference materials, USEPA radionuclide solutions, standardized reference solutions, spiked samples (samples to which known amounts of contaminants have been added), blank samples, and external proficiency samples. In addition, the site prepares duplicate samples and submits them to the laboratories conducting the analyses. At least $10 \%$ of the total number of samples analyzed are duplicate samples that are processed along with the field samples.

The Fernald site evaluates the QA sample results and regularly submits reports to the laboratories to identify potential areas of concern. In addition to analyzing QA samples, all laboratories perform daily instrument calibrations, stability checks, and reagent checks to monitor for laboratory interference.

Procedural performance is also monitored through sample and matrix spikes. Using these spikes, laboratories determine the percent recoveries of known amounts of analytes that were added to the samples. In addition, matrix interferences can be identified and the accuracy of the analytical procedures can be established. 


\section{Detection of Data Problems and Corrective Action}

As part of the QA program, internal and external groups perform surveillances on laboratory operations. Successful completion of on-the-job training and test sample performances are required for all new analysts, and routine performance checks assess their ability to correctly perform the analytical procedures. The accuracy of the analytical method is measured by the results of $Q A$ samples. If a problem is indicated, the QA department notilies the laboratory so that corrective actions can be taken and suspect results can be evaluated and qualified. As a means of managing variations that occur in the analytical and data generation process, deviations are recorded on Corrective Action Reports. These reports are issued to the responsible manager and can be used as a means to track improvements in the quality system.

\section{Independent Evaluations of the Fernald Site Laboratories}

In addition to the comprehensive internal QA program, onsite laboratories regularly take part in several QA programs conducted by independent organizations. Participation in these external QA programs provides unbiased evaluations of the onsite laboratory performance and generates added confidence that results obtained for environmental samples are reliable.

External QA evaluations are conducted in the following manner. The organization conducting the evaluation prepares QA samples to which known amounts of a chemical or radioactive components are added. The samples, but not the known values of the test components, are distributed to the participating laboratories that analyze the samples and return the results. The organization administering the program then provides a performance evaluation report comparing the laboratories' results to the true values of the test components. In most cases, the report compares the results obtained by the other participating laboratories. These comparisons show whether the laboratories' analyses are within acceptable limits of accuacy or if improvements are required. The various programs are described below.

\section{DOE's Environmental Measurements Laboratory}

The Environmental Measurements Laboratory (EML) Program evaluates the performance of laboratories carrying out radionuclide analyses on environmental samples. Routinely, the Fernald site receives and analyzes air filters and soil samples for uranium and submits results for comparison with other laboratories in the program. In making the comparison, DOE computes a ratio by dividing the site's result by the EML result for each analyte. The ratio equals 1.0() when the results agree exactly. Results within $50 \%$ (ratios greater than $(0.50)$ are considered acceptable.

The ratios for samples analyzed for uranium during 1993 are listed in Table 23 on page A.-41. The result for the 1993 soil sample was within acceptable limits since the 
ratio of the result was 0.64 . The 1993 air filter sample ratio wats 0.91 which is also acceptable. The Fernald site has established requirements for all of its contract laboratories to participate in the EML program and their results must he within $50 \%$ of the EML results.

\section{USEPA's Discharge Monitoring Report}

USEPA requires all laboratories that perform NPDES permit wastewitter analyses to participate in the Discharge Monitoring Report (DMR) QA program. The DMR QA evaluations of the Fernald site laboratories' performance began in 1985. This program evaluates the ability of laboratories to measure nonradioactive contaminants in wastewater. As directed by USEPA, a corresponding QA sample must be analyzed for each parameter listed in the NPDES permit. The NPDES permit parameters that are measured by the Fernald site laboratories are discussed in Chapter Five under "NPIDES Summary for 1993." USEPA evaluates the results for the QA samples as acceptable or unacceptable.

Results obtained by the Fernald site laboratories for the 1993 DMR QA samples are summarized in Table 24 on page A-42. All but one of the site results submitted during 1993 for DMR QA were determined to be acceptable by USEPA. The analysis designated as unacceptable was for lead. An investigation was conducted to determine the cause of the problem, but no apparent cause was found. This should not cause a problem in the future since USEPA has approved a modification of the permit to no longer specify lead as a monitored pollutant under the NPDES permit as of May 20, 1993.

\section{Commercial Proficiency Environmental Testing}

The Fernald site laboratories also participate in the Proficiency Environmental Testing (PET) QA program. This is a voluntary program administered by a commercial vendor of analytical laboratory QA services. Each laboratory pays a fee to participate. Periodically, the Fernald site submits PET samples to the various onsite laboratories concurrently with field samples. Results obtained from these QA samples are compiled and submitted for evaluation by the commercial vendor. A monthly evaluation report is then provided by the vendor comparing the Fernald site laboratories' results to the reference values for each sample and to the results obtained by other laboratories participating in the PET program. By using this commercial service, the site has an additional resource for evaluating its laboratory performance.

A summary of the performance of the site laboratories in the PET QA program during 1993 is provided in Table 25 on pages A-43 and A-44. For the 27 parameters reported, $96 \%$ of the results met acceptable criteria. The PET program does not specify criteria for overall evaluation of a laboratory; however, $96 \%$ shows a good performance, consistent with $96 \%$ in 1992 . 


\section{Ohio Department of Health Split Samples}

Another enhancement to the Fernald site QA program is the Ohio Department of Health (ODH) Split Water and Milk Program. The site has participated in this program with the state since 1987. As the split sample program compares results of samples collected directly from the environment, the true variability in analysis between laboratories is measured.

This program is very similar to the duplicate sample program described above. Although the sampling is similar, the duplicate samples may measure a single laboratory's precision, whereas the $\mathrm{ODH}$ split program measures proficiency between two laboratories.

To obtain split samples, technicians alternately add a portion of the sample being collected to their individual sample containers. This collection method helps ensure that both samples are as identical as possible. Split samples are then submitted to two independent laboratories for analysis.

The site did not receive results for ODH samples collected during 1992 in time to be included in the 1992 SER, so they are presented in this report (see Table 26 on pages A-45 through A-47). Also, the results for the 1993 ODH split samples were not received in time for inclusion in the 1993 report but will be presented in next year's report.

\section{Contract Laboratory Quality Assurance}

Because of the great number of analyses required to support all its various environmental sampling and analyses programs, the site uses commercial laboratories to supplement its onsite analytical laboratories. Commercial laboratories must meet stringent requirements before being selected to provide environmental analytical services. Commercial laboratories, in many cases, must also be certified and have licenses from the state. To select the best qualified laboratory, experienced auditors conduct comprehensive reviews of the laboratory's management, operations, and performance. These reviews are conducted before and also during the service life of the contract. Topics typically reviewed during the audits are:

- Analytical equipment:

- Analytical procedures;

- Personnel qualifications;

- Sample handling and preservation;

- Data evaluation and record keeping; and

- Requirements for precision, accuracy, and detection levels. 
Auditors also review results obtained in independent QA programs as part of the evaluation of each candidate laboratory's analytical capabilities. Onsite audits of the laboratories' facilities and operations are then conducted by Sampling and Analysis Management, Procurement, and QA personnel before final selections are made. After selecting the laboratories, QA samples are submitted regularly with field samples in order to evaluate the contract laboratories' performance on a continuing basis.

As part of the ongoing activities for evaluating the performance of contract laboratories, the site regularly submits QA samples along with field samples to the laboratory that analyzes offsite air filter samples. Nine QA air filter samples, prepared with amounts of uranium known only to the site, were submitted to the laboratory with 1993 field samples. The known amounts of uranium on the QA filters were in the range of the amounts normally present in field samples. The percent recovery of the analyses ranged from 63 to $105 \%$. All the results were in the acceptable range for spiked samples (50) to $150 \%$ ).

The Fernald site employed the same QA measures to evaluate the contract laboratory's analysis of uranium in milk samples. Spiked sample recoveries measure the accuracy of the analyses. Figure 52 shows the percent recovery for the milk QA spike samples sent to the contract laboratory used for all 1993 milk samples (data also inciuded in Table 8 on page A-12). The values ranged from 59 to $131 \%$ with an average of $94 \%$. All these recoveries were within the acceptable range and much improved from the range obtained in 1992 (1 to 233\%).

Figure 52: Milk/Uranium OA Samples, 1993

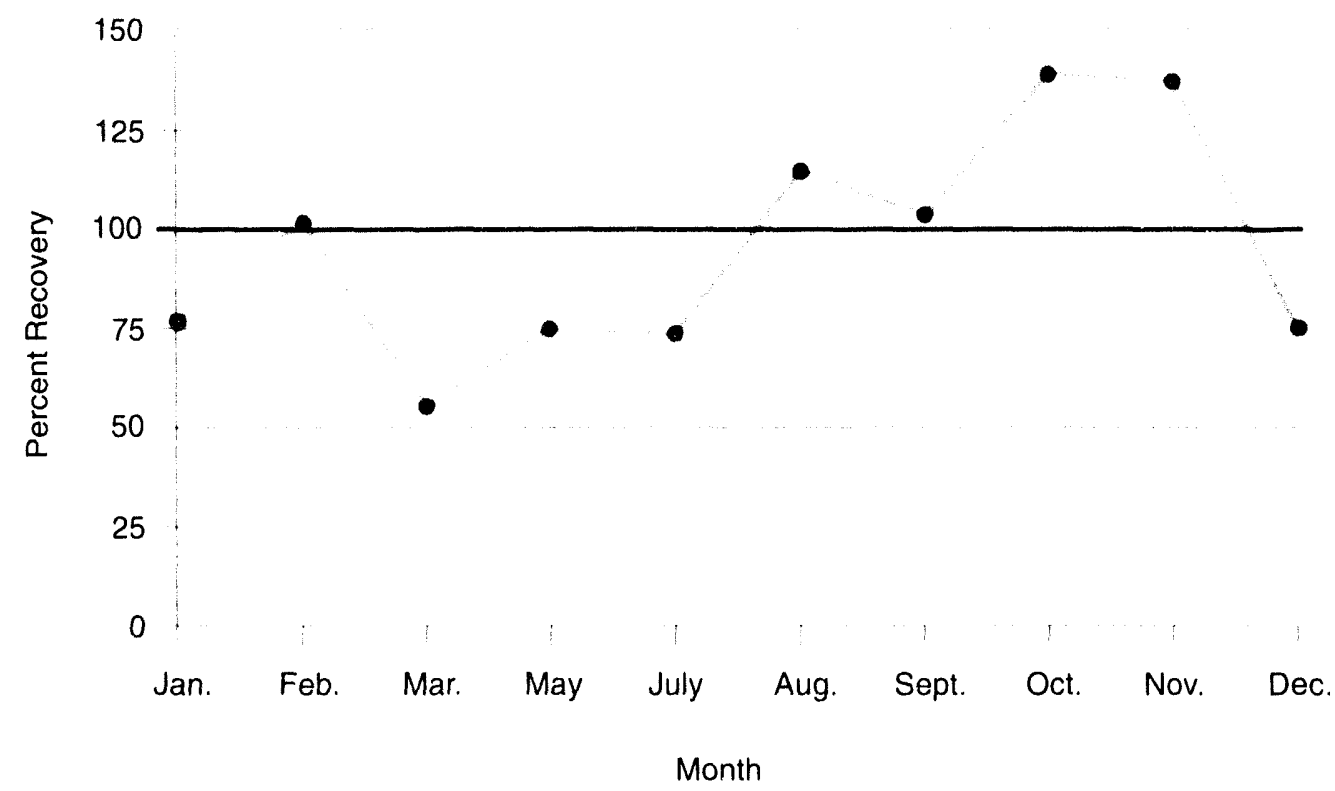




\section{Appendices}

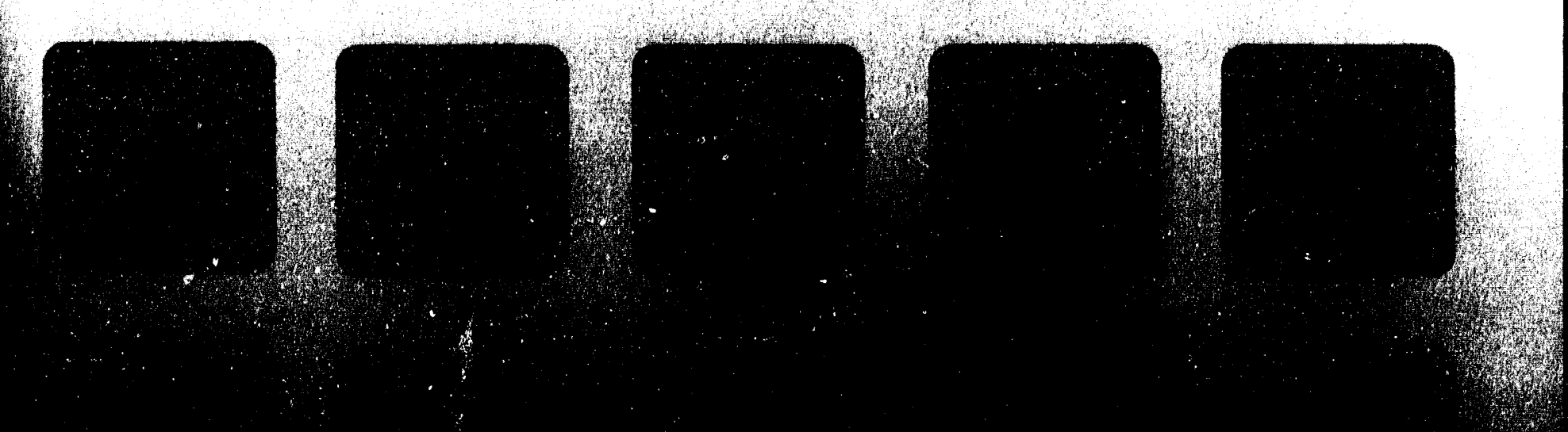




\section{Fernald Site Environmental Monitoring Data for 1993}

Numerous sampling and analysis data are required to evaluate compliance with environmental regulations and to obtain accurate indications of the Fernald site's operations during 1993. The sampling and analysis results are provided in summary tables.

Many of the numerical values listed in the following data tables are preceded by the "less than" symbol $(<)$. The less than symbol is used when the concentration of a chemical species (ion, molecule, compound, or radionuclide) in an environmental media (air, water, or sediment) could not be reliably measured in the sample which was analyzed. That is, the amount of the species, if present at all in the sample, was below the minimum measurable concentration. Thus, a value of $<0.68 \mathrm{pCi} / \mathrm{L}$ listed as the concentration of uranium in milk means that the uranium concentration was less than 0.68 $\mathrm{pCi} / \mathrm{L}$ but actually could have been anywhere from 0.00 to $0.67 \mathrm{pCi} / \mathrm{L}$.

The minimum measurable concentration is not the same for all chemical species. For example, $0.25 \mathrm{pCi} / \mathrm{g}$ of radium-226 and $0.21 \mathrm{pCi} / \mathrm{g}$ of plutonium238 are the approximate minimum measurable concentrations for sediment samples. These variations exist because of differences in chemical and physical properties of species in addition to differences in the capabilities of instruments available to measure these properties.

Also, the minimum measurable concentration is not always the same for a specific species in all samples of the same environmental media. That is, the minimum measurable concentration for uranium in groundwater samples may vary for water samples from two different locations. This is so because variations in the kinds or amounts of other substances in the two samples can influence how well a substance can be measured.

In addition, the minimum measurable concentration of a species will not always be the same for identical samples from the same location which are analyzed at different times. This variance occurs because of unavoidable minor fluctuations in the performance of analytical instrumentation used to perform sample measurements.

Negative results incicate that the radionuclide activity in the sample was less than the background activity within the measurement laboratory. A negative value is obtained by subt. acting the laboratory background measurement from the sample measurement. Negative results are not actual concentrations but are useful in the statistical analysis of data. 
TABLE 1: Meteorological Data, 1993

\begin{tabular}{|c|c|c|c|c|c|c|c|c|c|c|c|c|c|}
\hline & Units & January & February & March & April & May & June & July & August & September & October & November & December \\
\hline \multicolumn{14}{|c|}{$10-$ Meter Wind Speed } \\
\hline $\begin{array}{l}\text { Maximum } \\
\text { hourly average }\end{array}$ & $\operatorname{kph}(\mathrm{a})$ & 20 & 19 & 36 & 27 & 19 & 16 & 15 & 15 & 18 & 19 & 20 & 24 \\
\hline $\begin{array}{l}\text { Minimum } \\
\text { hourly average }\end{array}$ & $\operatorname{kph}(\mathrm{a})$ & 0.51 & 0.72 & 0.21 & 0.74 & 0.60 & 0.31 & 0.51 & 0.43 & 0.14 & 0.05 & 0.31 & 0.02 \\
\hline \multicolumn{14}{|c|}{60 - Meter Wind Speed } \\
\hline $\begin{array}{l}\text { Maximum } \\
\text { hourly average }\end{array}$ & $\mathrm{kph}(\mathrm{a})$ & 39 & 39 & 51 & 44 & 30 & 32 & 27 & 24 & 36 & 36 & 34 & 34 \\
\hline $\begin{array}{l}\text { Minimum } \\
\text { hourly average }\end{array}$ & $\operatorname{kph}(a)$ & 0.80 & 1.7 & 2.5 & 1.2 & 0.95 & 0.82 & 1.3 & 0.56 & 0.80 & 0.02 & 0.21 & 0.80 \\
\hline \multicolumn{14}{|c|}{ Ambient Air Temperature ${ }^{(b)}$} \\
\hline Average & ${ }^{\circ} \mathrm{C}$ & 1.2 & -2.0 & 4.3 & 11 & 17 & 21 & 25 & 23 & 17 & 11 & 6.2 & 0.77 \\
\hline Maximum & $\mathrm{C}$ & 16 & 18 & 20 & 25 & 30 & 32 & 35 & 33 & 30 & 27 & 20 & 13 \\
\hline Minimum & $\mathrm{C}$ & -11 & -19 & -13 & -0.29 & 5.0 & 5.5 & 10 & 11 & -0.52 & -1.7 & -5.7 & -16 \\
\hline \multicolumn{14}{|l|}{ Dew Point (b) } \\
\hline Average & $\mathrm{C}$ & (c) & (c) & (c) & (c) & $8.5^{(\mathrm{d})}$ & 15 (d) & 18 (d) & 17 & $12^{(d)}$ & 4.3 & $0.5^{\text {(d) }}$ & (c) \\
\hline Maximum & $\mathrm{C}$ & (c) & (c) & (c) & (c) & 18 & 21 & 24 & 23 & 21 & 17 & 15 & (c) \\
\hline Minimum & ${ }^{\circ} \mathrm{C}$ & (c) & (c) & (c) & (c) & -0.38 & 0.85 & 8.6 & 6.0 & -2.0 & -6.4 & -10 & (c) \\
\hline \multicolumn{14}{|l|}{ Precipitation } \\
\hline Monthly Total & $a m(e)$ & 10 & 7.5 & 6.5 & 10 & 7.6 & 14 & 4.5 & 7.2 & 7.7 & 7.6 & 10 & 4.9 \\
\hline Daily Maximum & $a m(e)$ & 3.9 & 2.1 & 1.9 & 2.8 & 3.0 & 7.5 & 1.6 & 3.7 & 2.5 & 2.4 & 3.0 & 2.1 \\
\hline
\end{tabular}

(a) To obtain wind speeds in miles per hour, divile by 1.6093.

(b) Ambierit air temperature is measured at the 10-meter (33-foot) !evel. To obtain F. multiply $\mathrm{C}$ by 9 , divide by 5 , and add 32 .

(c) Data not available due to sensor problems.

(d) Only partial data are available for calculations.

(e) To obtain precipitation amounts in inches, divide by 2.54 . 
TABLE 2: Estimated Population Distribution within

$80 \mathrm{~km}$ (50 miles) of the Fernald Site, 1993 (a)

\begin{tabular}{|c|c|c|c|c|c|c|c|c|c|c|}
\hline $\begin{array}{c}\text { Compass } \\
\text { Sector }\end{array}$ & $\begin{array}{c}0-1.6 \mathrm{~km} \\
(0-1 \text { mile })\end{array}$ & $\begin{array}{l}1.6-3.2 \mathrm{~km} \\
(1-2 \text { miles })\end{array}$ & $\begin{array}{l}3.2-4.8 \mathrm{~km} \\
(2-3 \text { miles })\end{array}$ & $\begin{array}{l}4.8-6.4 \mathrm{~km} \\
(3-4 \text { miles })\end{array}$ & $\begin{array}{c}6.4-8 \mathrm{~km} \\
(4-5 \text { miles })\end{array}$ & $\begin{array}{c}8-16 \mathrm{~km} \\
(5-10 \text { miles })\end{array}$ & $\begin{array}{c}16-32 \mathrm{~km} \\
(10-20 \text { miles })\end{array}$ & $\begin{array}{c}32-48 \mathrm{~km} \\
(20-30 \text { miles })\end{array}$ & $\begin{array}{c}48-64 \mathrm{~km} \\
(30-40 \text { miles })\end{array}$ & $\begin{array}{c}64-80 \mathrm{~km} \\
(40-50 \text { miles })\end{array}$ \\
\hline$N$ & 2 & 54 & 193 & 20 & 140 & 2,157 & 15,117 & 7,201 & 16,590 & 13,291 \\
\hline NNE & 0 & 71 & 51 & 113 & 147 & 12,263 & 8,174 & 9,742 & 30,568 & 86,398 \\
\hline $\mathrm{NE}$ & 2 & 202 & 827 & 97 & 90 & 34,292 & 38,797 & 88,477 & 214,495 & 331,340 \\
\hline ENE & 5 & 87 & 1,766 & 219 & 13 & 31,999 & 32,998 & 32,039 & 14,739 & 29,771 \\
\hline$E$ & 3 & 3 & 179 & 301 & 248 & 38.285 & 75,213 & 50,799 & 17,863 & 10,218 \\
\hline ESE & 8 & 54 & 78 & 558 & 739 & 42,893 & 160,628 & 68,672 & 22,433 & 13,541 \\
\hline SE & 10 & 200 & 52 & 394 & 680 & 53,789 & 271,217 & 96,398 & 28,351 & 11,194 \\
\hline SSE & 6 & 349 & 165 & 217 & 492 & 21,506 & 226,652 & 58.844 & 12,567 & 8,122 \\
\hline $\mathrm{S}$ & 3 & 7 & 17 & 253 & 538 & 9,177 & 32,980 & 38,030 & 8,392 & 9,825 \\
\hline SSW & 3 & 27 & 205 & 40 & 188 & 5,638 & 8,999 & 7,630 & 5,390 & 10,277 \\
\hline SW & 2 & 37 & 26 & 355 & 60 & 4,486 & 14,209 & 9,197 & 3,523 & 4,341 \\
\hline WSW & 0 & 15 & 40 & 511 & 313 & 8,540 & 5,255 & 7,725 & 7,556 & 4,681 \\
\hline W & 6 & 13 & 37 & 286 & 596 & 1,664 & 3,547 & 10,295 & 5,357 & 15,708 \\
\hline WNW & 5 & 20 & 60 & 123 & 121 & 1,093 & 4,675 & 4,205 & 5,714 & 11,295 \\
\hline NW & 1 & 18 & 261 & 269 & 254 & 1,196 & 1,423 & 3,757 & 22,376 & 8,795 \\
\hline NNW & 2 & 7 & 97 & 312 & 722 & 1,239 & 12,713 & 5,128 & 48,409 & 15,256 \\
\hline Total & 58 & 1,164 & 4,054 & 4,068 & 5,341 & 270,217 & 912,597 & 498,139 & 464,323 & 584,053 \\
\hline
\end{tabular}

(a) Based on an extrapolation from 1990 census data by Geographic Data Systems Section, Computing and Telecommunications Division at Oak Ridge National Laboratory, April 1992. 
TABLE 3: Uranium in Air, 1993

\begin{tabular}{|c|c|c|c|c|c|c|c|}
\hline \multirow{2}{*}{$\begin{array}{c}\text { Sampling (a) } \\
\text { Location }\end{array}$} & \multirow{2}{*}{$\begin{array}{c}\text { Number } \\
\text { of Samples }\end{array}$} & \multicolumn{3}{|c|}{ Concentration $\left(\mathrm{pCi} / \mathrm{m}^{3} \times 10^{-6}\right)(\mathrm{b})$} & \multicolumn{3}{|c|}{ Percent of Standard(c) } \\
\hline & & Minimum & Maximum & Average & Minimum & Maximum & Average \\
\hline \multicolumn{8}{|l|}{ Fenceline } \\
\hline AMS 1 & 28 & -30 & 3,600 & 490 & 0.0 & 3.6 & 0.49 \\
\hline AMS 2 & 52 & 0.0 & 710 & 160 & 0.0 & 0.71 & 0.16 \\
\hline AMS 3 & 51 & -60 & 3,300 & 380 & 0.0 & 3.3 & 0.38 \\
\hline AMS 4 & 52 & -20 & 330 & 63 & 0.0 & 0.33 & 0.063 \\
\hline AMS 5 & 52 & -10 & 350 & 73 & 0.0 & 0.35 & 0.073 \\
\hline AMS 6 & 52 & 5 & 190 & 62 & 0.005 & 0.19 & 0.062 \\
\hline AMS 7 & 52 & -30 & 310 & 49 & 0.0 & 0.31 & 0.049 \\
\hline \multicolumn{8}{|l|}{ Onsite } \\
\hline AMS $1 \mathrm{~A}$ & 25 & 64 & 4,100 & 1,100 & 0.064 & 4.1 & 1.1 \\
\hline AMS 8 & 51 & 43 & 4,100 & 650 & 0.043 & 4.1 & 0.65 \\
\hline AMS 9 & 51 & 100 & 17,000 & 1,600 & 0.10 & 17 & 1.6 \\
\hline \multicolumn{8}{|c|}{ Waste Pit Area } \\
\hline AMS 17 & 52 & -26 & 1,100 & 140 & 0.0 & 1.1 & 0.14 \\
\hline AMS 18 & 52 & 0.0 & 3,900 & 930 & 0.0 & 3.9 & 0.93 \\
\hline AMS 19 & 52 & -47 & 410 & 97 & 0.0 & 0.41 & 0.097 \\
\hline AMS 20 & 52 & -38 & 730 & 150 & 0.0 & 0.73 & 0.15 \\
\hline \multicolumn{8}{|l|}{ Offsite } \\
\hline AMS 10 & 52 & -30 & 55 & 19 & 0.0 & 0.055 & 0.019 \\
\hline AMS 11 & 52 & -30 & 54 & 17 & 0.0 & 0.054 & 0.0 .7 \\
\hline AMS 12 & 52 & -40 & 51 & 12 & 0.0 & 0.051 & 0.012 \\
\hline AMS 13 & 52 & -30 & 180 & 26 & 0.0 & 0.18 & 0.026 \\
\hline AMS 14 & 52 & -30 & 58 & 22 & 0.0 & 0.058 & 0.022 \\
\hline AMS 15 & 52 & -20 & 59 & 25 & 0.0 & 0.059 & 0.025 \\
\hline AMS 16 & 52 & -30 & 78 & 25 & 0.0 & 0.078 & 0.025 \\
\hline
\end{tabular}

(a) See Figure 21 on page 68 for locations.

(b) The amount of uranium in each sample is chemically determined and converted to units of activity using the conversion constant of 0.68 $\mathrm{pCi} / \mu \mathrm{g}$ (natural uranium). Negative results indicate that the amount of uranium in the sample was less than the amount of uranium measured in a blank filter.

(c) Standard is $100,000 \times 10^{-6} \mathrm{pCi} / \mathrm{m}^{3}$, as listed in DOE Order 5400.5 , "Radiation Protection of the Public and Environment." 


\begin{tabular}{|c|c|c|c|c|c|}
\hline \multicolumn{6}{|c|}{ Concentration ${ }^{(a)}\left(\mathrm{pCi} / \mathrm{m}^{3} \times 10^{-6}\right)$} \\
\hline $\begin{array}{c}\text { Sampling } \\
\text { Location(b) }\end{array}$ & Strontium-90 & Technetium-99 & Cesium-137 & Radium-226 & Radium-228 \\
\hline AMS 2 & $<5.1$ & $<6.6$ & $<20$ & $<2.1$ & $<78$ \\
\hline AMS 3 & $<6.4$ & $<94$ & $<24$ & $<1.9$ & $<98$ \\
\hline AMS 4 & $<5.1$ & $<76$ & $<19$ & $15 \pm 7.1$ & $<75$ \\
\hline AMS 5 & $<5.1$ & $<69$ & $<18$ & $19 \pm 7.4$ & $<55$ \\
\hline AMS 6 & $<5.1$ & $<73$ & $<18$ & $7.4 \pm 5.7$ & $<70$ \\
\hline AMS 7 & $<5.1$ & $<64$ & $<20$ & $54 \pm 11$ & $<58$ \\
\hline AMS 8 & $39 \pm 12$ & $670 \pm 120$ & $<21$ & $19 \pm 6.9$ & $<85$ \\
\hline AMS 9 & $11 \pm 3.5$ & $76 \pm 13$ & $<23$ & $35 \pm 9.3$ & $<87$ \\
\hline AMS 10 & $<4$ & $53 \pm 13$ & $<16$ & $650 \pm 95$ & $<63$ \\
\hline AMS 11 & $<4$ & $<20$ & $<13$ & $130 \pm 23$ & $70 \pm 40$ \\
\hline AMS 12 & $22 \pm 6.5$ & $<30$ & $<15$ & $210 \pm 30$ & $<60$ \\
\hline AMS 13 & $<4$ & $<38$ & $<15$ & $220 \pm 35$ & $85 \pm 48$ \\
\hline AMS 14 & $<4$ & $<28$ & $<15$ & $220 \pm 28$ & $<60$ \\
\hline AMS 15 & $14 \pm 4.5$ & $<28$ & $500 \pm 45$ & $80 \pm 14$ & $75 \pm 30$ \\
\hline AMS 16 & $13 \pm 4.0$ & $<25$ & $<15$ & $17 \pm 4.3$ & $78 \pm 43$ \\
\hline $\mathrm{DCG}^{(\mathrm{c})}$ & $9,000,000$ & $2,000,000,000$ & $400,000,000$ & $1,000.000$ & $3,000,000$ \\
\hline
\end{tabular}


TABLE 4: Radionuclides in Air, 1993

\begin{tabular}{|c|c|c|c|c|c|}
\hline \multicolumn{6}{|c|}{ Concentration (a) $\left(\mathrm{pCi} / \mathrm{m}^{3} \times 10^{-6}\right)$} \\
\hline $\begin{array}{l}\text { Sampling } \\
\text { Location(b) }\end{array}$ & Thorium-228 & Thorium-230 & Thorium-232 & Neptunium-237 & Plutonium-238 \\
\hline AMS 2 & $<3.9$ & $<6.6$ & $<6.2$ & $<2.2$ & $<0.66$ \\
\hline AMS 3 & $8.8 \pm 12$ & $33 \pm 17$ & $5.9 \pm 10$ & $<2.7$ & $<0.17$ \\
\hline AMS 4 & $<3.4$ & $12 \pm 11$ & $<4.8$ & $<34$ & $<1.7$ \\
\hline AMS 5 & $14 \pm 11$ & $42 \pm 17$ & $7.8 \pm 8.5$ & $<7.0$ & $<3.0$ \\
\hline AMS 6 & $<21$ & $<18$ & $<15$ & $<1.6$ & $0.71 \pm 0.35$ \\
\hline AMS 7 & $<7.8$ & $53 \pm 22$ & $19 \pm 12$ & $<1.6$ & $<8.6$ \\
\hline AMS 8 & $12 \pm 11$ & $27 \pm 14$ & $5.2 \pm 8.0$ & $<2.1$ & $<0.85$ \\
\hline AMS 9 & $10 \pm 11$ & $17 \pm 13$ & $<8.7$ & $<5.5$ & $0.85 \pm 0.76$ \\
\hline AMS 10 & $<8.3$ & $13 \pm 8.5$ & $<5.8$ & $8.5 \pm 6.3$ & $<6$ \\
\hline AMS 11 & $7.8 \pm 2.5$ & $8.3 \pm 2.8$ & $5.0 \pm 2$ & $<1.4$ & $<1.2$ \\
\hline AMS 12 & $<110$ & $<88$ & $<130$ & $<0.5$ & $<0.43$ \\
\hline AMS 13 & $9.8 \pm 3.3$ & $9.3 \pm 3$ & $7.5 \pm 2.5$ & $<1.2$ & $<0.30$ \\
\hline AMS 14 & $53 \pm 24$ & $21 \pm 11$ & $38 \pm 18$ & $0.55 \pm 0.45$ & $<0.17$ \\
\hline AMS 15 & $19 \pm 14$ & $<4.3$ & $<13$ & $<130$ & $<0.11$ \\
\hline AMS 16 & $98 \pm 100$ & $13 \pm 20$ & $<33$ & $<0.3$ & $<0.3$ \\
\hline DCG $(c)$ & 40,000 & 40,000 & 7,000 & 20,000 & 30,000 \\
\hline
\end{tabular}




\begin{tabular}{|c|c|c|c|c|c|}
\hline \multicolumn{6}{|c|}{ Concentration $^{(a)}\left(\mathrm{pCi} / \mathrm{m}^{3} \times 10^{-6}\right)$} \\
\hline $\begin{array}{l}\text { Sampling } \\
\text { Location(b) }\end{array}$ & Plutonium-239/240 & Uranium-234 & Uranium-235(d) & Uranium-236(d) & Uranium-238 \\
\hline AMS 2 & $<0.78$ & $87 \pm 13$ & $3.6 \pm 0.55$ & $2.3 \pm 0.34$ & $75 \pm 11$ \\
\hline AMS 3 & $<0.59$ & $130 \pm 20$ & $5.6 \pm 0.84$ & $3.5 \pm 0.53$ & $120 \pm 17$ \\
\hline AMS 4 & $<6.7$ & $36 \pm 5.4$ & $1.5 \pm 0.23$ & $0.94 \pm 0.14$ & $31 \pm 4.7$ \\
\hline AMS 5 & $<0.70$ & $41 \pm 6.2$ & $1.7 \pm 0.26$ & $1.1 \pm 0.16$ & $36 \pm 5.4$ \\
\hline AMS 6 & $<0.47$ & $35 \pm 5.3$ & $1.5 \pm 0.22$ & $0.91 \pm 0.14$ & $30 \pm 4.5$ \\
\hline AMS 7 & $<0.35$ & $28 \pm 4.2$ & $1.2 \pm 0.18$ & $0.73 \pm 0.11$ & $24 \pm 3.6$ \\
\hline AMS 8 & $<0.93$ & $370 \pm 55$ & $15 \pm 2.3$ & $9.6 \pm 1.4$ & $320 \pm 48$ \\
\hline AMS 9 & $<1.9$ & $870 \pm 130$ & $36 \pm 5.5$ & $23 \pm 3.4$ & $750 \pm 110$ \\
\hline AMS 10 & $<6.0$ & $24 \pm 6$ & 2.0 & \pm 1.1 & $2.2 \pm 5.5$ \\
\hline AMS 11 & $<1.2$ & $24 \pm 6$ & 1.5 & \pm 0.95 & $28 \pm 6.8$ \\
\hline AMS 12 & $<0.17$ & $24 \pm 6$ & 0.98 & \pm 0.78 & $25 \pm 6.3$ \\
\hline AMS 13 & $<0.70$ & $25 \pm 6$ & 1.3 & \pm 0.80 & $28 \pm 6.5$ \\
\hline AMS 14 & $<0.17$ & $30 \pm 8$ & 1.5 & \pm 1.1 & $28 \pm 7.5$ \\
\hline AMS 15 & $0.35 \pm 0.30$ & $30 \pm 7.3$ & 1.6 & \pm 0.95 & $33 \pm 7.8$ \\
\hline AMS 16 & $<1.1$ & $30 \pm 7.5$ & 2.0 & \pm 1.3 & $30 \pm 7.8$ \\
\hline DCG (c) & 20,000 & 90,000 & 100,000 & 100,000 & 100,000 \\
\hline
\end{tabular}

(a) Plus/minus ( \pm ) values are the uncertainty in the analytical results at the $95 \%$ confidence level.

(b) See Figure 21 on page 68 for sampling locations. Results from AMS 1 and AMS 1A were invalidated due to error in sampling and analysis.

(c) Derived concentration guides from DOE Order 5400.5, "Radiation Protection of the Public Environment," February 1990. Continuous inhalation of this concentration will result in a committed effective dose equivalent of $100 \mathrm{mrem}$ ( $1 \mathrm{mSv}$ ).

(d) Concentration of uranium-235 plus uranium-236. Offsite AMS samples analyzed for isotopic uranium by alpha

spectrometry which measures combined uranium-235 and uranium-236 activities; individual measurements of uranium isotopes performed by mass spectrometry on samples from other AMS locations. 
Table 5: Comparison of Measured and Estimated Airborne

Uranium Concentrations at the Fernald Site Fenceline

Uranium Concentration $\left(\mathrm{pCi} / \mathrm{m}^{3} \times 10^{-6}\right)$

\begin{tabular}{|c|c|c|}
\hline Location & Measured(a) & Estimated \\
\hline AMS 2 & 130 & 5.0 \\
\hline AMS 3 & 360 & 7.9 \\
\hline AMS 4 & 40 & 2.3 \\
\hline AMS 5 & 50 & 2.8 \\
\hline AMS 6 & 40 & 3.5 \\
AMS 7 & 20 & 7.3 \\
\hline
\end{tabular}

(a) Corrected for background. 
TABLE 6: Uranium in Grass and Soil, 1993

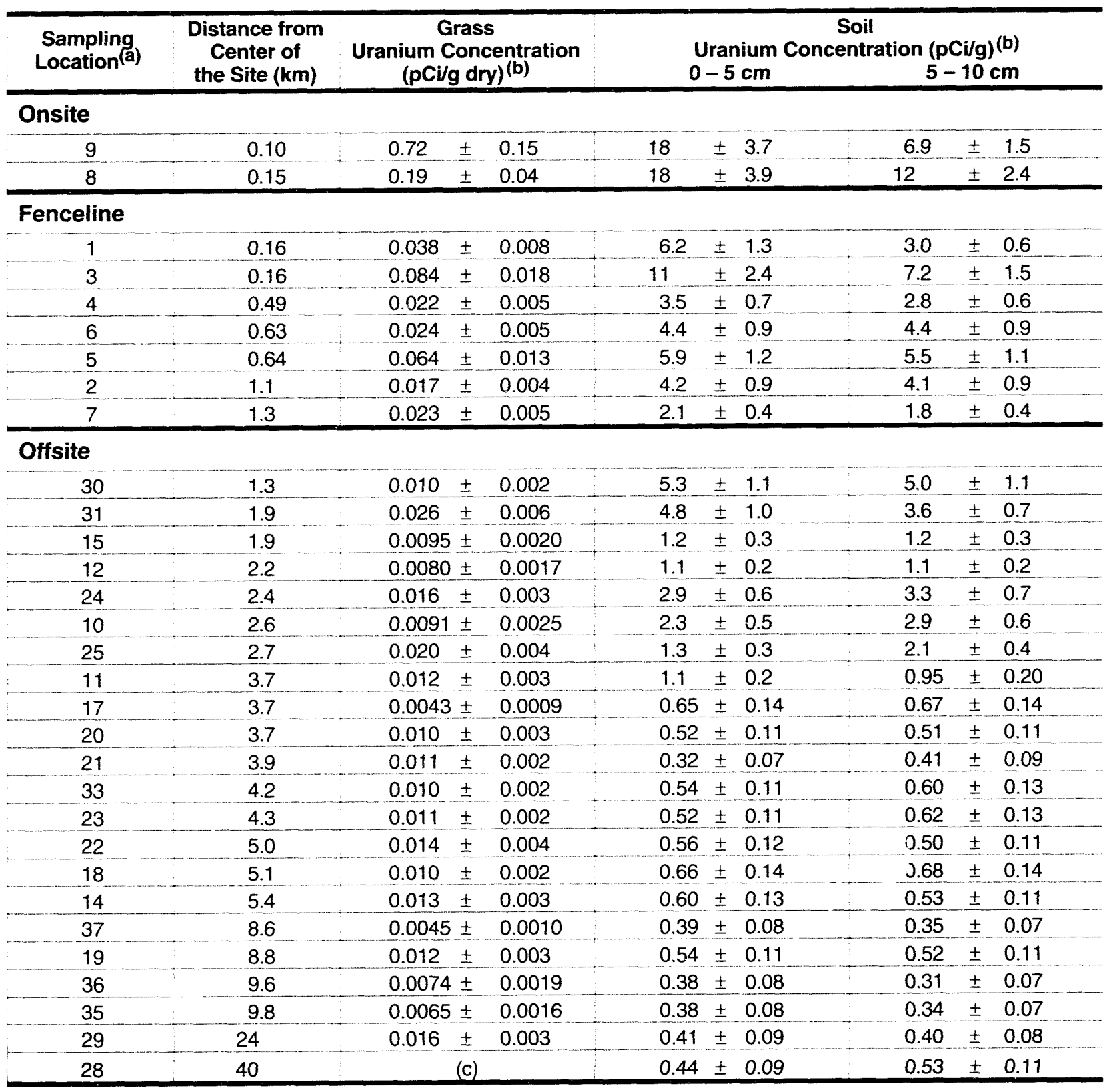

(a) Locations (see Figure 24 on page 73) are listed in order of increasing distance from the center of the Fernald site production area (Plant 4).

(b) To obtain $\mathrm{Bq} / \mathrm{g}$, multiply $\mathrm{pCi} / \mathrm{g}$ by 0.037 The plus/minus $( \pm)$ values are the uncertainty in the analytical results at the $95 \%$ confidence level.

(c) No grass was available to sample. 
TABLE 7: Uranium in Produce and Soil, 1993

\begin{tabular}{|c|c|c|c|c|}
\hline $\begin{array}{l}\begin{array}{c}\text { Sampling } \\
\text { Location }\end{array} \\
\text { Soil }\end{array}$ & $\begin{array}{c}\text { Distance } \\
\text { from Center } \\
\text { of the Site }(\mathbf{k m})\end{array}$ & \multicolumn{3}{|c|}{$\begin{array}{l}\text { Concentration } \\
\text { (pCi/g dry) }^{(b)}\end{array}$} \\
\hline 19 & 1.4 & 0.99 & \pm & 0.10 \\
\hline 14 & 1.6 & 2.0 & \pm & 0.2 \\
\hline 9 & 1.6 & 1.1 & \pm & 0.1 \\
\hline 23 & 1.6 & 1.0 & \pm & 0.01 \\
\hline 23 & 1.6 & 1.2 & \pm & 0.1 \\
\hline 24 & 1.6 & 1.5 & \pm & 0.2 \\
\hline 4 & 1.9 & 1.2 & \pm & 0.1 \\
\hline 18 & 1.9 & 0.87 & \pm & 0.09 \\
\hline 18 & 1.9 & 0.98 & \pm & 0.10 \\
\hline 18 & 1.9 & 0.58 & \pm & 0.06 \\
\hline 18 & 1.9 & 1.4 & \pm & 0.01 \\
\hline 6 & 2.0 & 1.2 & \pm & 0.1 \\
\hline 20 & 2.1 & 1.4 & \pm & 0.2 \\
\hline 15 & 2.4 & 1.8 & \pm & 0.2 \\
\hline 21 & 2.4 & 0.39 & \pm & 0.41 \\
\hline 21 & 2.4 & 0.82 & \pm & 0.09 \\
\hline 26 & 2.6 & 0.59 & \pm & 0.06 \\
\hline 30 & 2.6 & 0.64 & \pm & 0.07 \\
\hline 5 & 2.9 & 0.92 & \pm & 0.10 \\
\hline 12 & 3.6 & 1.2 & \pm & 0.1 \\
\hline 13 & 3.8 & 0.74 & \pm & 0.08 \\
\hline 10 & 4.0 & 0.83 & \pm & 0.09 \\
\hline 7 & 4.9 & 0.68 & \pm & 0.07 \\
\hline 28 & 6.2 & 0.60 & \pm & 0.06 \\
\hline 17 & 16 & 0.52 & \pm & 0.05 \\
\hline 11 & 24 & 0.59 & \pm & 0.06 \\
\hline 16 & 30 & 0.56 & \pm & 0.06 \\
\hline
\end{tabular}

\begin{tabular}{clc}
\hline $\begin{array}{c}\text { Sampling } \\
\text { Location }\end{array}$ & $\begin{array}{c}\text { Concentration } \\
(\mathrm{pCi} / \mathrm{g} \text { dry })\end{array}$ \\
\hline (b)
\end{tabular}

\begin{tabular}{ll}
\hline $\begin{array}{c}\text { Sampling } \\
\text { Location }\end{array}$ & $\begin{array}{l}\text { Concentration } \\
(\mathrm{pCi} / \mathrm{g} \text { dry })^{(\mathrm{b})}\end{array}$ \\
\hline
\end{tabular}

\begin{tabular}{|c|c|c|c|}
\hline \multicolumn{4}{|l|}{ Corn } \\
\hline 19 & 0.000086 & \pm & 0.000011 \\
\hline 14 & 0.00013 & \pm & 0.00001 \\
\hline 23 & 000032 & \pm & 0.000004 \\
\hline 4 & 0.00078 & \pm & 0.00009 \\
\hline 18 & 0.00021 & \pm & 0.00002 \\
\hline 18 & 0.000086 & \pm & 0.000001 \\
\hline 6 & 0.0014 & \pm & 0.0002 \\
\hline 21 & 0.00012 & \pm & 0.00001 \\
\hline 5 & 0.0015 & \pm & 0.0003 \\
\hline 13 & 0.00032 & \pm & 0.00003 \\
\hline 7 & 0.00019 & \pm & 0.00003 \\
\hline 28 & 0.0012 & \pm & 0.0001 \\
\hline 17 & 0.000064 & \pm & 0.000008 \\
\hline
\end{tabular}

\begin{tabular}{|c|c|c|c|}
\hline \multirow{2}{*}{$\begin{array}{r}\text { Green (G) } \\
4(G)\end{array}$} & \multirow{2}{*}{$\begin{array}{r}\text { Red (R) } \\
0.0047\end{array}$} & \multicolumn{2}{|c|}{ Peppers } \\
\hline & & \pm & 0.0005 \\
\hline $4(R)$ & 0.0011 & \pm & 0.0001 \\
\hline $30(\mathrm{G})$ & 0.0049 & \pm & 0.0005 \\
\hline $5(G)$ & 0.0011 & \pm & 0.0001 \\
\hline $5(R)$ & 0.00082 & \pm & 0.00010 \\
\hline $12(\mathrm{G})$ & 0.00078 & \pm & 0.00008 \\
\hline $11(\mathrm{G})$ & 0.0013 & \pm & 0.0001 \\
\hline $16(\mathrm{G})$ & 0.00035 & \pm & 0.00004 \\
\hline
\end{tabular}


TABLE 7: Uranium in Produce and Soil, 1993

\begin{tabular}{c|c}
\hline $\begin{array}{c}\text { Sampling } \\
\text { Location }\end{array}$ & $\begin{array}{c}\text { Concentration } \\
\text { (pCi/g dry) }\end{array}$ \\
\hline Potatoes (P)
\end{tabular}

\begin{tabular}{|c|c|c|}
\hline $\begin{array}{l}\text { Sampling } \\
\text { Location (a) }\end{array}$ & \multicolumn{2}{|c|}{$\begin{array}{l}\text { Concentration } \\
\text { (pCi/g dry) }^{(b)}\end{array}$} \\
\hline \multicolumn{3}{|c|}{ Cucumber (C), Eggplant (E), } \\
\hline \multicolumn{3}{|c|}{ Green Beans (G), \& Squash (S) } \\
\hline $4(C)$ & 0.0054 & \pm 0.0006 \\
\hline $4(S)$ & 0.0053 & \pm 0.0006 \\
\hline $4(S)$ & 0.0065 & \pm 0.0001 \\
\hline $4(E)$ & 0.50094 & \pm 0.00010 \\
\hline $6(B)$ & 0.011 & \pm 0.001 \\
\hline $15(S)$ & 0.0017 & \pm 0.0002 \\
\hline $15(\mathrm{~S})$ & 0.0014 & \pm 0.0002 \\
\hline $30(\mathrm{C})$ & 0.0017 & \pm 0.0002 \\
\hline $5(E)$ & 0.00064 & \pm 0.00007 \\
\hline $10(S)$ & 0.019 & \pm 0.020 \\
\hline $7(S)$ & 0.00027 & \pm 0.00004 \\
\hline $7(S)$ & 0.00036 & \pm 0.00004 \\
\hline $17(\mathrm{C})$ & 0.00026 & \pm 0.00004 \\
\hline $17(\mathrm{~B})$ & 0.0011 & \pm 0.0001 \\
\hline
\end{tabular}

\begin{tabular}{ccc}
$\begin{array}{c}\text { Soybeans } \\
23\end{array}$ & $0.00045 \pm 0.00005$ \\
24 & $0.00030 \pm 0.00001$ \\
\hline 18 & $0.00057 \pm 0.00006$ \\
18 & $0.00093 \pm 0.00001$ \\
20 & $0.00017 \pm 0.00002$ \\
21 & $0.0025 \pm 0.0003$ \\
\hline
\end{tabular}

(a) Locations (see Figure 26 on page 76) are listed in order of increasing distance from the center of the Fernald site production area (Plant 4).

(b) To obtain $\mathrm{Bq} / \mathrm{g}$, multiply $\mathrm{pCi} / \mathrm{g}$ by 0.037 . The plus/minus $( \pm)$ values are the uncertainty in the analytical results at the $95 \%$ confidence level. 
TABLE 8: Uranium in Milk, 1993

$\vec{N} \quad$ Concentration of Uranium

\begin{tabular}{|c|c|c|c|c|}
\hline Month & $\begin{array}{l}\text { Local Dairy } \\
\left(\text { (pCi/L) }^{(a)}\right.\end{array}$ & $\begin{array}{l}\text { Background Dairy(b) } \\
\qquad(\mathrm{pCi} / \mathrm{L})^{(\mathrm{a})}\end{array}$ & $\begin{array}{r}\text { QC Spike R } \\
\text { Backg } \\
\text { Expected }\end{array}$ & $\begin{array}{l}\text { ery }(\mathrm{pCi} / \mathrm{L})^{(\mathrm{a})} \\
\text { d Dairy } \\
\text { Measured }\end{array}$ \\
\hline January & \pm 0.033 & $0.036 \pm 0.042$ & 3.4 & $2.6 \pm 0.30$ \\
\hline February & $0.059 \pm 0.054$ & $0.094 \pm 0.057$ & 3.4 & $3.7 \pm 0.42$ \\
\hline March & $0.047 \pm 0.039$ & $0.22 \pm 0.09$ & 3.4 & $2.1 \pm 0.4$ \\
\hline April & $0.11 \pm 0.06$ & $0.091 \pm 0.062$ & & \\
\hline May & $0.14 \pm 0.04$ & $0.058 \pm 0.050$ & 3.4 & $2.5 \pm 0.4$ \\
\hline June & $0.15 \pm 0.07$ & $0.11 \pm 0.07$ & & \\
\hline July & $0.020 \pm 0.032$ & $0.067 \pm 0.060$ & 10 & $6.9 \pm 0.70$ \\
\hline August & $0.019 \pm 0.033$ & $0.11 \pm 0.050$ & 3.4 & $4.1 \pm 0.43$ \\
\hline September & $0.020 \pm 0.033$ & $0.034 \pm 0.059$ & 3.6 & $3.8 \pm 0.5$ \\
\hline October & $0.024 \pm 0.042$ & $0.012 \pm 0.043$ & 14 & $18 \pm 2.2$ \\
\hline November & $0.0050 \pm 0.16$ & $0.052 \pm 0.12$ & 3.4 & $4.4 \pm 1.4$ \\
\hline December & $0.095 \pm 0.17$ & $0.13 \pm 0.21$ & 3.3 & $2.6 \pm 0.90$ \\
\hline
\end{tabular}

(a) To obtain $\mathrm{Bq} / \mathrm{L}$, multiply $\mathrm{pCi} / \mathrm{L}$ by 0.037 . Plus/minus $( \pm)$ values are the uncertainty in the analytical results at the $95 \%$ confidence level.

(b) Dairy is about $37 \mathrm{~km}$ (23 miles) WSW of the Fernald site.

(c) Sample invalidated due to error in laboratory processing. 
TABLE 9: Radionuclides in Milk, 1993

\begin{tabular}{|c|c|c|c|c|c|}
\hline Radionuclide & \multicolumn{3}{|c|}{$\begin{array}{l}\text { Local Dairy } \\
(\mathrm{pCi} /)^{(a)}\end{array}$} & \multicolumn{2}{|c|}{$\begin{array}{c}\text { Background Dairy(b) } \\
\left(_{(p C i / L)}(a)\right.\end{array}$} \\
\hline Beryllium-7 & \multicolumn{3}{|c|}{ (c) } & \multicolumn{2}{|c|}{ (c) } \\
\hline Bismuth-214 & \multicolumn{3}{|c|}{ (c) } & \multicolumn{2}{|c|}{ (c) } \\
\hline Cesium-137 & 9.1 & \pm & 5.8 & $8.2 \pm$ & 5.7 \\
\hline Lead-212 & 26 & \pm & 19 & $25 \pm$ & 19 \\
\hline Lead-214 & \multicolumn{3}{|c|}{ (c) } & \multicolumn{2}{|c|}{ (c) } \\
\hline Radium-226 & -1.4 & \pm & 0.31 & $-1.2 \pm$ & 0.32 \\
\hline Radium-228 & \multicolumn{3}{|c|}{ (c) } & \multicolumn{2}{|c|}{ (c) } \\
\hline Protactinium-234 & 1,300 & \pm & 940 & $650 \pm$ & 900 \\
\hline Strontium-90 & \multicolumn{3}{|c|}{ (c) } & \multicolumn{2}{|c|}{ (c) } \\
\hline Technetium-99 & -300 & \pm & 81 & $-180 \pm$ & 6.3 \\
\hline Thallium-208 & 11 & \pm & 8.0 & $8.5 \pm$ & 7.9 \\
\hline Thorium-228 & 1.5 & \pm & 1.1 & $0.047 \pm$ & 0.19 \\
\hline Thorium-230 & 1.1 & \pm & 0.91 & $0.085 \pm$ & 0.08 \\
\hline Thorium-232 & -0.15 & \pm & 0.34 & $0.047 \pm$ & 0.19 \\
\hline Uranium-234 & 0.0013 & \pm & 0.0045 & $0.065 \pm$ & 0.033 \\
\hline Uranium-235 & 0.00065 & \pm & 0.0032 & $-0.0035 \pm$ & 0.0076 \\
\hline Uranium-238 & & (d) & & $0.067 \pm$ & 0.033 \\
\hline
\end{tabular}

(a) To obtain $\mathrm{Bq} / \mathrm{L}$, multiply $\mathrm{pCi} / \mathrm{L}$ by 0.037 . Plus/minus $( \pm$ ) values are the uncertainty in the analytical results at the $95 \%$ confidence ievel. Negative results indicate that the radionuclide activity in the sample was less than the background activity within the measurement laboratory.

(b) Dairy is about $37 \mathrm{~km}$ (23 miles) WSW of the Fernald site.

(c) Laboratory difficulties in analysis resulted in suspect data.

(d) Results not available due to errors in laboratory analysis. 
TABLE 10: Environmental TLD Direct Radiation Measurements, 1993

\begin{tabular}{|c|c|c|c|}
\hline Location Description(a) & $\begin{array}{l}\text { Location } \\
\text { Number }\end{array}$ & $\begin{array}{l}1992 \text { Dose Rate } \\
(\mathrm{mrem} / \mathrm{yr})(\mathrm{b}, \mathrm{c})\end{array}$ & $\begin{array}{l}1993 \text { Dose Rate } \\
\text { (mrem/yr) }^{(b, c)}\end{array}$ \\
\hline \multicolumn{4}{|l|}{ Fenceline } \\
\hline $\operatorname{AMS}{ }_{1}(\mathrm{~d})$ & 1 & $60 \pm 10$ & $64 \pm 2.4$ \\
\hline AMS 2 & 2 & $70 \pm 12$ & $72 \pm 1.5$ \\
\hline AMS 3 & 3 & $68 \pm 11$ & $65 \pm 2.1$ \\
\hline AMS 4 & 4 & $68 \pm 11$ & $67 \pm 1.3$ \\
\hline AMS 5 & 5 & $69 \pm 11$ & $66 \pm 1.1$ \\
\hline AMS 6 & 6 & $65 \pm 11$ & $68 \pm 0.9$ \\
\hline AMS 7 & 7 & $63 \pm 10$ & $64 \pm 1.3$ \\
\hline Site fenceline near $\mathrm{K}-65$ silos & 13 & $68 \pm 11$ & $69 \pm 1.3$ \\
\hline Site fenceline near $K-65$ silos & 14 & $64 \pm 11$ & $65 \pm 1.2$ \\
\hline Site fenceline near $K-65$ silos & 15 & $67 \pm 11$ & $73 \pm 9.1$ \\
\hline Site fenceline near $\mathrm{K}-65$ silos & 16 & $65 \pm 11$ & $68 \pm 1.2$ \\
\hline Site fenceline near $\mathrm{K}-65$ silos & 17 & $66 \pm 11$ & $67 \pm 0.9$ \\
\hline \multicolumn{4}{|l|}{ Onsite } \\
\hline AMS $1 A^{(e)}$ & $1 \mathrm{~A}$ & - & $120 \pm 2.0$ \\
\hline AMS 8 & 8 & $64 \pm 10$ & $67 \pm 2.0$ \\
\hline AMS 9 & 9 & $87 \pm 14$ & $91 \pm 2.7$ \\
\hline K-65 perimeter fence & 22 & $180 \pm 30$ & $250 \pm 13$ \\
\hline $\mathrm{K}-65$ perimeter fence & 23 & $170 \pm 29$ & $260 \pm 10$ \\
\hline K-65 perimeter fence & 24 & $140 \pm 23$ & $160 \pm 2.9$ \\
\hline K-65 perimeter fence & 25 & $150 \pm 24$ & $200 \pm 6.4$ \\
\hline K-65 perimeter fence & 26 & $130 \pm 21$ & $140 \pm 4.3$ \\
\hline OSH Building, Room $218^{(f)}$ & 32 & $47 \pm 8$ & $50 \pm 1.0$ \\
\hline \multicolumn{4}{|l|}{ Offsite } \\
\hline AMS 10 & 10 & $51 \pm 8$ & $52 \pm 1.1$ \\
\hline AMS 11 & 11 & $63 \pm 10$ & $62 \pm 1.0$ \\
\hline AMS 13 & 12 & $56 \pm 9$ & $57 \pm 0.7$ \\
\hline Westwood, $\mathrm{OH}$ & 18 & $67 \pm 11$ & $69 \pm 1.0$ \\
\hline Brookville, IN & 19 & $59 \div 10$ & $61 \pm 0.6$ \\
\hline AMS-15, Miamitown & 20 & $51 \pm 8$ & $54 \pm 3.0$ \\
\hline AMS-16, University of Cincinnati & 21 & $55 \pm 9$ & $56 \pm 0.9$ \\
\hline AMS 12 & 27 & $59 \pm 10$ & $61 \pm 0.8$ \\
\hline Beta Building, St. Rt. $128^{(f)}$ & 30 & $47 \pm 8$ & $53 \pm 1.2$ \\
\hline
\end{tabular}

(a) See Figure 27 on page 79 for locations.

(b) Plus/minus ( \pm ) values are the uncertainty in the analytical results at the $95 \%$ confidence level.

(c) Dose is calculated from the sum of quarterly measurements at each location.

(d) 1993 dose for AMS 1 is based on two quarterly measurements.

(e) 1993 dose for AMS 1A is based on one quarterly measurement. AMS $1 \mathrm{~A}$ was not sampled in 1992.

(f) TLDs 30 and 32 are located inside buildings and are used as control locations. 


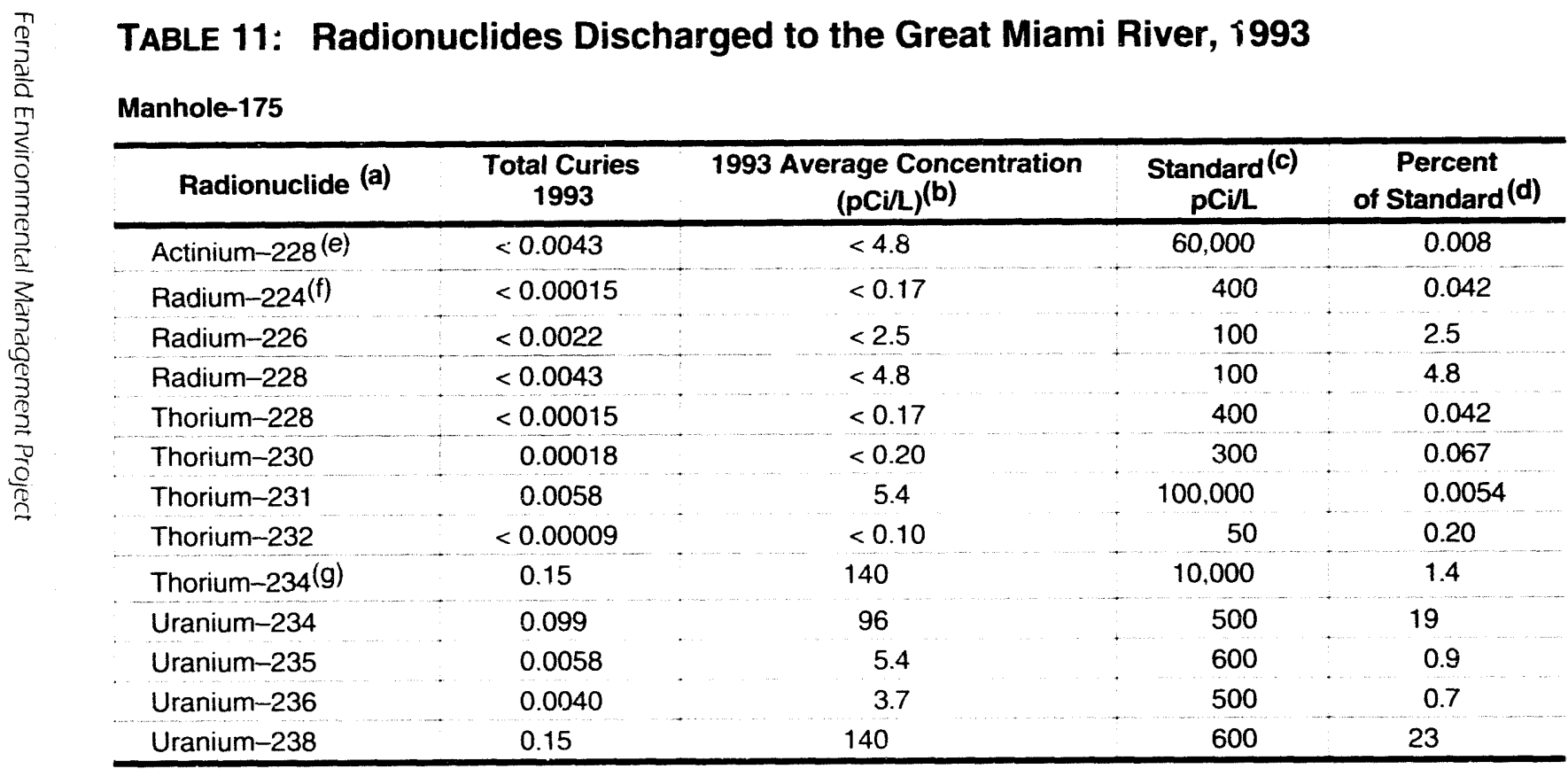

South Plume (SP3)

\begin{tabular}{|c|c|c|c|c|}
\hline Radionuclide (a) & $\begin{array}{c}\text { Total Curies } \\
1993\end{array}$ & $\begin{array}{l}1993 \text { Average Concentration } \\
(\mathrm{pCi} / \mathrm{L})^{(b)}\end{array}$ & $\begin{array}{c}\text { Standard }(c) \\
\mathrm{pCi} / \mathrm{L}\end{array}$ & $\begin{array}{c}\text { Percent } \\
\text { of Standard (d) }\end{array}$ \\
\hline Actinium-228 $(\mathrm{e})$ & $<0.00057$ & $<0.47$ & 60.000 & 0.00078 \\
\hline Radium-224(f) & $<0.00017$ & $<0.14$ & 400 & 0.035 \\
\hline Radium-226 & $<0.0023$ & $<1.9$ & 100 & 1.9 \\
\hline Radium-228 & $<0.00057$ & $<0.47$ & 100 & 0.47 \\
\hline Thorium-228 & $<0.00017$ & $<0.14$ & 400 & 0.035 \\
\hline Thorium-230 & $<0.00057$ & $<0.47$ & 300 & 0.16 \\
\hline Thorium-231 & 0.00032 & 0.10 & 100,000 & 0.00010 \\
\hline Thorium-232 & $<0.0024$ & $<0.10$ & 50 & 0.20 \\
\hline Thorium-234 $(\mathrm{g})$ & 0.0061 & 0.14 & 10,000 & 0.0014 \\
\hline Uranium-234 & 0.0038 & 3.1 & 500 & 0.62 \\
\hline Uranium-235 & 0.00034 & 0.28 & 600 & 0.047 \\
\hline Uranium-236 & $<0.00012$ & $<0.10$ & 500 & 0.020 \\
\hline Uranium-238 & 0.0073 & 6.0 & 600 & 1.0 \\
\hline
\end{tabular}

(a) Radionuclide concentrations in the plant effluent discharged to the Great Miami River through the effluent pipeline are determined from monthly or quanerly composites of daily, 24-hour continuous samples at Discharge 001 (Manhole-175) and $\mathrm{SP3}$

(b) Averages are flow-weighted. To obtain $\mathrm{Bq} / \mathrm{L}$, multiply $\mathrm{pCi} / \mathrm{L}$ by 0.037 .

(c) As stated in DOE Order 5400.5,

"Radiation Protection of the Public and Environment.

(d) Percent of standard relates to the average concentration. Where less than $(<)$ is reported, the maximal possible value is assumed.

(e) Calculated based on radioactive decay equilibrium with radium-228.

(f) Calculated based on radioactive decay equilibrium with thorium-228.

(g) Calculated based on radioactive decay equilibrium with uranium-238. 
TABLE 12: Radionuclides in Surface Water, 1993

\begin{tabular}{|c|c|c|c|c|c|c|c|c|c|}
\hline \multirow{2}{*}{ Parameter } & \multirow{2}{*}{$\begin{array}{l}\text { Sampling } \\
\text { Location(a) }\end{array}$} & \multirow{2}{*}{$\begin{array}{l}\text { Number } \\
\text { of Samples }\end{array}$} & \multicolumn{3}{|c|}{ Concentration $(\mathrm{pCi} / \mathrm{L})^{(\mathrm{b})}$} & \multirow{2}{*}{$\begin{array}{l}\text { Standards } \\
(p C i / L)(c)\end{array}$} & \multicolumn{3}{|c|}{ Percent of Standard } \\
\hline & & & Minimum & Maximum & Average & & Minimum & Maximum & Average \\
\hline \multicolumn{10}{|l|}{ Great Miami River } \\
\hline \multicolumn{10}{|l|}{ Total Uranium } \\
\hline Upstream of Effluent Line & $W_{1}$ & 52 & 0.74 & 1.6 & 1.1 & 550 & 0.13 & 0.29 & 0.20 \\
\hline Downstream of Effluent Line & W3 & 52 & 0.74 & 1.8 & 1.2 & 550 & 0.13 & 0.33 & 0.22 \\
\hline Downstream of Effluent Line & W4 & 52 & 0.81 & 1.6 & 1.2 & 550 & 0.15 & 0.29 & 0.22 \\
\hline \multicolumn{10}{|l|}{ Radium-226(d) } \\
\hline Upstream of Effluent Line & $W_{1}$ & 12 & $<0.60$ & 2.2 & $<2.1$ & 100 & $<0.60$ & 2.2 & $<2.1$ \\
\hline Downstream of Effluent Line & W3 & 12 & $<1.9$ & 5.6 & $<2.4$ & 100 & $<1.9$ & 5.6 & $<2.4$ \\
\hline Downstream of Effluent Line & W4 & 12 & $<1.6$ & 2.5 & $<2.1$ & 100 & $<1.6$ & 2.5 & $<2.1$ \\
\hline \multicolumn{10}{|l|}{ Radium-228(d) } \\
\hline Upstream of Effluent Line & W1 & 12 & $<0.34$ & 4.4 & $<2.0$ & 100 & $<0.34$ & 4.4 & $<2.0$ \\
\hline Downstream of Effluent Line & W3 & 12 & $<0.34$ & 4.4 & $<2.0$ & 100 & $<0.34$ & 4.4 & $<2.0$ \\
\hline Downstream of Effluent Line & W4 & 12 & $<0.34$ & 4.4 & $<1.9$ & 100 & $<0.34$ & 4.4 & $<1.9$ \\
\hline \multicolumn{10}{|l|}{ Strontium-90(d) } \\
\hline Upstream of Effluent Line & W1 & 2 & $<0.39$ & $<0.39$ & $<0.39$ & 1,000 & $<0.039$ & $<0.039$ & $<0.039$ \\
\hline Downstream of Effluent Line & W3 & 2 & $<0.39$ & $<0.39$ & $<0.39$ & 1,000 & $<0.039$ & $<0.039$ & $<0.039$ \\
\hline Downstream of Effluent Line & W4 & 2 & $<0.39$ & $<0.39$ & $<0.39$ & 1,000 & $<0.039$ & $<0.039$ & $<0.039$ \\
\hline \multicolumn{10}{|l|}{ Cesium-137(d) } \\
\hline Upstream of Effluent Line & W1 & 2 & $<4.4$ & $<4.8$ & $<4.6$ & 3,000 & $<0.15$ & $<0.16$ & $<0.15$ \\
\hline Downstream of Effluent Line & W3 & 2 & $<4.7$ & $<4.8$ & $<4.8$ & 3,000 & $<0.16$ & $<0.16$ & $<0.16$ \\
\hline Downstream of Effluent Line & W4 & 2 & $<4.6$ & $<4.8$ & $<4.7$ & 3,000 & $<0.15$ & $<0.16$ & $<0.16$ \\
\hline \multicolumn{10}{|l|}{ Technetium-99(d) } \\
\hline Upstream of Effluent Line & W1 & 2 & $<7.2$ & $<7.3$ & $<7.2$ & 100,000 & $<0.0072$ & $<0.0073$ & $<0.0072$ \\
\hline Downstream of Effluent Line & W3 & 2 & $<7.2$ & $<7.2$ & $<7.2$ & 100,000 & $<0.0072$ & $<0.0072$ & $<0.0072$ \\
\hline Downstream of Effluent Line & W4 & 2 & $<7.3$ & $<7.5$ & $<7.4$ & 100,000 & $<0.0073$ & $<0.0075$ & $<0.0074$ \\
\hline
\end{tabular}



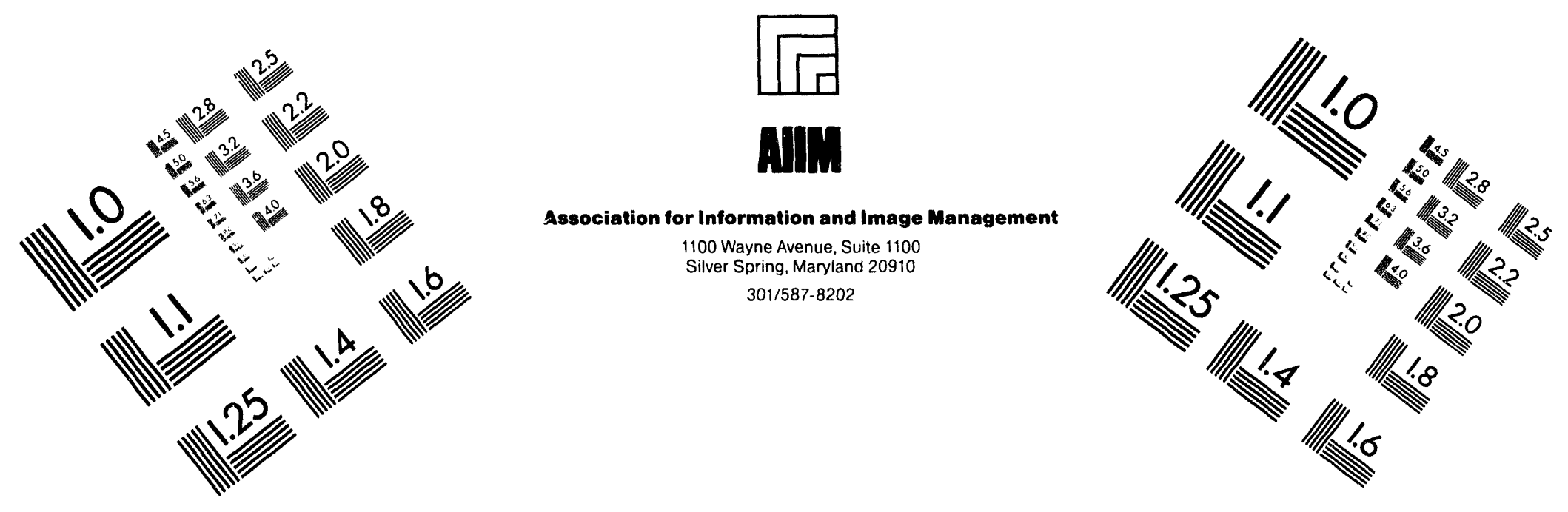

\section{Centimeter}

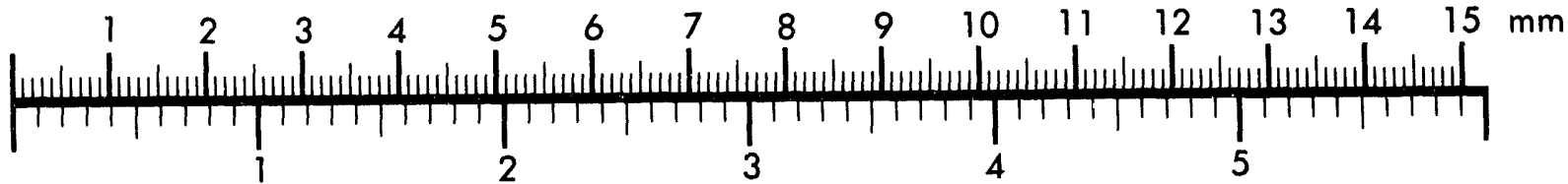
Inches
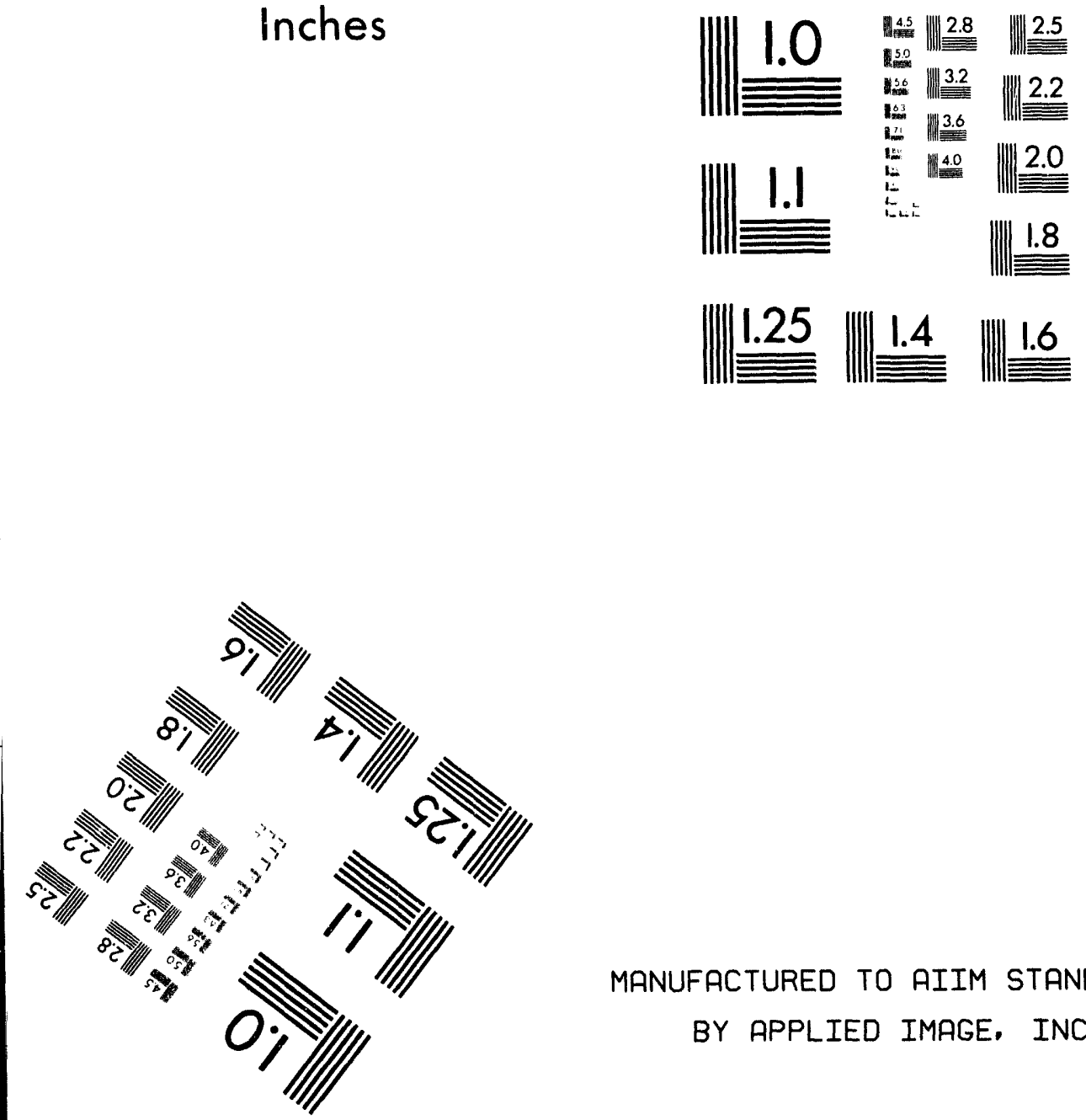

MANUFACTURED TO AIIM STANDARDS BY APPLIED IMAGE, INC.

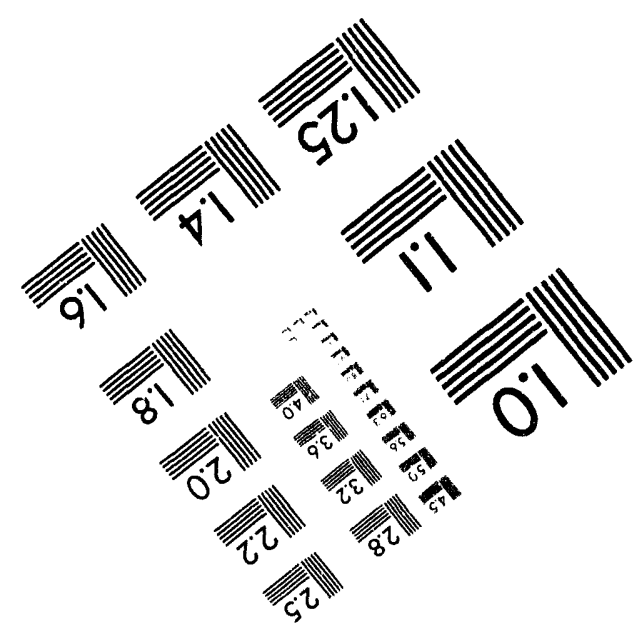




$$
\begin{aligned}
& \omega \\
& \stackrel{o}{\omega} \\
& \omega
\end{aligned}
$$


TABLE 12: Radionuclides in Surface Water, 1993

Page 2 of 2

\begin{tabular}{|c|c|c|c|c|c|c|c|c|c|}
\hline \multirow{2}{*}{ Parameter } & \multirow{2}{*}{$\begin{array}{l}\text { Sampling } \\
\text { Location(a) }\end{array}$} & \multirow{2}{*}{$\begin{array}{c}\text { Number } \\
\text { of Samples }\end{array}$} & \multicolumn{3}{|c|}{ Concentration $(\mathrm{pCi} / \mathrm{L}){ }^{(b)}$} & \multirow{2}{*}{$\begin{array}{l}\text { Standards } \\
(\mathrm{pCi} / \mathrm{L})^{(\mathrm{c})}\end{array}$} & \multicolumn{3}{|c|}{ Percent of Standard } \\
\hline & & & Minimum & Maximum & Average & & Minimum & Maximum & Average \\
\hline \multicolumn{10}{|l|}{ Paddys Run } \\
\hline \multicolumn{10}{|l|}{ Total Uranium } \\
\hline Upstream of the Site & W5 & 47 & 0.34 & 1.4 & 0.67 & 550 & 0.062 & 0.25 & 0.12 \\
\hline Onsite & W9 & 37 & 0.34 & 40 & 2.4 & 550 & 0.062 & 7.3 & 0.44 \\
\hline Onsite & $W-10 \cup S$ & 30 & 0.88 & 430 & 32 & 550 & 0.16 & 78 & 5.8 \\
\hline Onsite & W10 & 30 & 0.81 & 430 & 40 & 550 & 0.15 & 78 & 7.3 \\
\hline Onsite & $W-10 D D$ & 34 & 1.2 & 1,100 & 380 & 550 & 0.22 & 200 & 69 \\
\hline Onsite & $W-10 D S$ & 29 & 1.1 & 470 & 56 & 550 & 0.20 & 85 & 10 \\
\hline Onsite & W11 & 24 & 1.6 & 13 & 4.4 & 550 & 0.29 & 2.4 & 0.80 \\
\hline Downstream of the Site & W7 & 24 & 2.0 & 6.2 & 3.9 & 550 & 0.36 & 1.1 & 0.71 \\
\hline Downstream of the Site & W8 & 39 & 1.2 & 5.7 & 2.8 & 550 & 0.22 & 1.0 & 0.51 \\
\hline \multicolumn{10}{|l|}{ Radium-226(d) } \\
\hline Upstream of the Site & W5 & 6 & $<1.6$ & 2.5 & $<2.1$ & 100 & $<1.6$ & 2.5 & $<2.1$ \\
\hline Downstream of the Site & W7 & 8 & $<1.6$ & 2.2 & $<2.1$ & 100 & $<1.6$ & 2.2 & $<2.1$ \\
\hline Downstream of the Site & W8 & 4 & $<2.2$ & 2.2 & $<2.2$ & 100 & $<2.2$ & 2.2 & $<2.2$ \\
\hline \multicolumn{10}{|l|}{ Radium-228 $(\mathrm{d})$} \\
\hline Upstream of the Site & W5 & 6 & $<0.34$ & 2.2 & $<1.6$ & 100 & $<0.34$ & 2.2 & $<1.6$ \\
\hline Downstream of the Site & W7 & 8 & $<0.34$ & 2.2 & $<1.5$ & 100 & $<0.34$ & 2.2 & $<1.5$ \\
\hline Downstream of the Site & W8 & 4 & $<2.2$ & 2.2 & $<2.2$ & 100 & $<2.2$ & 2.2 & $<2.2$ \\
\hline
\end{tabular}

(a) See Figure 32 on page 88 for sampling locations.

(b) To obtain $\mathrm{Bq} / \mathrm{L}$, multiply $\mathrm{pCi} / \mathrm{L}$ by 0.037

(c) Standards as listed in DOE Order 5400.5, "Radiation Protection of the Public and Environment." The standards are based on drinking 730 liters (about 200 gallons) of water per year. The Fernald site compares data from the Great Miami River and Paddys Run to these standards even though neither is designated as a public water supply by OEPA (OEPA Regulations, Vol. 1, 3475-1-21)

(d) Samples are composited as follows:

- One-month composites of daily samples from W1 and W3,

- One-month composites of weekly samples from W4 and either W7 or W8,

- Two-month composites of weekly samples from W5, and

- Semiannual composites were used for those isotopes where two samples are recorded. 
TABLE 13: Radionuclides in Great Miami River, Paddys Run and Storm Sewer Outfall Ditch Sediments, 1993(a)

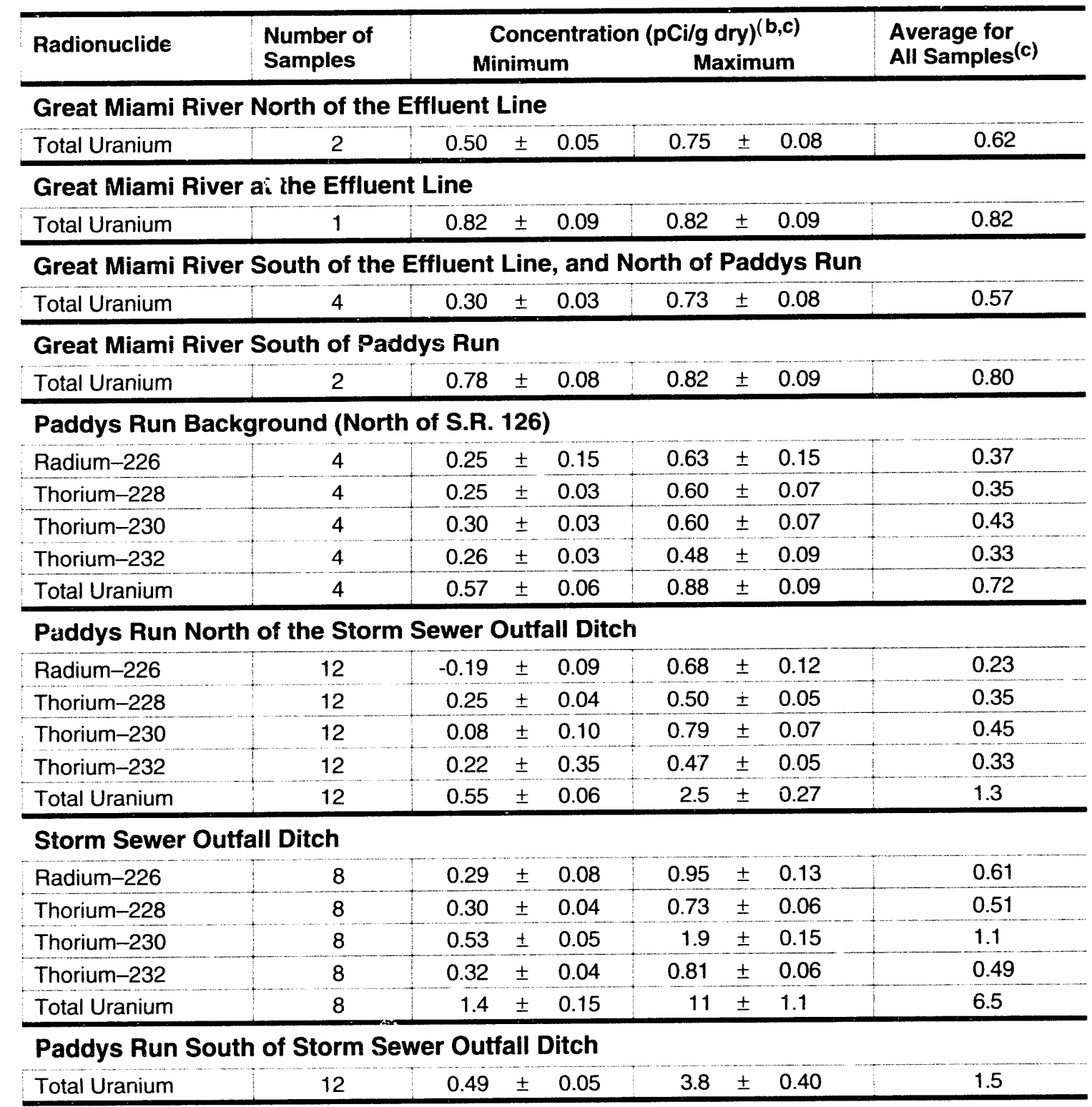

(a) See Figure 34 on page 92 for sampling locations.

(b) Multiply pCi/g by 0.037 to obtain $\mathrm{Bq} / \mathrm{g}$ Negative results indicate that the radionuclide activity in the sample was less than the background activity within the measurement laboratory.

(c) The plus/minus ( \pm ) values are the uncertainty in the analytical results at the $95 \%$ confidence level. 
TABLE 14: Uranium Concentrations in Fish from the Great Miami River, 1993

\begin{tabular}{|c|c|c|c|c|c|}
\hline \multirow{2}{*}{ Sampling Location(a) } & \multirow{2}{*}{ Family (b) } & \multirow{2}{*}{$\begin{array}{l}\text { Number } \\
\text { of Samples }\end{array}$} & \multicolumn{3}{|c|}{ Concentration $\mathrm{pCi} / \mathrm{g}(\mathrm{c})$} \\
\hline & & & Minimum & Maximum & Geometric Mean \\
\hline \multirow{6}{*}{$\begin{array}{l}\text { RM } 38 \\
\text { Upstream of } \\
\text { the Harnitton Dam }\end{array}$} & 1 & 11 & 0.0027 & 0.0094 & 0.0061 \\
\hline & 2 & 4 & 0.0013 & 0.011 & 0.0039 \\
\hline & 3 & 2 & 0.0013 & 0.0020 & 0.0016 \\
\hline & 4 & 6 & 0.0018 & 0.013 & 0.0041 \\
\hline & 5 & 0 & - & - & - \\
\hline & $\begin{array}{l}\text { Location } \\
\text { Summary }\end{array}$ & 23 & 0.0013 & 0.013 & 0.0045 \\
\hline \multirow{6}{*}{$\begin{array}{l}\text { RM } 24 \\
\quad \text { At the Effluent Line }\end{array}$} & 1 & 8 & 0.0033 & 0.012 & 0.0071 \\
\hline & 2 & 3 & 0.0021 & 0.082 & 0.0075 \\
\hline & 3 & 4 & 0.0038 & 0.0081 & 0.0058 \\
\hline & 4 & 1 & 0.0083 & 0.0083 & 0.0083 \\
\hline & 5 & 6 & 0.0025 & 0.029 & 0.0083 \\
\hline & $\begin{array}{l}\text { Location } \\
\text { Summary }\end{array}$ & 22 & 0.0021 & 0.082 & 0.0066 \\
\hline \multirow{6}{*}{$\begin{array}{l}\text { RM } 19 \\
\text { At Confluence } \\
\text { of Paddys Run and } \\
\text { the Great Miami River }\end{array}$} & 1 & 2 & 0.0031 & 0.0052 & 0.0040 \\
\hline & 2 & 4 & 0.0012 & 0.0042 & 0.0026 \\
\hline & 3 & 4 & 0.0013 & 0.0039 & 0.0020 \\
\hline & 4 & 5 & 0.0041 & 0.027 & 0.015 \\
\hline & 5 & 6 & 0.0008 & 0.0034 & 0.0014 \\
\hline & $\begin{array}{l}\text { Location } \\
\text { Summary }\end{array}$ & 21 & 0.0008 & 0.027 & 0.0033 \\
\hline
\end{tabular}

(a) See Figure 35 on page 94 for sampling locations.

(b) Family:

$1=$ Cyprinidae (carp and shiner)

2 = Caiostomidae (carpsucker, redhorse, and buffalo)

3 = Centrarchidae, Percidae, Percichthyidae and Sciaenidae (bass, sunfish, drum, sauger, bluegill, longear, and gar)

4 = Clupeidae (gizzard shad and skipjack herring)

$5=$ Ictaluridae (catfish and bullhead)

(c) All concentrations are reported in dry weight. Multiply by 0.037 to obtain $3 q / g$ (dry weight). 
TABLE 15: NPDES Data, 1993

Page 1 of 3

\begin{tabular}{|c|c|c|c|c|c|c|c|c|}
\hline \multirow{2}{*}{$\begin{array}{l}\text { Sampling Location } \\
\text { and Parameter }\end{array}$} & \multirow{2}{*}{ Units(a) } & \multirow{2}{*}{$\begin{array}{c}\text { Monitoring } \\
\text { Requirsments }\end{array}$} & \multicolumn{3}{|c|}{ Daily Monitoring Results } & \multicolumn{2}{|c|}{ Permit Limits (c) } & \multirow{2}{*}{$\begin{array}{c}\text { Percent } \\
\text { Compliance (d) }\end{array}$} \\
\hline & & & Minimum & Maximum & Average ${ }^{(0)}$ & Daily Maximum & Monthly Average & \\
\hline \multicolumn{9}{|c|}{ Discharge 001 (MH175 to Great Miami) } \\
\hline Flow Rate & MGD & Continuous & 0.052 & 1.7 & 0.64 & NA & NA & NA \\
\hline $\mathrm{pH}$ & S.U. & Continuous & 4.8 & 10 & NA & \multicolumn{2}{|c|}{ Range $=6.5$ to 9.0} & $99.73^{(e)}$ \\
\hline Dissolved Oxygen & $\mathrm{mg} / \mathrm{L}$ & Weekly/Grab & 5.6 & 12 & 8.7 & \multicolumn{2}{|c|}{ Minimum $=5.0$} & 100.0 \\
\hline Suspended Solids & $\mathrm{mg} / \mathrm{L}$ & Wk/24hr Comp & 2.0 & 70 & 9.0 & 45 & 30 & 98.28 \\
\hline Oil \& Grease & $\mathrm{mg} / \mathrm{L}$ & Weekly/Grab & $<5.0$ & 7 & $<5.0$ & 15 & 15 & 100.0 \\
\hline Cyanide $(\mathrm{e})$ & $\mathrm{mg} / \mathrm{L}$ & Weekly/Grab & $<0.005$ & $<0.005$ & $<0.005$ & 0.076 & 0.036 & 100.0 \\
\hline Copper & $\mu g / L$ & Wk/24hr Comp & $<14$ & 20 & $<14$ & 94 & 23 & 100.0 \\
\hline Silver $(e)$ & $\mu g / L$ & Wk/24hr Comp & $<10$ & $\therefore 10$ & $<10$ & 26 & 12 & 100.0 \\
\hline BOD-C & $\mathrm{mg} / \mathrm{L}$ & Wk/24hr Comp & 0.35 & 4.2 & 1.4 & 30 & 20 & 100.0 \\
\hline Lead $(\mathrm{e})$ & $\mu g / L$ & Wk/24hr Comp & $<3.0$ & 5.8 & $<3.3$ & 780 & 60 & 100.0 \\
\hline Suspended Solids & $\mathrm{kg} /$ day & Wk/24hr Comp & 1.6 & 120 & 20 & 150 & 99 & 100.0 \\
\hline Oil \& Grease & $\mathrm{kg} /$ day & Weekly/Grab & $<3.7$ & 28 & $<11$ & 50 & 50 & 100.0 \\
\hline Cyanide $(\mathrm{e})$ & $\mathrm{kg} / \mathrm{day}$ & Weekly/Grab & $<0.0061$ & $<0.028$ & $<0.014$ & 0.25 & 0.12 & 100.0 \\
\hline Copper & $\mathrm{kg} /$ day & Wk/24hr Comp & $<0.010$ & 0.080 & $<0.031$ & 0.31 & 0.077 & 100.0 \\
\hline Silver (e) & $\mathrm{kg} / \mathrm{day}$ & Wk/24hr Comp & $<0.012$ & $<0.056$ & $<0.027$ & 0.086 & 0.040 & 100.0 \\
\hline BOD-C & $\mathrm{kg} /$ day & Wk/24hr Comp & 0.33 & 16 & 3.7 & 99 & 66 & 100.0 \\
\hline \multirow[t]{2}{*}{ Lead $(e)$} & $\mathrm{kg} /$ day & Wk/24hr Comp & $<0.0036$ & 0.019 & $<0.0089$ & 2.6 & 0.20 & 100.0 \\
\hline & & & & & & \multicolumn{2}{|c|}{ Percent Compliance } & 99.79 \\
\hline \multicolumn{9}{|c|}{ Discharge 002 (Spillway to Paddys Run) } \\
\hline Flow Rate & MGD & Estimate & \multirow{9}{*}{\multicolumn{3}{|c|}{$\begin{array}{c}\text { The Stormwater Retention Basin } \\
\text { did not overflow during } 1993 .\end{array}$}} & NA & NA & NA \\
\hline $\mathrm{pH}$ & S.U. & Event/Grab & & & & \multicolumn{2}{|c|}{ Range $=6.5$ to 9.0} & $100.0(e)$ \\
\hline Suspended Solids & $\mathrm{mg} / \mathrm{L}$ & Event/Comp & & & & 100 & NA & 100.0 \\
\hline Chromium (total) & $\mu \mathrm{g} / \mathrm{L}$ & Event/Comp & & & & 3,986 & NA & 100.0 \\
\hline Chromium $(+6)$ & $\mu \mathrm{g} / \mathrm{L}$ & Event/Comp & & & & 19 & NA & 100.0 \\
\hline Oil \& Grease & $\mathrm{mg} / \mathrm{L}$ & Event/Grab & & & & 15 & NA & 100.0 \\
\hline Copper & $\mu \mathrm{g} / \mathrm{L}$ & Event/Comp & & & & 45 & NA & 100.0 \\
\hline Nickel & $\mu \mathrm{g} / \mathrm{L}$ & Event/Comp & & & & 3,137 & NA & 100.0 \\
\hline \multirow[t]{2}{*}{ Silver } & $\mu \mathrm{g} / \mathrm{L}$ & Event/Comp & & & & 11.6 & NA & 100.0 \\
\hline & & & \multicolumn{5}{|c|}{ Percent Compliance } & 100.0 \\
\hline
\end{tabular}


TABLE 15: NPDES Data, 1993

\begin{tabular}{|c|c|c|c|c|c|c|c|c|}
\hline $\begin{array}{l}\text { Sampling Location } \\
\text { and Parameter }\end{array}$ & Units $^{(a)}$ & $\begin{array}{c}\text { Monitoring } \\
\text { Requirements }\end{array}$ & \multicolumn{3}{|c|}{ Daily Monitoring Results } & \multicolumn{2}{|c|}{ Permit Limits (c) } & $\begin{array}{c}\text { Percent } \\
\text { Compliance }(d)\end{array}$ \\
\hline \multicolumn{9}{|c|}{ Discharge 601 (Sewage Treatment Plant) } \\
\hline Flow Rate & MGD & Continuous & 0.018 & 0.34 & 0.17 & NA & NA & NA \\
\hline $\mathrm{pH}(\mathrm{g})$ & S.U. & Continuous & 6.5 & 8.3 & NA & \multicolumn{2}{|c|}{ Range $=6.5$ to 9.0} & 100.0 \\
\hline Suspended Solids & $\mathrm{mg} / \mathrm{L}$ & Wk/24hr Comp & $<2.0$ & 16 & $<3.0$ & 40 & 20 & 100.0 \\
\hline Chromium (total) ${ }^{(f)}$ & $\mu g / L$ & Wk/24hr Comp & $<6.0$ & $<6.0$ & $<6.0$ & 32 & 13 & 100.0 \\
\hline Fecal Coliform (h) & \#Col/100 ml & Wk/24hr Comp & 0.0 & 1,500 & 22 & 2,000 & 1,000 & 100.0 \\
\hline Fluoride $^{(f)}$ & $\mathrm{mg} / \mathrm{L}$ & Wk/24hr Comp & 0.25 & 0.34 & 0.29 & 5.1 & 2.3 & 100.0 \\
\hline Copper $(f)$ & $\mu g / L$ & Wh/24hr Comp & $<14$ & $<14$ & $<14$ & 110 & 53 & 100.0 \\
\hline Nickel $(\mathfrak{f})$ & $\mu g / L$ & Wk/24hr Comp & $<17$ & $<17$ & $<17$ & 49 & 32 & 100.0 \\
\hline BOD-5 & $\mathrm{mg} / \mathrm{L}$ & Wk/24hr Comp & 0.77 & 11 & 2.8 & 40 & 20 & 100.0 \\
\hline Suspended Solids & $\mathrm{kg} /$ day & Wk/24hr Comp & $<0.58$ & 13 & $<2.0$ & 19 & 9.5 & 100.0 \\
\hline Chromium (total) $(\mathrm{f})$ & $\mathrm{kg} /$ day & Wk/24hr Comp & $<0.0022$ & $<0.0053$ & $<0.0041$ & 0.015 & 0.006 & 100.0 \\
\hline Fluoride $^{(f)}$ & $\mathrm{kg} / \mathrm{day}$ & Wk/24hr Comp & 0.096 & 0.29 & 0.20 & 2.4 & 1.1 & 100.0 \\
\hline Copper $(f)$ & $\mathrm{kg} /$ day & Wh/24hr Comp & $<0.0052$ & 0.012 & $<0.0096$ & 0.053 & 0.025 & 100.0 \\
\hline Nickelf $(f)$ & $\mathrm{kg} /$ day & Wk/24hr Comp & $<0.0063$ & $<0.015$ & $<0.012$ & 0.023 & 0.015 & 100.0 \\
\hline \multirow[t]{2}{*}{$\mathrm{BOD}-5$} & $\mathrm{~kg} /$ day & Wk/24hr Comp & 0.39 & 6.8 & 2.0 & 19 & 9.5 & 100.0 \\
\hline & & & & & & \multicolumn{2}{|c|}{ Percent Compliance } & 100.0 \\
\hline \multicolumn{9}{|c|}{ Discharge 602 (General Sump) } \\
\hline Flow Rate & MGD & Continuous & 0.033 & 0.20 & 0.046 & NA & NA & NA \\
\hline $\mathrm{pH}^{(\mathrm{e})}$ & S.U. & Weekly/Grab & 7.0 & 9.1 & NA & \multicolumn{2}{|c|}{ Range $=6.5$ to 9.0} & 94.74 \\
\hline Chromium (total) & $\mu g / L$ & Wk/24hr Comp & $<6.0$ & 22 & $<7.1$ & 54 & 41 & 100.0 \\
\hline Chromium $(+6)^{(e)}$ & $\mu g / L$ & Wk/24hr Comp & $<6.0$ & $<6.0$ & $<6.0$ & 17 & 12 & $i 00.0$ \\
\hline Copper & $\mu g / L$ & Wk/24hr Comp & $<14$ & 24 & $<14$ & 110 & 66 & 100.0 \\
\hline Nickel & $\mu g / L$ & Wk/24hr Comp & $<17$ & 110 & $<20$ & 160 & 91 & 100.0 \\
\hline Chromium (total) & $\mathrm{kg} /$ day & Wk/24hr Comp & $<0.0008$ & 0.0024 & $<0.0011$ & 0.013 & 0.010 & 100.0 \\
\hline Chromium $(+6)^{(e)}$ & $\mathrm{kg} / \mathrm{day}$ & WK/24hr Comp & $<0.0008$ & $<0.0040$ & $<0.0010$ & 0.004 & 0.003 & 100.0 \\
\hline Copper & $\mathrm{kg} /$ day & Wk $24 \mathrm{hr}$ Comp & $<0.0018$ & 0.0064 & $<0.0022$ & 0.027 & 0.016 & 100.0 \\
\hline \multirow[t]{2}{*}{ Nickel } & $\mathrm{kg} /$ day & Wk/24hr Comp & $<0.0021$ & 0.017 & $<0.0032$ & 0.040 & 0.022 & 100.0 \\
\hline & & & & & & \multicolumn{2}{|c|}{ Percent Compliance } & 99.76 \\
\hline \multicolumn{9}{|c|}{ Discharge 604 (LiftStation) (e) } \\
\hline $\begin{array}{l}\text { Flow Rate } \\
\end{array}$ & MGD & Continuous & 0.004 & 0.73 & 0.15 & NA & NA & NA \\
\hline $\mathrm{pH}$ & S.U. & Continuous & 6.7 & 9.2 & NA & \multicolumn{2}{|c|}{ Range 6.5 to 9.0} & $100.0^{(i)}$ \\
\hline Suspended Solids & $\mathrm{mg} / \mathrm{L}$ & WK/24hr Comp & $<2.0$ & 83 & $<12$ & 100 & 30 & 100.0 \\
\hline \multirow[t]{2}{*}{ Oil \& Grease } & $\mathrm{mg} / \mathrm{L}$ & Weekly/Grab & $<5.0$ & 11 & $<5.0$ & 15 & 15 & 100.0 \\
\hline & & & & & & \multicolumn{2}{|c|}{ Percent Compliance } & 100.00 \\
\hline
\end{tabular}


TABLE 15: NPDES Data, 1993

\begin{tabular}{|c|c|c|c|c|c|c|c|c|}
\hline \multirow{2}{*}{$\begin{array}{l}\text { Sampling Location } \\
\text { and Parameter }\end{array}$} & \multirow{2}{*}{ Units $(a)$} & \multirow{2}{*}{$\begin{array}{c}\text { Monitoring } \\
\text { Requirements }\end{array}$} & \multicolumn{3}{|c|}{ Daily Monitoring Results } & \multicolumn{2}{|c|}{ Permit Limits (c) } & \multirow{2}{*}{$\begin{array}{c}\text { Percent } \\
\text { Compliance (d) }\end{array}$} \\
\hline & & & Minimum & Maximum & Average (W) & & & \\
\hline \multicolumn{9}{|c|}{ Discharge 605 (Bioreactor) } \\
\hline Flow Rate & MGD & Continuous & 0.002 & 0.22 & 0.10 & NA & NA & NA \\
\hline $\mathrm{pH}^{(\mathrm{g})}$ & S.U. & Continuous & 6.5 & 8.6 & NA & \multicolumn{2}{|c|}{ Range $=6.5$ to 9.0} & $100.0^{(i)}$ \\
\hline Suspended Solids & $\mathrm{mg} / \mathrm{L}$ & $\mathrm{Wk} / 24 \mathrm{hr}$ Comp & 2.0 & 30 & 11 & 45 & 30 & 100.0 \\
\hline Nitrate-Nitrogen & $\mathrm{mg} / \mathrm{L}$ & Wk/24hr Comp & 0.4 & 30 & 4.7 & 140 & 73 & 100.0 \\
\hline Chromium (total) & $\mu \mathrm{g} / \mathrm{L}$ & Wk/24hr Comp & $<6.0$ & 21 & 9.4 & 27 & 12 & 96.43 \\
\hline Copper & $\mu g / L$ & Wk/24hr Comp & $<14$ & 1 & $<14$ & 90 & 45 & 100.0 \\
\hline Nickel & $\mu \mathrm{g} / \mathrm{L}$ & Wk/24hr Comp & $<17$ & $<17$ & $<17$ & 42 & 29 & 100.0 \\
\hline BOD -5 & $\mathrm{mg} / \mathrm{L}$ & Wk/24hr Comp & 0.30 & 34 & 3.8 & 45 & 30 & 100.0 \\
\hline Suspended Solids & $\mathrm{kg} /$ day & Wk/24hr Comp & 0.18 & 16 & 4.6 & 38 & 26 & 100.0 \\
\hline Nitrate-Nitrogen & $\mathrm{kg} /$ day & Wk/24hr Comp & 0.10 & 16 & 1.4 & 120 & 62 & 100.0 \\
\hline Chromium (total) & $\mathrm{kg} /$ day & Wk/24hr Comp & $<0.0003$ & 0.010 & $<0.0038$ & 0.023 & 0.010 & 100.0 \\
\hline Copper & $\mathrm{kg} /$ day & Wk/24hr Comp & $<0.0006$ & 0.012 & $<0.0058$ & 0.077 & 0.039 & 100.0 \\
\hline Nickel & $\mathrm{kg} /$ day & Wk/24hr Comp & $<0.0008$ & $<0.014$ & $<0.0068$ & 0.036 & 0.025 & 100.0 \\
\hline \multirow[t]{2}{*}{ BOD-5 } & $\mathrm{kg} /$ day & $\mathrm{Wk} / 24 \mathrm{hr}$ Comp & 0.027 & 14 & 1.5 & 38 & 26 & 100.0 \\
\hline & & & & & & \multicolumn{2}{|c|}{ Percent Compliance } & 99.78 \\
\hline \multicolumn{9}{|c|}{ Discharge 606 (Retention Basin) (e) } \\
\hline Flow Rate & MGD & Continuous & 0.037 & 0.75 & 0.38 & NA & NA & NA \\
\hline \multirow[t]{3}{*}{$\mathrm{pH}$} & S.U. & Continuous & 4.5 & 9.6 & NA & \multicolumn{2}{|c|}{ Range $=6.5$ to 9.0} & $97.34(i)$ \\
\hline & & & & & & \multicolumn{2}{|c|}{ Percent Compliance } & 97.34 \\
\hline & & & & & & \multicolumn{2}{|c|}{ Total Compliance } & 99.73 \\
\hline
\end{tabular}

(a) MGD stands for million gallons per day, and S. U. stands for standard units.

(b) Flow-weighted daily averages are shown as le:ss than (<) if more than one quarter of the values were less than the detection limit.

(c) Values have been rounded for consistency of data presentation.

(d) Percent compliance is determined by comparing the noncompliance with the compliance opportunities.

(e) Permit modified to eliminate monitoring requirement effective May 20, 1993.

(f) Permit modified to reduce monitoring requirement to monthly monitoring effective May 20, 1993.

(g) Permit modified to reduce monitoring requirement to daily grab effective May 20, 1993.

(h) Average value has been calculated as a geometric mean.

(i) Individual excursions of less than one hour and the sum of all excursions totalling less than 7.26 hours a month are not noncompliances. 
TABLE 16: Uranium in Private Wells, 1993

\begin{tabular}{|c|c|c|c|c|c|c|c|}
\hline \multirow{2}{*}{$\begin{array}{c}\text { Well } \\
\text { Number (a) }\end{array}$} & \multirow{2}{*}{$\begin{array}{c}\text { Number } \\
\text { of Samples }\end{array}$} & \multicolumn{3}{|c|}{ Concentration $(\mathrm{pCi} / \mathrm{L})^{(\mathrm{b})}$} & \multicolumn{3}{|c|}{ Percent of Standard(c) } \\
\hline & & Minimum & Maximum & Average & Minimum & Maximum & Average \\
\hline 1 & 12 & $<0.1$ & 0.14 & $<0.7$ & $<1.0$ & 1.0 & $<0.52$ \\
\hline 3 & 12 & $<0.1$ & 0.14 & $<0.7$ & $<1.0$ & 1.0 & $<0.50$ \\
\hline 4 & 12 & 0.81 & 2.2 & 1.4 & 6.0 & 16 & 10 \\
\hline 7 & 7 & 0.95 & 1.1 & 1.0 & 7.0 & 8.0 & 7.5 \\
\hline 8 & 12 & 0.54 & 0.61 & 0.59 & 4.0 & 4.5 & 4.3 \\
\hline 9 & 12 & 0.74 & 1.4 & 1.0 & 5.5 & 11 & 7.7 \\
\hline 10 & 12 & 0.27 & 0.47 & 0.37 & 2.0 & 3.5 & 2.8 \\
\hline 11 & 12 & 0.81 & 1.5 & 1.1 & 6.0 & 11 & 8.2 \\
\hline $12^{(d)}$ & 12 & 28 & 110 & 59 & 210 & 800 & 440 \\
\hline $13^{(d)}$ & 26 & 30 & 53 & 44 & 230 & 390 & 330 \\
\hline 14 & 24 & 1.0 & 1.4 & 1.2 & 7.5 & 10 & 9.0 \\
\hline $15^{(d)}$ & 12 & 150 & 210 & 190 & 1,100 & 1,600 & 1,400 \\
\hline 16 & 12 & 0.34 & 0.61 & 0.50 & 2.5 & 4.5 & 3.7 \\
\hline 18 & 12 & 0.20 & 0.34 & 0.27 & 1.5 & 2.5 & 2.0 \\
\hline 19 & 11 & $<0.1$ & 0.10 & $<0.05$ & $<1.0$ & 0.74 & $<0.37$ \\
\hline 21 & 12 & 0.14 & 0.27 & 0.21 & 1.0 & 2.0 & 1.6 \\
\hline 22 & 12 & 0.61 & 1.2 & 0.78 & 4.5 & 8.0 & 5.8 \\
\hline 23 & 12 & 0.27 & 0.95 & 0.59 & 2.0 & 7.0 & 4.4 \\
\hline 24 & 12 & 0.20 & 0.41 & 0.34 & 1.5 & 3.0 & 2.6 \\
\hline 25 & 4 & 0.20 & 0.27 & 0.25 & 1.5 & 2.0 & 1.9 \\
\hline 26 & 12 & $<0.1$ & 0.14 & $<0.08$ & $<1.0$ & 1.0 & $<0.59$ \\
\hline 28 & 4 & 0.54 & 0.68 & 0.59 & 4.0 & 5.0 & 4.4 \\
\hline 29 & 12 & 1.2 & 1.6 & 1.3 & 9.0 & 12 & 9.6 \\
\hline 30 & 4 & 0.27 & 0.34 & 0.32 & 2.0 & 2.5 & 2.4 \\
\hline 32 & 12 & $<0.1$ & 0.20 & $<0.07$ & $<1.0$ & 1.5 & $<0.51$ \\
\hline 33 & 12 & 0.20 & 0.41 & 0.34 & 1.5 & 3.0 & 2.5 \\
\hline 34 & 7 & 2.7 & 5.1 & 4.0 & 20 & 38 & 29 \\
\hline 35 & 12 & 1.2 & 1.6 & 1.3 & 8.0 & 12 & 9.6 \\
\hline 36 & 12 & 0.68 & 0.95 & 0.75 & 5.0 & 7.0 & 5.6 \\
\hline 37 & 1 & - & - & 1.1 & - & - & 8.1 \\
\hline $38^{(e)}$ & 4 & 0.07 & 0.27 & 0.19 & 0.5 & 2.0 & 1.4 \\
\hline $39^{(d)}$ & 12 & 3.2 & 6.7 & 4.4 & 24 & 50 & 33 \\
\hline $40^{(d)}$ & 12 & 2.0 & 2.9 & 2.4 & 15 & 22 & 18 \\
\hline 41 & 12 & 0.34 & 0.41 & 0.35 & 2.5 & 3.0 & 2.6 \\
\hline 55 & 4 & 0.14 & 0.34 & 0.25 & 1.0 & 2.5 & 1.9 \\
\hline 56 & 5 & 0.27 & 1.8 & 0.71 & 2.0 & 13 & 5.3 \\
\hline
\end{tabular}

(a) See Figure 36 on pag 3100 for well locations. Wells are numbered in order of first time sampled.

(b) To obtain $\mathrm{Bq} / \mathrm{L}$, multiply $\mathrm{pCi} / \mathrm{L}$ by 0.037 .

(c) Proposed USEPA standard of 13.5 $\mathrm{pCi} / \mathrm{L}(20 \mathrm{ppb})$.

(d) These wells are used for monitoring purposes only.

(e) Sample collected from a cistern 
TABLE 17: Comprehensive Groundwater Samples with Uranium Concentrations above USEPA Proposed Standard, 1993 (a)

\begin{tabular}{|c|c|c|c|c|}
\hline Well(b) & Location & Sample Date & $\begin{array}{l}\text { Concentration } \\
(\mathrm{pCi} / \mathrm{L})(\mathrm{c})\end{array}$ & $\begin{array}{l}\text { Concentration } \\
\text { (ppb) }\end{array}$ \\
\hline 1011 & West of Pit \# 5 & July 16 & 30 & 45 \\
\hline 1011 & West of Pit \# 5 & July 16 & 28 & 41 \\
\hline 1025 & Pit \# 5 & July 7 & 19 & 28 \\
\hline 1027 & Pit \#6 & April 16 & 300 & 440 \\
\hline 1027 & Pit \# 6 & April 16 & 280 & 420 \\
\hline 1032 & K-65 Silo Area & July 7 & 140 & 210 \\
\hline 1033 & K-65 Silo Area & July 12 & 19 & 28 \\
\hline 1033 & K-65 Silo Area & July 12 & 19 & 27 \\
\hline 1037 & Production Area & July 7 & 1,000 & 1,500 \\
\hline 1037 & Production Area & July 7 & 760 & 1,100 \\
\hline 1042 & $\mathrm{~W}$ of Production Area & April 22 & 27 & 40 \\
\hline 1042 & W of Production Area & April 22 & 21 & 30 \\
\hline 1046 & SW of S. Water Ret. & May 11 & 15 & 22 \\
\hline 1048 & SW of S. Water Ret. & April 28 & 21 & 31 \\
\hline 1054 & Production Area & June 23 & 48 & 71 \\
\hline 1054 & Production Area & June 23 & 33 & 49 \\
\hline 1054 & Production Area & June 25 & 38,000 & 56,000 \\
\hline 1055 & Production Area & May 15 & 28 & 42 \\
\hline 1073 & Pit \# 1 & July 15 & 1,700 & 2,600 \\
\hline 1073 & Pit \# 1 & July 15 & 1,600 & 2,400 \\
\hline 1081 & Production Area & April 13 & 15 & 23 \\
\hline 1081 & Production Area & April 13 & 15 & 22 \\
\hline 1082 & Pit \# 6 & April 13 & 510 & 750 \\
\hline 1082 & Pit \# 6 & April 13 & 460 & 690 \\
\hline 1083 & Pit \# 6 & April 16 & 98 & 140 \\
\hline 1083 & Pit \# 6 & April 16 & 96 & 140 \\
\hline 1084 & Pit \# 4 & July 24 & 83 & 79 \\
\hline 1084 & Pit \# 4 & July 24 & 47 & 69 \\
\hline 1085 & Production Area & April 21 & 3,700 & 5,500 \\
\hline 1085 & Production Area & April 21 & 3,500 & 5,200 \\
\hline 1110 & Production Area & June 10 & 35 & 51 \\
\hline
\end{tabular}

\begin{tabular}{|c|c|c|c|c|}
\hline Well(b) & Location & Sample Date & $\begin{array}{c}\text { Concentration } \\
(\mathrm{pCi} / \mathrm{L})(\mathrm{c})\end{array}$ & $\begin{array}{l}\text { Concentration } \\
\text { (ppb) }\end{array}$ \\
\hline$\$ 110$ & Production Area & June 10 & 28 & 42 \\
\hline 1111 & Production Area & June 10 & 17 & 25 \\
\hline 1112 & Production Area & June 11 & 580 & 860 \\
\hline 1112 & Production Area & June 11 & 330 & 480 \\
\hline 1113 & Production Area & June 10 & 1,300 & 1900 \\
\hline 1131 & Production Area & May 27 & 430 & 640 \\
\hline 1145 & Production Area & June 17 & 17,000 & 25,000 \\
\hline 1145 & Production Area & June 17 & 17,000 & 25,000 \\
\hline 1149 & Production Area & February 3 & 63,000 & 94,000 \\
\hline 1157 & Production Area & June 10 & 24 & 35 \\
\hline 1157 & Production Area & June 10 & 20 & 30 \\
\hline 1161 & Production Area & February 23 & 68,000 & 100,000 \\
\hline 1177 & Production Area & May 21 & 52 & 77 \\
\hline 1177 & Production Area & May 21 & 32 & 47 \\
\hline 1179 & Production Area & June 16 & 87 & 130 \\
\hline 1179 & Production Area & June 16 & 60 & 89 \\
\hline 1182 & Production Area & June 16 & 650 & 970 \\
\hline 1186 & Production Area & June 25 & 40,000 & 59,000 \\
\hline 1189 & Production Area & June 28 & 12,000 & 17,000 \\
\hline 1189 & Production Area & June 28 & 9,900 & 15,000 \\
\hline 1195 & Production Area & June 28 & 5,800 & 8,600 \\
\hline 1195 & Production Area & June 28 & 6,000 & 8,800 \\
\hline 1196 & Production Area & October 27 & 7,700 & 11,000 \\
\hline 1201 & Production Area & June 29 & 240 & 350 \\
\hline 1201 & Production Area & June 29 & 150 & 220 \\
\hline 1210 & Production Area & July 14 & 36 & 54 \\
\hline 1210 & Production Area & July 14 & 35 & 52 \\
\hline 1213 & Production Area & March 9 & 7,600 & 11,000 \\
\hline 1214 & Production Area & June 29 & 52,000 & 78,000 \\
\hline 1214 & Production Area & June 29 & 61,000 & 75,000 \\
\hline 1216 & Production Area & June 9 & 340 & 510 \\
\hline
\end{tabular}


TABLE 17: Comprehensive Groundwater Samples with Uranium

Concentrations above USEPA Proposed Standard, 1993 (a)

\begin{tabular}{|c|c|c|c|c|}
\hline Well(b) & Location & Sample Date & $\begin{array}{c}\text { Concentration } \\
(\mathrm{pCi} / \mathrm{L})^{(\mathrm{c})}\end{array}$ & $\begin{array}{c}\text { Concentration } \\
\text { (ppb) }\end{array}$ \\
\hline 1216 & Production Area & June 9 & 280 & 410 \\
\hline 1218 & Production Area & May $1 \%$ & 62 & 92 \\
\hline 1218 & Production Area & May 17 & 55 & 82 \\
\hline 1230 & Production Area & May 17 & 1,400 & 2,100 \\
\hline 1230 & Production Area & May 17 & 700 & 1,000 \\
\hline 1234 & Production Area & May 17 & 970 & 1,400 \\
\hline 1234 & Production Area & May 17 & 930 & 1,400 \\
\hline 1236 & Production Area & May 17 & 3,100 & 4,600 \\
\hline 1236 & Production Area & May 17 & 390 & 580 \\
\hline 1239 & Production Area & May 13 & 22 & 32 \\
\hline 1240 & Production Area & May 15 & 770 & 1,100 \\
\hline 1240 & Production Area & May 15 & 740 & 1,100 \\
\hline 1241 & Production Area & May 15 & 580 & 860 \\
\hline 1241 & Production Area & May 15 & 310 & 460 \\
\hline 1242 & Production Area & May 15 & 860 & 1,300 \\
\hline 1242 & Production Area & May 15 & 92 & 140 \\
\hline 1246 & Production Area & July 22 & 78 & 120 \\
\hline 1246 & Production Area & July 22 & 70 & 100 \\
\hline 1255 & Production Area & May 13 & 520 & 760 \\
\hline 1255 & Production Area & May 13 & 310 & 460 \\
\hline 1267 & Production Area & May 16 & 44 & 65 \\
\hline 1267 & Production Area & May 16 & 38 & 56 \\
\hline 1269 & Production Area & May 11 & 17 & 25 \\
\hline 1269 & Production Area & May 11 & 14 & 21 \\
\hline 1279 & Production Area & May 25 & 69 & 100 \\
\hline 1279 & Production Area & June 2 & 62 & 92 \\
\hline 1279 & Production Area & June 26 & 40 & 60 \\
\hline 1279 & Production Area & June 29 & 35 & 52 \\
\hline 1279 & Production Area & June 29 & 32 & 48 \\
\hline 1281 & Production Area & June 30 & 550 & 810 \\
\hline 1281 & Production Area & June 30 & 530 & 790 \\
\hline
\end{tabular}

\begin{tabular}{|c|c|c|c|c|}
\hline Well(b) & Location & Sample Date & $\begin{array}{l}\text { Concentration } \\
(\mathrm{pCi} / \mathrm{L})^{(\mathrm{c})}\end{array}$ & $\begin{array}{c}\text { Concentration } \\
\text { (ppb) }\end{array}$ \\
\hline 1283 & Production Area & May 25 & 59 & 88 \\
\hline 1283 & Production Area & May 25 & 41 & 61 \\
\hline 1287 & Production Area & May 25 & 140 & 200 \\
\hline 1287 & Production Area & May 25 & 140 & 200 \\
\hline 1287 & Production Area & May $<\Xi$ & 140 & 200 \\
\hline 1291 & Production Area & July 1 & 640 & 940 \\
\hline 1324 & Production Area & July 10 & 92,000 & 140,000 \\
\hline 1324 & Production Area & July 10 & 87.000 & 130,000 \\
\hline 1336 & Production Area & May 27 & 110 & 170 \\
\hline 1336 & Production Area & May 27 & 110 & 160 \\
\hline 1338 & Production Area & July 8 & 780 & 1.100 \\
\hline 1339 & Production Area & May 26 & 450 & 670 \\
\hline 1339 & Production Area & May 26 & 430 & 640 \\
\hline 1339 & Production Area & July 7 & 410 & 600 \\
\hline 1352 & Production Area & May 28 & 40 & 59 \\
\hline 1352 & Production Area & May 28 & 39 & 58 \\
\hline 1357 & Production Area & May 28 & 24 & 36 \\
\hline 1359 & Production Area & May 26 & 340 & 500 \\
\hline 1359 & Production Area & May 26 & 280 & 420 \\
\hline 1359 & Production Area & May 26 & 34 & 50 \\
\hline 1361 & Production Area & May 27 & 32 & 40 \\
\hline 1403 & Production Area & May 16 & 32 & 48 \\
\hline 1403 & Production Area & May 16 & 100 & 160 \\
\hline 1441 & Waste Treatment Plant & May 25 & 96 & 140 \\
\hline 1441 & Waste Treatment Plant & May 25 & 78 & 120 \\
\hline 1442 & Waste Treatment Plant & July 8 & 200 & 290 \\
\hline 1447 & Waste Treatment Plant & May 26 & 180 & 270 \\
\hline 1447 & Waste Treatment Plant & May 26 & 290 & 430 \\
\hline 1509 & Production Area & June 2 & 240 & 360 \\
\hline 1509 & Production Area & June 2 & 110 & 170 \\
\hline 1511 & Production Area & June 2 & 93 & 140 \\
\hline
\end{tabular}


TABLE 17: Comprehensive Groundwater Samples with Uranium Concentrations above USEPA Proposed Standard, 1993 (a)

\begin{tabular}{|c|c|c|c|c|}
\hline Well(b) & Location & Sample Date & $\begin{array}{l}\text { Concentration } \\
(\mathrm{pCi} / \mathrm{L})(\mathrm{c})\end{array}$ & $\begin{array}{c}\text { Concentration } \\
\text { (ppb) }\end{array}$ \\
\hline 1511 & Production Area & June 2 & 93 & 140 \\
\hline 1523 & Production Area & April 16 & 20 & 30 \\
\hline 1523 & Production Area & April 16 & 18 & 27 \\
\hline 1643 & Pit \# 4 & April 13 & 63 & 93 \\
\hline 1643 & Pit \# 4 & April 13 & 55 & 82 \\
\hline 1644 & Pit \# 4 & April 17 & 49 & 73 \\
\hline 1644 & Pit \# 4 & April 17 & 49 & 73 \\
\hline 1645 & Pit \# 4 & April 17 & 24 & 36 \\
\hline 1645 & Pit \# 4 & April 17 & 21 & 32 \\
\hline 1646 & Pit \# 4 & April 17 & 290 & 420 \\
\hline 1646 & Pit \# 4 & April 17 & 280 & 410 \\
\hline 1676 & Production Area & May 12 & 19 & 29 \\
\hline 1676 & Production Area & May 12 & 18 & 26 \\
\hline 1840 & Production Area & May 4 & 160 & 230 \\
\hline 1842 & Production Area & Sept. 24 & 130 & 190 \\
\hline 1842 & Production Area & March 9 & 66 & 97 \\
\hline 1869 & Production Area & May 4 & 20 & 29 \\
\hline 1891 & K-65 Silo Area & April 23 & 210 & 320 \\
\hline 1892 & K-65 Silo Area & April 23 & 840 & 1,200 \\
\hline 1941 & Southwest of SWRB & April 30 & 370 & 550 \\
\hline 1941 & Southwest of SWRB & May 28 & 260 & 390 \\
\hline 1942 & Southwest of SWRB & May 28 & 390 & 570 \\
\hline 1942 & Southwest of SWRB & May 1 & 230 & 340 \\
\hline 1952 & NW of Production Area & May 15 & 38 & 60 \\
\hline 1954 & Southwest of SWRB & June 22 & 44 & 64 \\
\hline 1954 & Southwest of SWRB & June 22 & 26 & 39 \\
\hline 2009 & SW of K-65 Silo Area & June 7 & 18 & 27 \\
\hline 2009 & SW of K-65 Silo Area & June 7 & 18 & 27 \\
\hline 2015 & South Plume, Onsite & May 24 & 130 & 200 \\
\hline 2015 & South Plume, Onsite & May 24 & 130 & 200 \\
\hline 2028 & Pit \# 3 & July 28 & 17 & 25 \\
\hline
\end{tabular}

\begin{tabular}{|c|c|c|c|c|}
\hline Well(b) & Location & Sample Date & $\begin{array}{c}\text { Concentration } \\
(\mathrm{pCi} / \mathrm{L})(\mathrm{c})\end{array}$ & $\begin{array}{c}\text { Concentration } \\
\text { (ppb) }\end{array}$ \\
\hline 2032 & K-65 Silo Area & June 7 & 14 & 21 \\
\hline 2032 & K-65 Silo Area & May 14 & 14 & 20 \\
\hline 2045 & South Plume. Onsite & August 3 & 350 & 520 \\
\hline 2045 & South Plume, Onsite & April 28 & 260 & 380 \\
\hline 2045 & South Plume, Onsite & April 28 & 250 & 360 \\
\hline 2046 & Southwest of SWRB & May 11 & 310 & 460 \\
\hline 2046 & Southwest of SWRB & May 11 & 290 & 420 \\
\hline 2049 & South Plume, Onsite & May 10 & 75 & 110 \\
\hline 2049 & South Plume, Onsite & May 10 & 61 & 90 \\
\hline 2049 & South Plume, Onsite & August 11 & 42 & 62 \\
\hline 2084 & Southwest of SWRB & April 8 & 18 & 27 \\
\hline 2084 & Southwest of SWRB & April 8 & 16 & 24 \\
\hline 2095 & South Plume, Ofisite & May 11 & 63 & 93 \\
\hline 2095 & South Plume, Offsite & May 11 & 54 & 82 \\
\hline 2106 & South Plume, Onsite & July 26 & 47 & 70 \\
\hline 2106 & South Plume, Onsite & August 16 & 39 & 57 \\
\hline 2106 & South Plume, Onsite & April 17 & 46 & 68 \\
\hline 2106 & South Plume, Onsite & April 17 & 42 & 62 \\
\hline 2108 & SW of K-65 Silo Area & June 7 & 17 & 25 \\
\hline 2108 & SW of K-65 Silo Area & June 7 & 15 & 22 \\
\hline 2125 & South Plume, Offsite & May 20 & 29 & 43 \\
\hline 2125 & South Plume, Offsite & May 20 & 28 & 41 \\
\hline 2166 & South Plume, Onsite & January 25 & 72 & 110 \\
\hline 2385 & South of SWRB & April 28 & 67 & 99 \\
\hline 2385 & South of SWRB & April 28 & 56 & 82 \\
\hline 2387 & South Plume, Onsite & April 23 & 240 & 350 \\
\hline 2387 & South Plume, Onsite & April 23 & 220 & 330 \\
\hline 2387 & South Plume, Onsite & August 5 & 190 & 290 \\
\hline 2390 & South Plume, Onsite & June 2 & 82 & 120 \\
\hline 2390 & South Plume, Onsite & June 2 & 82 & 120 \\
\hline 2397 & South of SWRB & August 2 & 340 & 500 \\
\hline
\end{tabular}


TABLE 17: Comprehensive Groundwater Samples with Uranium

Concentrations above USEPA Proposed Standard, 1993 (a)

\begin{tabular}{|c|c|c|c|c|}
\hline Well(b) & Location & Sample Date & $\begin{array}{l}\text { Concentration } \\
(\mathrm{pCi} / \mathrm{L})(\mathrm{c})\end{array}$ & $\begin{array}{l}\text { Concentration } \\
\text { (ppb) }\end{array}$ \\
\hline 2397 & South of SWRB & May 12 & 210 & 320 \\
\hline 2397 & South of SWRB & May 12 & 200 & 300 \\
\hline 2545 & South Plume, Offsite & May 25 & 45 & 66 \\
\hline 2545 & South Plume, Offsite & May 25 & 33 & 49 \\
\hline 2550 & South Plume, Offsite & May 11 & 64 & 94 \\
\hline 2550 & South Plume, Offsite & May 11 & 51 & 76 \\
\hline 2551 & South Plume, Offsite & May 17 & 40 & 58 \\
\hline 2551 & South Plume, Offsite & May 17 & 37 & 55 \\
\hline 2624 & South Plume, Offsite & May 25 & 41 & 61 \\
\hline 2648 & Pit \# 4 & April 16 & 16 & 24 \\
\hline 2648 & Pit \# 4 & April 16 & 15 & 22 \\
\hline 2821 & Pit \#2 & April 7 & 24 & 35 \\
\hline 2821 & Pit \#2 & April 7 & 22 & 33 \\
\hline 2822 & Pit \# 1 & April 26 & 45 & 66 \\
\hline 2822 & Pit \# 1 & April 26 & 44 & 65 \\
\hline 2945 & Southwest of SWRB & April 28 & 1.400 & 2.100 \\
\hline 2945 & Southwest of SWRB & May 26 & 1,200 & 1,800 \\
\hline 2954 & Southwest of SWRB & June 21 & 790 & 1,200 \\
\hline 2954 & Southwest of SWRB & June 21 & 760 & 1,100 \\
\hline 3001 & West of Pit \# 2 & April 5 & 19 & 28 \\
\hline 3001 & West of Pit \#2 & April 5 & 15 & 22 \\
\hline 3014 & South Plume, Onsite & May 6 & 14 & 20 \\
\hline 3037 & Production Area & April 22 & 20 & 29 \\
\hline 3069 & South Plume, Onsite & April 6 & 15 & 22 \\
\hline 3069 & South Plume, Onsite & Apirl 6 & 14 & 21 \\
\hline 3084 & Pit \# 5 & April 8 & 55 & 82 \\
\hline 3084 & Pit \# 5 & April 8 & 53 & 78 \\
\hline
\end{tabular}

\begin{tabular}{|c|c|c|c|c|}
\hline Well(b) & Location & Sample Date & $\begin{array}{c}\text { Concentration } \\
(p \mathrm{Ci} / \mathrm{L})^{(c)}\end{array}$ & $\begin{array}{c}\text { Concentration } \\
\text { (ppb) }\end{array}$ \\
\hline 3084 & Pit \#5 & August 17 & 22 & 33 \\
\hline 3084 & Pit \# 5 & August 17 & 20 & 30 \\
\hline 3108 & South of K-65 Silo Area & June 7 & 21 & 32 \\
\hline 3108 & South of K-65 Silo Area & June 7 & 21 & 32 \\
\hline 3125 & South Plume, Offsite & May 20 & 32 & 48 \\
\hline 3125 & South Plume, Offsite & May 20 & 31 & 45 \\
\hline 3390 & South Plume, Onsite & June 3 & 70 & 100 \\
\hline 3689 & South Plume, Offsite & May 14 & 35 & 52 \\
\hline 3689 & South Plume, Offsite & May 14 & 23 & 34 \\
\hline 3880 & South Plume, Offsite & April 28 & 35 & 52 \\
\hline 4013 & Production Area & April 20 & 20 & 30 \\
\hline 11032 & South of SWRB & June 30 & 15 & 23 \\
\hline 11069 & SW of Production Area & July 24 & 18 & 27 \\
\hline 11069 & SW of Production Area & July 25 & 14 & 20 \\
\hline 11107 & Production Area & August 3 & 310 & 460 \\
\hline 11107 & Production Area & August 5 & 83 & 120 \\
\hline 11107 & Production Area & July 30 & 21 & 31 \\
\hline 11107 & Production Area & July 30 & 54 & 80 \\
\hline 11107 & Production Area & August 3 & 36 & 54 \\
\hline 11107 & Production Area & August 3 & 36 & 54 \\
\hline 11107 & Production Area & July 5 & 43 & 65 \\
\hline 11230 & Production Area & Sept. 8 & 630 & 940 \\
\hline 11230 & Production Area & Sept. 9 & 280 & 420 \\
\hline 11229 & Fire Training Facility & Sept. 16 & 26 & 38 \\
\hline 11229 & Fire Training Facility & Sept. 16 & 25 & 37 \\
\hline 21033 & South Plume, onsite & June 17 & 29 & 43 \\
\hline 21033 & South Plume, onsite & June 17 & 28 & 41 \\
\hline
\end{tabular}

(a) Proposed USEPA standard of $13.5 \mathrm{pCi} / \mathrm{L}(20 \mathrm{ppb})$.

(b) See figures 41 through 44 on pages 109 through 112 for well locations.

(c) To obtain $\mathrm{Bq} / \mathrm{L}$, multiply $\mathrm{pCi} / \mathrm{L}$ by 0.037 . 
TABLE 18: Metals in Private Welis, 1993

Metals Listed in Primary Drinking Water Regulations

\begin{tabular}{|c|c|c|c|c|c|c|c|}
\hline \multirow{2}{*}{$\begin{array}{c}\text { Well } \\
\text { Number (a) }\end{array}$} & \multirow[b]{2}{*}{ Arsenic } & \multirow[b]{2}{*}{ Barium } & \multicolumn{2}{|c|}{ Concentration (mg/L) } & \multirow[b]{2}{*}{ Copper } & \multirow[b]{2}{*}{ Lead } & \multirow{2}{*}{ Selenium } \\
\hline & & & Cadmium & Chromium & & & \\
\hline 1 & 0.018 & 0.42 & $<0.0050$ & $<0.010$ & $<0.025$ & 0.0048 & $<0.0050$ \\
\hline 3 & 0.018 & 0.51 & $<0.0050$ & $<C .010$ & $<0.025$ & $<0.0030$ & $<0.0050$ \\
\hline 4 & $<0.010$ & $<0.20$ & $<0.0050$ & $<0.010$ & $<0.025$ & 0.0068 & $<0.0050$ \\
\hline 7 & $<0.010$ & $<0.20$ & $<0.0050$ & $<0.010$ & $<0.025$ & $<0.0030$ & $<0.0050$ \\
\hline 8 & $<0.010$ & $<0.20$ & $<0.0050$ & $<0.010$ & $<0.025$ & $<0.0030$ & $<0.0050$ \\
\hline 9 & $<0.010$ & $<0.20$ & $<0.0050$ & $<0.010$ & $<0.025$ & $<0.0030$ & $<0.0050$ \\
\hline 10 & $<0.010$ & $<0.20$ & $<0.0050$ & $<0.010$ & $<0.025$ & $<0.0030$ & $<0.0050$ \\
\hline 11. & $<0.010$ & $<0.20$ & $<0.0050$ & $<0.010$ & 0.030 & 0.020 & $<0.0050$ \\
\hline 12 & $<0.010$ & $<0.20$ & $<0.0050$ & $<0.010$ & 0.055 & 0.043 & $<0.0050$ \\
\hline 13 & $<0.010$ & $<0.20$ & $<0.0050$ & $<0.010$ & $<0.025$ & $<0.0030$ & $<0.0050$ \\
\hline 14 & $<0.010$ & $<0.20$ & $<0.0050$ & $<0.010$ & $<0.025$ & 0.0077 & $<0.0050$ \\
\hline 15 & $<0.010$ & $<0.20$ & $<0.0050$ & $<0.010$ & 0.039 & 0.0074 & $<0.0050$ \\
\hline 16 & $<0.010$ & $<0.20$ & $<0.0050$ & $<0.010$ & $<0.025$ & 0.015 & $<0.0050$ \\
\hline 18 & $<0.010$ & $<0.20$ & $<0.0050$ & $<0.010$ & $<0.025$ & $<0.0030$ & $<0.0050$ \\
\hline 19 & 0.049 & $<0.20$ & $<0.0050$ & $<0.010$ & $<0.025$ & 0.018 & $<0.0050$ \\
\hline 21 & $<0.010$ & $<0.20$ & $<0.0050$ & $<0.010$ & $<0.025$ & $<0.0030$ & $<0.0050$ \\
\hline 22 & $<0.010$ & $<0.20$ & $<0.0050$ & $<0.010$ & $<0.025$ & 0.020 & $<0.0050$ \\
\hline 23 & $<0.010$ & $<0.20$ & $<0.0050$ & $<0.010$ & 0.038 & $<0.0030$ & $<0.0050$ \\
\hline 24 & $<0.010$ & $<0.20$ & $<0.0050$ & $<0.010$ & $<0.025$ & $<0.0030$ & $<0.0050$ \\
\hline 25 & $<0.010$ & $<0.20$ & $<0.0050$ & $<0.010$ & $<0.025$ & $<0.0030$ & $<0.0050$ \\
\hline 26 & $<0.010$ & $<0.20$ & $<0.0050$ & $<0.010$ & $<0.025$ & 0.013 & $<0.0050$ \\
\hline 28 & $<0.010$ & $<0.20$ & $<0.0050$ & $<0.010$ & $<0.025$ & $<0.0030$ & $<0.0050$ \\
\hline 29 & $<0.010$ & $<0.20$ & $<0.0050$ & $<0.010$ & $<0.025$ & 0.025 & $<0.0050$ \\
\hline 30 & $<0.010$ & $<0.20$ & $<0.0050$ & $<0.010$ & 0.027 & $<0.0030$ & $<0.0050$ \\
\hline 32 & 0.013 & $<0.20$ & $<0.0050$ & $<0.010$ & $<0.025$ & 0.013 & $<0.0050$ \\
\hline 33 & $<0.010$ & $<0.20$ & $<0.0050$ & $<0.010$ & $<0.025$ & $<0.0030$ & $<0.0050$ \\
\hline 34 & $<0.010$ & $<0.20$ & $<0.0050$ & $<0.010$ & 0.042 & 0.0085 & $<0.0050$ \\
\hline 35 & $<0.010$ & $<0.20$ & $<0.0050$ & $<0.010$ & $<0.025$ & $<0.0030$ & $<0.0050$ \\
\hline 36 & $<0.010$ & $<0.20$ & $<0.0050$ & $<0.010$ & 0.11 & 0.0075 & $<0.0050$ \\
\hline 37 & $<0.010$ & $<0.20$ & $<0.0050$ & $<0.010$ & $<0.025$ & $<0.0030$ & $<0.0050$ \\
\hline $38^{(b)}$ & $<0.010$ & $<0.20$ & $<0.0050$ & $<0.010$ & $<0.025$ & 0.0076 & $<0.0050$ \\
\hline 39 & $<0.010$ & $<0.20$ & $<0.0050$ & $<0.010$ & 0.078 & 0.0077 & $<0.0050$ \\
\hline 40 & $<0.010$ & $<0.20$ & $<0.0050$ & $<0.010$ & $<0.025$ & $<0.0030$ & $<0.0050$ \\
\hline 41 & $<0.010$ & $<0.20$ & $<0.0050$ & $<0.010$ & $<0.025$ & $<0.0030$ & $<0.0050$ \\
\hline 56 & $<0.010$ & $<0.20$ & $<0.0050$ & $<0.010$ & $<0.025$ & $<0.0030$ & $<0.0050$ \\
\hline 55 & $<0.010$ & $<0.20$ & $<0.0050$ & $<0.010$ & 0.034 & $<0.0030$ & $<0.0050$ \\
\hline $\begin{array}{c}\text { Primary } \\
\text { Standard (c) }\end{array}$ & 0.05 & 2.0 & 0.005 & 0.1 & $1.0^{(d)}$ & $0.015^{(d)}$ & 0.05 \\
\hline
\end{tabular}


TABLE 18: Metals in Private Wells, 1993

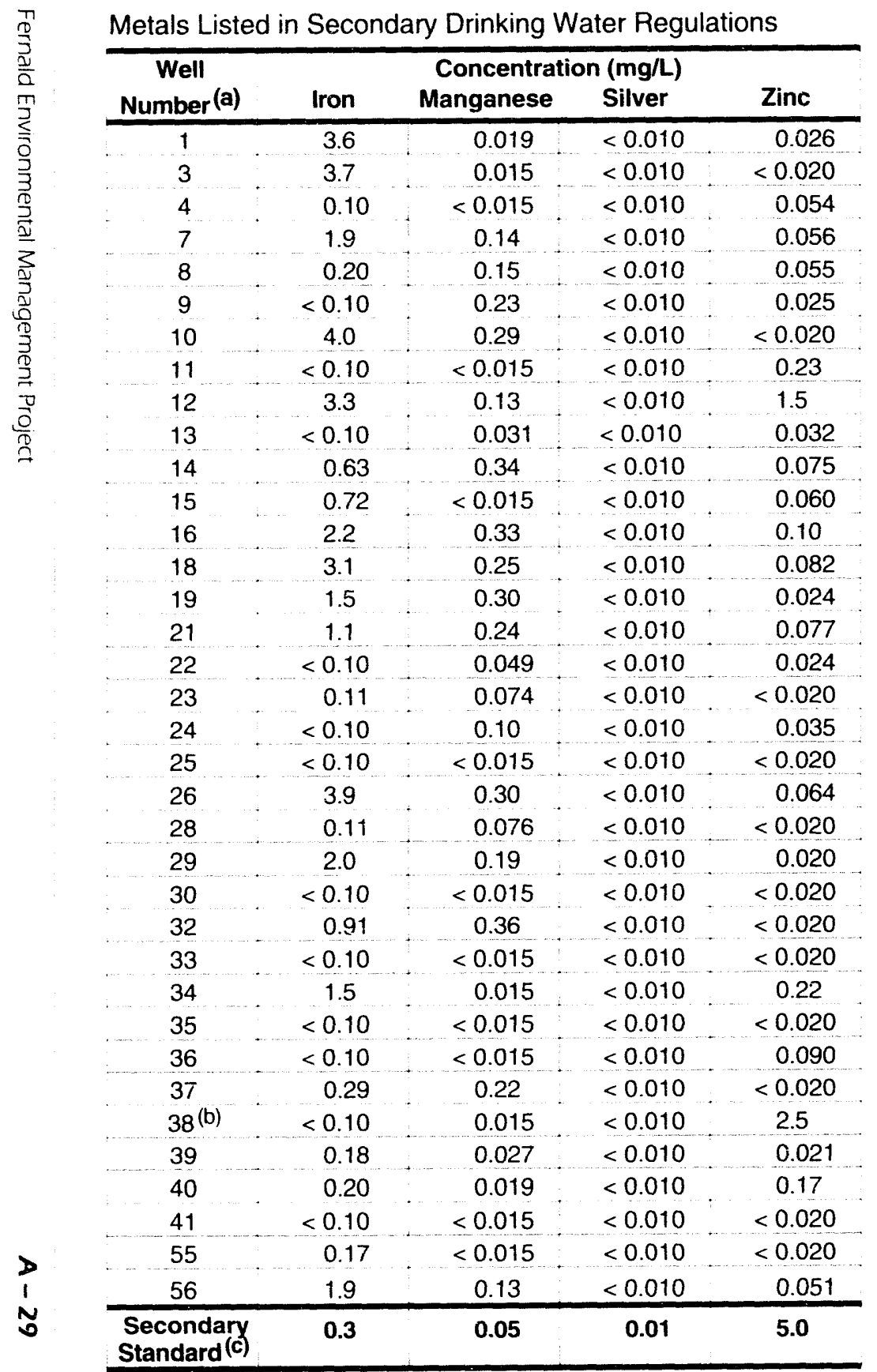


TABLE 18: Metals in Private Wells, 1993

w Metals Not Listed in Drinking Water Regulations

\begin{tabular}{|c|c|c|c|c|c|}
\hline \multirow{2}{*}{$\begin{array}{c}\text { Well } \\
\text { Number(a) }\end{array}$} & \multicolumn{5}{|c|}{ Concentration (mg/L) } \\
\hline & Calcium & Magnesium & Nickel & Potassium & Sodium \\
\hline 1 & 80 & 25 & $<0.040$ & $<5.0$ & 20 \\
\hline 3 & 78 & 25 & $<0.040$ & $<5.0$ & 35 \\
\hline 4 & 130 & 60 & $<0.040$ & $<5.0$ & 48 \\
\hline 7 & 110 & 32 & $<0.040$ & $<5.0$ & 9.3 \\
\hline 8 & 94 & 29 & $<0.040$ & $<5.0$ & 19 \\
\hline 9 & 73 & 27 & $<0.040$ & $<5.0$ & 30 \\
\hline 10 & 120 & 33 & $<0.040$ & $<5.0$ & 15 \\
\hline 11 & 77 & 23 & $<0.040$ & $<5.0$ & 10 \\
\hline 12 & 86 & 23 & $<0.040$ & $<5.0$ & 11 \\
\hline 13 & 91 & 25 & $<0.040$ & $<5.0$ & 21 \\
\hline 14 & 110 & 30 & $<0.040$ & 10 & 25 \\
\hline 15 & 97 & 26 & $<0.040$ & $<5.0$ & 18 \\
\hline 16 & 110 & 31 & $<0.040$ & $<5.0$ & 59 \\
\hline 18 & 100 & 26 & $<0.040$ & $<5.0$ & 13 \\
\hline 19 & 74 & 34 & $<0.040$ & 63 & 28 \\
\hline 21 & 96 & 24 & $<0.040$ & $<5.0$ & 10 \\
\hline 22 & 88 & 23 & $<0.040$ & $<5.0$ & 17 \\
\hline 23 & 88 & 25 & $<0.040$ & $<5.0$ & 6.1 \\
\hline 24 & 120 & 34 & $<0.040$ & $<5.0$ & 9.4 \\
\hline 25 & 110 & 31 & $<0.040$ & $<5.0$ & 9.2 \\
\hline 26 & 93 & 23 & $<0.040$ & $<5.0$ & 11 \\
\hline 28 & 89 & 25 & $<0.040$ & $<5.0$ & 6.0 \\
\hline 29 & 91 & 25 & $<0.040$ & $<5.0$ & 9.7 \\
\hline 30 & 86 & 24 & $<0.040$ & $<5.0$ & 14 \\
\hline 32 & 93 & 24 & $<0.040$ & 12 & 7.6 \\
\hline 33 & 98 & 26 & $<0.040$ & $<5.0$ & 14 \\
\hline 34 & 100 & 26 & $<0.040$ & $<5.0$ & 11 \\
\hline 35 & 120 & 32 & $<0.040$ & $<5.0$ & 33 \\
\hline 36 & 120 & 27 & $<0.040$ & $<5.0$ & 15 \\
\hline 37 & 140 & 36 & $<0.040$ & $<5.0$ & 8.3 \\
\hline $38^{(b)}$ & 46 & 10 & $<0.040$ & $<5.0$ & 1.3 \\
\hline 39 & 190 & 33 & $<0.040$ & $<5.0$ & 68 \\
\hline 40 & 140 & 30 & $<0.040$ & $<5.0$ & 22 \\
\hline 41 & 110 & 35 & $<0.040$ & $<5.0$ & 37 \\
\hline 55 & 12 & 31 & $<0.040$ & $<5.0$ & 9.1 \\
\hline 56 & 100 & 26 & $<0.040$ & $<5.0$ & 5.6 \\
\hline
\end{tabular}

(a) See Figure 36 on page 100 for well locations. One sample was collected from each well. All samples were taken during the month of July.

(b) Samples collected from a cistern.

(c) USEPA drinking water regulations taken from 40 CFR Part 141, National Interim Primary Drinking Water Regulations - Subpart B Maximum Contaminant Levels, July 1992, and from CFR Part 143, National Secondary Drinking Water Regulations - Section 143.3 Secondary Maximum Contaminant Levels.

(d) USEPA drinking water regulations taken from 40 CFR Part 141 National Interim Primary Drinking Water Regulations - Subpart I Control of Lead and Copper, July 1992. 
TABLE 19: Nonradioactive Substances above Primary Drinking Water Standards, 1993

\begin{tabular}{|c|c|c|c|c|}
\hline Substance & Well Location(a) & Sample Date & $\begin{array}{c}\text { Concentration } \\
\text { (mgiL) }\end{array}$ & $\begin{array}{c}\text { Primary Standard } \\
(\mathrm{mg} / \mathrm{L})^{(\mathrm{b})}\end{array}$ \\
\hline Antimony & 1332 Production Area & April 17 & 0.135 & 0.006 \\
\hline Antimony & 4013 Production Area & April 20 & 0.0792 & 0.006 \\
\hline Antimony & 1645 Waste Pit Area & April 17 & 0.0786 & 0.006 \\
\hline Antimony & 1080 Waste Pit Area & April 17 & 0.0771 & 0.006 \\
\hline Antimony & 1646 Waste Pit Area & April 17 & 0.0709 & 0.006 \\
\hline Antimony & 1230 Production Area & May 17 & 0.0704 & 0.006 \\
\hline Antimony & 1645 Waste Pit Area & April 17 & 0.0679 & 0.006 \\
\hline Antimony & 4013 Production Area & April 20 & 0.0662 & 0.006 \\
\hline Antimony & 1644 Waste Pit Area & April 17 & 0.0623 & 0.006 \\
\hline Antimony & 1080 Waste Pit Area & April 17 & 0.06160 & 0.006 \\
\hline Antimony & 1646 Waste Pit Area & April 17 & 0.0538 & 0.006 \\
\hline Antimony & 1240 Production Area & May 15 & 0.0517 & 0.006 \\
\hline Antimony & 2066 NW Corner of Fernald Site & April 7 & 0.0439 & 0.006 \\
\hline Antimony & 1361 Production Area & May 27 & 0.0305 & 0.006 \\
\hline Antimony & 1059 NW Offsite & September 29 & 0.0272 & 0.006 \\
\hline Antimony & 1189 Production Area & June 28 & 0.0156 & 0.006 \\
\hline Antimony & 1065 South of SWRB & May 4 & 0.0141 & 0.006 \\
\hline Antimony & 1941 South of SWRB & April 30 & 0.0132 & 0.006 \\
\hline Antimony & 1954 Southwest of SWRB & June 22 & 0.012 & 0.006 \\
\hline Antimony & 11085 Southwest of SWRB & June 16 & 0.0074 & 0.006 \\
\hline Antimony & 11032 Southwest of SWRB & June 30 & 0.0061 & 0.006 \\
\hline Arsenic & 1644 Waste Pit Area & April 17 & 0.313 & 0.050 \\
\hline Arsenic & 1644 Waste Pit Area & April 17 & 0.191 & 0.050 \\
\hline Arsenic & 3009 Paddys Run, South of Silos & June 7 & 0.186 & 0.050 \\
\hline Arsenic & 2094 South of Fernald Site & July 26 & 0.168 & 0.050 \\
\hline Arsenic & 2094 South of Fernald Site & July 26 & 0.161 & 0.050 \\
\hline Arsenic & 3066 NW Corner of Fernald Site & April 7 & 0.156 & 0.050 \\
\hline Arsenic & 3009 Paddys Run, South of Silos & June 7 & 0.15 & 0.050 \\
\hline Arsenic & 3679 NW Corner of Fernald Site & May 24 & 0.148 & 0.050 \\
\hline Arsenic & 3066 NW Corner of Fernald Site & April 7 & 0.145 & 0.050 \\
\hline Arsenic & 3679 NW Corner of Fernald Site & May 24 & 0.144 & 0.050 \\
\hline Arsenic & 2679 NW Corner of Fernald Site & May 24 & 0.136 & 0.050 \\
\hline Arsenic & 2679 NW Corner of Fernald Site & May 24 & 0.101 & 0.050 \\
\hline Arsenic & 1189 Production Area & June 28 & 0.101 & 0.050 \\
\hline
\end{tabular}


TABLE 19: Nonradioactive Substances above Primary Drinking Water Standards, 1993

\begin{tabular}{|c|c|c|c|c|}
\hline Substance & Well Location(a) & Sample Date & $\begin{array}{c}\text { Concentration } \\
(\mathrm{mg} / \mathrm{L})\end{array}$ & $\begin{array}{l}\text { Primary Standard } \\
(\mathrm{mg} / \mathrm{L})^{(\mathrm{b})}\end{array}$ \\
\hline Barium & 11229 North of Production Area & September 16 & 3.35 & 2.0 \\
\hline Barium & 1189 Production Area & June 28 & 2.26 & 2.0 \\
\hline Beryllium & 3009 Paddys Run, South of Silos & June 7 & 0.131 & 0.004 \\
\hline Beryllium & 3009 Paddys Run. South of Silos & June 7 & 0.125 & 0.004 \\
\hline Beryllium & 1719 NW of Production Area & July 7 & 0.0282 & 0.004 \\
\hline Beryllium & 11229 North of Production Area & September 16 & 0.0231 & 0.004 \\
\hline Beryllium & 2754 NE Corner of Fernald Site & July 22 & 0.0116 & 0.004 \\
\hline Beryllium & 1201 Production Area & June 29 & 0.0113 & 0.004 \\
\hline Beryllium & 1189 Production Area & June 28 & 0.0111 & 0.004 \\
\hline Beryllium & 1152 East of Production Area & June 11 & 0.01 & 0.004 \\
\hline Beryllium & 1214 Production Area & June 29 & 0.0099 & 0.004 \\
\hline Beryllium & 11085 Southwest of SWRB & June 16 & 0.0096 & 0.004 \\
\hline Beryllium & 1728 NW Corner of Fernald Site & July 24 & 0.0095 & 0.004 \\
\hline Beryllium & 11032 Southwest of SWRB & June 30 & 0.0061 & $0.0 \mathrm{C} 4$ \\
\hline Beryllium & 1161 Production Area & February 12 & 0.0050 & 0.004 \\
\hline Beryllium & 1148 Production Area & February 4 & 0.0046 & 0.004 \\
\hline Beryllium & 1359 Production Area & May 26 & 0.004 & 0.004 \\
\hline Cadmium & 3009 Paddys Run, South of Silos & June 7 & 0.165 & 0.005 \\
\hline Cadmium & 3009 Paddys Run, South of Silos & June 7 & 0.161 & 0.005 \\
\hline Cadmium & 2754 NE Corner of Fernald Site & July 22 & 0.127 & 0.005 \\
\hline Cadmium & 1189 Production Area & June 28 & 0.070 & 0.005 \\
\hline Cadmium & 2420 Production Area & July 15 & 0.0459 & 0.005 \\
\hline Cadmium & 2754 NE Corner of Fernald Site & July 22 & 0.0345 & 0.005 \\
\hline Cadmium & 1065 South of SWRB & May 4 & 0.034 & 0.005 \\
\hline Cadmium & 2420 Production Area & July 15 & 0.0333 & 0.005 \\
\hline Cadmium & 1201 Production Area & June 29 & 0.030 & 0.005 \\
\hline Cadmium & 1267 Production Area & May 16 & 0.0246 & 0.005 \\
\hline Cadmium & 1214 Production Area & June 29 & 0.021 & 0.005 \\
\hline Cadmium & 2754 NE Corner of Fernald Site & September 24 & 0.0205 & 0.005 \\
\hline Cadmium & 2733 SE Corner of Fernald Site & July 28 & 0.0197 & 0.005 \\
\hline Cadmium & 2733 SE Corner of Fernald Site & July 28 & 0.0191 & 0.005 \\
\hline Cadmium & 2171 East of Production Area & June 7 & 0.01690 & 0.005 \\
\hline Cadmium & 2417 East of Production Area & June 8 & 0.0168 & 0.005 \\
\hline Cadmium & 1281 Production Area & June 30 & 0.0155 & 0.005 \\
\hline Cadmium & 2424 NE of Production Area & July 28 & 0.0155 & 0.005 \\
\hline
\end{tabular}


TABLE 19: Nonradioactive Substances above Primary Drinking Water Standards, 1993

\begin{tabular}{|c|c|c|c|c|}
\hline Substance & Well Location(a) & Sample Date & $\begin{array}{c}\text { Concentration } \\
\text { (mg/L) }\end{array}$ & $\begin{array}{c}\text { Primary Standard } \\
(\mathrm{mg} / \mathrm{L})^{(\mathrm{b})}\end{array}$ \\
\hline Cadmium & 1363 Production Area & July 1 & 0.0141 & 0.005 \\
\hline Cadmium & 3024 North of Waste Pit Area & April 12 & 0.0135 & 0.005 \\
\hline Cadmium & 2426 East of Production Area & July 28 & 0.0115 & 0.005 \\
\hline Cadmium & 1025 Waste Pit Area & July 7 & 0.0113 & 0.005 \\
\hline Cadmium & 2432 SE of Production Area & July 28 & 0.0102 & 0.005 \\
\hline Cadmium & 1230 Production Area & May 17 & 0.0097 & 0.005 \\
\hline Cadmium & 2432 SE of Production Area & July 28 & 0.0096 & 0.005 \\
\hline Cadmium & 2431 SE of Production Area & September 14 & 0.0095 & 0.005 \\
\hline Cadmium & 2429 East of Production Area & September 21 & 0.0094 & 0.005 \\
\hline Cadmium & 1357 Production Area & May 28 & 0.0090 & 0.005 \\
\hline Cadmium & 2417 East of Production Area & June 8 & 0.0083 & 0.005 \\
\hline Cadmium & 1719 NW of Production Area & July 7 & 0.0082 & 0.005 \\
\hline Cadmium & 1291 Production Area & June 30 & 0.0082 & 0.005 \\
\hline Cadmium & 1345 Production Area & May 28 & 0.0079 & 0.005 \\
\hline Cadmium & 1353 Production Area & July 7 & 0.0072 & 0.005 \\
\hline Cadmium & 1354 Productiun Area & July 9 & 0.0070 & 0.005 \\
\hline Cadmium & 2426 East of Production Area & July 28 & 0.0065 & 0.005 \\
\hline Cadmium & 2417 East of Production Area & July 27 & 0.0065 & 0.005 \\
\hline Cadmium & 11071 Production Area & July 1 & 0.0061 & 0.005 \\
\hline Cadmium & 2432 SE of Production Area & September 15 & 0.0059 & 0.005 \\
\hline Cadmium & 1029 Silo Area & July 12 & 0.0056 & 0.005 \\
\hline Cadmium & 11032 Southwest of SWRB & June 30 & 0.0056 & 0.005 \\
\hline Cadmium & 1719 NW c: Production Area & July 7 & 0.0055 & 0.005 \\
\hline Cadmium & 1352 Production Area & May 28 & 0.0054 & 0.005 \\
\hline Cadmium & 2733 SE Corner of Fernald Site & September 17 & 0.0054 & 0.005 \\
\hline Cadmium & 2398 South Edge of Fernald Site & September 17 & 0.0053 & 0.005 \\
\hline Cadmium & 2011 Waste Pit Area & June 10 & 0.0053 & 0.005 \\
\hline Cadmium & 1281 Production Area & June 30 & 0.0052 & 0.005 \\
\hline Cadmium & 1218 Production Area & May 17 & 0.0051 & 0.005 \\
\hline Cadmium & 1034 Silo Area & July 12 & 0.0050 & 0.005 \\
\hline
\end{tabular}


TABLE 19: Nonradioactive Substances above Primary Drinking Water Standards, 1993

\begin{tabular}{|c|c|c|c|c|}
\hline Substance & Well Location ${ }^{(a)}$ & Sample Date & $\begin{array}{c}\text { Concentration } \\
\text { (mg/L) }\end{array}$ & $\begin{array}{c}\text { Primary Standard } \\
\text { (mg/L) (b) }\end{array}$ \\
\hline Chromium & 2754 NE of Production Area & July 22 & 7.710 & 0.1 \\
\hline Chromium & 1766 Waste Pit Area & June 24 & 2.750 & 0.1 \\
\hline Chromium & 2624 South of Fernald Site & May 25 & 1.110 & 0.1 \\
\hline Chromium & 11229 North of Production Area & September 16 & 0.820 & 0.1 \\
\hline Chromium & 1032 Silo Area & July 25 & 0.491 & 0.1 \\
\hline Chromium & 1182 Production Area & June 16 & 0.312 & 0.1 \\
\hline Chromium & 1728 NW Section of Fernald Site & July 24 & 0.283 & 0.1 \\
\hline Chromium & 3009 Paddys Run, South of Silos & June 7 & 0.278 & 0.1 \\
\hline Chromium & 3009 Paddys Run, South of Silos & June 7 & 0.262 & 0.1 \\
\hline Chromium & 1073 Waste Pit Area & July 16 & 0.261 & 0.1 \\
\hline Chromium & 1189 Production Area & June 28 & 0.261 & 0.1 \\
\hline Chromium & 1152 East of Production Area & June 11 & 0.260 & 0.1 \\
\hline Chromium & 11069 SW of Production Area & July 24 & 0.236 & 0.1 \\
\hline Chromium & 1201 Production Area & June 29 & 0.223 & 0.1 \\
\hline Chromium & 1031 Waste Pit Area & April 26 & 0.221 & 0.1 \\
\hline Chromium & 2754 NE of Production Area & September 24 & 0.213 & 0.1 \\
\hline Chromium & 1214 Production Area & June 29 & 0.202 & 0.1 \\
\hline Chromium & 11085 Southwest of SWRB & June 16 & 0.196 & 0.1 \\
\hline Chromium & 11032 Southwest of SWRB & June 30 & 0.167 & 0.1 \\
\hline Chromium & 2636 South Plume & May 25 & 0.155 & 0.1 \\
\hline Chromium & 2125 South Plume & May 20 & 0.151 & 0.1 \\
\hline Chromium & 1074 Waste Pit Area & April 13 & 0.145 & 0.1 \\
\hline Chromium & 1267 Production Area & May 16 & 0.144 & 0.1 \\
\hline Chromium & 41066 Production Area & July 25 & 0.142 & 0.1 \\
\hline Chromium & 1324 Production Area & July 10 & 0140 & 0.1 \\
\hline Chromium & 1179 Production Area & June 16 & 0.126 & 0.1 \\
\hline Chromium & 1324 Production Area & July 10 & 0.121 & 0.1 \\
\hline Chromium & 1359 Production Area & May 26 & 0.116 & 0.1 \\
\hline Chromium & 1073 Waste Pit Area & July 22 & 0.105 & 0.1 \\
\hline Cyanide & 3099 Paddys Run, South of Silos & June 7 & 0.36 & 0.2 \\
\hline Cyanide & 3099 Paddys Run, South of Silos & June 7 & 0.354 & 0.2 \\
\hline Mercury & 3099 Paddys Run, South of Silos & June 7 & 0.0139 & 0.002 \\
\hline Mercury & 3099 Paddys Run, South of Silos & June 7 & 0.0077 & 0.002 \\
\hline
\end{tabular}


TABLE 19: Nonradioactive Substances

above Primary Drinking Water Standards, 1993

\begin{tabular}{|c|c|c|c|c|}
\hline Substance & Well Location(a) & Sample Date & $\begin{array}{c}\text { Concentration } \\
(\mathrm{mg} / \mathrm{L})\end{array}$ & $\begin{array}{l}\text { Primary Standard } \\
(\mathrm{mg} / \mathrm{L})^{(\mathrm{b})}\end{array}$ \\
\hline Nickel & 2754 NE of Production Area & July 22 & 3.930 & 0.1 \\
\hline Nickel & 2754 NE of Production Area & September 24 & 2.0 & 0.1 \\
\hline Nickel & 11229 North of Production Area & September 16 & 1.47 & 0.1 \\
\hline Nickel & 2624 South Plume & May 25 & 0.621 & 0.1 \\
\hline Nickel & $27 \Xi 4$ NE of Production Area & July 22 & 0.589 & 0.1 \\
\hline Nickel & 1074 Waste Pit Area & April 13 & 0.536 & 0.1 \\
\hline Nickel & 1728 NW Section of Fernald Site & July 24 & 0.442 & 0.1 \\
\hline Nickel & 1074 Waste Pit Area & April 13 & 0.398 & 0.1 \\
\hline Nickel & 11069 SW of Production Area & July 24 & 0.361 & 0.1 \\
\hline Nickel & 1189 Production Area & June 28 & 0.352 & 0.1 \\
\hline Nickel & 11085 Southwest of SWRB & June 16 & 0.339 & 0.1 \\
\hline Nickel & 1267 Production Area & May 16 & 0.333 & 0.1 \\
\hline Nickel & 1152 East of Production Area & July 11 & 0.319 & 0.1 \\
\hline Nickel & 1201 Production Area & June 29 & 0.300 & 0.1 \\
\hline Nickel & 11032 Southwest of SWRB & June 30 & 0.243 & 0.1 \\
\hline Nickel & 1145 Production Area & June 23 & 0.206 & 0.1 \\
\hline Nickel & 1214 Production Area & June 29 & 0.202 & 0.1 \\
\hline Nickel & 1031 Waste Pit Area & April 26 & 0.201 & 0.1 \\
\hline Nickel & 1182 Production Area & June 16 & 0.185 & 0.1 \\
\hline Nickel & 1149 Production Area & February 3 & 0.144 & 0.1 \\
\hline Nickel & 3009 Paddys Run, South of Silos & June 7 & 0.137 & 0.1 \\
\hline Nickel & 1941 South of SWRB & May 28 & 0.136 & 0.1 \\
\hline Nickel & 2560 South of Fernald, near SR128 & May 15 & 0.135 & 0.1 \\
\hline Nickel & 3009 Paddys Run, South of Silos & June 7 & 0.131 & 0.1 \\
\hline Nickel & 1359 Production Area & May 26 & 0.130 & 0.1 \\
\hline Nickel & 1246 Production Area & July 22 & 0.128 & 0.1 \\
\hline Nickel & 1954 Southwest of SWRB & June 22 & 0.127 & 0.1 \\
\hline Nickel & 1952 NW Corner of Production Area & May 15 & 0.118 & 0.1 \\
\hline Nickel & 41066 Production Area & July 25 & 0.117 & 0.1 \\
\hline Nickel & 1942 South of SWRB & May 28 & 0.116 & 0.1 \\
\hline Nickel & 1110 Production Area & June 10 & 0.110 & 0.1 \\
\hline Nickel & 1179 Production Area & June 16 & 0.101 & 0.1 \\
\hline Nickel & 1317 Production Area & June 15 & 0.101 & 0.1 \\
\hline
\end{tabular}


TABLE 19: Nonradioactive Substances above Primary Drinking Water Standards, 1993

\begin{tabular}{|c|c|c|c|c|}
\hline Substance & Well Location(a) & Sample Date & $\begin{array}{c}\text { Concentration } \\
\text { (mg/L) }\end{array}$ & $\begin{array}{l}\text { Primary Standard } \\
\text { (mg/L) })^{(b)}\end{array}$ \\
\hline Selenium & 3009 Paddys Run, South of Silos & June 7 & 0.192 & 0.050 \\
\hline Selenium & 3009 Paddys Run, South of Silos & June 7 & 0.189 & 0.050 \\
\hline Selenium & 2754 NE of Production Area & July 22 & 0.0563 & 0.050 \\
\hline Thallium & 3009 Paddys Run, South of Silos & June 7 & 0.094 & 0.002 \\
\hline Thallium & 3009 Paddys Run, South of Silos & June 7 & 0.0895 & 0.002 \\
\hline Thallium & 1025 Waste Pit Area & July 7 & 0.006 & 0.002 \\
\hline Thallium & 2034 Silo Area & June 14 & 0.0022 & 0.002 \\
\hline Thallium & 1733 SE Corner of Fernald Site & July 30 & 0.0020 & 0.002 \\
\hline Benzene & 2639 South of New Haven Road & March 29 & 0.011 & 0.005 \\
\hline Benzene & 1196 Production Area & October 27 & 0.0050 & 0.005 \\
\hline Carbon Tetrachloride & 1149 Production Area & February 3 & 0.021 & 0.005 \\
\hline Carbon Tetrachloride & 11092 Production Area & August 6 & 0.0050 & 0.005 \\
\hline 1,2-Dichloroethane & 1149 Production Area & February 3 & 0.072 & 0.005 \\
\hline 1,2-Dichloroethane & 1148 Production Area & February 3 & 0.068 & 0.005 \\
\hline 1,2- Dichloroethane & 1145 Production Area & June 17 & 0.061 & 0.005 \\
\hline 1,2-Dichloroethane & 1509 Fire Training Facility & June 2 & 0.011 & 0.005 \\
\hline 1,2-Dichloropropane & 1196 Production Area & October 27 & 0.0050 & 0.005 \\
\hline Ethylbenzene & 2639 South of New Haven Road & March 29 & 1.6 & 0.7 \\
\hline Toluene & 2639 South of New Haven Road & March 29 & 1.6 & 1.0 \\
\hline 1,1,1-Trichloroethane & 1509 Fire Training Facility & June 2 & 5.9 & 0.20 \\
\hline 1,1,1-Trichloroethane & 1287 Production Area & May 25 & 0.31 & 0.20 \\
\hline 1,1,1-Trichloroethane & 1145 Production Area & June 17 & 0.27 & 0.20 \\
\hline 1,1,1-Trichloroethane & 1283 Production Area & May 25 & 0.20 & 0.20 \\
\hline 1,1,2-Trichloroethane & 1196 Production Area & October 27 & 0.0050 & 0.005 \\
\hline Vinyl Chloride & 11096 Production Area & August 5 & 0.12 & 0.002 \\
\hline Vinyl Chloride & 11098 Production Area & August 7 & 0.031 & 0.002 \\
\hline
\end{tabular}

(a) See figures 41 through 44 on pages 109 through 112 for well locations.

(b) USEPA drinking water regulations taken from 40 CFR Part 141, National Uranium Primary Drinking Water Regulations - Subpart B - Maximum Contaminant Levels, July 1984 
TABLE 20: Summary of Radiation Dose(a)

\begin{tabular}{|c|c|c|c|}
\hline Type of Dose & $\operatorname{Dose}^{(b)}$ & Standard (c) & $\begin{array}{c}\text { Percent } \\
\text { of Standard }\end{array}$ \\
\hline I. Individual & mrem $(d)$ & mrem(d) & \\
\hline $\begin{array}{l}\text { A. Maximum individual dose from air emissions, } \\
\text { excluding radon }(\mathrm{e})\end{array}$ & 0.016 & 10 & 0.16 \\
\hline \multicolumn{4}{|l|}{ B. ingestion $(f)$} \\
\hline $\begin{array}{l}\text { Produce ( } 204 \mathrm{~kg} / \mathrm{year} \text { or } 449 \text { pounds/year) } \\
\text { and milk }\end{array}$ & 0.01 & 100 & 0.01 \\
\hline $\begin{array}{l}\text { Well water } \\
\text { ( } 2 \text { Lday or } 0.5 \text { gallons/day) }\end{array}$ & 0.7 & 100 & 0.7 \\
\hline $\begin{array}{l}\text { Great Miami River fish } \\
(4.4 \mathrm{~kg} / \text { year or } 10 \text { pounds/year })\end{array}$ & 0.01 & 100 & 0.01 \\
\hline C. Direct radiation $(g)$ & 0.0 & 100 & 0.0 \\
\hline $\begin{array}{l}\text { D. Radon } \\
\text { Maximum dose to public at the site } \\
\text { fenceline } 8,760 \text { hrs/year }\end{array}$ & 450 & (h) & \\
\hline II. $80 \mathrm{~km}$ (50 miles) Population Dose $(e)$ & person-rem & & \\
\hline $\begin{array}{l}\text { Total collective dose equivalent from air } \\
\text { emissions excluding radon for } 2.740 .000 \\
\text { people living within } 80 \mathrm{~km} \text { (50 miles) }\end{array}$ & 0.3 & (h) & \\
\hline \multicolumn{4}{|l|}{ III. Other Sources of Dose ${ }^{(i)}$} \\
\hline A. Natural radioactivity & mrem/year & & \\
\hline 1. Radon in homes & 200 & & \\
\hline $\begin{array}{l}\text { 2. Other natural background radiation: cosmic } \\
\text { radiation plus natural terrestrial isotopes. } \\
\text { both external and internal. }\end{array}$ & 100 & & \\
\hline 3. Well water in Fernald site area & 0.4 & & \\
\hline B. Medical diagnosis $($ ) & 50 & & \\
\hline C. Consumer products & 10 & & \\
\hline D. Atmospheric weapons tests & 4.6 & & \\
\hline
\end{tabular}

(a) Including dose from all radionuclides listed in Table 21.

(b) The effective dose is the weighted sum of doses delivered to the individual organs of the body. Effective doses are comparable to whole body dose equivalents when considering the effects and risks of low-level radiation doses.

(c) Standards are as included in DOE Order 5400.5., "Radiation Protection of the Public and Environment." Also incorporated are the air emission dose standards of regulation 40 CFR 61, Subpart H (NESHAP).

(d) To obtain mSv, multiply mrem by 0.01

(e) Effective dose equivalent received as a result of 1993 estimated emissions

(f) Fifty-year committed dose equivalents based on environmental measurements of uranium in produce, milk, water, and fish.

(g) Whole body dose calculated from highest measurement along the Fernald site fenceline, using environmental thermoluminescent dosimeters corrected for background.

(h) There are no applicable standards.

(i) From NCRP-93. "lonizing Radiation Exposure of the Population of the United States."

(i) Medical dose estimates are population averages and will not necessarily be applicable to each individuai. 
TABLE 21: Estimated Airborne Emissions for the Fernald Site, 1993

$\underset{\infty}{\infty}$

\begin{tabular}{|c|c|c|c|c|}
\hline \multirow{2}{*}{ Radionuclide } & \multirow{2}{*}{ Total Curies } & \multirow{2}{*}{ Measured Curies (a) } & \multicolumn{2}{|c|}{ Estimated Curies $(b)$} \\
\hline & & & Waste Pit $5(c)$ & Remaining Sources (d) \\
\hline Uranium-234 & 0.000056 & 0.00000012 & 0.0000019 & 0.000054 \\
\hline Uranium-235 & 0.0000029 & 0.000000012 & 0.000000078 & 0.00000028 \\
\hline Uranium-236 & 0.0000022 & (e) & 0.00000019 & 0.0000020 \\
\hline Uranium-238 & 0.000061 & 0.00000010 & 0.0000014 & 0.000069 \\
\hline Radium-226 & 0.0000012 & (e) & 0.0000012 & 0.000000046 \\
\hline Radium-228 & 0.00000033 & (e) & 0.00000015 & 0.00000018 \\
\hline Thorium-228 & 0.000013 & 0.000000043 & 0.00000020 & 0.000013 \\
\hline Thorium-230 & 0.000023 & 0.000000019 & 0.000022 & 0.0000013 \\
\hline Thorium-232 & 0.00000045 & (e) & 0.00000015 & 0.00000030 \\
\hline Thorium-234 & 0.00028 & 0.0000000025 & 0.0000014 & 0.00028 \\
\hline
\end{tabular}
(a) Measured emissions are from a single laboratory stack that was updated in 1993.
(b) There were no nonroutine radiological releases during 1993.
(c) Fugitive emissions from the waste pits.
(d) Includes three unmonitored stacks, two building vents, laboratory hoods, and the cooling tower.
(e) No analyses were conducted for these radionuclides. 


\begin{tabular}{|c|c|c|c|c|c|}
\hline \multirow{2}{*}{$\begin{array}{c}\text { Fenceline } \\
\text { Locations }(a)\end{array}$} & \multicolumn{5}{|c|}{ Radon Concentration (pCi/L) ${ }^{(b)}$} \\
\hline & $\begin{array}{l}\text { First } \\
\text { Quarter }\end{array}$ & $\begin{array}{l}\text { Second } \\
\text { Quarter }\end{array}$ & $\begin{array}{l}\text { Third } \\
\text { Quarter }\end{array}$ & $\begin{array}{l}\text { Fourth } \\
\text { Quarter }\end{array}$ & Average \\
\hline AMS 1 & 0.10 & 0.13 & (c) & (c) & 0.12 \\
\hline AMS 2 & 0.10 & 0.13 & 0.58 & 0.95 & 0.44 \\
\hline AMS 4 & 0.10 & 0.13 & 0.68 & 1.2 & 0.52 \\
\hline AMS 6 & 0.10 & 0.03 & 0.78 & 0.95 & 0.47 \\
\hline AMS 7 & 0.30 & 0.23 & 0.58 & 1.0 & 0.54 \\
\hline A & 0.40 & 0.03 & 0.28 & 1.2 & 0.49 \\
\hline B & 0.60 & 0.13 & 0.58 & 1.0 & 0.59 \\
\hline $\mathrm{C}$ & 0.70 & 0.23 & 0.28 & 0.95 & 0.54 \\
\hline $\mathrm{D}$ & 0.80 & 0.33 & 0.58 & 1.2 & 0.74 \\
\hline$E$ & 0.50 & 0.23 & 0.48 & 1.2 & 0.62 \\
\hline$F$ & 0.30 & 0.23 & 1.6 & 0.55 & 0.67 \\
\hline G & (d) & 0.33 & 0.78 & 1.0 & 0.72 \\
\hline $\mathrm{H}$ & 0.60 & 0.03 & 0.48 & 0.75 & 0.46 \\
\hline 1 & 1.2 & 0.13 & 0.48 & 0.95 & 0.69 \\
\hline$J$ & 1.0 & 0.03 & 0.58 & 0.75 & 0.59 \\
\hline$K$ & 1.5 & 0.13 & 0.68 & 0.95 & 0.82 \\
\hline$L$ & 0.40 & 0.43 & 1.2 & 085 & 0.72 \\
\hline$M$ & 1.6 & 0.23 & 1.1 & (d) & 0.97 \\
\hline$N$ & 1.6 & 0.03 & 0.98 & 0.85 & 0.87 \\
\hline 0 & 1.5 & 0.23 & 1.5 & 0.75 & 0.99 \\
\hline$P$ & 0.10 & 0.33 & 1.1 & (d) & 0.50 \\
\hline $\begin{array}{l}\text { Quarterly } \\
\text { Averages }\end{array}$ & 0.68 & 0.18 & 0.76 & 0.96 & 0.63 \\
\hline
\end{tabular}




\begin{tabular}{|c|c|c|c|c|c|}
\hline \multirow{2}{*}{$\begin{array}{l}\text { Background } \\
\text { Locations }^{(a)}\end{array}$} & \multicolumn{5}{|c|}{ Radon Concentration ( $\mathrm{pCi/L)}(\mathrm{b})$} \\
\hline & $\begin{array}{l}\text { First } \\
\text { Quarter }\end{array}$ & $\begin{array}{l}\text { Second } \\
\text { Quarter }\end{array}$ & $\begin{array}{l}\text { Third } \\
\text { Quarter }\end{array}$ & $\begin{array}{l}\text { Fourth } \\
\text { Quarter }\end{array}$ & Average \\
\hline Bkgd 1 & 0.40 & 0.13 & 1.2 & 2.2 & 0.97 \\
\hline Bkgd 2 & 0.40 & 0.13 & 1.3 & 2.0 & 0.97 \\
\hline AMS 15 & 0.40 & 0.23 & 1.5 & 1.6 & 0.92 \\
\hline AMS 16 & 0.50 & 0.13 & 1.3 & 1.8 & 0.94 \\
\hline
\end{tabular}

\begin{tabular}{llllll}
\hline $\begin{array}{c}\text { Other } \\
\text { Locations }(\mathbf{a})\end{array}$ & \multicolumn{7}{c}{ Radon Concentration $\mathbf{( p C i / L )}(\mathbf{b})$} \\
& $\begin{array}{l}\text { First } \\
\text { Quarter }\end{array}$ & $\begin{array}{l}\text { Second } \\
\text { Quarter }\end{array}$ & $\begin{array}{l}\text { Third } \\
\text { Quarter }\end{array}$ & $\begin{array}{l}\text { Fourth } \\
\text { Quarter }\end{array}$ & Average \\
\hline AMS 1A & (c) & (c) & 0.48 & 0.85 & 0.67 \\
\hline AMS 8 & 0.10 & 0.03 & 0.38 & 0.95 & 0.37 \\
\hline AMS 9 & 0.50 & 0.13 & 0.78 & 1.4 & 0.69 \\
\hline AMS 10 & 0.30 & 0.03 & 0.58 & $($ d) & 0.30 \\
\hline AMS 11 & 0.30 & 0.13 & 0.48 & 0.75 & 0.42 \\
\hline AMS 12 & 0.10 & 0.03 & 0.78 & 0.65 & 0.39 \\
\hline AMS 13 & 0.10 & 0.03 & 0.28 & 1.2 & 0.42 \\
\hline RES 1 & 0.30 & 0.03 & 0.78 & 0.85 & 0.49 \\
\hline RES 2 & 0.30 & 0.33 & 0.68 & 1.23 & 0.62 \\
\hline RES 3 & 0.30 & 0.53 & 0.78 & 1.0 & 0.67 \\
\hline Quarterly & 0.26 & 0.14 & 0.61 & 0.89 & 0.50 \\
Averages & & & & & \\
\hline
\end{tabular}
(a) See Figure 48 on page 132 for locations.
(b) Corrected for instrument background except for the first quarter.
(c) Fenceline monitoring location AMS 1 was relocated to AMS 1A for the third and fourth quarters of 1993.
(d) Data invalidated due to instrument error. 
TABLE 23: DOE Quality Assessment Program for Environmental

Radionuclide Analyses Fernald Site Laboratories

Performance Results, 1993

\begin{tabular}{|l|c|c|c|c|c|}
\hline $\begin{array}{c}\text { Sample } \\
\text { Type }\end{array}$ & $\begin{array}{c}\text { Sample } \\
\text { Number }\end{array}$ & Units & $\begin{array}{c}\text { Uranium Values } \\
\text { Site Laboratories }\end{array}$ & EML (a) & Site Value/EML Value \\
\hline Air Filter & $93-09$ & $\mu \mathrm{g} / \mathrm{Filter}$ & 4.9 & 5.4 & 0.91 \\
\hline Soil & $93-09$ & $\mu \mathrm{g} / \mathrm{g}$ & 1.3 & 2.0 & 0.64 \\
\hline
\end{tabular}

(a) DOE's Environmental Measurements Laboratory (EML). 
TABLE 24: USEPA Quality Assurance Program for Wastewater Analyses Fernald Site Laboratories Performance Evaluation, 1993 (a)

\begin{tabular}{|c|c|c|c|c|c|}
\hline Parameter & Units(b) & $\begin{array}{l}\text { Site } \\
\text { Laboratories }\end{array}$ & True $(c)$ & $\begin{array}{c}\text { USEPA } \\
\text { Acceptance } \\
\text { Limits (d) }\end{array}$ & $\begin{array}{c}\text { USEPA } \\
\text { Performance } \\
\text { Evaluation (e) }\end{array}$ \\
\hline Chromium & $\mu g / L$ & 460 & 460 & $380-530$ & ACCEPTABLE \\
\hline Copper & $\mu g / L$ & 460 & 410 & $360-460$ & ACCEPTABLE \\
\hline Lead & $\mu g / L$ & 340 & 450 & $390-510$ & UNACCEPTABLE \\
\hline Nickel & $\mu g / L$ & 1.300 & 1,300 & $1,200-1,400$ & ACCEPTABLE \\
\hline $\mathrm{pH}$ & S.U. & 6.1 & 6.1 & $6.0-6.2$ & ACCEPTABLE \\
\hline Total Suspended Solids & $\mathrm{mg} / \mathrm{L}$ & 33 & 33 & $24-35$ & ACCEPTABLE \\
\hline Oil \& Grease & $\mathrm{mg}^{\prime} \mathrm{L}$ & 27 & 32 & $14-28$ & ACCEPTABLE \\
\hline Ammonia - Nitrogen & $\mathrm{mg} / \mathrm{L}$ & 9.5 & 9.8 & $7.8-12$ & ACCEPTABLE \\
\hline Nitrate - Nitrogen & $\mathrm{mg} / \mathrm{L}$ & 7.2 & 7.1 & $5.7-8.4$ & ACCEPTABLE \\
\hline Carbonaceous BOD & $\mathrm{mg} / \mathrm{L}$ & 14 & 20 & $6.3-32$ & ACCEPTABLE \\
\hline 5 Day BOD & $\mathrm{mg} / \mathrm{L}$ & 24 & 22 & $12-32$ & ACCEPTABLE \\
\hline Total Cyanide & $\mathrm{mg} / \mathrm{L}$ & 0.10 & 0.13 & $0.082-0.17$ & ACCEPTABLE \\
\hline
\end{tabular}

(a) USEPA Discharge Monitoring Report (DMR) Quality Assurance (QA) Program. The Fernald site, along with all other National Pollutant Discharge Elimination Systems (NPDES) permit holders, is required to participate in these annual laboratory performance evaluation studies (Section 308[a] of the Clean Water Act).

(b) S.U. stands for standard units.

(c) Actual parameter concentrations established by USEPA based on theoretical calculations or a reference value when necessary.

(d) Laboratory measured values which fall within this range are considered acceptable by USEPA.

(e) USEPA DMR-QA Study Number 013 conducted during 1993. 
TABLE 25: Proficiency Environmental Testing Quality Assurance Program for Water Analyses, 1993

Summary of Performance of the Fernald Site's Laboratories

\begin{tabular}{|c|c|c|c|c|c|c|c|c|c|c|c|}
\hline \multirow{3}{*}{$\begin{array}{c}\text { Parameter } \\
\text { Ammonia-Nitrogen }\end{array}$} & \multirow{3}{*}{$\frac{\text { Units }}{\mathrm{mg} / \mathrm{L}}$} & \multirow{3}{*}{$\frac{\begin{array}{c}\text { Number } \\
\text { of } \\
\text { Analyses }\end{array}}{16}$} & \multirow{2}{*}{\multicolumn{2}{|c|}{$\begin{array}{l}\text { Range } \\
\text { of True } \\
\text { Values }\end{array}$}} & \multicolumn{3}{|c|}{ Percent Recovery(a) } & \multicolumn{3}{|c|}{$\begin{array}{l}\text { Deviations } \\
\text { from Mean (b) }\end{array}$} & \multirow{3}{*}{$\begin{array}{c}\begin{array}{c}\text { Percentage } \\
\text { Acceptable }^{(c)}\end{array} \\
94\end{array}$} \\
\hline & & & & & \multirow{2}{*}{\multicolumn{2}{|c|}{$\begin{array}{ll}\text { Min. } & \text { Max. } \\
57 & 110\end{array}$}} & \multirow{2}{*}{$\frac{\text { Avg. }}{91}$} & Min. & Max. & Avg. & \\
\hline & & & 0.19 & -9.2 & & & & 0.002 & 4.5 & 0.86 & \\
\hline $\begin{array}{l}\text { Biochemical Oxygen } \\
\text { Demand }\end{array}$ & $\mathrm{mg} / \mathrm{L}$ & 18 & 6.7 & -290 & 88 & 120 & 100 & 0.063 & 1.1 & 0.50 & 100 \\
\hline Calcium & $\mathrm{mg} / \mathrm{L}$ & 18 & 2.3 & -56 & 93 & 100 & 98 & 0.094 & 0.76 & 0.35 & 100 \\
\hline Chloride & $\mathrm{mg} / \mathrm{L}$ & 20 & 20 & -150 & 93 & 120 & 100 & 0.031 & 2.7 & 0.81 & 90 \\
\hline Fluoride & $\mathrm{mg} / \mathrm{L}$ & 18 & 0.060 & -14 & 92 & 150 & 100 & 0.018 & 2.2 & 0.44 & 100 \\
\hline Magnesium & $\mathrm{mg} / \mathrm{L}$ & 18 & 1.9 & -24 & 91 & 100 & 96 & 0.022 & 0.95 & 0.48 & 100 \\
\hline Nitrate-Nitrogen & $\mathrm{mg} / \mathrm{L}$ & 16 & 0.35 & -9.8 & 92 & 100 & 99 & 0.017 & 2.8 & 0.50 & 94 \\
\hline Oil \& Grease & $\mathrm{mg} / \mathrm{L}$ & 16 & 2.1 & -45 & 89 & 120 & 110 & 0.005 & 2.1 & 0.76 & 100 \\
\hline Potassium & $\mathrm{mg} / \mathrm{L}$ & 18 & 2.6 & -79 & 92 & 110 & 100 & 0.25 & 2.4 & 0.81 & 100 \\
\hline Sodium & $\mathrm{mg} / \mathrm{L}$ & 18 & 22 & -140 & 95 & 110 & 100 & 0.021 & 2.6 & 0.56 & 94 \\
\hline Sulfate & $\mathrm{mg} / \mathrm{L}$ & 20 & 12 & -150 & 78 & 150 & 100 & 0.12 & 4.5 & 1.5 & 85 \\
\hline Total Suspended Solids & $\mathrm{mg} / \mathrm{L}$ & 16 & 24 & -330 & 83 & 100 & 92 & 0.004 & 1.5 & 0.75 & 100 \\
\hline $\mathrm{pH}$ & S.U. & 18 & 2.6 & -9.6 & 98 & 100 & 100 & 0.007 & 0.92 & 0.50 & 100 \\
\hline Arsenic & $\mu g / L$ & 18 & 19 & -470 & 72 & 110 & 96 & 0.32 & 2.9 & 1.3 & 83 \\
\hline Barium & $\mu g / L$ & 18 & 180 & $-2,500$ & 9.6 & 100 & 93 & 0.014 & 17 & 1.3 & 94 \\
\hline Cadmium & $\mu g / L$ & 18 & 24 & -240 & 100 & 110 & 100 & 0.051 & 1.2 & 0.43 & 10 \\
\hline Chromium (Total) & $\mu \mathrm{g} / \mathrm{L}$ & 18 & 22 & -290 & 96 & 110 & 100 & 0.040 & 1.1 & 0.29 & 100 \\
\hline Chromium (Hexavalent) & $\mu g / L$ & 13 & 0.022 & -0.42 & 86 & 110 & 100 & 0.037 & 1.7 & 0.51 & 100 \\
\hline Copper & $\mu \mathrm{g} / \mathrm{L}$ & 18 & 30 & -270 & 62 & 110 & 98 & 0.079 & 4.6 & 1.3 & 100 \\
\hline Iron & $\mu g / L$ & 18 & 42 & -780 & 94 & 110 & 100 & 0.002 & 1.1 & 0.48 & 89 \\
\hline Lead & $\mu g / L$ & 18 & 33 & -480 & 10 & 1,500 & 170 & 0.048 & 140 & 9.0 & 100 \\
\hline Manganese & $\mu g / L$ & 18 & 28 & -480 & 97 & 110 & 100 & 0.009 & 1.6 & 0.30 & 89 \\
\hline Nickel & $\mu \mathrm{g} / \mathrm{L}$ & 18 & 27 & -290 & 92 & 110 & 100 & 0.13 & 1.2 & 0.54 & 100 \\
\hline Selenium & $\mu \mathrm{g} / \mathrm{L}$ & 18 & 14 & -200 & 76 & 110 & 96 & 0.048 & 1.5 & 0.44 & 100 \\
\hline Silver & $\mu g / L$ & 18 & 21 & -380 & 940 & 100 & 100 & 0.033 & 0.82 & 0.33 & 100 \\
\hline Uranium & $\mu g / L$ & 18 & 80 & -900 & 1.00 & 130 & 98 & 0.099 & 37 & 4.1 & 83 \\
\hline Zinc & $\mu g / L$ & 18 & 24 & -240 & 77 & 120 & 97 & 0.030 & 1.8 & 0.64 & 100 \\
\hline Total & & 477 & & & & & & & & & 96 \\
\hline
\end{tabular}


(a) Percent recovery is the site's measured value, divided by the true parameter concentration, multiplied by 100 .

(b) The standard deviation indicates the closeness of the site's measurement result to the mean value reported by Analytical Products Group, Inc., which conducts the testing program. The standard deviation would be 0.00 if the site's result and the mean value were exactly the same. The mean value is calculated from the results obtained by all laboratories participating in the control program. Any measurement results which are significantly different from the true parameter concentration or statistically different from the majority of results obtained by the other laboratories are not included in evaluating the mean value.

(c) This is the percentage of the site's measurement results for each parameter which met the USEPA "Acceptable" criteria of being within 2.58 standard deviations of the mean value. 


\begin{tabular}{|c|c|c|c|}
\hline \multirow{2}{*}{$\begin{array}{l}\text { TABLE 26: } \\
\text { Sampling } \\
\text { Location(a) }\end{array}$} & \multicolumn{3}{|c|}{$\begin{array}{l}\text { Fernald Site - ODH Uranium Sam } \\
\text { Groundwater Sampling Locations }\end{array}$} \\
\hline & Sampling & Concentrati & $(\mathrm{pCi} / \mathrm{L})^{(\mathrm{b})}$ \\
\hline Well 3 & September 29 & 0.07 & $<1.0$ \\
\hline Well 4 & January 22 & 1.2 & 1.5 \\
\hline Well 4 & February 26 & 1.0 & 1.9 \\
\hline Well 4 & March 25 & 1.2 & 1.4 \\
\hline Well 4 & April 22 & 1.4 & 2.0 \\
\hline Well 4 & May 27 & 1.3 & $<1.0$ \\
\hline Well 4 & June 30 & 0.95 & 1.9 \\
\hline Well 4 & July 22 & 1.3 & 1.4 \\
\hline Well 4 & August 26 & 1.1 & $<1.0$ \\
\hline Well 4 & October 28 & 1.1 & 2.0 \\
\hline Well 4 & November 30 & 1.4 & $<1.0$ \\
\hline Well 4 & December 26 & 1.2 & 2.0 \\
\hline Well 7 & May 27 & 0.47 & $<1.0$ \\
\hline Well 11 & January 22 & 0.95 & 1.0 \\
\hline Well 12 & February 26 & 120 & 1.1 \\
\hline Well 14 & January 22 & 1.3 & 1.4 \\
\hline Well 14 & February 26 & 1.6 & 2.5 \\
\hline Well 14 & March 25 & 1.7 & 1.3 \\
\hline Weli 14 & April 22 & 1.7 & 1.5 \\
\hline Well 14 & May 27 & 1.6 & $<1.0$ \\
\hline Well 14 & June 30 & 1.5 & 1.4 \\
\hline Well 14 & July 22 & 1.5 & $<1.0$ \\
\hline Well 14 & August 26 & 1.4 & $<1.0$ \\
\hline Well 14 & September 29 & 1.2 & $<1.0$ \\
\hline Well 14 & October 28 & 1.7 & $<1.0$ \\
\hline Well 14 & November 30 & 1.2 & 2.0 \\
\hline Well 14 & December 26 & 1.4 & 1.8 \\
\hline Well $15^{(c)}$ & January 22 & 140 & 170 \\
\hline Well $15^{(c)}$ & February 26 & 140 & 120 \\
\hline Well $15^{(\mathrm{c})}$ & March 25 & 160 & 130 \\
\hline
\end{tabular}

\begin{tabular}{|c|c|c|c|}
\hline \multirow{2}{*}{$\begin{array}{c}\text { Sampling } \\
\text { Location(a) }\end{array}$} & \multirow{2}{*}{$\begin{array}{c}\text { Sampling } \\
\text { Date }\end{array}$} & \multicolumn{2}{|c|}{ Concentration (pCi/L) ${ }^{(b)}$} \\
\hline & & Fernald Site & ODH \\
\hline Well 15(c) & April 22 & 140 & 160 \\
\hline Well $15^{\text {(c) }}$ & May 27 & 160 & 170 \\
\hline Well $15^{\text {(c) }}$ & June 30 & 180 & 150 \\
\hline Well $15^{\text {(c) }}$ & July 22 & 160 & 130 \\
\hline Well $15^{\text {(c) }}$ & August 26 & 160 & 110 \\
\hline Well $15^{(c)}$ & September 29 & 140 & 130 \\
\hline Well $15^{\text {(c) }}$ & October 28 & 160 & 150 \\
\hline Well $15^{\text {(c) }}$ & November 30 & 150 & 120 \\
\hline Well $15^{(c)}$ & December 26 & 170 & 130 \\
\hline Well 16 & August 26 & 0.47 & $<1.0$ \\
\hline Well 19 & January 22 & 0.07 & $<1.0$ \\
\hline Well 19 & February 26 & 0.07 & $<1.0$ \\
\hline Well 19 & March 25 & 0.07 & $<1.0$ \\
\hline Well 19 & April 22 & 0.07 & $<1.0$ \\
\hline Well 19 & May 27 & 0.07 & $<1.0$ \\
\hline Well 19 & June 30 & 0.07 & $<1.0$ \\
\hline Well 19 & July 22 & 0.07 & $<1.0$ \\
\hline Well 19 & August 26 & 0.07 & $<1.0$ \\
\hline Well 19 & September 29 & 0.07 & $<1.0$ \\
\hline Well 19 & October 28 & 0.07 & $<1.0$ \\
\hline Well 19 & November 30 & 0.20 & 4.0 \\
\hline Well 19 & December 26 & 0.07 & $<1.0$ \\
\hline Well 22 & March 25 & 0.68 & $<1.0$ \\
\hline Well 24 & December 26 & 0.41 & $<1.0$ \\
\hline Well 25 & April 22 & 0.34 & $<1.0$ \\
\hline Well 28 & October 28 & 0.61 & 1.0 \\
\hline Well 29 & June 30 & 1.6 & 1.4 \\
\hline Well 35 & July 22 & 1.2 & 1.3 \\
\hline Well 41 & November 30 & 0.61 & 1.0 \\
\hline
\end{tabular}


Surfacewater Sampling Locations

\begin{tabular}{|c|c|c|c|}
\hline \multirow{2}{*}{$\begin{array}{c}\text { Sampling } \\
\text { Location (a) }\end{array}$} & \multirow{2}{*}{$\begin{array}{c}\text { Sampling } \\
\text { Date }\end{array}$} & \multicolumn{2}{|c|}{ Concentration $(\mathrm{pCi} / \mathrm{L})^{(\mathrm{b})}$} \\
\hline & & Fernald Site & ODH \\
\hline$W 1$ & January 22 & 1.0 & 1.7 \\
\hline W1 & February 26 & 1.1 & 1.1 \\
\hline W1 & March 25 & 1.2 & 1.6 \\
\hline W1 & April 22 & 1.1 & $<1.0$ \\
\hline W1 & May 27 & 1.1 & $<1.0$ \\
\hline W1 & June 30 & 1.5 & $<1.0$ \\
\hline W1 & July 22 & 1.1 & $<1.0$ \\
\hline W1 & August 26 & 1.1 & $<1.0$ \\
\hline$W 1$ & September 29 & 0.81 & 1.0 \\
\hline W1 & October 28 & 1.1 & $<1.0$ \\
\hline W1 & November 30 & 1.4 & 2.0 \\
\hline W1 & December 23 & 1.1 & 1.7 \\
\hline W3 & January 22 & 1.4 & 2.1 \\
\hline W3 & February 26 & 1.4 & 1.5 \\
\hline W3 & March 25 & 1.1 & 2.1 \\
\hline W3 & April 22 & 1.2 & $<1.0$ \\
\hline W3 & May 27 & 1.0 & $<1.0$ \\
\hline W3 & June 30 & 1.5 & 1.3 \\
\hline W3 & July 22 & 1.4 & $<1.0$ \\
\hline W3 & August 26 & 1.0 & 3.0 \\
\hline W3 & September 29 & 0.89 & $<1.0$ \\
\hline W3 & October 28 & 1.2 & $<1.0$ \\
\hline W3 & November 30 & 1.5 & 1.2 \\
\hline W3 & December 23 & 1.3 & 2.0 \\
\hline W4 & January 22 & 1.1 & 1.6 \\
\hline W4 & February 26 & 1.4 & 1.6 \\
\hline W4 & March 25 & 1.1 & 1.4 \\
\hline W4 & April 22 & 1.3 & 1.0 \\
\hline W4 & May 27 & 1.0 & 1.8 \\
\hline W4 & June 30 & 1.4 & 1.3 \\
\hline W4 & July 22 & 1.5 & 1.3 \\
\hline
\end{tabular}

\begin{tabular}{|c|c|c|c|}
\hline \multirow{2}{*}{$\begin{array}{l}\text { Sampling } \\
\text { Location(a) }\end{array}$} & \multirow{2}{*}{$\begin{array}{c}\text { Sampling } \\
\text { Date }\end{array}$} & \multicolumn{2}{|c|}{ Concentration $(\mathrm{pCi} / \mathrm{L})^{(\mathrm{b})}$} \\
\hline & & Fernald Site & ODH \\
\hline W4 & August 26 & 0.95 & $<1.0$ \\
\hline W4 & September 29 & 1.1 & 1.0 \\
\hline W4 & October 28 & 1.3 & $<1.0$ \\
\hline W4 & November 30 & 1.5 & 2.0 \\
\hline W4 & December 23 & 1.3 & $<1.0$ \\
\hline W7 & March 25 & 6.6 & 7.0 \\
\hline W7 & April 22 & 2.5 & 2.3 \\
\hline W7 & November 30 & 7.4 & 4.7 \\
\hline W7 & December 23 & 7.4 & 5.0 \\
\hline W8 & January 22 & 4.9 & 7.4 \\
\hline w8 & February 26 & 2.7 & 3.2 \\
\hline W8 & March 22 & 2.4 & 4.0 \\
\hline W8 & May 27 & 1.7 & 1.2 \\
\hline W8 & July 22 & 2.0 & 1.0 \\
\hline W8 & August 26 & 1.4 & 2.0 \\
\hline W8 & September 29 & 1.6 & 1.4 \\
\hline w8 & October 28 & 1.8 & $<1.0$ \\
\hline W8 & November 30 & 6.0 & 8.1 \\
\hline W8 & December 23 & 1.8 & 1.0 \\
\hline w9 & January 22 & 2.4 & 1.9 \\
\hline W9 & February 26 & 2.2 & 2.1 \\
\hline w9 & March 25 & 2.1 & 1.4 \\
\hline W9 & April 22 & 1.7 & 1.2 \\
\hline W9 & May 27 & 0.95 & 1.0 \\
\hline W9 & June 30 & 0.88 & 1.4 \\
\hline W9 & July 22 & 1.5 & 1.5 \\
\hline W9 & August 26 & 0.68 & $<1.0$ \\
\hline W9 & September 29 & 2.2 & $<1.0$ \\
\hline W9 & October 28 & 1.7 & 1.0 \\
\hline W9 & November 30 & 2.7 & 2.0 \\
\hline w9 & December 23 & 1.8 & 2.0 \\
\hline
\end{tabular}


Milk Sampling

\begin{tabular}{ccc}
\hline $\begin{array}{c}\text { Sampling } \\
\text { Date }\end{array}$ & $\begin{array}{c}\text { Concentration (pCi/L) } \\
\text { Fernald Site }\end{array}$ & \begin{tabular}{c} 
ODH \\
\hline March 25
\end{tabular} \\
\hline June 30 & 0.072 & $<1.0$ \\
\hline September 29 & 0.059 & $<1.0$ \\
\hline December 23 & 0.027 & $<1.0$ \\
\hline
\end{tabular}

(a) See figures 32 and 36 on pages 89 and 100 for locations.

(b) To obtain Bq/L, multiply $\mathrm{pCi} / \mathrm{L}$ by 0.037

(c) These wells are used for monitoring purposes only. 


\section{Chemical Release Information for 1993}

Among the information presented in the SER for the Fernald site are estimates on both radiological and nonradiological emissions to the environment. The information in this appendix includes chemical release estimates from the Superfund Amendments and Reauthorization Act of 1986 (SARA) 313 report for 1993 and a summary of emissions from the Boiler Plant during 1993. This summary includes the chemical name, type and quantity of release, major release sources, and the basis of estimate.

To estimate releases, the Fernald site used a method that followed guidelines defined by SARA 313. These estimates do not reflect actual measured emissions. Rather, the Fernald site estimated releases through material balance calculation, monitoring data, or engineering calculations.

In cases where quantitative monitoring data, inventory estimates, or emission factors were not readily available, release estimates were based on best engineering judgments. Information obtained from air permits, rate of operation, quantities used, and known treatment efficiencies were used to estimate quantities released into the environment. Typically, assumptions based on best engineering judgment were required in order to perform the calculations when all variables were not known.

Calculations for Boiler Plant emissions were based on published AP-42 emission factors and coal use and analysis records for the Fernald site during 1993.

The SARA 313 chemicals included in this appendix are a summary of the SARA Title III, Section 313 Report, required by SARA legislation. This legislation requires facilities to report any listed chemical manufactured or processed the previous year in excess of 25,000 pounds, or otherwise used in excess of 10,000 pounds. This report is submitted to USEPA and OEPA each year on July 1 for the previous calendar year and contains chemicals on USEPA's toxic substance list. 
Fernald Site Chemical Release Information for 1993

Section One: Summary of SARA 313 Report

\begin{tabular}{|c|c|c|c|c|}
\hline $\begin{array}{c}\text { Chemical } \\
\text { Name }\end{array}$ & $\begin{array}{c}\text { Type } \\
\text { of Release }\end{array}$ & $\begin{array}{c}\text { Quantity } \\
\text { Released (lb/kg) }\end{array}$ & $\begin{array}{l}\text { Release } \\
\text { Sources }\end{array}$ & $\begin{array}{c}\text { Basis } \\
\text { of Estimate }\end{array}$ \\
\hline \multirow[t]{3}{*}{ Methanol } & Air: fugitive & $860 / 390$ & $\begin{array}{l}\text { Chemical } \\
\text { Processing Aid }\end{array}$ & $\begin{array}{l}\text { Published } \\
\text { Emission Factors }\end{array}$ \\
\hline & Air: point source & $150 / 70$ & $\begin{array}{l}\text { Chemical } \\
\text { Processing Aid }\end{array}$ & $\begin{array}{l}\text { Published } \\
\text { Emission Factors }\end{array}$ \\
\hline & $\begin{array}{l}\text { Water: } \\
\text { Great Miami River }\end{array}$ & $1,700 / 770$ & $\begin{array}{l}\text { Chemical } \\
\text { Processing Aid }\end{array}$ & $\begin{array}{l}\text { Best Engineering } \\
\text { Judgment }\end{array}$ \\
\hline Sulfuric Acid & None & $25 / 11$ & Battery Spills & $\begin{array}{l}\text { Best Engineering } \\
\text { Judgment }\end{array}$ \\
\hline \multicolumn{5}{|c|}{ Section Two: Boiler Plant Emissions } \\
\hline $\begin{array}{l}\text { Chemical } \\
\text { Name }\end{array}$ & $\begin{array}{c}\text { Type } \\
\text { of Release }\end{array}$ & $\begin{array}{c}\text { Quantity } \\
\text { Released (lb/kg) }\end{array}$ & $\begin{array}{c}\text { Major Release } \\
\text { Sources }\end{array}$ & $\begin{array}{c}\text { Basis } \\
\text { of Estimate }\end{array}$ \\
\hline Particulates & $\begin{array}{l}\text { Air: } \\
\text { stack emissions }\end{array}$ & $36,000 / 16,000$ & $\begin{array}{l}\text { Fossil Fuels } \\
\text { Combustion }\end{array}$ & Stack Testing \\
\hline Sulfur Dioxide & $\begin{array}{l}\text { Air: } \\
\text { stack emissions }\end{array}$ & $630,000 / 290,000$ & $\begin{array}{l}\text { Fossil Fuels } \\
\text { Combustion }\end{array}$ & $\begin{array}{l}\text { AP-42 Emission } \\
\text { Factors (a) }\end{array}$ \\
\hline Nitrogen Oxide & $\begin{array}{l}\text { Air: } \\
\text { stack emissions }\end{array}$ & $336,000 / 152,000$ & $\begin{array}{l}\text { Fossil Fuels } \\
\text { Combustion }\end{array}$ & $\begin{array}{l}\text { AP-42 Emission } \\
\text { Factors }\end{array}$ \\
\hline Carbon Monoxide & $\begin{array}{l}\text { Air: } \\
\text { stack emissions }\end{array}$ & $120,000 / 54,000$ & $\begin{array}{l}\text { Fossil Fuels } \\
\text { Combustion }\end{array}$ & $\begin{array}{l}\text { AP-42 Emission } \\
\text { Factors }\end{array}$ \\
\hline $\begin{array}{l}\text { Non-methane } \\
\text { Volatile } \\
\text { Organic } \\
\text { Compounds }\end{array}$ & $\begin{array}{l}\text { Air: } \\
\text { stack emissions }\end{array}$ & $1,700 / 760$ & $\begin{array}{l}\text { Fossil Fuels } \\
\text { Combustion }\end{array}$ & $\begin{array}{l}\text { AP-42 Emission } \\
\text { Factors }\end{array}$ \\
\hline
\end{tabular}

(a) Calculations were based on AP-42 emission factors and 1993 Fernald site coal use and analysis recurds.

\section{Fernald Site Source Reduction Information for 1993}

Section One: Summary of SARA 313 Report

\begin{tabular}{c|c|c|c|c}
\hline $\begin{array}{c}\text { Chemical } \\
\text { Name }\end{array}$ & $\begin{array}{c}\text { Type } \\
\text { of Treatment }\end{array}$ & $\begin{array}{c}\text { Quantity } \\
(\mathbf{l b} / \mathbf{k g})\end{array}$ & $\begin{array}{c}\text { Treatment } \\
\text { Method }\end{array}$ & $\begin{array}{c}\text { Basis } \\
\text { of Estimate }\end{array}$ \\
\hline Methanol & Treated onsite & $78,000 / 35,000$ & Biological-Aerobic & $\begin{array}{l}\text { Best Engineering } \\
\text { Judgment }\end{array}$ \\
\hline
\end{tabular}




\section{References}

1 General Envirommental Protection Program, U.S. Department of Energy Order 5400.1. November 9, 1988.

2 Facemire, C.F., S.I. Guttman, D. R. Osborne, and R.H. Sperger, Biological and Ecological Site Characterization of the Feed Materials Production Center. Mami University, Oxford, Ohio, 1990).

3 Feed Materials Production Center, Fernald, Ohio, Remedial Imestigation Report for Operable Unit 4 Task 6 Report, Final Draft. U.S. Department of Energy. Oak Ridge Operations Office, October 1990.

4 GeoTrans, Inc., Preliminary Characterization of the Gromedwater Flow System Near the Feed Materials Production Center, (ireat Miami River Valley-Fill Aquifer. Fernald, Ohio, September 1985.

5 Speiker, A. M., Groundwater Hydrology and the Geology of the Lower (ireat Miami River Valley, Ohio, USCiS Professional Paper 605-A. 1968.

6 Dames and Moore, Gronndwater Study Task (' Report, June 1985.

7 FMPC Environmental Monitoring Section, 1990) (iroundwater Monitoring Anmual Report for the Fe'rnald Site, Draft, November 1991.

$8 \quad$ Rozelle, James L., Facsimile to T. R. Neyer, April 20, 1994.

9 Radiation Profection for the Public and the Enviromment, U.S. Department of Energy Order .5400.5. February 8. 1990.

10) International Commission on Radiological Protection, Annals of the ICRP. Recommendations of the International Commission on Radiological Protedtion, IC RP Publication Nos. 26/30, Parls 1, 2, 3, Pergamon Press, Oxford, NY, 1977, 1979, 1980, and 1981.

11 National Emission Standards for Hazardons Air Pollutants - Subpart H- National Emission Standards for Emissions of Radiomuclides other than Radon from DOE Facilities, Code of Federal Regulations, Title 40, Parts 61.9.3 and 61.94, Vol. 50), No. 2.5, February 1985.

12 National Interim Primary Drinking Water Regulations - Sulpart B - Maximum Comtaminamt Levels, Code of Federal Regulations. Title 40, Part 141. July I, 1984.

1.3 Maynard and Hodge, 1949, as referenced in FR, Vollume .56, No. 1.38, p. 33(1)77, July 18,1991 .

14 National Council on Radiation Protection and Measurements, Lomizing Radiation Exposure of the Population of the United State's, NCRP-9.3, 1987. 
15 Upton, Arthur C., The Biological Eiffects of Low-Level Ionizing Radiation, Scientific American, pp. 41-49, February 1982.

16 The American Nuclear Society and the International Atomic Energy Agency. Radiation-A Fact of Life, 1979.

17 Eisenbud, Merril, Envirommental Rudioactivity, 2nd ed., New York. Academic Press, 1973.

18 Murray, Raymond L., Understanding Radionative Waste, 2nd ed., Columbus, Ohio, Battelle Press, 1983.

19 Kingman, Sharon, A Lot of Fuss About a Few Millisie'verts, New Scientist, May 15, 1986.

20) Marx, Jean L., Lower Radiation Effect Found, Science, September 9, 1988.

21 National Research Council, Health Effects of Exposure to Low Levels of Ionizing Radiation, BEIR V, National Academy Press, 1990.

22 U.S. Department of Energy. Office of Environmental Guidance, "Hazardous" Terminolog!, January 1991.

23 U.S. Department of Energy, CERCLA/RCRA Background Soil Study, Fernald Environmental Management Project. Final, March 199.3.

24 U.S. Environmental Protection Agency, Method for Estimating Fugitive Particulate Emissions from Hazardous Waste Sites, EPA/6()/2-87/(066, PB87-2.3220.3, Cincinnati, Ohio, August 1987.

25 Myrich. T. E., B. A. Berven. and F. F. Haywood, Determination of Cencentrations of Selected Radiomuclides in. Surface Soril in the U.S., Health Physics. 45.3, 1983.

26 Radiological Effluent Monitoring and Emvirommental Surveillance, Code of Federal Regulations, Title 10. Part 8.34, Draft. January 10, 1991.

27 Ohio Environmental Protection Agency. Measurements and Procedures, Lanis and Regulations, Regulation No. 3745-1804. November 1984.

28 Miller, Michael C., Electrofishing Survey of the (ireat Miami River, August 20 - 23, Draft, University of Cincinnati Department of Biological Sciences, November 1992.

29 Bardo, R. W., Great Miami River Fish Data for 1993, M:ESH:ESHA:ESA:94-()(46, May 4, 1994.

30) Fernald Environmental Restoration Management Corporation, 1993 RCRA Annucal Report, Volume I, April 1994.

31 Hem, John, D., Study and Interpretation of the Chemical Characteristics of Natural Water, Geological Survey. Water Supply Paper 1473, 1982. 
33 Secondary Maximum Contaminamt Levels, Code of Federal Regulations. Title 40, Part 14.3, July 1. 1988.

34 Controls for Environmental Pollution. Inc.. Drinking Water Handbook, Santa Fe. New Mexico, 1988.

35 National Secondary Drinking Water Regulations. Code of Federal Regulations. Title 40. Part 14.3, July 1991.

36 Miller, Charles W., ed., Models and Parameters for Envirommental Radiological Asse'ssme'tts, Report DOE/TIC - 1/468, Oak Ridge National Laboratory, 1984.

37 U.S. Department of Energy, Interral Dose Comversion Factors for Calculation of Dose to the Public, DOE/EH-O(O7\%, July 1988.

38 National Council on Radiation Protection and Measurements, Evaluation of Occupational and Envirommental Exposures to Radon and Radom Daughters in the United States, NCRP - 78, 1984.

39 International Commission on Radiological Protection, Limits for Imtakes of Radionuclides b. Workers, ICRP-30, July 1978.

40) International Commission on Radiological Protection. Recommendations of the ICRP, ICRP-26. January 1977. 


\section{Glossary}

Activity the rate of disintegration, expressed as disintegrations per second (Becquerels) or in units of Curies (one Curie $=3.7 \times 10^{10}$ Becquerels).

ALARA a phrase and acronym (As Low As Reasonably Achievable) used to describe an approach to radiation exposure and emissions control or management whereby the exposures and resulting doses to the public are maintained as far below the specified limits as economic, technical, and practical considerations will permit.

Aliquot the fraction of a field sample taken for complete processing through an analytical procedure (a "laboratory sample" of a field sample).

Alpha Particle

Anion

Aquifer

Background Radiation

Backlog

Beta Particle

Billet

Biological Indicator

Blank

Calibration

Confidence Coefficient type of particulate radiation (identical to the nucleus of the helium atom) consisting of two protons and two neutrons.

the negatively charged atom in an ionic compound.

a body of rock that is sufficiently permeable fo conduct groundwater and to yield economically significant quantities of water to wells and springs.

the radiation in the natural environment, including cosmic rays and radiation from the naturally radioactive elements, both outside and inside the bodies of humans and animals.

onsite waste awaiting permitted treatment. storage, or disposal options.

type of particulate radiation emitted from the nucleus of an atom that has a mass and charge equal in magnitude to that of the electron.

machined ingots. During production times at the site, these billets were shipped to other DOE sites for use.

organisms that reveal the presence of pollution in an ecosystem. For instance, algal blooms indicate organically or nutrient enriched waters.

a sample of the carrying agent (gas, liquid, or solid) normally used to selectively measure a material of interest that is subjected to the usual analytical procedures process to establish a baseline or background value. This value is then used to adjust or correct the routine analytical results.

the adjustment of the system and the determination of system accuracy using known sources and instrument measurements. Adjustment of flow, temperature, humidity, or pressure gauges and the determination of system accuracy should be conducted using standard operating procedures and sources that are traceable to the National Institute of Standards and Technology.

the chance or probability, usually expressed as a percentage. that a confidence interval includes some defined parameter of a population. The confidence coefficients usually associated with confidence intervals are $90 \%, 95 \%$. and $99 \%$. For a given sample size, the width of the confidence interval increases as the confidence coefficient increases. 
Confidence Interval

Conservative Estimate

Contamination

Critical Organ

Critical Pathway

Curie (Ci) and Becquerel (Bq)

Daughter

Decay

Derby

Derived

Concentration Guideline

Dose

Drum Equivalent

Effluent Monitoring

Enrichment

Environmental Detection Limit

Exposure Pathway a value interval that has a designated probability (the confidence coefficient) of including some defined parameter of the population.

used frequently in environmental monitoring and dose calculation, it is based on assumptions about an exposure situation that should result in the highest estimate of a dose.

any substance or material that is somewhere it is not supposed to be.

the human organ or tissue receiving the largest fraction of a specified dose limit. the specific route of transfer of radionuclides from one environmental component to another that results in the greatest fraction of an applicable dose limit to a population group or an individual's whole body, organ, or tissue.

are units of radioactivity that measure the rate of spontaneous, energy-emitting transformations in the nuclei of atoms. One Curie equals 37 billion transformations per second. One Becquerel equals one transformation per second. One Curie ( 37 billion $\mathrm{Bq}$ ) of natural uranium is equivalent to a mass of about $1,50)$ kilograms $(3,30()$ pounds).

a nucleus that results from radioactive decay; also, progeny.

the disintegration process of an atomic nucleus.

the main product of the former site processing of uranium metal.

the concentration of a radionuclide in air or water that, under conditions of continuous exposure for one year by one exposure mode (for example, drinking water or breathing the air) that would result in either an effective dose equivalent of $0.1 \mathrm{rem}(1 \mathrm{mSv}$ ) or a dose equivalent of $5 \mathrm{rem}(50 \mathrm{mSv}$ ) to any tissue, including skin and the lens of the eye.

quantity of radiation absorbed in tissue.

the number of 55 -gallon drums that it would take to contain a given volume of waste.

the collection and analysis of samples or measurements of liquid, gaseous, or airborne effluents for the purpose of characterizing and quantifying contaminants and process stream characteristics, assessing radiation exposures to members of the public, and demonstrating compliance with applicable standards.

a process to increase the percentage of a desired isotope such as uranium--235.

the lowest concentration at which a radionuclide in an environmental medium can be unambiguously distinguished for a given confidence level using a particular combination of sampling and measurement procedures, sample volume, analytical detection limit, and processing procedure.

a route by which materials could travel between the point of release and the point of delivery of a radiation or chemical dose to a person. 
Fission the splitting of a heavy nucleus into two approximately equal parts, accompanied by the release of large amounts of energy and generally one or more neutrons.

Flux Rate a measurement of the emission rate of radon.

Fugitive Dust dust that did not flow through a production stack. This includes materials such as dust from the waste storage areas, administration areas, and dust that originated from construction activities.

Gamma Ray type of electromagnetic radiation of discreet energy emitted during radioactive decay of many radioactive elements.

Glacial Till the mix of clay, silt, sand, gravel, and boulders deposited by the glaciers.

Half Life the length of time for half the atoms of a given radioactive substance to decay.

Hydrology the study of the properties, distribution, and circulation of water through the local environment.

ICRP International Commission on Radiological Protection is an organization founded in 1928 and whose function is to recommend international standards for radiation protection.

Ingot remelted derbies and uranium scrap-metal from the former site production process. They varied in weight, size, and shape according to how they were used at this and other DOE sites.

Ionization removal of electrons from an atom, such as by means of interaction with radiation.

Isotope atoms with the same atomic number but different mass number. Isotopes usually have the same chemical properties, but could have very different radiological properties (such as half-life and type of radiation emitted).

Less than Detectable refers to a measurement or calculated concentration that is not statistically different from the associated background or control value at at selected confidence level.

Lithology the study, classification, and mapping of rocks and rock formations.

Lower Limit of Detection the smallest amount of a contaminant that can be distinguished in a sample by a given measurement procedure at a given confidence level.

Minimum Detection Level the minimum amount of the constituent or species of interest that can be observed by an analytical instrument and distinguished from background and instrument noise with a specified degree of probability.

Mixed Wastes hazardous waste that has been contaminated with low-level radioactive materials.

Monitor 1) to measure certain constituents or parameters in an effluent stream continuously or at a frequency that permits a representative estimate of the amount over a specified interval of time;

2) the instrument or device used in monitoring. 
NLRP National Council on Radiation Protection and Measurements chartered by Congress in 1914 and charged with developing radiation protection standards.

Nuclide a general term applicable to all atomic forms of the elements, including isotopes.

Null Allele an inactive group of genes.

Occurrence any sudden release or sustained deviation from a regulated or planned performance of an operation that has environmental protection and compliance significance.

Onsite refers to the area within the boundaries of a facility or site that is or can be controlled with respect to access by the general public.

Opacity how much light is blocked by particulates present in stack emissions.

Operable Unit a discrete action that comprises an incremental step toward comprehensively addressing site problems. Operable units may address geographical portions of a site. specific site problems, or initial phases of an action performed over time, or any actions that are concurrent but located in different parts of the site.

Overburden the soil. rock. and other naturally occurring material overlying the bedrock.

Overpacking the act of placing a deteriorating drum inside a new. larger drum to prevent further deterioration or the possible release of contaminants during storage.

Parent Material

a radionuclide that produces a specific "daughter" product either directly or as a later result of radioactive decay or disintegration.

Person-rem a collective dose to a population group. For example, a dose of one rem to ten people results in a collective dose of ten person-rem.

Plate Out a thermal. electrical. chemical. or mechanical action that results in a loss of material hy deposition on surfaces.

Point Source the single defined point (origin) of a release such as a stack, vent, pipe, or other discernable conveyance.

Positive Interference

Potable Water

Radioactive Emissions

Radioactive Material

Radioisotope

Radionuclide

Random Samples during sampling analysis. this produces a result that indicates the presence of a radionuclide when, in fact, there is very little or no presence of this radionuclide in the sample.

water that is suitable for consumptive purposes.

releases of radioactive materials to the environment.

refers to any material or combination of materials that spontaneously emits ionizing radiation.

a radioactive isotope.

refers 10 a radioactive nuclide. There are several hundred known radionuclides, hoth artificially produced and naturally occurring: radionuclides are characterized by the number of neutrons and protons in an atom's nucleus and their characteristic decay processes.

samples that are obtained in such a manner that all items or members of the lot. or population. have an equal chance of heing selected in the sample. 
Remedial Action

Removal Action

Representative Sample

Roentgen Equivalent Man (rem) and Sievert (Sv)

Roentgen $(\mathbf{R})$ and Coulombs per kilogram $(\mathrm{C} / \mathrm{kg})$

Sample

Sampling

Scintillation Cell

Sensitivity

Site Characterization

Spiked Sample

Terrace Remnants

Thermoluminescent Dosimeter

Tolerance Limits

Transuranic

Wetland an action that is consistent with the final remedy following a formal examination of the nature and extent of the release, or threat of release, assessment of the risk, and selections of the final remedy based on an evaluation of possible alternatives (RI/FS process).

any necessary action to abate an immediate threat to health and the environment, including actions necessary to monitor, assess, or evaluate the threat.

a sample taken to depict the characteristics of a lot or population as accurately and precisely as possible. A representative sample may be a "random sample" or a "stratified sample" depending upon the objective of the sampling and the characteristics of the conceptual population.

units of dose which account for the relative biological damage due to the type of radiation involved. One rem equals $0.01 \mathrm{~Sv}$.

units of exposure to radioactivity. One $\mathrm{R}$ equals $2.6 \times 10^{-4} \mathrm{C} / \mathrm{kg}$, and is a measure of the ionization in air due to a source of radioactivity.

1) a subset or group of objects selected from a larger set. called the population:

2) an extracted portion of a subset of an effluent stream or environmental medium.

the extraction of a prescribed portion of an effluent stream or of an environmental medium for purposes of inspection and/or analysis.

produces a light pulse when struck by an alpha particle and is able to be counted.

the minimum amount of a radionuclide or other material of interest that can repeatedly be detected by an instrument. system. or procedure.

designed to provide the information needed to identify site hazards and to select worker protection methods.

a normal sample of material (gas, liquid. or solid) to which a known amount of some substance of interest is added. Spiked samples are used to check on the performance of a routine analysis or the recovery efficiency of an analytical method.

land that stands higher than its surroundings due to crosion.

used to monitor the amount of radiation to which it has been exposed.

a particular type of contidence limit used frequently in quality control work. where the limits apply to a pereentage of the individual values of the population.

an element with an atomic number greater than uranium.

areas covered or saturated with water for enough time to support water-loving vegetation. Typical wetlands include swamps. marshes. and hogs. 


\section{SER Distribution List}

\section{External Distribution}

Department of Energy, Fernald Field Office - 250 copies

This report is distributed widely by the Department of Energy to local, state, and federal agencies, Congress, the public, and the media.

Internal Distribution

Environmental Monitoring - 894 copies

Public Affairs - 50 copies

Library - 6 copies

Public Environmental Information Center - 100 copies 

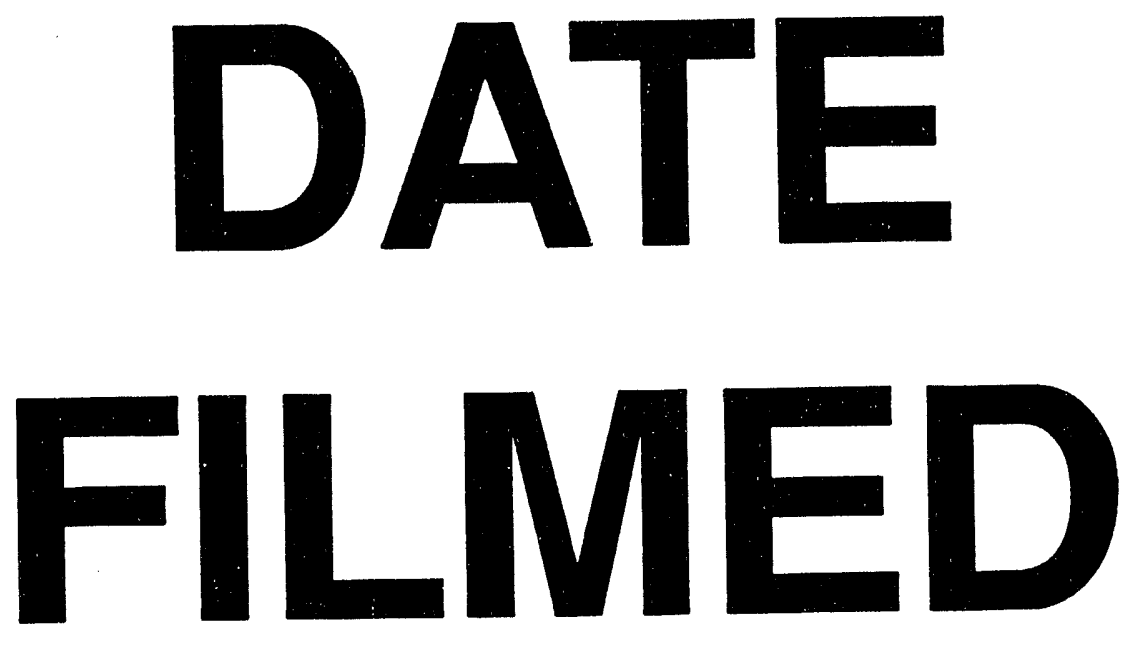

$10 / 4 / 94$
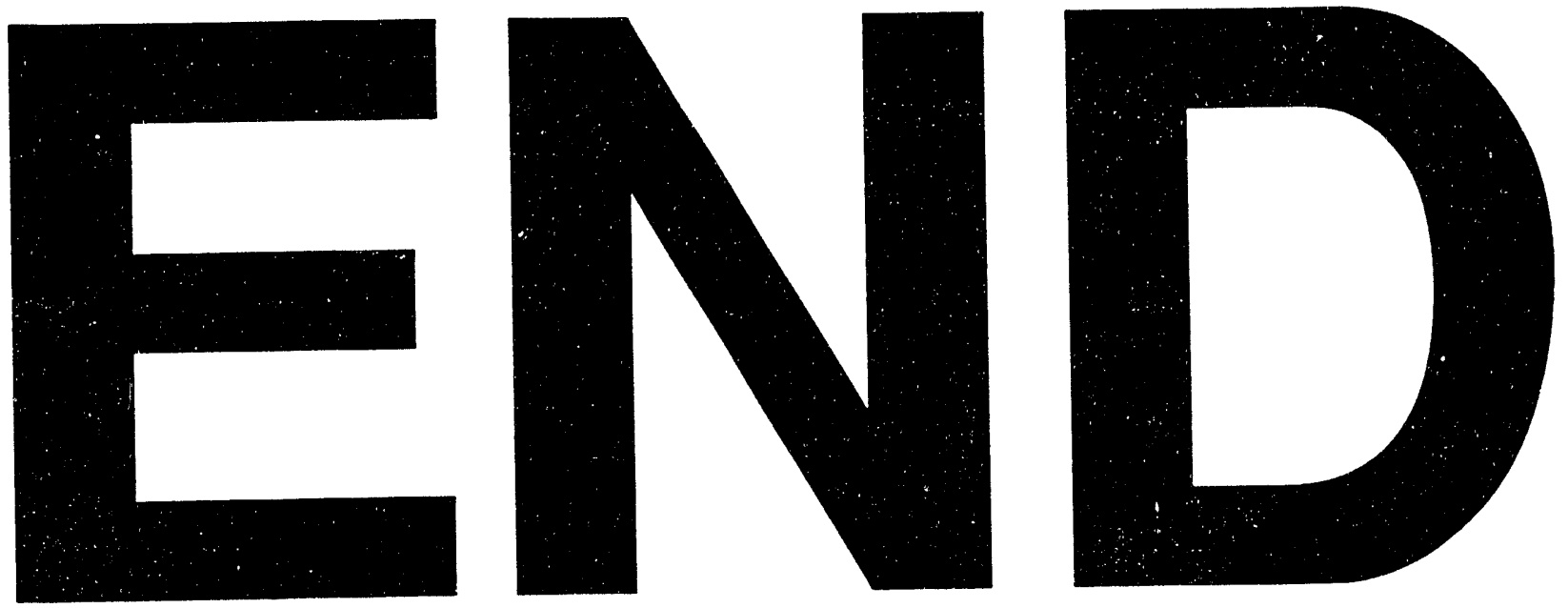
